Rebeka de Oliveira Pepino

Clonagem, expressão, purificação e caracterização biofísica da proteína quinase dependente de ciclina 11 obtida pela expressão em Escherichia coli

São Carlos

2021 
Rebeka de Oliveira Pepino

\title{
Clonagem, expressão, purificação e caracterização biofísica da proteína quinase dependente de ciclina 11 obtida pela expressão em Escherichia coli
}

\author{
Tese de doutorado desenvolvido no \\ Instituto de Química de São Carlos, \\ da Universidade de São Paulo para a \\ obtenção do título de Doutor em \\ Química.
}

Área de Concentração: Química Orgânica e Biológica.

Orientadora: Prof ${ }^{\mathrm{a}}$. Dr ${ }^{\mathrm{a}}$. Fernanda Canduri.

\section{Exemplar revisado}

$O$ exemplar original encontra-se em acervo reservado na Biblioteca do IQSC-USP

São Carlos 

Autorizo a reprodução e divulgação total ou parcial deste trabalho, por qualquer meio convencional ou eletrônico para fins de estudo e pesquisa, desde que citada a fonte.

\section{Assinatura: \\ Data:}

\section{Pepino, Rebeka de Oliveira}

Clonagem, expressão, purificação e caracterização biofísica da proteína quinase dependente de ciclina 11 obtida pela expressão em Escherichia coli / Rebeka de Oliveira Pepino. - São Carlos, 2021.

$144 \mathrm{f}$.

Tese (Doutorado em Química Orgânica e Biológica) - Instituto de Química de São Carlos / Universidade de São Paulo, 2021.

Orientadora: Profa. Dra. Fernanda Canduri

1. CDK11. 2. Clonagem. 3. Expressão. 4. Escherichia coli. 5. Ensaios biofísicos. I. Título. 


\section{AGRADECIMENTOS}

A Deus por tudo que proporciona na minha vida.

A todos os meus familiares, pelo amor, compreensão, apoio, amizade e incentivo. Em especial ao meu filho Gabriel, ao meu filho Filipe, ao meu marido Luis, aos meus pais, aos meus sogros e aos meus irmãos.

A Universidade de São Paulo e ao Instituto de Química de São Carlos pela oportunidade concedida.

A Professora Dra. Fernanda Canduri pela orientação, compreensão, incentivo e por toda a ajuda.

Aos amigos do Laboratório e do IQSC pelos momentos de descontração, amizade, ajuda e incentivo, em especial às amigas Fernanda, Diandra, Jessyka, Tatiane, Buana e Célia.

Ao Laboratório de Biologia Molecular do grupo de Cristalografia do Instituto de Física de São Carlos pelo sequenciamento das amostras.

A todos do Laboratório do Grupo de Química Medicinal (NEQUIMED) em especial aos Professores Dr. Carlos Alberto Montanari e Dr. Andrei Leitão e a técnica Fabiana Rosini.

Ao Professor Dr. Alessandro Silva Nascimento, do Grupo de Biotecnologia Molecular do IFSC/USP, pelo auxílio na modelagem e dinâmica molecular.

A Professora Dra. Fernanda Andreia Rosa, da Universidade Estadual de Maringá (UEM) pelos inibidores.

Ao pessoal do CAQI pelas análises realizadas, em especial aos técnicos, Aldimar Tadeu Jesuino Constante, André Luiz Tognon e Luiz Antonio Abondancia.

Ao pessoal do serviço de pós-graduação do IQSC.

Ao pessoal da biblioteca do IQSC.

Ao CNPQ e a CAPES pela bolsa concedida e a FAPESP pelo financiamento dos projetos do laboratório.

E a todos que contribuíram na elaboração deste trabalho. 


\section{RESUMO}

A superexpressão e hiperativação da CDK11 desempenham papéis importantes no crescimento e proliferação de vários tipos de câncer. O silenciamento da CDK11 é capaz de inibir a proliferação celular e induzir a apoptose em células de câncer de mama, mieloma múltiplo, osteossarcoma e lipossarcoma. Nesse cenário, a CDK11 tornou-se um alvo terapêutico promissor; no entanto, faltam informações estruturais para 0 desenvolvimento de inibidores de CDK11, uma vez que esta proteína não tem estrutura cristalográfica resolvida até o momento. O domínio quinase de CDK11 (CDK11 selecionado a partir de corpos de inclusão foi redobrado e purificado usando cromatografia de afinidade ao níquel. O rendimento final de CDK $11 \Delta$ foi de $30 \mathrm{mg} / \mathrm{L}$ de meio de cultura, com alta pureza. A proteína foi analisada por espectroscopia de dicroísmo circular e espectrofluorimetria. A análise de espectros de dicroísmo circular estimou $31 \%$ de hélices $\alpha$, temperatura de desnaturação de $62{ }^{\circ} \mathrm{C}$ e estabilidade de armazenamento por até 70 dias a $4{ }^{\circ} \mathrm{C}$. A espectrofluorimetria confirmou a interação da proteína com seu ligante natural ATP, e também com a roscovitina, um conhecido inibidor de outras CDKs; os valores de $\mathrm{K}_{\mathrm{d}}$ medidos foram $4 \mu \mathrm{M}$ e $16 \mathrm{nM}$, para ATP e roscovitina, respectivamente, o que indica o segundo como um potencial inibidor de CDK11. Na análise bioinformática, os modelos construídos para o complexo CDK11 1 -ATP indicam que Lys134, Lys37, Thr18 e Asn137 são resíduos determinantes na formação de ligações de hidrogênio com ATP, e para o complexo CDK11 1 -roscovitina, as ligações de hidrogênio envolvem a cadeia principal de resíduos Val89 e Glu90. O número de contatos Van Der Walls encontrados na CDK11 são semelhantes ao valor encontrado para a CDK2, sugerindo que a CDK11, assim como a CDK2, tem o potencial de ser inibida pela roscovitina. O estudo das interações com esses ligantes contribuirá para o desenvolvimento de futuros inibidores promissores para CDK11. Os valores das constantes de dissociação $\left(\mathrm{K}_{\mathrm{d}}\right)$ para CDK11 $\Delta$ com os inibidores $3 \mathrm{a}, 3 \mathrm{~b}$ e $3 \mathrm{f}$, foram de $409 \mu \mathrm{M}, 35 \mu \mathrm{M}$ e de $5 \mu \mathrm{M}$, respectivamente, indicando interações fraca (3a) e moderadas ( $3 b$ e $3 f)$.

Palavras-chave: CDK11; Clonagem; Expressão; Escherichia coli; Ensaios biofísicos; Roscovitina 


\section{ABSTRACT}

Overexpression and hyperactivity of CDK11 play important roles in the growth and proliferation of several types of cancer. The CDK11 silencing is able to inhibit cell proliferation and induce apoptosis in breast cancer, multiple myeloma, osteosarcoma and liposarcoma cells. In this scenario, CDK11 became a promising therapeutic target; however, structural information is lacking for CDK11 inhibitors' development, since this protein has no crystallographic structure solved until this moment. The kinase domain of CDK11 (CDK11 $\Delta$ ) selected from inclusion bodies was refolded and purified using Nickel affinity chromatography. The final yield of CDK $11 \Delta$ was $30 \mathrm{mg} / \mathrm{L}$ of culture medium with high purity. The protein was analyzed by circular dichroism spectroscopy and spectrofluorimetry. Circular dichroism spectra analysis estimated $31 \% \quad \alpha$-helix, denaturation temperature of $62^{\circ} \mathrm{C}$ and storage stability up to 70 days at $4^{\circ} \mathrm{C}$. Spectrofluorimetry confirmed the protein interaction with its natural ligand ATP, and also with roscovitine, a known inhibitor of other CDKs; the measured $K_{d}$ values were $4 \mu \mathrm{M}$ and $16 \mathrm{nM}$, for ATP and roscovitine respectively, which indicates the second as a potential CDK11 inhibitor. In bioinformatic analysis, models built for the CDK11 1 -ATP complex indicate that Lys134, Lys37, Thr18 and Asn137 are determinant residues in making hydrogen bonds with ATP, and for the CDK11 1 -roscovitine complex, the hydrogen bonds involve the main chain of residues Val89 and Glu90. The number of Van Der Walls contacts found in CDK11 are similar to the value found for CDK2, suggesting that CDK11, as well as CDK2, has the potential to be inhibited by roscovitine. The study of interactions with these ligands will contribute to the development of future promising inhibitors for CDK11. The measured $\mathrm{K}_{d}$ values for CDK11 $1 \Delta$ with inhibitors $3 \mathrm{a}, 3 \mathrm{~b}$ and $3 \mathrm{f}$ were $409 \mu \mathrm{M}, 35 \mu \mathrm{M}$ and $5 \mu \mathrm{M}$, respectively, indicating weak (3a) and moderate ( $3 \mathrm{~b}$ and 3f) interactions.

Keywords: CDK11; Cloning; Expression; Escherichia coli; Biophysical assays; Roscovitine 


\section{LISTA DE FIGURAS}

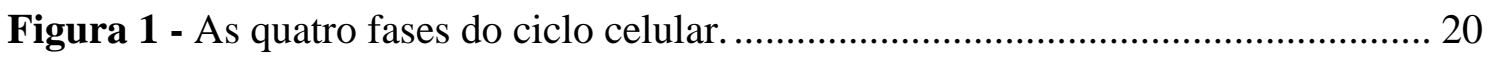

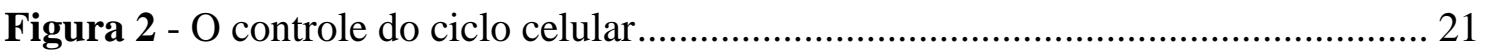

Figura 3 - Representação dos processos de fosforilação e desfosforilação .................... 22

Figura 4 - Relação evolutiva entre as CDKs e as ciclinas necessárias para sua ativação. Domínio quinase (verde), domínios ricos em arginina/serina (rosa); ácido glutâmico (azul), glutamina (amarelo) e prolina (vermelho). Para a CDK11 são mostradas as isoformas p58 e p110.

Figura 5 - Ativação das CDKs. (A) CDK sem ciclina - seu sítio ativo fica bloqueado (B) CDK ligada a ciclina - a alça $\mathrm{T}$ se afasta e a CDK pode ser fosforilada (C) CDK após fosforilação pela CAK - alteração conformacional que a ativa completamente.... 24

Figura 6 - Ativação da CDK2. (A) CDK2 sem ciclina (código PDB: 1HCK) - sítio ativo bloqueado pela alça $\mathrm{T}$, que obstrui o sítio de ligação para os substratos proteicos (B) CDK2 ligada a ciclina (código PDB: 1FIN) - a alça T se afasta e a hélice C é reorientada trazendo o resíduo Glu51 para o sítio ativo. (C) CDK2 após fosforilação da Thr160 na laça T (código PDB: 1JST) - produz resíduo negativamente carregado estabilizado ao interagir com três resíduos de Arg...................................................... 26

Figura 7- Estrutura do (A) Palbociclib (B) Ribociclib e (C) Ademaciclib ................... 27

Figura 8 - Fosforilação da Rb por CDKs.................................................................. 28

Figura 9 - Diagrama esquemático do comprimento total da CDK11 ........................... 30

Figura 10 - Elementos de estrutura secundária do monômero da CDK2 (código PDB: 1hck, resolução 1,90 ̊) ATP (em hastes e esferas), N-terminal rico em fitas $\beta$ (cinza), a alça rica em glicina (verde), $C$ - terminal rico em hélices $\alpha$ (rosa), hélice $C$, de sequência PSTAIRE (amarelo) e segmento de ativação ou alça T (azul).

Figura 11 - Processos celulares em que as isoformas de CDK11p110 atuam. - (I) Fosforilação da RNAPII CTD. (II) Associação entre o núcleo do complexo mediador e seu módulo de quinase (III) Na fosforilação de fatores de splicing. ............................. 33

Figura 12 - Autofosforilação e dimerização da CDK11p58 ....................................... 34

Figura 13 - Clivagem proteolítica da CDK11p110 em CDK11p46 e CDK11p60 no núcleo e atuação da CDK11p46 e da CDK11p60 no citoplasma.

Figura 14 - Estudos da CDK11 em câncer de cólon, cervical, leucemia mieloide aguda e mieloma múltiplo.

Figura 15 - Diagrama esquemático das diversas funções exercidas pela CDK11 ........ 40

Figura 16 - Construções usadas para introduzir a mutação $G \rightarrow S$ (glicina para serina) indicada em vermelho em xDFG antes (CDK11B) e após mutação (ssODN) mediado por CRISPR. Local da clivagem de Cas9 (seta amarela) e mutações silenciosas (destacadas em azul)

Figura 17- Alinhamento das CDKs, em azul, a posição do resíduo de glicina nas CDKs11A e B, diferente das demais CDKs. Em vermelho destaca-se o loop T.

Figura 18 - Análise da cadeia polipeptídica da CDK11 utilizando o PSIPRED........... 44

Figura 19 - Análise de códons raros para expressão de CDK11 1 em E. coli. 45 
Figura 20 - Primers desenhados para amplificação do cDNA da CDK11 $\Delta$.

Figura 21 - Sequência do cDNA da CDK11 com os sítios da NcoI e XhoI nas extremidades 5' e 3', respectivamente. A sequência referente a cauda de histidina e o códon de terminação aparecem ao final da sequência.

Figura 22 - Alinhamento de sequências da CDK11 em CDK11 $\Delta$ evidenciando os domínios RE (em laranja) domínio poli E (em azul) e o domínio quinase (Gly419Phe723) (em vermelho).

Figura 23. Diagrama esquemático dos processos de indução, lise, reenovelamento e purificação da CDK11

Figura 24. Espectros associados aos vários tipos de estrutura. .................................... 57

Figura 25. Diagrama de Jablonski

Figura 26 - Alinhamento de sequências da CDK11 em CDK11 $\Delta$ evidenciando o domínio quinase (Gly416-Phe720) em vermelho..

Figura 27 - Representação da técnica da gota suspensa.

Figura 28 - Reação de PCR utilizando um gradiente de temperatura na amplificação do cDNA da CDK11 $\Delta(932 \mathrm{pb})$, em vermelho destaca-se a melhor temperatura escolhida para o anelamento $\left(67,3^{\circ} \mathrm{C}\right)$.

Figura 29 - Reação de PCR das 6 colônias selecionadas após digestão, ligação e transformação. Em vermelho destaca-se as colônias que continham o recombinante... 71

Figura 30 - Análise do sequenciamento após alinhamento no programa MultiAlin. Em vermelho destacam-se as regiões idênticas entre a CDK11 $\Delta$ e o resultado do sequenciamento utilizando os primers direto e reverso, já em azul as regiões idênticas apenas entre duas sequências. As regiões circuladas em preto indicam os códons de início e de fim.

Figura 31 - (A) Gel de eletroforese com os resultados da indução, lise, reenovelamento e purificação da CDK11 . M - marcador; 5s - sobrenadante após 5horas de indução; L1, L2 e L3 - lavagens do pellet feitas após a lise; 5p - pellet após 5 horas de indução e após lavagens; SDSs - sobrenadante após reenovelamento; I - impurezas (primeiro pico após aplicação da amostra SDSs na coluna de Níquel) e CDK11 - proteína de interesse (segundo pico após aplicação da amostra SDSs na coluna e Níquel). A proteína purificada está destacada em vermelho. (B) Gel nativo em que M refere-se ao marcador e CDK11 $\Delta$ refere-se à proteína de interesse purificada (destacada em vermelho). ....... 74

Figura 32 - Cromatograma obtido na purificação da CDK11 $\Delta$ (amostra SDSs), utilizando a resina IMAC (GE HealthCare).

Figura 33 - Espectro de dicroísmo circular para a CDK11 a 0,13 mg/mL em tampão Tris-HCl $20 \mathrm{mM}, \mathrm{NaCl} 50 \mathrm{mM}$, glicerol a 5\% (v/v), $\beta$-mercaptoetanol $10 \mathrm{mM}$ e pH 7,4 diluído 20x

Figura 34 - (A) Avaliação da estabilidade de armazenamento a $4{ }^{\circ} \mathrm{C}$ após 0,25 e 70 dias de CDK11 $1 \Delta$ por dicroísmo circular (B) CDK11 $\Delta$ de gel nativo após 70 dias. Uma única banda é observada.

Figura 35 - Espectro de dicroísmo circular para a CDK11 $\Delta$ utilizando diferentes concentrações da proteína em tampão Tris- $\mathrm{HCl} 20 \mathrm{mM}, \mathrm{NaCl} 50 \mathrm{mM}$, glicerol a $5 \%$ $(\mathrm{v} / \mathrm{v}), 10 \mathrm{mM} \beta$-mercaptoetanol e $\mathrm{pH}$ 7,4 diluído 20x. 
Figura 36 - Avaliação da estabilidade térmica de CDK11 1 por dicroísmo circular em $222 \mathrm{~nm}$. CDK11 a 0,13 mg/mL em tampão Tris-HCl $20 \mathrm{mM}, \mathrm{NaCl} 50 \mathrm{mM}$, glicerol a $5 \%(\mathrm{v} / \mathrm{v}), 10 \mathrm{mM} \beta$-mercaptoetanol e $\mathrm{pH} 7,4$ diluido $20 \mathrm{x}$. A temperatura de transição Tm foi de $62{ }^{\circ} \mathrm{C}$, obtida por regressão sigmoidal

Figura 37 - Avaliação da estabilidade térmica de CDK11 1 por dicroísmo circular em diferentes temperaturas.

Figura 38 - Espectro de emissão de fluorescência para CDK11 $\Delta$ frente a diferentes concentrações de ureia (de $0 \mathrm{M}$ a $6 \mathrm{M}$ ).

Figura 39 - Modelo da CDK11 (cinza) após inserção do ligante ATP (verde) onde em (A) destaca-se os triptofanos em vermelho e em (B) as tirosinas em azul.

Figura 40 - Espectro de emissão de fluorescência para CDK11 $\Delta$ frente a diferentes concentrações de ATP.

Figura 41 - Gráficos típicos para as supressões (A) colisional e (B) estática (C) estática e colisional.

Figura 42 - Gráfico $\mathrm{F}_{0} / \mathrm{F}$ versus [Q] para a CDK11 $\Delta$ em função da concentração de ATP.

Figura 43 - Gráfico $\log \left(\mathrm{F}_{0}-\mathrm{F} / \mathrm{F}\right)$ versus $\log [\mathrm{ATP}]$ para a CDK11 $\Delta$ e seu respectivo ajuste linear

Figura 44 - Gráfico $F_{0} / F$ versus [Q] para a CDK11 $\Delta$ em função da concentração de roscovitina.

Figura 45 - Gráfico $\log \left(\mathrm{F}_{0}-\mathrm{F} / \mathrm{F}\right)$ versus $\log [$ roscovitina $]$ para a $\mathrm{CDK} 11 \Delta$ e seu respectivo ajuste linear

Figura 46 - Sobreposição dos modelos gerados (A) em base de CDKs com ciclina. Ciano: código PDB 5efq - CDK13, roxa: código PDB 5acb - CDK12, amarela: código PDB 4ogr - CDK9 e verde: código PDB 1vyw - CDK2. (B) em base de CDKs sem ciclina, ciano: código PDB 6gu7 (CDK1), roxa: código PDB 5g6v (CDK16), amarela: código PDB 1ua2 (CDK7) e verde: código PDB 5osm (CDK2). Em vermelho destacase o loop T, que varia sua conformação quando a CDK está ou não associada a ciclina, em A, conformação aberta e em B conformação fechada.

Figura 47 - Modelagem molecular comparativa da CDK11 a partir da CDK2 (código PDB: 5osm)

Figura 48 - Sobreposição dos modelos gerados pelo programa I-TASSER. Modelo 1 (verde), modelo 2 (ciano) e modelo 3 (roxo). Em vermelho destaca-se o loop T em conformação aberta

Figura 49 - Perfil de energia resíduo-por-resíduo para os modelos gerados no MODELLER

Figura 50 - Modelagem molecular da CDK11 $\Delta$ com ATP, $\mathrm{Mg}^{2+}$ e as moléculas de água de interação.

Figura 51 - Gráfico do Ramachandran para o modelo escolhido da CDK11 $\Delta$ com ATP

Figura 52 - Gráfico de energia das interações da CDK11 $\Delta$ com ATP durante a dinâmica. 
Figura 53 - Gráfico de energia das interações dos principais resíduos de aminoácidos da CDK11 $\Delta$ com ATP durante a dinâmica.

Figura 54 - Interações do ATP com as cadeias laterais dos resíduos de aminoácidos Lys37 e Lys 134 da CDK11 1 .

Figura 55 - Flexibilidade do sistema proteína-ligante ao longo dos 200ns de simulação. Amarelo (Frame 1) Pink (Frame 7500) Azul (Frame 10000) Rosa claro (Frame 12500) Verde (Frame 15000) Laranja (Frame 20000).

Figura 56 - Flexibilidade do ligante ao longo dos 200ns de simulação. Amarelo (Frame 1) Pink (Frame 7500) Azul (Frame 10000) Rosa claro (Frame 12500) Verde (Frame 15000) Laranja (Frame 20000)......

Figura 57 - Flexibilidade da proteína ao longo dos 200ns de simulação. Amarelo (Frame 1) Pink (Frame 7500) Azul (Frame 10000) Rosa claro (Frame 12500) Verde (Frame 15000) Laranja (Frame 20000).

Figura 58 - Interações do ATP com a cadeia principal dos resíduos de aminoácidos da (A) $\mathrm{CDK} 11 \Delta$ (B) CDK2

Figura 59 - Alinhamento da região que se liga ao ATP da CDK2 e da CDK11

Destacado em azul os resíduos analisados.

Figura 60 - Interações do ATP com a cadeia lateral dos resíduos de aminoácidos Lys37 e Glu15 da CDK11 $\Delta$ sem utilizar a molécula de água.

Figura 61 - Interações do ATP com a cadeia lateral dos resíduos de aminoácidos Asn137 e Lys134 da CDK11 $\Delta$ ligando-se com as águas 310 e 316. Asp92 e Thr18 não mostram interação no modelo gerado, antes da dinâmica.

Figura 62 - Interações do ATP com a cadeia lateral dos resíduos de aminoácidos Lys33 e Asp86 da CDK2 sem utilizar a água.

Figura 63 - Interações do ATP com a cadeia lateral dos resíduos de aminoácidos Asn132 e Lys129 da CDK2 ligando-se com as águas 2205 e 2094. Thr14 não mostra interação de hidrogênio.

Figura 64 - Modelagem molecular da CDK11 $\Delta$ com roscovitina............................... 106

Figura 65 - Interações da Roscovitina com a cadeia principal dos resíduos de ........... 107

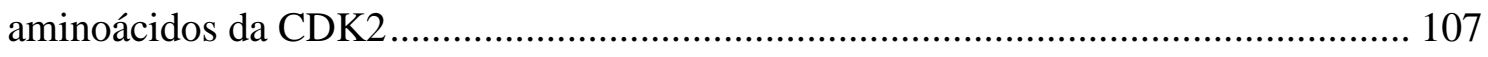

Figura 66 - Interações da Roscovitina com a cadeia principal dos resíduos de aminoácidos da CDK11

Figura 67 - Sobreposição da estrutura da CDK2 (cinza) com o ATP (amarelo) (código PDB 1qmz) com a estrutura da CDK2 (azul) com roscovitina (vermelha). (código PDB 2a41)..... 108

Figura 68 - Sobreposição do modelo da CDK11 $\Delta$ (cinza) com o ATP (amarelo) com o modelo da CDK11 $\Delta$ (azul) com roscovitina (vermelha). 108

Figura 69 - Principais interações de van der waals da CDK2 com roscovitina (código PDB 2a41) 109

Figura 70 - Principais interações de van der waals do modelo gerado da CDK11 $\Delta$ com roscovitina 
Figura 71 - 4-aminomethyl-N-arylpyrazoles, em que o R será omitido afim de preservar as informações.

Figura 72 - Gráfico $\mathrm{F}_{0} / \mathrm{F}$ versus log [Composto 3a] e ajuste linear para CDK11 $1 \Delta$ e o composto $3 \mathrm{a}$.

Figura 73 - Gráfico $\mathrm{F}_{0} / \mathrm{F}$ versus log [Composto 3b] e ajuste linear para CDK11 $\Delta$ e o composto $3 b$.

Figura 74 - Gráfico $\mathrm{F}_{0} / \mathrm{F}$ versus log [Composto 3f] e ajuste linear para CDK11 $\mathrm{e}$ o composto $3 \mathrm{f}$.

Figura 75 - Linhagens celulares mantidas em cultivo. (A) Balb/C3T3 (controle); (B) MDA-MB-231 e (C) MCF-7

Figura 76 - Viabilidade de células Balb/C3T3, MDA-MB-231 e MCF-7 após 72h de incubação na presença de diferentes concentrações dos compostos $3 \mathrm{a}$ e $3 \mathrm{f}(10 \mu \mathrm{M}, 50$ $\mu \mathrm{M}$ e $100 \mu \mathrm{M}$ ) avaliada pelo método colorimétrico MTT

Figura 77 - Primers desenhados para amplificação do cDNA da CDK11 $\Delta$ em pETSUMO.

Figura 78 - Sequência do cDNA da CDK11 11 em pETSUMO, com o códon de início (laranja), cauda de histidina (roxo), sequência referente a proteína SUMO (amarelo), sítio da EcorI (verde claro), sequência referente a CDK11 $\Delta$, (vermelho), o códon de terminação (verde escuro) e o sítio da XhoI (azul) destacados.

Figura 79 - Amplificação da CDK11 $\Delta$ em temperatura de $69,8^{\circ} \mathrm{C}$.

Figura 80 - Análise do sequenciamento após alinhamento no programa MultiAlin. Em vermelho destacam-se as regiões idênticas entre a CDK11 $1 \Delta$ e o resultado do sequenciamento, já em azul as regiões idênticas apenas entre duas sequências.

Figura 81 - Gel de eletroforese das expressões a 37,20 e $12{ }^{\circ} \mathrm{C}$ da CDK $11 \Delta$ com a SUMO. Em que M - marcador; $12 \mathrm{p}$ - pellet a $12{ }^{\circ} \mathrm{C} ; 12 \mathrm{~s}$ - sobrenadante a $12{ }^{\circ} \mathrm{C} ; 20 \mathrm{p}-$ pellet a $20^{\circ} \mathrm{C} ; 20 \mathrm{~s}$ - sobrenadante a $20^{\circ} \mathrm{C} ; 37 \mathrm{p}$ - pellet a $37{ }^{\circ} \mathrm{C} ; 37 \mathrm{~s}$ - sobrenadante a $37{ }^{\circ} \mathrm{C}$

Figura 82 - Gel de eletroforese da expressão a $7^{\circ} \mathrm{C}$ da CDK11 $\Delta$ com a SUMO. Em que $\mathrm{M}$ - marcador; $7 \mathrm{p}$ - pellet a $7{ }^{\circ} \mathrm{C} ; 7 \mathrm{~s}$ - sobrenadante a $7^{\circ} \mathrm{C}$.

Figura 83 - Gel de eletroforese das expressões a $12{ }^{\circ} \mathrm{C}$ em meio LB da CDK11 $\Delta$ com a SUMO. Em que M - marcador; $2 p$ - pellet após 2 dias; $2 \mathrm{~s}$ - sobrenadante após 2 dias; $3 \mathrm{p}$ - pellet após 3 dias; $3 \mathrm{~s}$ - sobrenadante após 3 dias; $4 \mathrm{p}$ - pellet após 4 dias; $4 \mathrm{~s}-$ sobrenadante após 4 dias.

Figura 84 - Gel de eletroforese das expressões a $12{ }^{\circ} \mathrm{C}$ em meio LB otimizado da CDK11 $\Delta$ com pETSUMO. Em que M - marcador; $2 \mathrm{p}$ - pellet após 2 dias; $2 \mathrm{~s}$ sobrenadante após 2 dias; $3 \mathrm{p}$ - pellet após 3 dias; $3 \mathrm{~s}$ - sobrenadante após 3 dias; 4p pellet após 4 dias; $4 \mathrm{~s}$ - sobrenadante após 4 dias.

Figura 85 - Gel de eletroforese com os resultados da lise, reenovelamento e purificação da CDK8. Em que M - marcador; 5p - pellet após indução e após lavagens; SDSs sobrenadante após reenovelamento; I - impurezas (primeiro pico após aplicação da amostra SDSs na coluna de Níquel) e CDK8 - proteína de interesse (segundo pico após aplicação da amostra SDSs na coluna e Níquel).

Figura 86 - Espectro de dicroísmo circular para a CDK8 a $4 \mu \mathrm{M}$ em tampão Tris-HCl $20 \mathrm{mM}, \mathrm{NaCl} 50 \mathrm{mM}$, glicerol a 5\% (v/v), $\beta$-mercaptoetanol $10 \mathrm{mM}, \mathrm{pH}$ 7,4. 
Figura 87 - Avaliação da estabilidade térmica de CDK8 por dicroísmo circular em 208 $\mathrm{nm}$. CDK8 a $4 \mu \mathrm{M}$ em tampão Tris- $\mathrm{HCl} 20 \mathrm{mM}, \mathrm{NaCl} 50 \mathrm{mM}$, glicerol a 5\% (v/v), 10 $\mathrm{mM} \beta$-mercaptoetanol, $\mathrm{pH} 7,4$

Figura 88 - Avaliação da estabilidade térmica de CDK8 por dicroísmo circular em diferentes temperaturas.

Figura 89 - Espectro de emissão de fluorescência para CDK8 frente a diferentes concentrações de ureia (de $0 \mathrm{M}$ a $8 \mathrm{M}$ ).

Figura 90 - Espectro de emissão de fluorescência para CDK8 frente a diferentes concentrações de ATP.

Figura 91 - Gráfico $F_{0} / F$ versus [ATP] para a CDK8 em função da concentração de ATP.

Figura 92 - Gráfico $\log \left(\mathrm{F}_{0}-\mathrm{F} / \mathrm{F}\right)$ versus $\log [\mathrm{ATP}]$ para a $\mathrm{CDK} 8$ e seu respectivo ajuste linear.

Figura 93 - Gráfico $\mathrm{F}_{0} / \mathrm{F}$ versus $\log$ [Composto 3a] e ajuste linear para CDK8 e o composto $3 \mathrm{a}$.

Figura 94 - Gráfico $\mathrm{F}_{0} / \mathrm{F}$ versus $\log$ [Composto $\left.3 b\right]$ e ajuste linear para CDK8 e o composto $3 b$.

Figura 95 - Gráfico $\mathrm{F}_{0} / \mathrm{F}$ versus log [Composto $\left.3 \mathrm{f}\right]$ e ajuste linear para CDK8 e o composto $3 \mathrm{f}$.

Figura 96 - PCR 1.

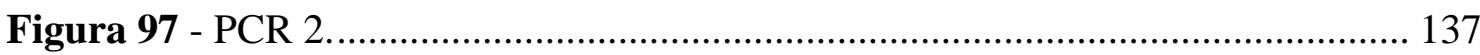

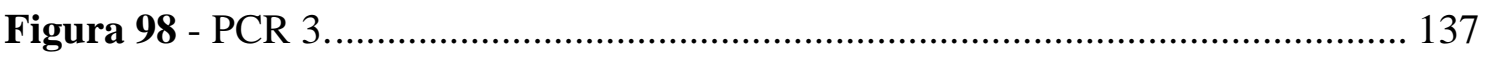

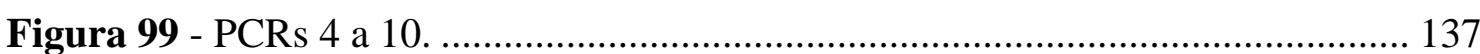

Figura 100 - Gel de eletroforese da expressão a $30^{\circ} \mathrm{C}$ da CDK11 $\Delta$. Em que M marcador; $2 \mathrm{~s}$ - sobrenadante após 2 horas, $2 \mathrm{p}$ - pellet após 2 horas, $6 \mathrm{~s}$ - sobrenadante após 6 horas, $6 \mathrm{p}$ - pellet após 6 horas 22s - sobrenadante após 22 horas, 22p - pellet após 22 horas.

Figura 101 - Gel de eletroforese da expressão a $18^{\circ} \mathrm{C}$ da CDK11 $\Delta$. Em que M marcador; $2 \mathrm{~s}$ - sobrenadante após 2 horas, $2 \mathrm{p}$ - pellet após 2 horas, $6 \mathrm{~s}$ - sobrenadante após 6 horas, $6 \mathrm{p}$ - pellet após 6 horas 22s - sobrenadante após 22 horas, 22p - pellet após 22 horas.

Figura 102 - Gel de eletroforese da expressão 1, a $37^{\circ} \mathrm{C}$ da CDK11 $\Delta$. Em que M marcador; $0 \mathrm{~s}$ - sobrenadante após 0 horas, $0 \mathrm{p}$ - pellet após 0 horas, $3 \mathrm{~s}$ - sobrenadante após 3 horas, $3 p$ - pellet após 3 horas, $7 \mathrm{~s}$ - sobrenadante após 7 horas, $7 \mathrm{p}$ - pellet após 7 horas.

Figura 103 - Gel de eletroforese da expressão 2, a $37^{\circ} \mathrm{C}$ da CDK11 $\Delta$. Em que M marcador; 0s - sobrenadante após 0 horas, $0 \mathrm{p}$ - pellet após 0 horas, $3 \mathrm{~s}$ - sobrenadante após 3 horas e sonicação, $3 p$ - pellet após 3 horas e sonicação.

Figura 104 - Gel de eletroforese da expressão 3, a $37^{\circ} \mathrm{C}$ da CDK11 $\Delta$. Em que M marcador; SDSs- sobrenadante após solubilização de SDS sem sonicação e SDSs*sobrenadante após solubilização de SDS com sonicação.

Figura 105 - Gel de eletroforese da expressão 4, a $37^{\circ} \mathrm{C}$ da CDK11 $\Delta$. Em que M marcador; 0s - sobrenadante após 0 horas, $0 \mathrm{p}$ - pellet após 0 horas, $3 \mathrm{~s}$ - sobrenadante 
após 3 horas e sonicação, 3p - pellet após 3 horas e sonicação,SDSs- sobrenadante após solubilização de SDS e centrifugação, SDSp- pellet após solubilização de SDS e centrifugação KCls- sobrenadante após utilização de $\mathrm{KCl}$ e centrifugação e $\mathrm{KClp}$ - pellet após utilização de $\mathrm{KCl}$ e centrifugação.

Figura 106 - Gel de eletroforese da expressão 5, a $37^{\circ} \mathrm{C}$ da CDK11 $\Delta$. Em que M marcador; $0 \mathrm{~s}$ - sobrenadante após 0 horas, $0 \mathrm{p}$ - pellet após 0 horas, $3 \mathrm{~s}$ - sobrenadante após 3 horas e sonicação, $3 \mathrm{p}$ - pellet após 3 horas e sonicação, 86s- sobrenadante após solubilização de SDS e centrifugação a $8600 \mathrm{rpm}$, 86p- pellet após solubilização de SDS e centrifugação a 8600rpm 110s- sobrenadante após solubilização de SDS e centrifugação a 11000rpm, 110p- pellet após solubilização de SDS e centrifugação a $11000 \mathrm{rpm}$.

Figura 107 - Gel de eletroforese da expressão 6, a $37^{\circ} \mathrm{C}$ da CDK11 $\Delta$. Em que M marcador; $0 \mathrm{~s}$ - sobrenadante após 0 horas, $0 \mathrm{p}$ - pellet após 0 horas, $5 \mathrm{~s}$ - sobrenadante após 5 horas e sonicação, $5 \mathrm{p}$ - pellet após 5 horas e sonicação, SDSs- sobrenadante após solubilização de SDS e centrifugação, SDSp - pellet após solubilização de SDS e centrifugação.

Figura 108 - Gel de eletroforese da expressão 7, a $37^{\circ} \mathrm{C}$ da CDK11 $\Delta$. Em que M marcador; 0s - sobrenadante após 0 horas, $0 \mathrm{p}$ - pellet após 0 horas, $5 \mathrm{~s}$ - sobrenadante após 5 horas e sonicação, $5 \mathrm{p}$ - pellet após 5 horas e sonicação, SDSs- sobrenadante após solubilização de SDS e centrifugação, SDSp - pellet após solubilização de SDS e centrifugação, $\mathrm{L}$ - lavagem do pellet.

Figura 109 - Gel de eletroforese da expressão 7, a $37^{\circ} \mathrm{C}$ da CDK11 11 . Em que M marcador e os demais são as amostras após purificação por coluna de afinidade ao níquel, sendo 5 a 8 - os picos do cromatograma das impurezas e de 60 a 64 - os picos do cromatograma relativos a proteína de interesse.

Figura 110 - Gel de eletroforese da expressão 8, a $37^{\circ} \mathrm{C}$ da CDK11 1 . Em que M marcador; $5 \mathrm{~s}$ - sobrenadante após 5 horas e sonicação, $5 \mathrm{p}$ - pellet após 5 horas e sonicação, SDSs- sobrenadante após solubilização de SDS e centrifugação, SDSp pellet após solubilização de SDS e centrifugação, $\mathrm{L}$ - lavagem do pellet, 8 - um dos picos do cromatograma das impurezas, 64 - um dos picos do cromatograma relativo a proteína de interesse, AS - amostra antes da superdex, DS - amostra depois da superdex.

Figura 111 - Gel de eletroforese da expressão 9, a $37^{\circ} \mathrm{C}$ da CDK11 $\Delta$. Em que M marcador; L1 a L3 são as lavagens do pellet, 5p - pellet após 5 horas e sonicação, SDSs- sobrenadante após solubilização de SDS e centrifugação, I - impurezas depois da coluna de níquel, $\mathrm{P}$ - proteína CDK11 $\Delta$ depois da coluna de níquel.

Figura 112 - Gel de eletroforese da expressão 10, a $37^{\circ} \mathrm{C}$ da $\mathrm{CDK} 11 \Delta$. Em que M marcador; $5 \mathrm{~s}$ - sobrenadante após 5 horas e sonicação, L1 a L3 são as lavagens do pellet, $5 \mathrm{p}$ - pellet após 5 horas e sonicação, SDSs- sobrenadante após solubilização de SDS e centrifugação, I - impurezas depois da coluna de níquel, P - proteína CDK11 $\Delta$ depois da coluna de níquel.

Figura 113 - Gel de eletroforese da expressão 11 , a $37^{\circ} \mathrm{C}$ da $\mathrm{CDK} 11 \Delta$. Em que M marcador; $5 \mathrm{~s}$ - sobrenadante após 5 horas e sonicação, L1 a L3 são as lavagens do pellet, 5 p - pellet após 5 horas e sonicação, SDSs- sobrenadante após solubilização de SDS e centrifugação, I - impurezas depois da coluna de níquel, P - proteína CDK11 $\Delta$ depois da coluna de níquel. 


\section{LISTA DE TABELAS}

Tabela 1 - Inibidores da CDK em desenvolvimento clínico.

Tabela 2 - CDK11 e o câncer de mama, ovário, osteossarcoma e lipossarcoma.

Tabela 3 - Variação das condições do PCR para amplificação do cDNA da CDK11 4.47

Tabela 4 - Volumes e concentração dos reagentes utilizados na reação de digestão do vetor e do inserto.

Tabela 5 - Reação de ligação entre o vetor e o inserto. ................................................. 48

Tabela 6 - Reação de PCR de colônia utilizando os primers da CDK11 $\Delta$.

Tabela 7 - Testes de expressão utilizando diferentes condições. Em vermelho são mostradas as melhores condições para a superexpressão, lise e reenovelamento da CDK11 $1 \Delta$.

Tabela 8 - Comparação do percentual de estrutura secundária da CDK11 $\Delta$, obtido por diferentes metodologias.

Tabela 9 - Percentual de estrutura secundária da CDK11 $\Delta$ modelada a partir de diferentes moldes.

Tabela 10 - Principais características dos moldes utilizados na modelagem denominada "MODELLER com diferentes CDKs".

Tabela 11 - Principais características dos moldes utilizados na modelagem denominada "MODELLER com várias CDKs 2 e uma CDK7".

Tabela 12 - Interações do ATP com a cadeia principal dos resíduos de aminoácidos das CDKs 2 e 11.

Tabela 13 - Região de interação com ATP e resíduos de aminoácidos envolvidos nas CDKs 2 e 11

Tabela 14 - Região de interação com ATP e resíduos de aminoácidos envolvidos nas CDKs 2,11 e 10 . 


\section{LISTA DE ABREVIATURAS E SIGLAS}

AR receptor androgênico, do inglês androgen receptor

ATP adenosine trifosfato

CAK quinase ativadora de $\mathrm{CDK}$, do inglês CDK-activating kinase

CAQI Central de Análises Químicas Instrumentais

CD dicroísmo circular, do inglês circular dichroism

CDK quinase dependente de ciclina, do inglês cyclin dependente kinase

cDNA complementary DNA

CKI proteínas inibidoras de quinases dependente de ciclina, do inglês cyclindependent kinase inhibitor

CRISPR clustered regularly interspaced short palindromic repeats

CTD domínio C-terminal, do inglês $C$-terminal domain

DA doença de Alzheimer

ddNTPs dideoxynucleotide triphosphates

DMSO dimetilsulfóxido

DNA ácido desoxirribonucleico

DO densidade ótica

DOPE $\quad$ Discrete Optimized Protein Energy

E2F E2 factor

eIF3 fator de iniciação eucariótico, do inglês eukaryotic initiation factor 3

FDA Food and Drug Administration

GMQE Global Model Quality Estimation

HER2- receptor de fator de crescimento epidérmico tipo 2 negativo

HIV vírus da imunodeficiência humana

IFSC Instituto de Física de São Carlos

IMAC cromatografia de afinidade por íon metálico imobilizado, do inglês immobilized metal ion affinity chromatography

IPTG isopropil B-D-1-tiogalactopiranosídeo

IQSC Instituto de Química de São Carlos 
IRES local interno de entrada no ribossomo, do inglês internal ribosome entry site

LB Luria-Bertani

Med27 mediator complex subunit 27

Med4 mediator complex subunit 4

MPD 2-metil-2,4-pentanodiol

mRNA RNA mensageiro

NLS Sinal de localização nuclear, do inglês nuclear location signal

PAK1 quinase 1 ativada por $\mathrm{p} 21$, do inglês $p 21$-activated kinase 1

PCR reação em cadeia da polimerase, do inglês polimerase chain reaction

PDB banco de dados de proteína, do inglês Protein Data Bank

PEG4000 polietilenoglicol 4000

PMSF fluoreto de fenilmetilsulfonil, do inglês phenylmethylsulfonyl fluoride

$\mathrm{Rb} \quad$ retinoblastoma

RE domínio domínio de ligação arginina/ácido glutâmico

$\mathrm{RH}+\quad$ receptor hormonal positivo

RNA ácido ribonucleico

RNAi RNA de interferência

RNAPII RNA polymerase II

SAR relação estrutura-atividade, do inglês structure-activity relationships

SDS dodecil sulfato de sódio, do inglês sodium dodecyl sulfate

SDS-PAGE Eletroforese em gel de poliacrilamida e dodecil sulfato de sódio, do inglês sodium dodecyl sulfate - polyacrylamide gel electrophoresis

shRNA small hairpin RNA

siRNA small interfering RNA

SUMO Small Ubiquitin-like Modifier

TFIIF fator de transcrição IIF, do inglês transcription fator IIF

TFIIS fator de transcrição IIS, do inglês transcription fator IIS

TNBC câncer de mama triplo negativo, do inglês triple negative breast cancer

UEM Universidade Estadual de Maringá

VLPs partículas semelhantes a vírus, do inglês virus like particles 


\section{LISTA DE EQUAÇÕES}

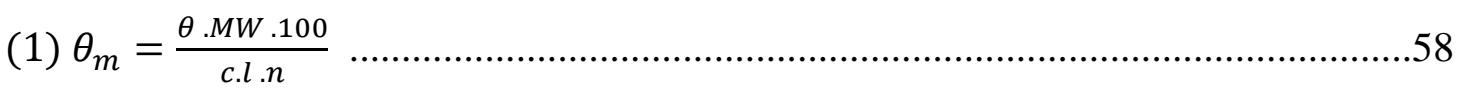

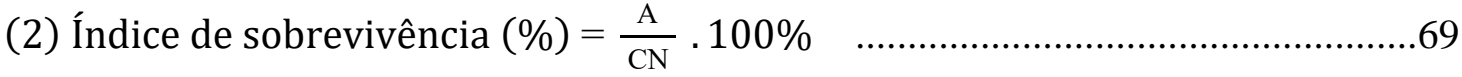

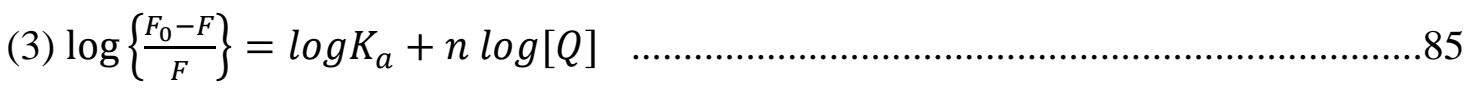




\section{SUMÁRIO}

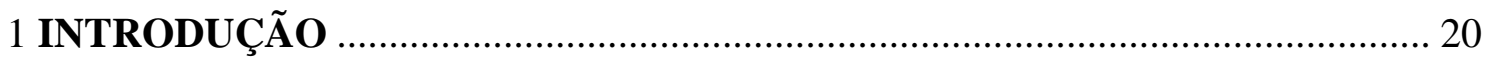

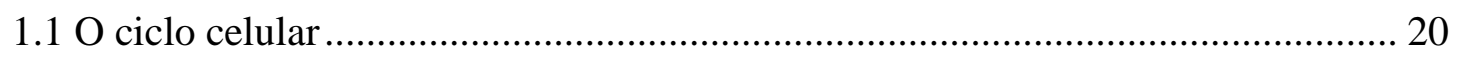

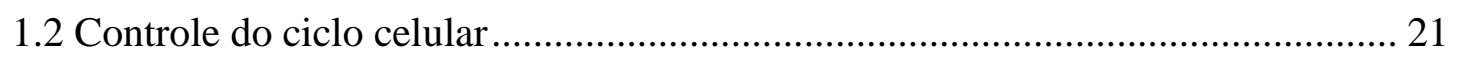

1.3 Proteínas quinases dependentes de ciclinas (CDKs) …………………………...... 22

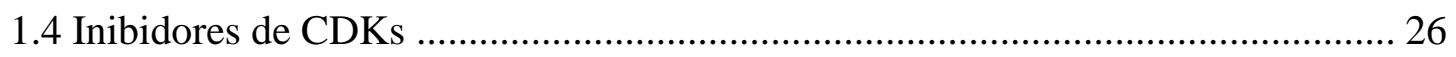

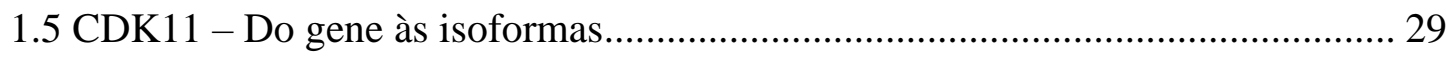

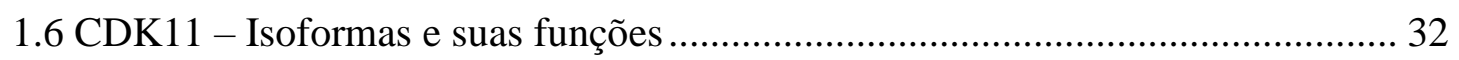

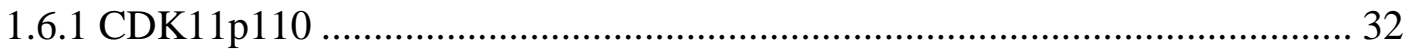

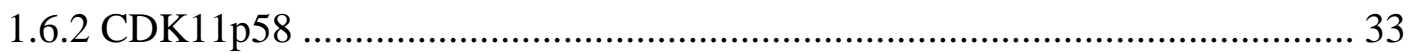

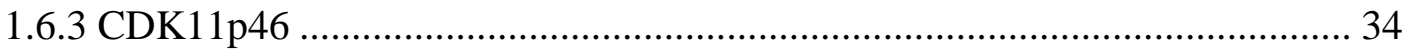

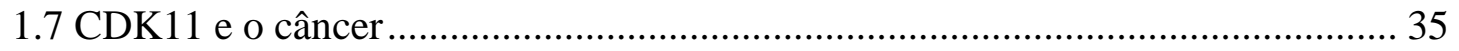

1.7.1 CDK11 em câncer de mama....................................................................... 36

1.7.2 CDK11 em câncer de ovário ....................................................................... 37

1.7.3 CDK11 em osteossarcoma ……………………………............................ 37

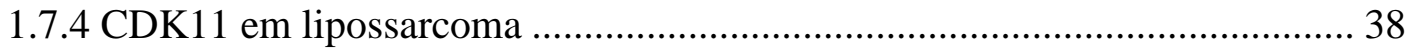

1.7.5 CDK11 em outros tipos de câncer............................................................... 38

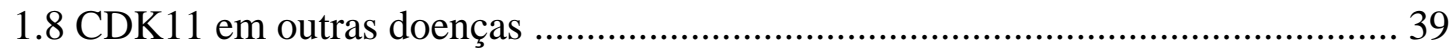

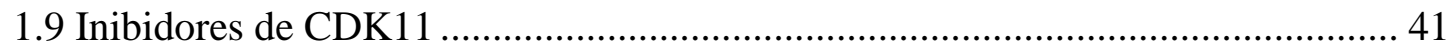

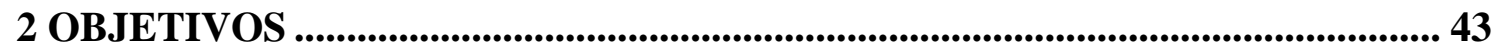

2.1 Objetivo Principal ............................................................................................. 43

2.2 Objetivos Específicos ................................................................................... 43

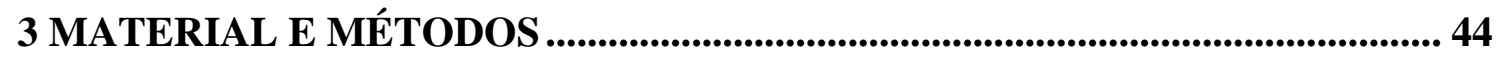

3.1 Clonagem da CDK11 $\Delta$ em pET28a............................................................... 44

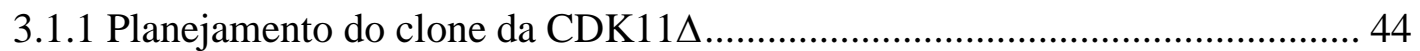

3.1.2 Amplificação do cDNA da CDK11 …………………………………..... 47

3.1.3 Digestão e Ligação ...................................................................................... 47

3.1.4 Transformação do produto de ligação em células DH5 a................................ 48

3.1.5 PCR de colônia.......................................................................................... 49

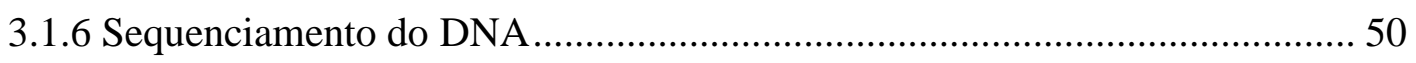

3.2 Expressão, reenovelamento e purificação da $\operatorname{CDK} 11 \Delta$ a partir do recombinante pET28a:CDK11

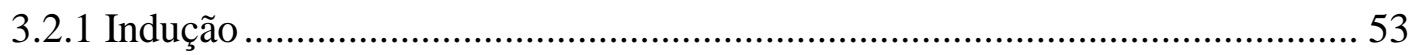

3.2.2 Lise das células.......................................................................................... 53 


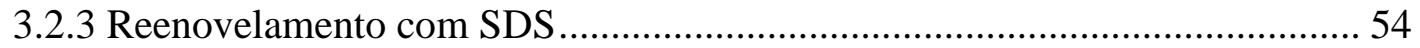

3.2.4 Purificação por cromatografia de afinidade ................................................ 54

3.2.5 Eletroforese em gel de poliacrilamida (SDS-PAGE) .................................. 56

3.2.6 Diálise e determinação da concentração e pureza da proteína obtida ............. 56

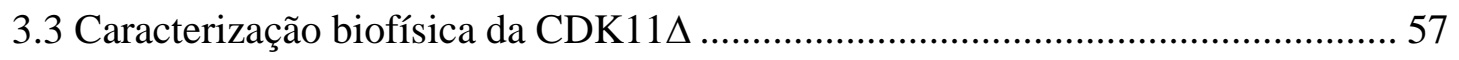

3.3.1 Espectroscopia de dicroísmo circular...................................................... 57

3.3.1.1 Metodologia dos experimentos de espectroscopia de dicroísmo circular 58

3.3.1.2 Determinação do percentual de estrutura secundária da CDK11 $\Delta$.......... 58

3.3.1.3 Estabilidade da estrutura secundária após armazenamento da CDK11 a

$4{ }^{\circ} \mathrm{C}$

3.3.1.4 Determinação da influência da concentração na estrutura secundária da CDK11 $1 \Delta$

3.3.1.5 Determinação da influência da temperatura na estabilidade da estrutura secundária da CDK11

3.3.2 Espectroscopia de emissão de Fluorescência ................................................ 59

3.3.2.1 Estudo da estabilidade química na presença de ureia............................. 61

3.3.2.2 Estudo da interação da CDK11 1 com ATP........................................... 61

3.3.2.3 Estudo da interação da CDK11 $\Delta$ com roscovitina ................................... 62

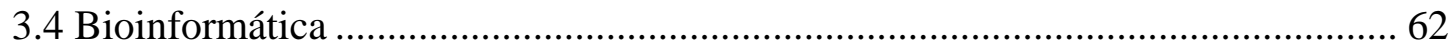

3.4.1 Modelagem molecular da CDK11

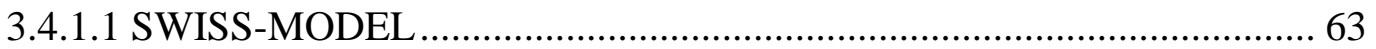

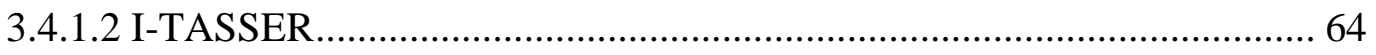

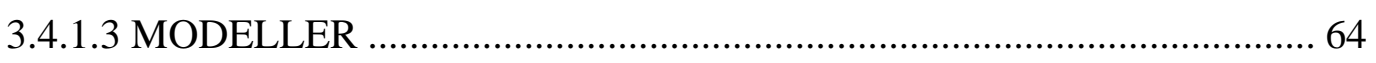

3.4.2 Inserção dos ligantes por modelagem molecular e análise das interações ..... 65

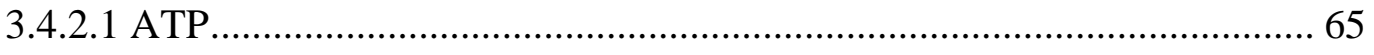

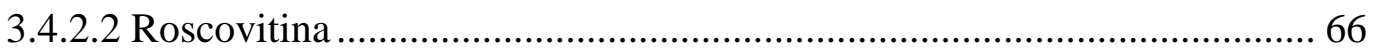

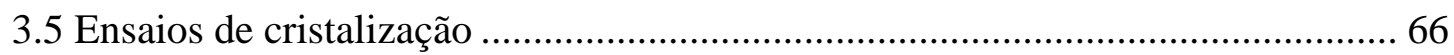

3.6 Estudos dos potenciais inibidores 3a, 3b e 3f com a CDK11 …........................ 68

4 RESULTADOS E DISCUSSÃO ........................................................................... 70

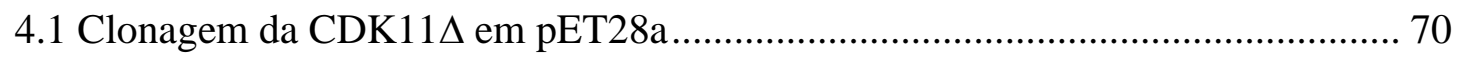

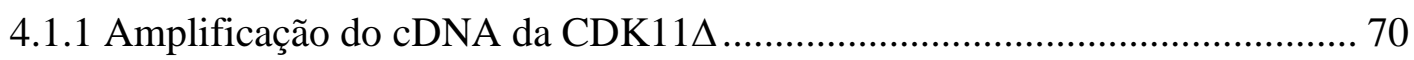

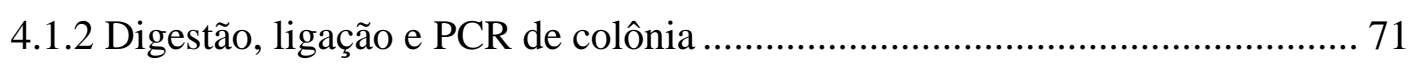

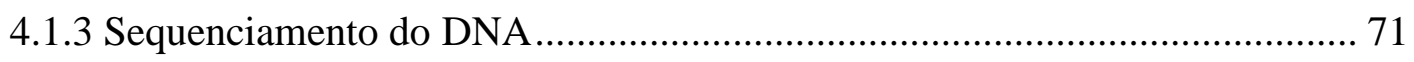


4.2 Expressão, reenovelamento e purificação da CDK11 $\Delta$ a partir do recombinante

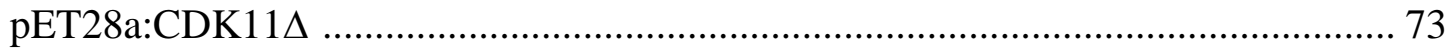

4.3 Caracterização biofísica da CDK11 …….......................................................... 76

4.4 Espectroscopia de dicroísmo circular........................................................... 76

4.4.1 Determinação do percentual de estrutura secundária da CDK11

4.4.2 Estabilidade da estrutura secundária após armazenamento da CDK11 $\Delta$ a

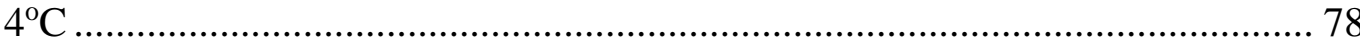

4.4.3 Determinação da influência da concentração de CDK11 1 na sua estrutura

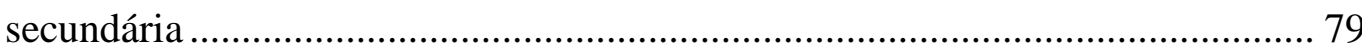

4.4.4 Determinação da influência da temperatura na estabilidade da estrutura secundária da CDK11

4.5 Espectroscopia de emissão de Fluorescência .................................................. 81

4.5.1 Estudo da estabilidade química na presença de ureia.............................. 81

4.5.2 Estudo da interação da CDK11 1 com ATP ............................................ 82

4.5.3 Estudo da interação da CDK11 $\Delta$ com roscovitine …................................. 86

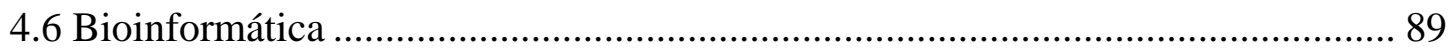

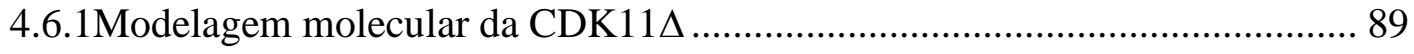

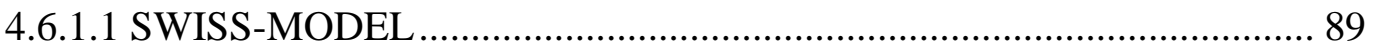

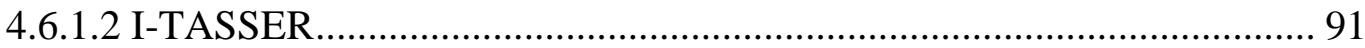

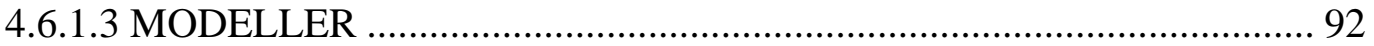

4.6.2 Inserção dos ligantes por modelagem molecular e análise das interações ..... 95

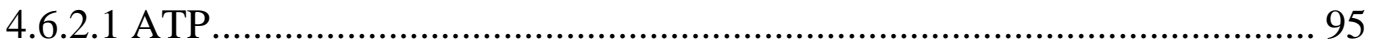

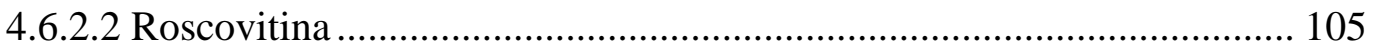

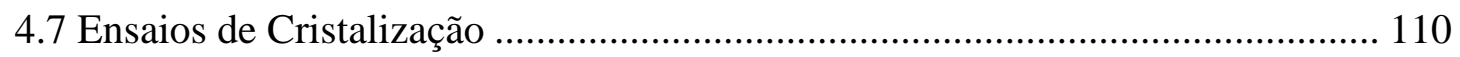

4.8 Estudos dos potenciais inibidores 3a, 3b e 3f com a CDK11 …...................... 110

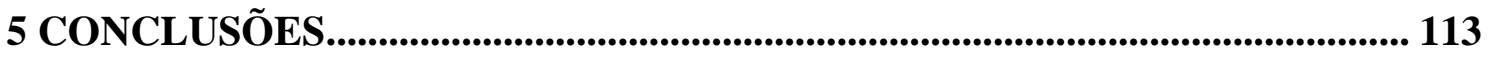

6 PARTICIPAÇÃO EM OUTROS PROJETOS..................................................... 114

6.1 Clonagem da CDK11 $\Delta$ em pETSUMO e testes de expressão............................ 114

6.2 Purificação e caracterização biofísica da CDK8 ……...................................... 118

6.3 Estudos dos potenciais inibidores 3a, 3b e 3f com a CDK8 …........................ 124

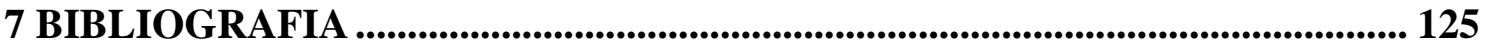




\section{INTRODUÇÃO}

\subsection{0 ciclo celular}

O ciclo celular é fundamental para garantir crescimento, regeneração, reprodução e renovação celular e é dividido nas fases $S, M, G_{1}$ e $G_{2}$ (Figura 1).

Figura 1 - As quatro fases do ciclo celular.

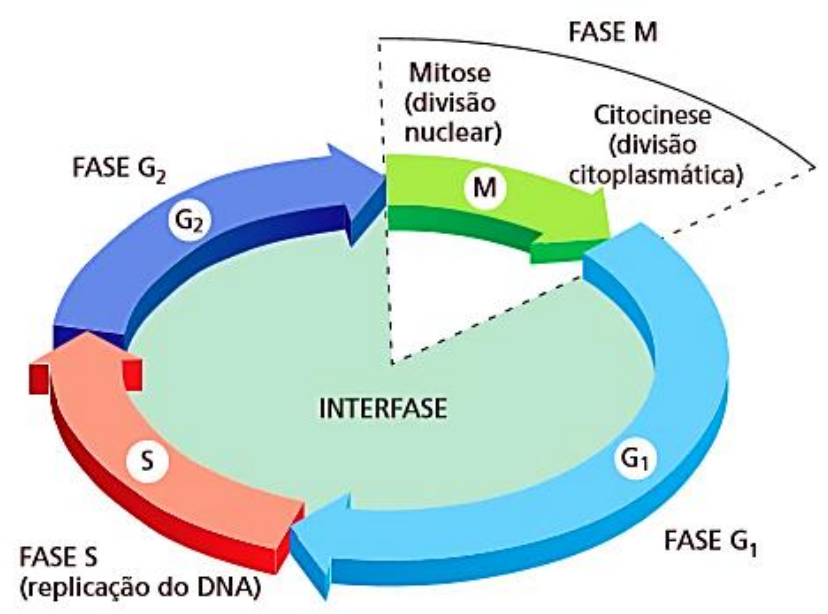

Fonte: ALBERTS et al., 2017.

$\mathrm{Na}$ fase $\mathrm{S}$, fase de síntese, ocorre a duplicação do DNA cromossômico, na fase $\mathrm{G}_{2}$ a célula praticamente dobra de tamanho, pois novas proteínas são sintetizadas. Na fase M, ocorre a divisão do núcleo (mitose), após o envelope nuclear ser degradado, os cromossomos pareados são puxados para os polos da célula e um novo envelope nuclear envolve cada conjunto de cromossomos filhos, por fim ocorre a divisão citoplasmática (citocinese) que completa a divisão da célula mãe em duas células-filhas (NELSON e COX, 2014 e DEVLIN, 2011).

O período entre uma fase $\mathrm{M}$ e a próxima é denominado de interfase, nela ocorrem as fases $\mathrm{G}_{1}, \mathrm{~S}$ e $\mathrm{G}_{2}$. As fases $\mathrm{G}$ se referem a um intervalo entre as fases ( $\mathrm{g} a p$, em inglês) no qual a célula se prepara para a próxima fase. A fase $G_{1}$ é o intervalo entre a fase $M$ e a $\mathrm{S}$ e $\mathrm{G}_{2}$ é o intervalo entre a fase $\mathrm{S}$ e a $\mathrm{M}$ (ALBERTS et al., 2017).

Após a divisão celular, ou a célula entra na fase $G_{1}$, em que ocorre a síntese de proteínas e ácido ribonucleico (RNA), ou então pode entrar em uma fase denominada $\mathrm{G}_{0}$, 
que não faz parte diretamente do ciclo celular, mas ocorre em equilíbrio com a fase $\mathrm{G}_{1}$. Nela a célula pode estar num estado chamado de quiescente em que a célula pode reentrar no ciclo celular se induzida por um estímulo mitótico (como um aumento na concentração de um fator de crescimento em seu ambiente externo) ou num estado senescente, em que a célula não pode ser induzida a reentrar no ciclo celular mesmo na presença de fatores de crescimento. Se a célula em $G_{0}$ retornar ao ciclo celular, ela reinicia pela fase $G_{1}$ (DEVLIN, 2011).

A divisão celular ocorre em praticamente todos os tecidos durante o crescimento e desenvolvimento embrionário, mas no organismo adulto a maioria das células estão na fase quiescente (NELSON e COX, 2014)

\subsection{Controle do ciclo celular}

Principalmente nas fases $\mathrm{G}_{1}$ e $\mathrm{G}_{2}$ há vários pontos de checagens (Figura 2) em que a célula decide se vai para a próxima fase ou se vai parar para que a célula tenha mais tempo para se preparar (ALBERTS et al., 2017).

Figura 2 - $\mathrm{O}$ controle do ciclo celular

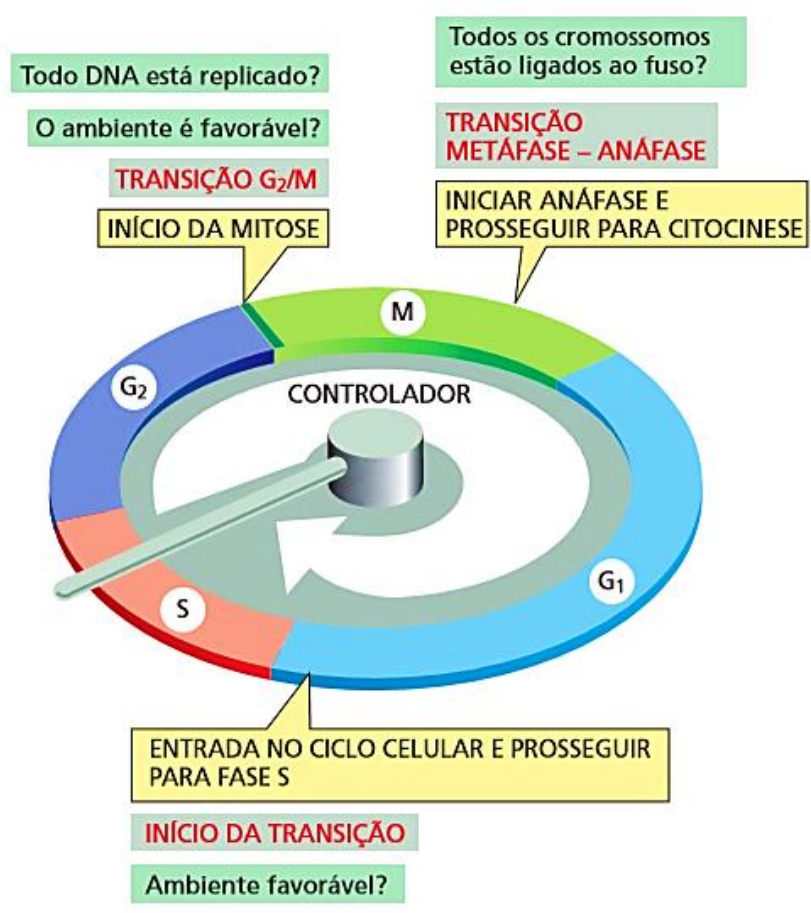

Fonte: ALBERTS et al., 2017 
O ponto de checagem que ocorre em $\mathrm{G}_{1}$, conhecido como checkpoint de início de ciclo celular ou de restrição, permite que a célula confirme se o DNA está intacto e se o meio é favorável para a proliferação celular. Assim a célula em condições favoráveis passa para a fase $\mathrm{S}$ (de replicação do DNA), mas em condições desfavoráveis ela atrasa $\mathrm{G}_{1}$ ou entra em repouso na fase denominada $\mathrm{G}_{0}$, que pode durar dias, horas ou até toda a vida da célula. $\mathrm{G}_{1}$ é fortemente regulado por CDK6/ciclina $\mathrm{D}, \mathrm{CDK} 4 /$ ciclina $\mathrm{D}$ e CDK2/ciclina E (SKOTHEIM et al., 2008 e ALBERTS et al., 2017).

$\mathrm{O}$ ponto em $\mathrm{G}_{2}$, conhecido como checkpoint $\mathrm{G}_{2} / \mathrm{M}$ ou ponto de verificação de danos do DNA, assegura que a célula não entre em mitose até que o DNA esteja completamente reparado e a replicação do DNA esteja completa, este ponto de verificação é fortemente regulado por CDK2/Ciclina B (GUARDAVACCARO e PAAGANO, 2006 e ALBERTS et al., 2017).

De leveduras a humanos o controle correto do ciclo celular depende de proteínas que precisam ser ativadas e inativadas no momento correto. Uma das maneiras mais comuns de fazer esse controle é a ativação ou desativação de proteínas específicas através do processo de fosforilação e desfosforilação que são feitos respectivamente por proteínas quinases e proteínas fosfatases (Figura 3) (ALBERTS et al., 2017).

Figura 3 - Representação dos processos de fosforilação e desfosforilação.
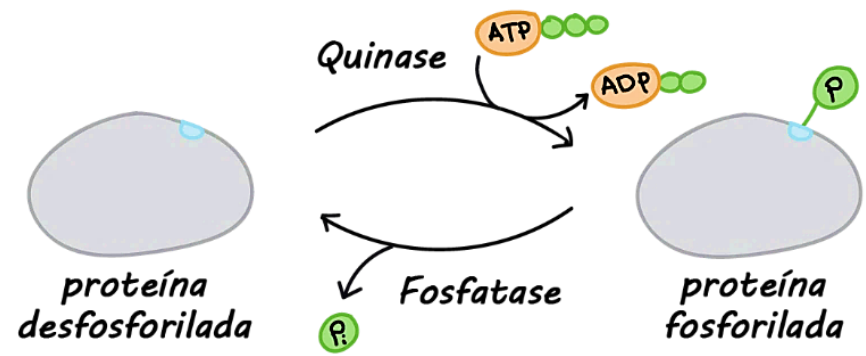

Fonte: https://pt.khanacademy.org/science/biology/cell-signaling/mechanisms-of-cellsignaling/a/intracellular-signal-transduction

\subsection{Proteínas quinases dependentes de ciclinas (CDKs)}

O estudo de proteínas quinases trouxe descobertas importantes para diversas áreas da ciência e propiciou a obtenção de um prêmio Nobel em 1992 para os químicos Edmond H. Fischer e Edwin G. Krebs em Fisiologia e Medicina por seus estudos com a proteína quinase A (PKA) (NOBEL PRIZE,1992). 
A motivação do prêmio foi por suas descobertas sobre o processo de fosforilação, feito por proteínas quinases, ser essencial na regulação de diversos processos biológicos (NOBEL PRIZE,1992). Desde então muitos pesquisadores têm focado suas pesquisas em descobrir e entender o papel das quinases.

O genoma humano possui em torno de 500 genes que codificam proteínas quinases, o que corresponde a cerca de $2 \%$ de todos os genes humanos (MANNING et al., 2002).

Dentro da família das quinases existe uma subfamília de proteínas denominada quinases dependentes de ciclinas (CDKs) que necessitam de uma proteína parceira, chamada ciclina, para ser ativada (ALBERTS et al., 2017). Até o momento, foram descobertas cerca de 20 CDKs (Figura 4), (WHITTAKER et al., 2017).

Figura 4 - Relação evolutiva entre as CDKs e as ciclinas necessárias para sua ativação. Domínio quinase (verde), domínios ricos em arginina/serina (rosa); ácido glutâmico (azul), glutamina (amarelo) e prolina (vermelho). Para a CDK11 são mostradas as isoformas p58 e p110.

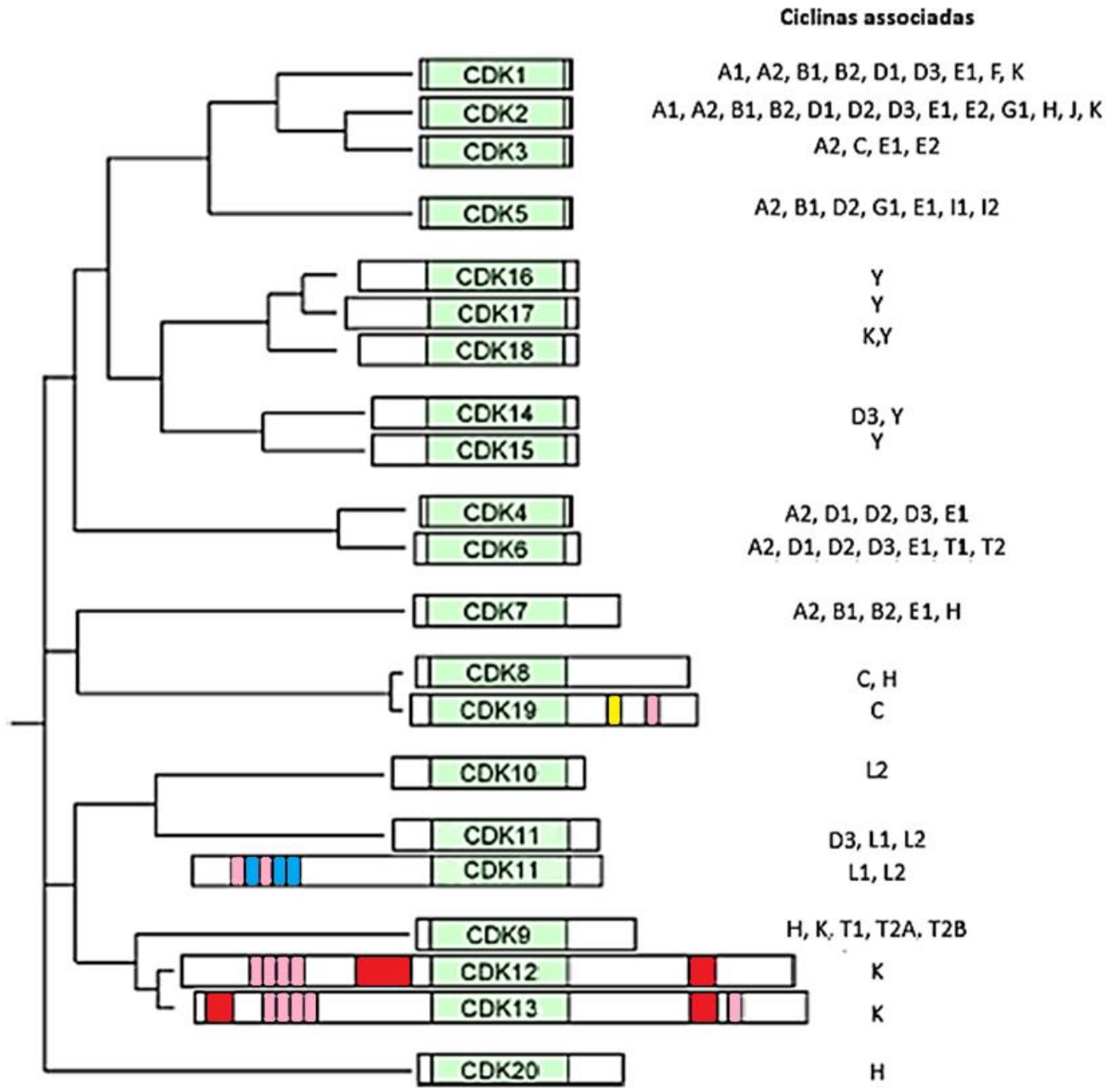

Fonte: WHITTAKER et al., 2017. 
As CDKs são classificadas em subfamílias relacionadas ao ciclo celular (CDKs 1-6, 11, 14-18) e/ou a transcrição (CDKs 7-13, 19 e 20) (WHITTAKER et al., 2017). Todas as CDKs ativam ou desativam outras proteínas específicas através da fosforilação de resíduos de serina/treonina e por isso elas são classificadas como serina-treonina quinases (ALBERTS et al., 2017).

As CDKs são ativadas e inativadas em momentos específicos conforme a célula necessite, em resposta a sinais extra e intracelulares. A ativação total das CDKs necessita de três etapas (Figura 5):

- Etapa 1 - CDK inativa - CDK sem sua parceira ciclina com seu sítio ativo bloqueado pela alça $\mathrm{T}$.

- Etapa 2-CDK parcialmente ativa - CDK se liga a sua parceira ciclina formando o complexo CDK/Ciclina, com a formação do complexo a alça $\mathrm{T}$ se afasta e a CDK pode ser fosforilada.

- Etapa 3 - CDK totalmente ativa - CDK é fosforilada pela CAK (quinase ativadora de $\mathrm{CDK}$ ) e a fosforilação leva a uma alteração conformacional que ativa completamente a CDK.

Figura 5 - Ativação das CDKs. (A) CDK sem ciclina - seu sítio ativo fica bloqueado (B) CDK ligada a ciclina - a alça T se afasta e a CDK pode ser fosforilada (C) CDK após fosforilação pela

CAK - alteração conformacional que a ativa completamente.

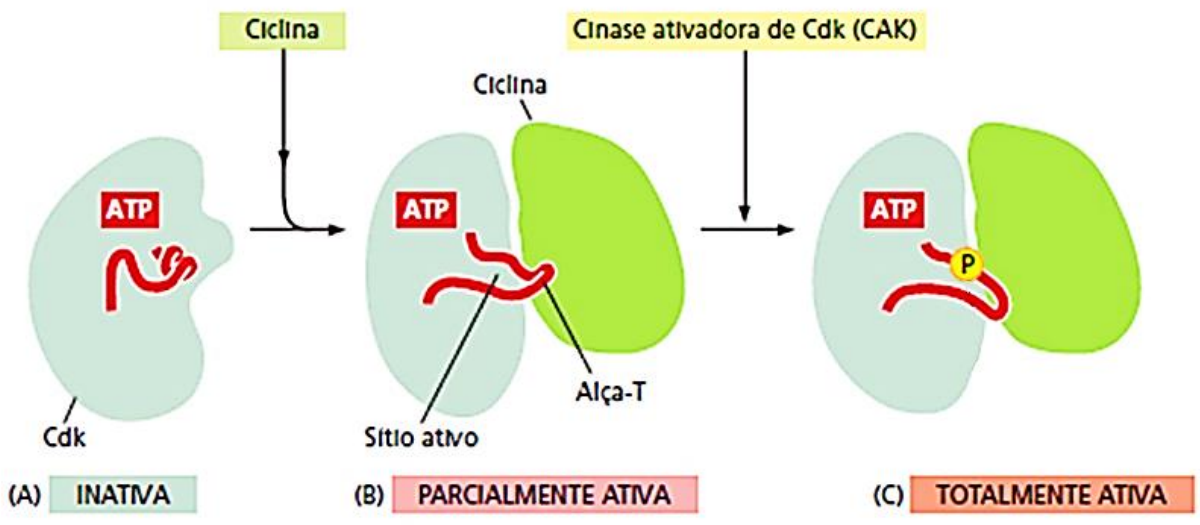

Fonte: ALBERTS et al., 2017. 
Ativadas, as CDKs catalisam a fosforilação de outras proteínas que executam funções críticas no ciclo celular. As CDKs, além de reguladas pela associação com ciclinas, são reguladas por outras proteínas quinases, por proteínas fosfatase, ou ainda pela ausência ou presença de proteínas inibidoras de CDKs (CKIs) (DEVLIN, 2011).

A concentração de CDKs não se altera de modo significativo durante o ciclo celular, mas a partir do controle das concentrações das ciclinas temporal e espacialmente, durante os eventos do ciclo celular, as CDKs são controladas (NELSON e COX, 2014).

Toda essa sincronia do ciclo celular ocorre de maneira orquestrada, em cada caso uma proteína ciclina específica é produzida para se ligar a CDK, fosfatos ativadores são adicionados pelas CAK e fosfatos inibidores são retirados por fosfatases, para gerar a atividade necessária para regular aquela etapa do ciclo celular. Ao fim de cada etapa a proteína ciclina do complexo é poliubiquitinada e degradada, desligando a atividade da CDK e permitindo a próxima etapa (NELSON e COX, 2014).

O monômero das CDKs consiste basicamente de três domínios: domínio Nterminal (rico em fitas $\beta$ ), domínio C-terminal (rico em $\alpha$-hélices) e domínio catalítico, responsável pela ligação do ATP (adenosine trifosfato), localizado entre os domínios N e $\mathrm{C}$ terminais.

Além desses domínios as CDKs apresentam conservadas duas estruturas de controle: T-loop ou alça T e Hélice C ou hélice N-terminal.

A CDK2 é a CDK mais bem estudada e caracterizada, um exemplo de mecanismo regulatório dessa CDK é descrito a seguir:

A CDK2 fosforilada em sua Tyr15, contida em seu sítio ativo, fica inativa, pois essa fosforilação impede a ligação do ATP. Ao desfosforilar a Tyr15 por uma fosfatase, o bolsão de ligação do ATP fica livre, mas a CDK ainda está inativa (Figura 6A) (NELSON e COX, 2014).

Em seguida ao se ligar a ciclina, a hélice $C$, que contêm a sequência PSTAIRE na CDK2, move-se em direção ao domínio catalítico trazendo o resíduo de Glu51 para dentro do bolsão de ligação de ATP, ao mesmo tempo a alça T se curva em direção ao C-terminal (Figura 6B). A fosforilação da Thr160 na alça T pela CAK desloca a alça para fora do sítio catalítico e expõe o ATP, aumentando a atividade da CDK2 (Figura 6C) (NELSON e COX, 2014). 
Figura 6 - Ativação da CDK2. (A) CDK2 sem ciclina (código PDB: 1HCK) - sítio ativo bloqueado pela alça $\mathrm{T}$, que obstrui o sítio de ligação para os substratos proteicos (B) CDK2 ligada a ciclina (código PDB: 1FIN) - a alça T se afasta e a hélice $C$ é reorientada trazendo o resíduo Glu51 para o sítio ativo. (C) CDK2 após fosforilação da Thr160 na laça T (código PDB: 1JST) produz resíduo negativamente carregado estabilizado ao interagir com três resíduos de Arg.
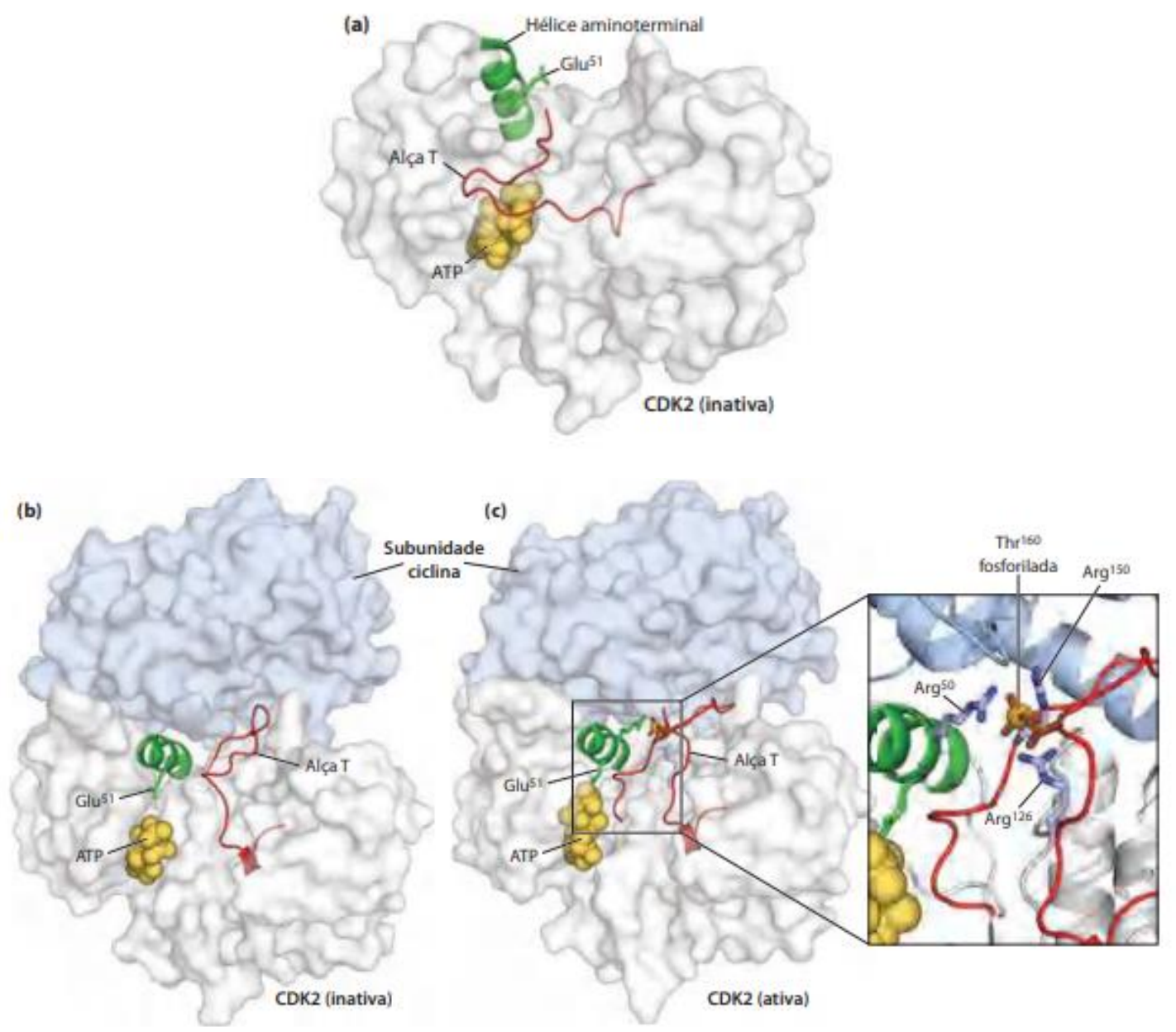

Fonte: NELSON e COX, 2014.

\subsection{Inibidores de CDKs}

Devido ao seu papel no controle do ciclo celular e/ou na transcrição, o crescimento celular normal está associado ao controle correto pelas CDKs, enquanto a superexpressão ou hiperativação de CDKs têm sido observadas em diversos tipos de câncer (PEYRESSATRE et al., 2015). 
Desde então essas proteínas têm se tornado um alvo em potencial no tratamento dessa doença. Apesar da desregulação de CDKs ser frequente em cânceres, cada CDK atua em etapas específicas e pode estar associada a diferentes tipos de câncer, o que corrobora para que mais estudos foquem na especificidade de atuação de cada proteína para que possam ser desenvolvidos inibidores seletivos (CHOHAN et al., 2018).

Após anos de estudos sobre CDKs, em 2015 a FDA (Food and Drug Administration) aprovou o primeiro inibidor de CDK, o Palbociclib, utilizado para o tratamento de câncer de mama avançado recepetor hormonal positivo $(\mathrm{RH}+)$ e receptor de fator de crescimento epidérmico tipo 2 negativo (HER2-) (FINN et al., 2016).

O Palbociclib foi identificado durante estudos de relação estrutura-atividade (SAR). Assim como o Palbociclib, outros inibidores foram aprovados em anos posteriores, o Ribociclib e o Abemaciclib. As três moléculas (Figura 7) são inibidores do tipo ATP competitivos, ou seja, se ligam no bolsão de ligação do ATP das CDKs 4 e 6, impedindo a transferência do fosfato para a proteína alvo (CHOHAN et al., 2018 e LIU, LIU e CHEN, 2018).

Figura 7- Estrutura do (A) Palbociclib (B) Ribociclib e (C) Ademaciclib.

(A)<smiles>CC(=O)c1c(C)c2cnc(Nc3ccc(N4CCNCC4)cn3)nc2n(C2CCCC2)c1=O</smiles>

(B)<smiles>CN(C)C(=O)c1cc2cnc(Nc3ccc(N4CCNCC4)cn3)nc2n1C1CCCC1</smiles>

(C)<smiles>CCN1CCN(Cc2ccc(Nc3ncc(F)c(-c4cc(F)c5nc(C)n(C(C)C)c5c4)n3)nc2)CC1</smiles>

Fonte: Autoria própria. 
As CDKs 4 e 6 agem fosforilando a proteína Retinoblastoma (Rb) (Figura 8). Ao impedir a ação dessas CDKs, os inibidores impedem a fosforilação da proteína $\mathrm{Rb}$, o que previne a liberação do E2F (E2 factor) necessário para transcrever genes que codificam proteínas que ativam a fase $S$, levando a parada do ciclo celular na fase $G_{1}$ e consequente supressão do crescimento tumoral (CHOHAN et al., 2018 e LIU, LIU e CHEN, 2018).

Figura 8 - Fosforilação da Rb por CDKs.

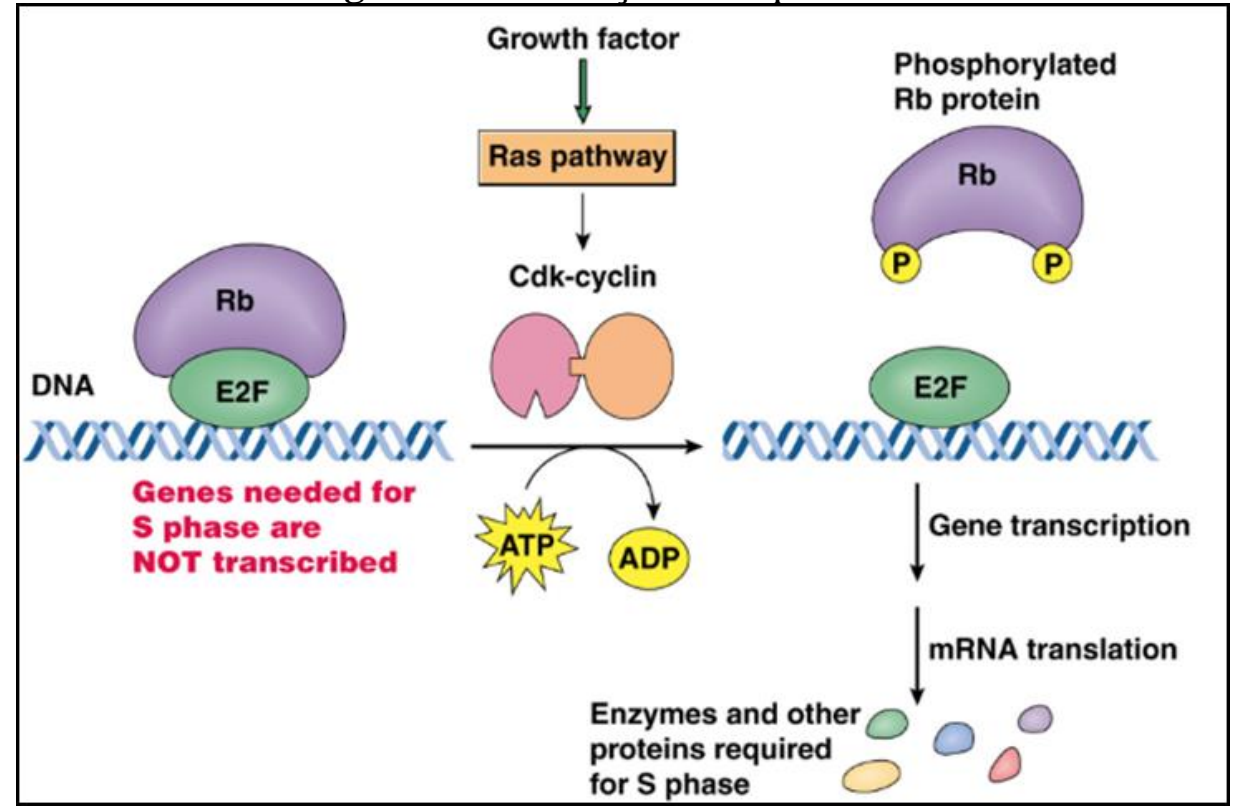

Fonte: https://www.mun.ca/biology/desmid/brian/BIOL2060/BIOL2060-19/19_39.jpg

Além desses inibidores, vários outros estão em fase de testes clínicos (Tabela 1), mas ainda não foram aprovados (SÁNCHEZ-MARTíNEZ et al., 2019). 
Tabela 1 - Inibidores da CDK em desenvolvimento clínico.

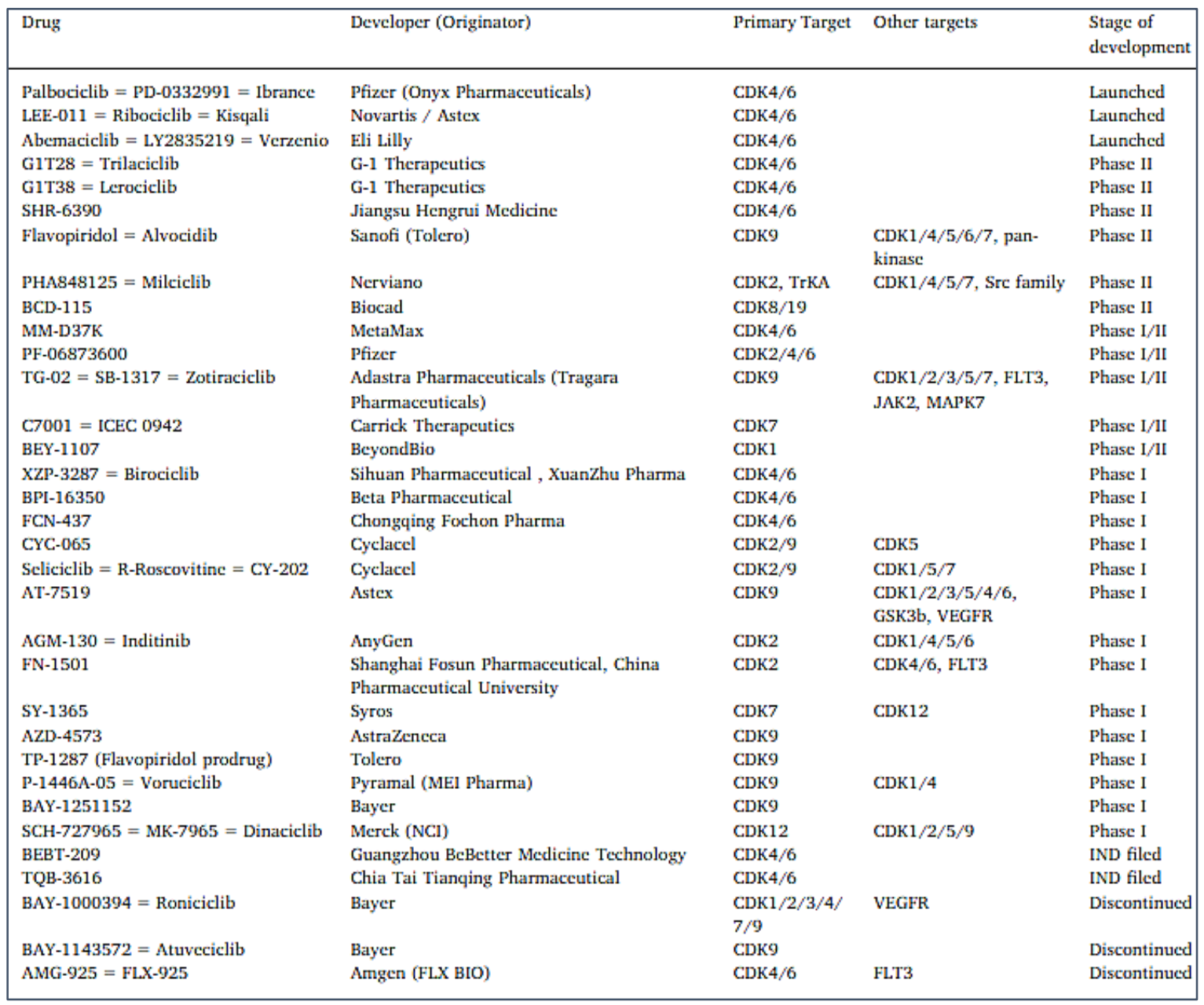

Fonte: SÁNCHEZ-MARTÍNEZ et al., 2019

\subsection{CDK11 - Do gene às isoformas}

A CDK11, originalmente conhecida como PITSLRE, foi descoberta em 1990 (BUNNELL et al., 1990). Atualmente são conhecidas mais de 20 isoformas de CDK11, as quais são expressas a partir de dois genes altamente homólogos encontrados na extremidade curta do cromossomo 1 (locus gênico 1p36.33), CDC2L1 e CDC2L2 conhecidos como CDK11 B e A, respectivamente (XIANG et al., 1994).

Ambos os genes possuem 21 éxons, sendo que em todos os RNA mensageiros (mRNAs) estão presentes os últimos 11 éxons. A isoforma CDK11p58 não é um produto de splicing, ela é codificada a partir de um local interno de entrada no ribossomo (IRES) (Figura 9). Já as isoformas de massa aparente de 110kDa referidas como CDK11p110, são produzidas pela combinação dos demais éxons e leva às isoformas de massas moleculares aparentes entre 60 e 110 kDa em SDS-PAGE (XIANG et al., 1994). Outra 
isoforma muito estudada é a CDK11p46, ela é gerada pela clivagem proteolítica das isoformas maiores por caspases 1 e 3 (Figura 9) e consiste principalmente do domínio quinase (FENG et al., 2005).

Um diagrama esquemático do gene completo e os elementos presentes nele podem ser observados na Figura 9.

Figura 9 - Diagrama esquemático do comprimento total da CDK11.

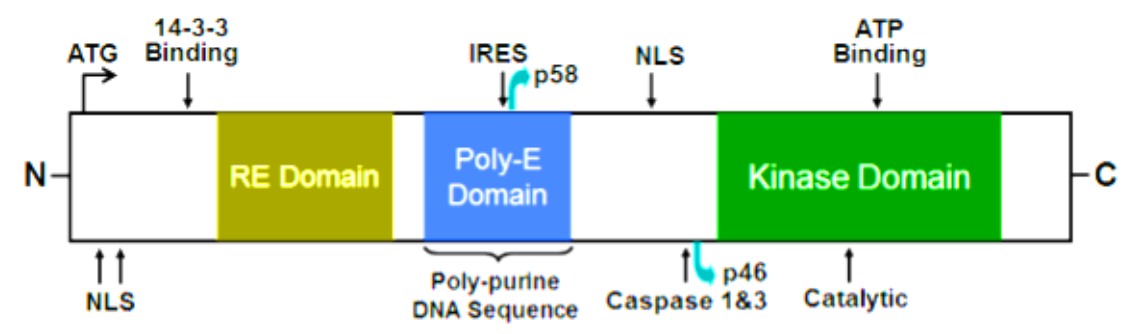

Fonte: ZHOU et al., 2015.

Considerando a tradução do gene completo, podemos dividi-la em duas regiões, a região reguladora (N-terminal) e a região catalítica (C-terminal) (ZHOU et al., 2015).

Conforme esquematizado na figura 9 na região $\mathrm{N}$-terminal temos:

- Sinal de localização nuclear (NLS) - pequena sequência de lisinas (K) ou argininas $(\mathrm{R})$ carregadas positivamente que direcionam a proteína para $\mathrm{o}$ núcleo celular.

- Sítio de ligação 14-3-3 - região de ligação consenso de proteínas de sinalização denominadas 14-3-3, que interagem com motivos específicos de fosfoserina ou treonina em várias proteínas.

- Domínio RE (região rica em arginina e glutamato) - ligados a associação com fatores de processamento de RNA.

- Domínio poli-E (região de poliglutamato) - potenciais domínios de interação citoesquelética.

Na região C-terminal temos o domínio quinase, responsável pela função quinase da CDK11.

A região C-terminal é conservada nas 20 isoformas da CDK11, há apenas 3 resíduos de aminoácidos diferentes no domínio quinase das isoformas CDK11A, quando comparadas as isoformas da CDK11B (Anexo 1). 
Na região do domínio quinase temos vários elementos característicos conservados nas CDKs que podem ser observados na Figura 10.

Figura 10 - Elementos de estrutura secundária do monômero da CDK2 (código PDB: 1hck, resolução 1,90 ̊̊) ATP (em hastes e esferas), N-terminal rico em fitas $\beta$ (cinza), a alça rica em glicina (verde), $\mathrm{C}$ - terminal rico em hélices $\alpha$ (rosa), hélice C, de sequência PSTAIRE (amarelo) e segmento de ativação ou alça T (azul).

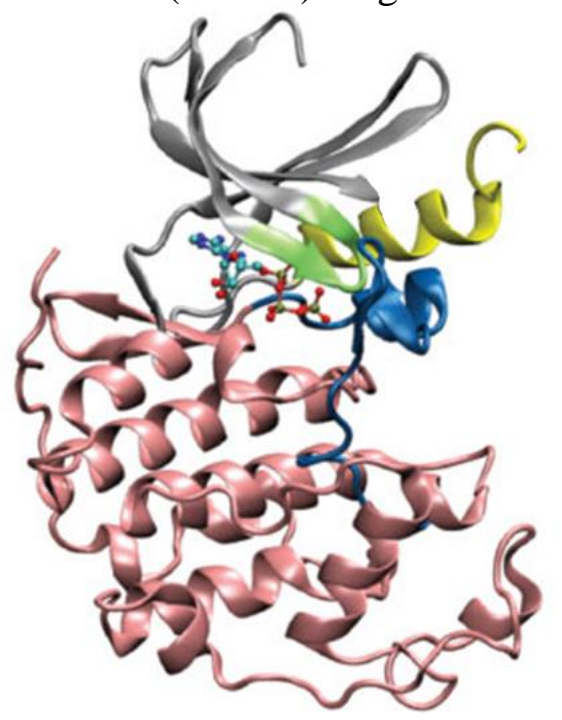

Fonte: GAHMEN, DE BONDT e KIM, 1996 modificada por SILVA et al., 2009.

Os principais elementos mostrados na Figura 10 são:

- Estrutura de dois domínios, um N-terminal rico em fitas $\beta$ (cinza) com uma alça rica em glicina (verde) e um C-terminal rico em hélices $\alpha$ (rosa).

- Sítio de ligação ao ATP em que o ATP está representado em hastes e esferas.

- Domínio de ligação a ciclina - hélice C (amarela).

- Alça T (azul) - segmento de ativação.

- Locais de fosforilação - envolvidos na ativação e repressão da atividade quinase (não representados na Figura 10).

$\mathrm{O}$ alinhamento da CDK2 com a isoforma 1A da CDK11 com as estruturas secundárias correspondentes podem ser observados no anexo 2. 


\subsection{CDK11 - Isoformas e suas funções}

Apesar de conhecidas 20 isoformas de CDK11, as mais estudadas são a CDK11p110 (transcricional), a CDK11p58 (mitótica) e a CDK11p46 (apoptótica).

\subsubsection{CDK11p110}

Parceira das ciclinas L1 e L2, as isoformas CDK11p110 abrangem a multiplicidade de isoformas geradas de 50 a $85 \mathrm{kDa}$, mas de peso aparente $110 \mathrm{kDa}$ (migração anômala em SDS-PAGE), que são produzidas pelo splicing alternativo (XIANG et al., 1994).

São proteínas nucleares expressas onipresente e constantemente ao longo do ciclo celular (LOYER et al., 1998) e atuam em diversos processos celulares (Figura 11), tais como:

- Na regulação da transcrição, em que já foi demostrado sua interação com vários fatores de iniciação e alongamento da transcrição, tais como o fator de alongamento 2 da polimerase de RNA (ELL2), o fator de transcrição IIF (TFIIF), fator de transcrição IIS (TFIIS) e com o complexo FACT (TREMBLEY et al., 2002). Também atua fosforilando alvos transcricionais, incluindo RNA polimerase (RNAPII) CTD (domínio C-terminal), processo ligado a montagem de fatores de poliadenilação e clivagem para regular o processamento final de transcritos de mRNA do HIV (vírus da imunodeficiência humana), conforme mostrado na figura 11-I (PAK et al., 2015).

- Na associação entre o núcleo do complexo Mediador e seu módulo de quinase, que contém o heterodímero CDK8 / ciclina C. Esta interação provou ser dependente da fosforilação das subunidades Med4 e Med27 por CDK11p110, conforme mostrado na figura 11-II (DROGAT et al., 2012).

- No splicing do pré-mRNA fosforila fatores responsáveis pela junção do pré-mRNA, como SC35 (Srfs2) e 9G8 (Srfs7), conforme mostrado na figura 11-III (LOYER et al., 1998; DICKINSON et al., 2002; HU et al., 2003; LOYER et al., 2008). 
Figura 11 - Processos celulares em que as isoformas de CDK11p110 atuam. - (I) Fosforilação da RNAPII CTD. (II) Associação entre o núcleo do complexo mediador e seu módulo de quinase

(III) Na fosforilação de fatores de splicing.

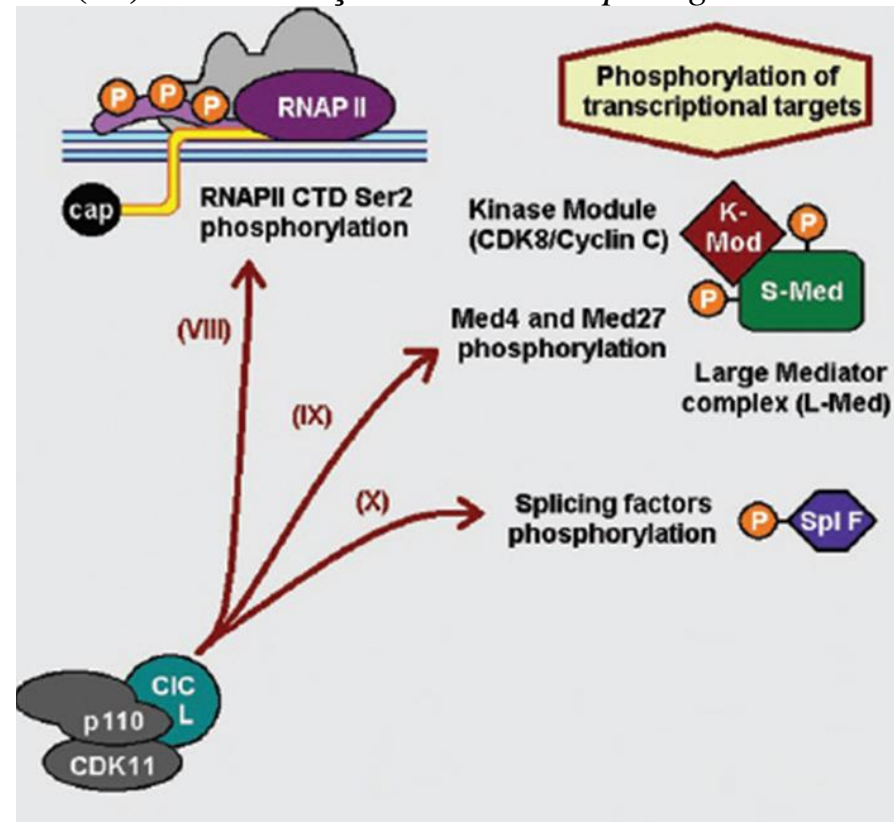

Fonte: Modificado de PAPARIDIS e CANDURI, 2018.

Além disso, agem como um regulador positivo da via de sinalização Hedgehogm, onde dá as células embrionárias informações que lhes permitem fazer o embrião desenvolver-se de maneira correta (EVANGELISTA et al., 2008), e como um modulador da cascata de sinalização de Wnt / $\beta$-catenina, onde atua regulando o desenvolvimento embrionário, proliferação e diferenciação celular (NAIK et al., 2009).

\subsubsection{CDK11p58}

Parceira das ciclinas L1, L2 e também da ciclina D3. Essa isoforma apenas é traduzida nas fases $\mathrm{G}_{2} / \mathrm{M}$ (TINTON et al., 2005.)

A CDK11p58 está envolvida na mitose e citocinese (CORNELIS et al., 2000) e foi mostrado que ela é essencial para maturação dos centrossomas, montagem do fuso mitótico e coesão da cromátide irmã, impedindo-a de se separar antes da anáfase (PETRETTI et al., 2006; HU et al., 2007). Sua depleção causa acúmulos de defeitos nas células filhas e desencadeia a apoptose ou catástrofe mitótica (HU et al., 2007). 
Já está bem caracterizado que o resíduo Thr370 da CDK11p58 é um local cuja autofosforilação causa a dimerização da CDK11p58 e que esse processo é essencial para a sua atividade quinase (Figura 12) (CHI et al., 2011).

Figura 12 - Autofosforilação e dimerização da CDK11p58

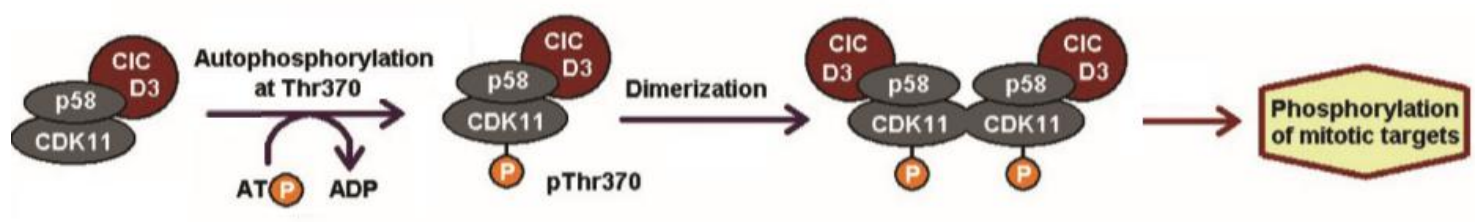

Fonte: Modificado de PAPARIDIS e CANDURI, 2018.

A CDK11p58 tem como um de seus substratos já conhecidos a quinase 1 ativada por p21 (PAK1). A função da CDK11p58 é fosforilar a PAK1 em Ser174 e assim promover seu recrutamento para o complexo motor da miosina V (KONG et al., 2009).

O receptor androgênico (AR) é outro alvo do complexo CDK11p58/ciclina D3. O complexo atua fosforilando o AR no resíduo de Ser308 $n$ vitro e in vivo, levando a atividade reprimida da unidade de ativação transcricional 1 do AR (TAU1) (ZONG et al. 2007).

\subsubsection{CDK11p46}

A isoforma CDK11p46 se liga as ciclinas L1 e L2 e é um fragmento C-terminal gerado pela clivagem das isoformas maiores por caspase 3 (Figura 13). Em células humanas sua expressão é ectópica e induz a apoptose (MIKOLAJCZYK e NELSON, 2004).

Em diversas linhagens celulares a ativação proteolítica da CDK11p46 foi observada durante a apoptose induzida (SHI et al., 2003; TANG, GURURAJAN e KIDD 1998; ARIZA et al., 1999).

Entre os alvos já identificados para a CDK11p46 o mais bem caracterizado é a fosforilação dos resíduos de Ser46 e Thr119 da subunidade p47 do fator de iniciação eucariótico eIF3 (eukaryotic initiation factor 3). Essas fosforilações fortalecem as interações com as subunidades principais do complexo, o que inibe a síntese de proteínas e estimula a degradação de mRNA (SHI et al., 2003; SHI, HERSHEY e NELSON, 2009). 
Ao gerar a isoforma CDK11p46, seu fragmento complementar, denominado CDK11p60 também é gerado. Importado para as mitocôndrias, CDK11p60 interrompe o potencial da membrana e induz a liberação do citocromo c, o que leva a ativação da caspase-3, fornecendo um feedback positivo a cascata de sinalização apoptótica (Figura 13) (FENG et al., 2005).

Figura 13 - Clivagem proteolítica da CDK11p110 em CDK11p46 e CDK11p60 no núcleo e atuação da CDK11p46 e da CDK11p60 no citoplasma.

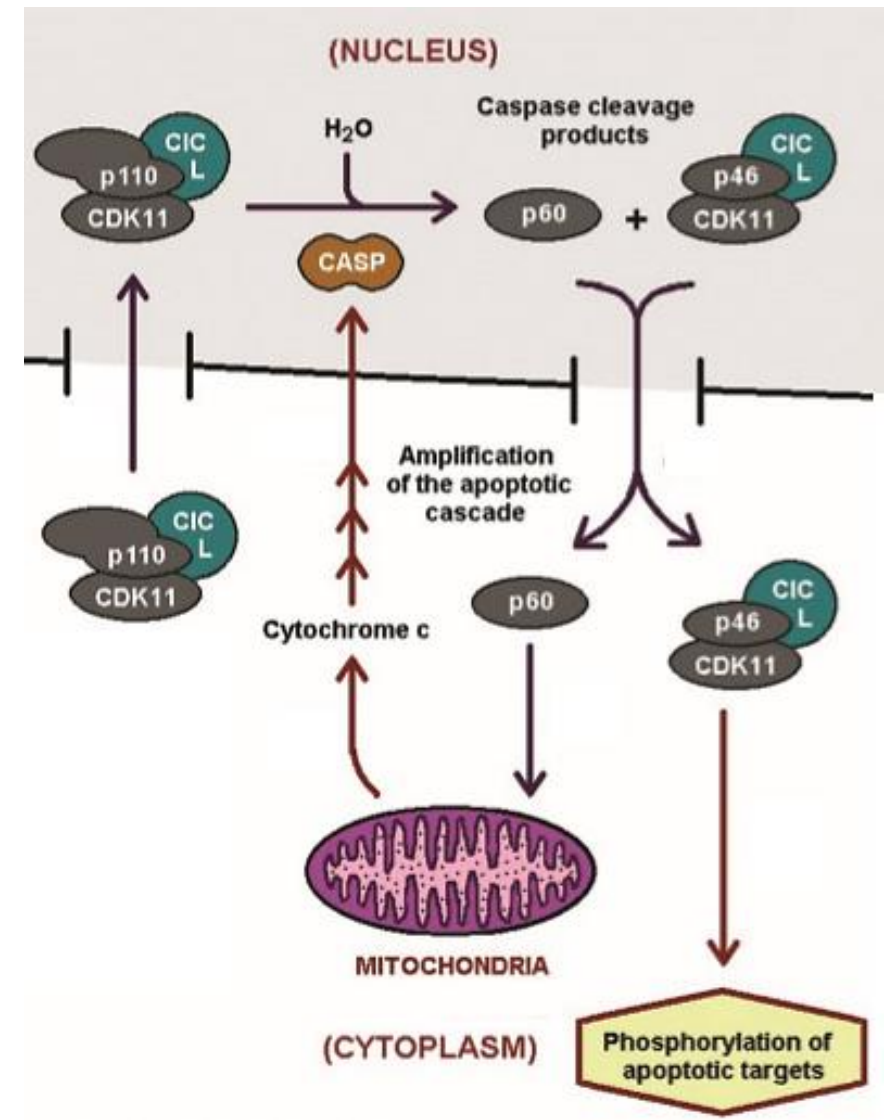

Fonte: Modificado de PAPARIDIS e CANDURI, 2018.

\subsection{CDK11 e o câncer}

Particularmente para a CDK11, estudos têm mostrado um papel importante desta no crescimento e na proliferação de cânceres, tais como, câncer de mama, de ovário, osteosarcoma, lipossarcoma, mieloma múltiplo, câncer de cólon, câncer cervical e outros (ZHOU et al., 2015; KREN et al., 2015; TIEDMANN et al., 2012; DUAN et al., 2012 e JIA et al., 2014). 
A tabela 2 resume os principais estudos envolvendo a CDK11 nos cânceres de mama, de ovário, osteossarcoma e lipossarcoma.

Tabela 2 - CDK11 e o câncer de mama, ovário, osteossarcoma e lipossarcoma.

\begin{tabular}{|c|c|c|c|c|}
\hline $\begin{array}{l}\text { TIPO DE } \\
\text { CÂNCER }\end{array}$ & $\begin{array}{c}\text { CORRELAÇÃO } \\
\text { ESTADO } \\
\text { CLÍNICO E } \\
\text { EXPRESSÃO DA } \\
\text { CDK11 }\end{array}$ & $\begin{array}{c}\text { KNOCKDOWN } \\
\text { IN VITRO }\end{array}$ & $\begin{array}{c}\text { KNOCKDOWN } \\
\text { IN VIVO }\end{array}$ & OUTROS \\
\hline $\begin{array}{c}\text { Câncer de } \\
\text { mama triplo } \\
\text { negativo } \\
\text { (TNBC) }\end{array}$ & $\begin{array}{l}\text { A alta expressão } \\
\text { da CDK11 foi } \\
\text { associada a um } \\
\text { mau prognóstico } \\
\text { clínico. }\end{array}$ & $\begin{array}{c}\text { Inibiu a } \\
\text { proliferação } \\
\text { celular e induziu } \\
\text { a apoptose. }\end{array}$ & $\begin{array}{c}\text { Causou } \\
\text { encolhimento do } \\
\text { tumor no } \\
\text { xenoenxerto } \\
\text { MDA-MB-231. }\end{array}$ & $\begin{array}{l}\text { CDK11 mostrou } \\
\text { ser crítica para a } \\
\text { sobrevivência e } \\
\text { proliferação de } \\
\text { células de } \\
\text { TNBC. }\end{array}$ \\
\hline $\begin{array}{l}\text { Câncer de } \\
\text { ovário }\end{array}$ & $\begin{array}{l}\text { A superexpressão } \\
\text { da CDK11 em } \\
\text { câncer de ovário é } \\
\text { associada a } \\
\text { progressão maligna }\end{array}$ & $\begin{array}{c}\text { Diminuiu a } \\
\text { proliferação } \\
\text { celular e induziu } \\
\text { apoptose }\end{array}$ & $\begin{array}{c}\text { Reduziu o } \\
\text { crescimento do } \\
\text { tumor em um } \\
\text { modelo de } \\
\text { xenoenxerto }\end{array}$ & $\begin{array}{c}\text { Seu silenciamento } \\
\text { in vitro aumentou } \\
\text { o efeito citotóxico } \\
\text { do paclitaxel }\end{array}$ \\
\hline Osteossarcoma & $\begin{array}{l}\text { A alta expressão da } \\
\text { CDK11 foi } \\
\text { associada a uma } \\
\text { menor sobrevida } \\
\text { dos pacientes }\end{array}$ & $\begin{array}{c}\text { Inibiu o } \\
\text { crescimento } \\
\text { celular e induziu } \\
\text { a apoptose }\end{array}$ & $\begin{array}{c}\text { Reduziu o } \\
\text { crescimento do } \\
\text { tumor em modelo } \\
\text { de xenoenxerto } \\
\text { subcutâneo de } \\
\text { osteossarcoma. }\end{array}$ & $\begin{array}{c}\text { A CDK11 } \\
\text { mostrou } \\
\text { aumentar a } \\
\text { ativação } \\
\text { transcricional do } \\
\text { gene do receptor } \\
\text { de andrógeno } \\
\text { (RA) em linhas } \\
\text { celulares }\end{array}$ \\
\hline Lipossarcoma & $\begin{array}{l}\text { CDK11 foi mais } \\
\text { expressa em células } \\
\text { de lipossarcoma do } \\
\text { que em tecidos do } \\
\text { lipoma benigno }\end{array}$ & $\begin{array}{c}\text { Diminuiu a } \\
\text { proliferação } \\
\text { celular e induziu } \\
\text { apoptose }\end{array}$ & $\begin{array}{c}\text { Não foi } \\
\text { encontrado } \\
\text { estudos } \\
\text { in vivo em } \\
\text { lipossarcoma }\end{array}$ & $\begin{array}{l}\text { Seu } \\
\text { silenciamento in } \\
\text { vitro aumentou o } \\
\text { efeito citotóxico } \\
\text { da doxorrubicina }\end{array}$ \\
\hline
\end{tabular}

Fonte: Autoria própria.

\subsubsection{CDK11 em câncer de mama}

Em câncer de mama triplo negativo (triple negative breast cancer - TNBC), CDK11 é altamente expressa e se mostrou essencial para a manutenção da característica 
agressiva nesse tipo de câncer, pois se correlacionou com um estágio TNM avançado, fraca diferenciação e mau prognóstico clínico (ZHOU et al., 2015 e KREN et al., 2015).

A análise imuno-histoquímica dos tecidos mostrou que em comparação com o tecido normal, $100 \%$ dos tumores apresentaram coloração positiva com alta intensidade nuclear para CDK11. E o silenciamento da sua expressão in vitro, por siRNA, mostrou inibir a proliferação celular e induzir a apoptose (KREN et al., 2015).

O tratamento com nanocápsulas de tenfibgen-siCDK11, in vivo, causou encolhimento do tumor no xenoenxerto MDA-MB-231 (linhagem celular de câncer de TNBC altamente agressiva, invasiva e pouco diferenciada), perda de proliferação celular e diminuição da expressão de genes direcionados (KREN et al., 2015).

Esses resultados sugerem que a CDK11 é crítica para a sobrevivência e proliferação de células de TNBC, destacando essa proteína como um alvo promissor para o desenvolvimento de inibidores que atuem contra essa doença.

\subsubsection{CDK11 em câncer de ovário}

A CDK11 também foi identificada como sendo superexpressa em câncer de ovário e associada a progressão maligna, sendo mediadora no crescimento e na proliferação celular. Nesse cenário, seu silenciamento por siRNA (small interfering RNA) sintético ou shRNA (small hairpin RNA) lentiviral diminuiu a proliferação celular e induziu apoptose, além de aumentar o efeito citotóxico do paclitaxel. In vivo, a administração sistêmica de CDK11 siRNA reduziu o crescimento do tumor em um modelo de xenoenxerto (LIU et al., 2016).

\subsubsection{CDK11 em osteossarcoma}

Resultados semelhantes foram encontrados para osteossarcoma, quando DUAN et al., (2012) identificou a CDK11 como essencial para a sobrevivência de células de osteossarcoma, pois essas células exibiram altos níveis de expressão de CDK11, e o knockdown da CDK11 inibiu o crescimento celular e induziu apoptose dessas células. Também foi demostrado que a administração sistêmica in vivo de siRNA reduziu o crescimento do tumor em um modelo de xenoenxerto subcutâneo de osteossarcoma (DUAN et al., 2012). 
Além disso, a alta expressão dessa proteína foi associada a uma menor sobrevida dos pacientes com osteossarcoma, quando comparado aos pacientes com baixa expressão dela (DUAN et al., 2012).

Utilizando o sistema repetitivo palindrômico-Cas9 (CRISPR-Cas9) para silenciar o DNA endógeno da CDK11 observou-se que o nocaute do CDK11 reduziu significativamente a viabilidade, proliferação e migração celular, além de causar morte celular induzida (FENG et al., 2015).

A CDK11 também mostrou aumentar a ativação transcricional do gene do receptor androgênico em linhagens celulares de osteossarcoma em estudo que identificou o receptor androgênico como potencial marcador prognóstico e alvo oncogênico no osteossarcoma (LIAO et al., 2017).

\subsubsection{CDK11 em lipossarcoma}

A análise imuno-histoquímica de tecido de lipossarcoma mostrou que CDK11 foi mais expressa do que em tecidos do lipoma benigno. Além disso, o knockdown por siRNA sintético ou shRNA lentiviral diminuiu a proliferação celular, induziu apoptose e aumentou o efeito citotóxico da doxorrubicina (JIA et al., 2014).

\subsubsection{CDK11 em outros tipos de câncer}

Além dos cânceres já citados, a CDK11 atua no câncer de cólon como modulador positivo da via Wnt / $\beta$-catenina (NAIK et al., 2009). Em câncer cervical mostrou promover nas células cancerígenas a maturação de centrossomas e morfogênese do fuso bipolar. E em leucemia mieloide aguda, por nocaute baseado em CRISPR com RNA de interferência (RNAi), a eliminação da CDK11 mostrou inibir o crescimento em células derivadas de leucemia mieloide aguda (HOUSDEN et al., 2015).

Em mieloma múltiplo identificaram a CDK11 como uma quinase vulnerável e propuseram a sua inibição como uma nova estratégia terapêutica. Além disso, o gene da CDK11 mostrou ser um fator crítico de sobrevivência em células de mieloma múltiplo e a expressão de CDK11 foi significativamente aumentada em tecidos primários de 
mieloma múltiplo quando comparados aos tecidos primários humanos normais (TIEDMANN et al., 2012).

O esquema geral do papel da CDK11 em câncer de cólon, cervical, leucemia mieloide aguda e mieloma múltiplo pode ser observado na Figura 14.

Figura 14 - Estudos da CDK11 em câncer de cólon, cervical, leucemia mieloide aguda e mieloma múltiplo.
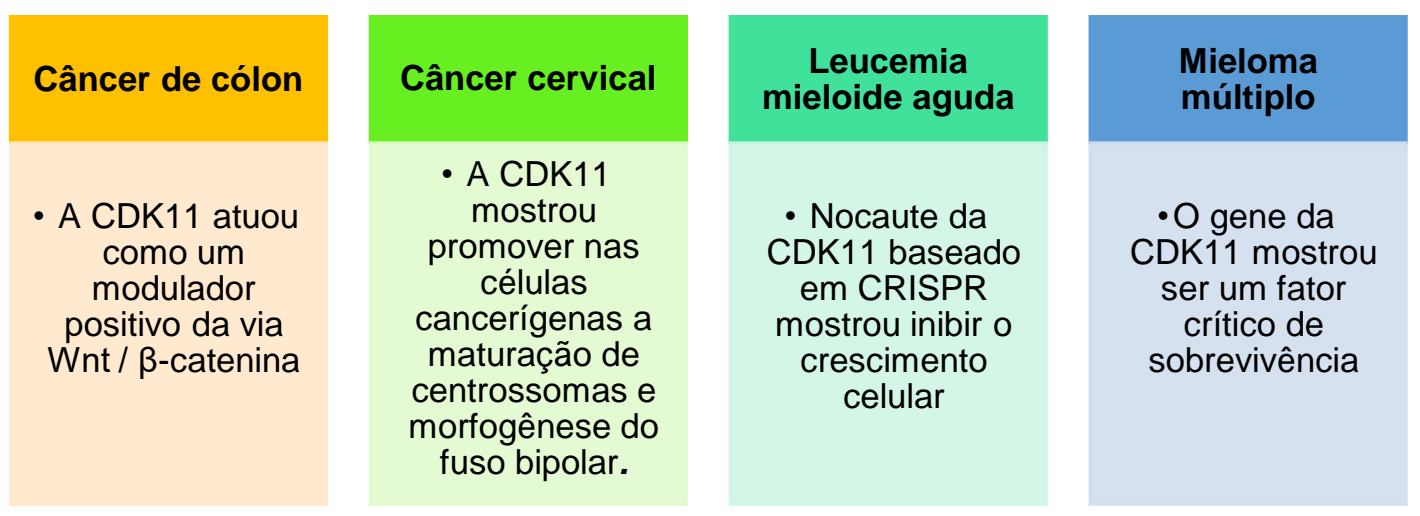

Fonte: Autoria própria.

Considerando todos esses estudos tem-se que CDK11 geralmente é superexpressa e/ou ativada em vários tipos de câncer e sua regulação negativa pode ser promissora no tratamento desses tipos de câncer.

\subsection{CDK11 em outras doenças}

Alguns estudos abordaram o papel da CDK11 em outras doenças, tais como no HIV, em que a CDK11p110 demonstra ter o papel de regular a clivagem e a poliadenilação de múltiplos transcritos virais, sendo essencial na co-transcrição do mRNA do HIV (PAK et al., 2015).

O mecanismo proposto é que CDK11p110 se associa com o TREX/THOC onde atua na fosforilação da RNAPII, o que aumenta a poliadenilação no terminal 3' do RNA do HIV, e leva a maior estabilidade dos transcritos de mRNA e sua exportação para o citosol (CARY, FUJINAGA e PETERLIN, 2016).

Além de exercer funções importantes no HIV, alguns estudos mostram que a CDK11 também tem papéis importantes em funções neurais. O complexo CDK11p58ciclina D3, por exemplo, atua na repressão da proliferação de células de Schwann, tipo 
de célula que forma a mielina que envolve os axónios dos neurônios, isolando os nervos eletricamente e facilitando a transmissão do impulso nervoso (DUAN et al., 2010). Nas funções anormais das lesões da medula espinhal em ratos foi observado aumento drástico dos níveis de transcrição da CDK11p58, em relação ao grupo controle (JI et al., 2008).

Foi observado também que a superexpressão de CDK11p58 promove a apoptose neural em células PC12 e seu knockdown reprimiu a apoptose (LIU et al., 2013).

Além disso, foi observado o aumento da expressão citoplasmática de CDK11, no processo celular da doença de Alzheimer (DA) (BAJIC et al., 2011). Foi demonstrado que a CDK11 está envolvida na resposta inflamatória mediada por astrócitos na DA, e esse processo tem sido associado como um gatilho para ativação da cascata neurodegenerativa que leva a morte neuronal, com o avanço da idade (BAJIC et al., 2015), o que torna a CDK11 muito importante no desenvolvimento de fármacos para DA.

A seguir, na Figura 15, podemos observar um esquema geral das diversas funções da CDK11, conforme relatado nos tópicos anteriores.

Figura 15 - Diagrama esquemático das diversas funções exercidas pela CDK11.

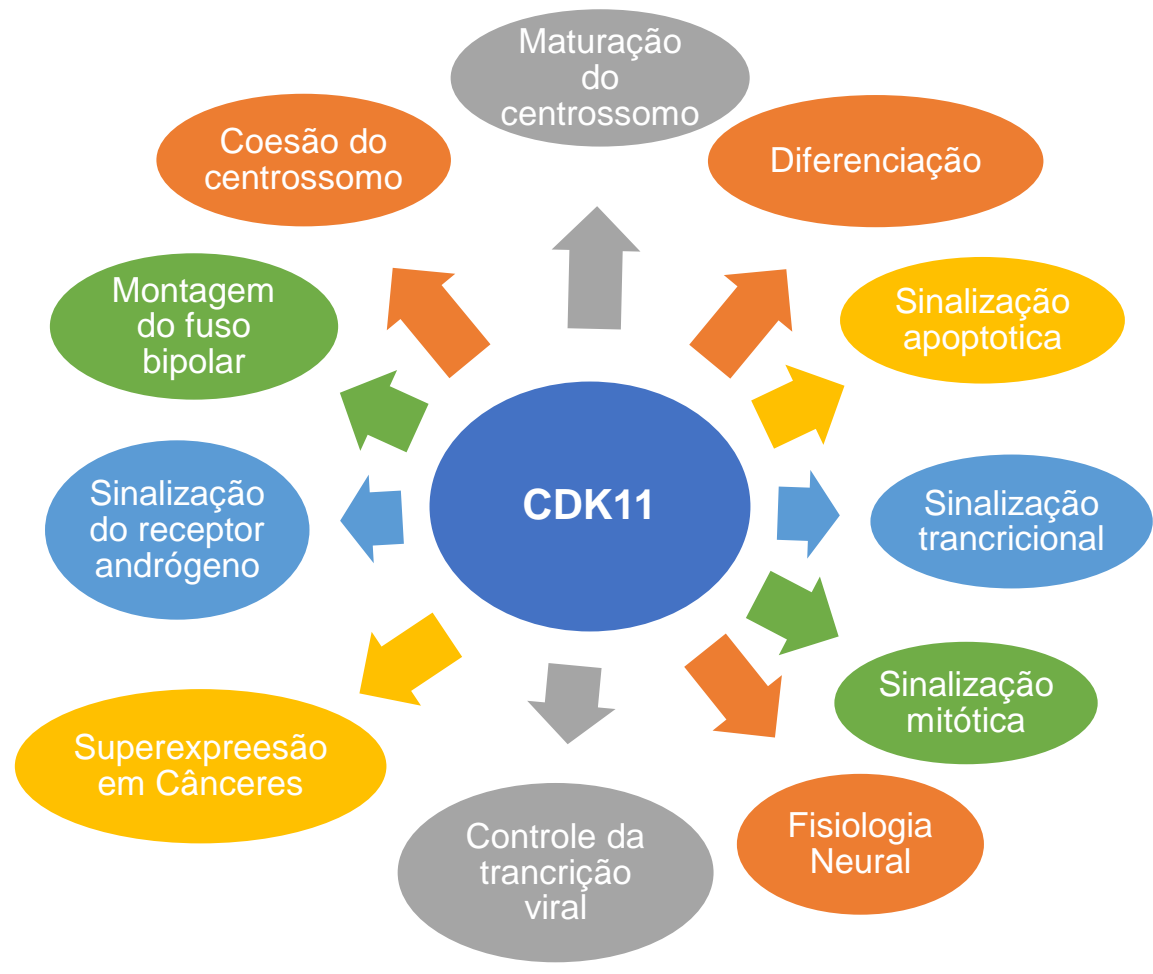

Fonte: Autoria própria. 


\subsection{Inibidores de CDK11}

Atualmente, já se conhecem 20 isoformas da CDK11, no entanto a proteína não possui estrutura cristalográfica depositada no PDB (Protein Data Bank) e a maioria dos estudos com a CDK11 são relacionados aos aspectos genéticos e funcionais dessa proteína, sendo pouca atenção dada ao seu estudo estrutural para o desenvolvimento de inibidores específicos (ZHOU et al., 2015 e PAPARIDIS e CANDURI, 2018).

O estudo estrutural de uma proteína é de suma importância no que se refere ao entendimento de sua estrutura para o desenvolvimento de inibidores mais seletivos, e contribui com dados fundamentais para estudos de relação estrutura-atividade.

Cee et al., (2009) mostraram que cortistatina A liga-se ao sítio de ligação do ATP da CDK11 com uma constante de dissociação $\left(\mathrm{K}_{\mathrm{d}}\right)$ de $10 \mathrm{nM}$ (CEE et al., 2009). Em 2019, considerando que mais de noventa por cento dos medicamentos testados em ensaios clínicos oncológicos não recebem aprovação da FDA dos EUA, Lin et al., (2019) usaram a mutagênese CRISPR-Cas9 para investigar vários medicamentos contra o câncer (LIN et al. 2019).

Após silenciamento do potencial alvo do fármaco, caso a substância quimicamente ativa continuasse a agir, tinha-se um indicativo que esses compostos matam células por efeitos fora do alvo. Ao aplicar essa estratégia, descobriram que o agente anticâncer OTS964 era um inibidor putativo de PBK e seu verdadeiro alvo era a CDK11, com a qual interagia com um $\mathrm{K}_{\mathrm{d}}$ de $40 \mathrm{nM}$ (LIN et al. 2019).

Focando nesse inibidor, pois este exibia potência nanomolar em vários tipos de câncer e afetava a progressão mitótica (antimitóticos são, historicamente, agentes oncológicos de alto sucesso), descobriram que os clones que adquiriram resistência a este fármaco permaneciam sensíveis ao paclitaxel, o que possibilitaria ainda o tratamento do paciente (LIN et al. 2019).

Avaliando as potenciais mutações nesses clones resistentes, observaram que em todos os clones resistentes, um resíduo de glicina da CDK11 foi trocado por um resíduo de serina (Figura 16) e que as construções usadas para induzir a mutação $G \rightarrow S$ em $x D F G$, foi suficiente para conferir resistência ao OTS964. 
Figura 16 - Construções usadas para introduzir a mutação $G \rightarrow S$ (glicina para serina) indicada em vermelho em xDFG antes (CDK11B) e após mutação (ssODN) mediado por CRISPR. Local da clivagem de Cas9 (seta amarela) e mutações silenciosas (destacadas em azul).

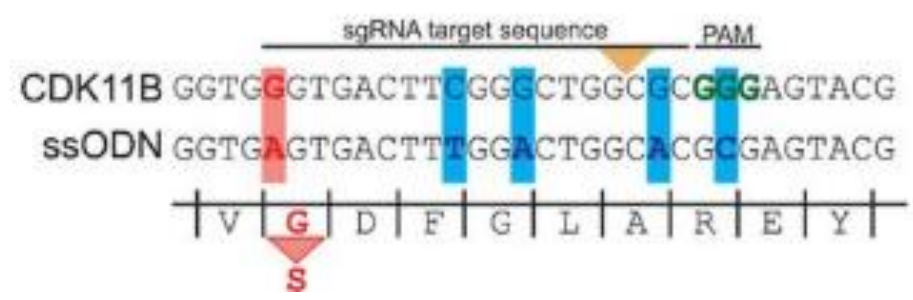

Fonte: LIN et al., 2019.

Alinhando as 20 CDKs conhecidas, descobriram que apenas a CDK11 possuía essa glicina imediatamente a montante do motivo DFG (local de coordenação do magnésio) e que as outras 19 CDKs possuíam um resíduo de alanina (Figura 17).

Figura 17-Alinhamento das CDKs, em azul, a posição do resíduo de glicina nas CDKs11A e B, diferente das demais CDKs. Em vermelho destaca-se o loop T.

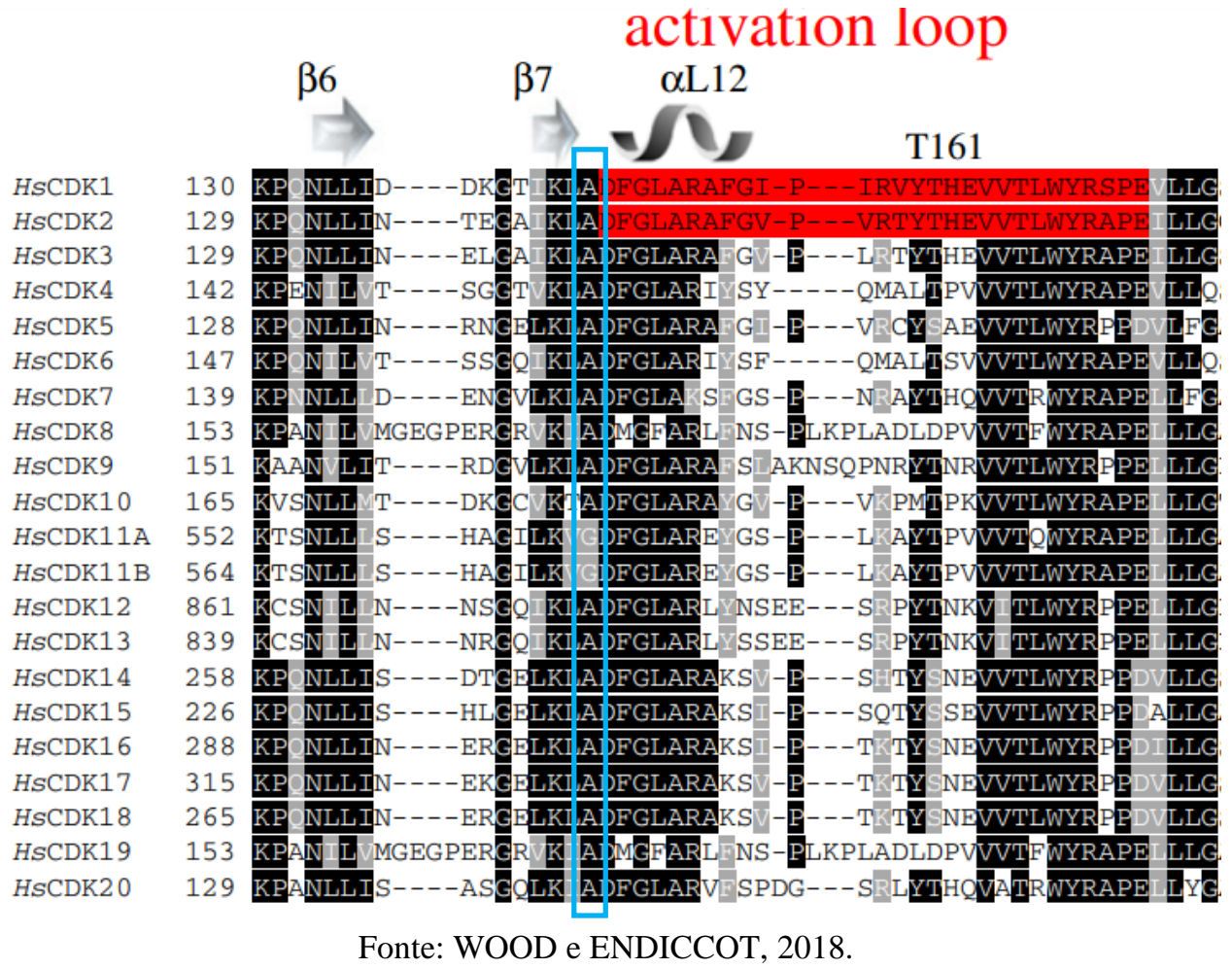

Lin et al., (2019) avaliaram um clone mutante da CDK11 (G $\rightarrow$ A) (resíduo similar as outras CDKs) e observaram que nesse clone com alanina havia a diminuição da eficácia do inibidor OTS964 (LIN et al. 2019). 
Por fim, os resultados indicaram que o potencial inibidor OTS964 atua na CDK11, e sua especificidade é conferida pelo motivo xDFG. Como vários tipos de câncer são dependentes de CDK11, avaliar os ensaios para OTS964 considerando como alvo a CDK11 pode diminuir o número de terapias testadas, e assim direcionar melhor cada ensaio (LIN et al. 2019).

Todos esses trabalhos mostram a importância do estudo da CDK11 e de potenciais inibidores dessa proteína para futuros tratamentos direcionados para sua inibição.

\section{OBJETIVOS}

\subsection{Objetivo Principal}

Clonar, expressar, purificar e caracterizar a proteína recombinante CDK11 $\Delta$ obtida em sistema de expressão heterólogo (E. coli).

\subsection{Objetivos Específicos}

- Obter o domínio quinase da CDK11 humana, aqui denominada $\operatorname{CDK} 11 \Delta$, a partir da expressão heteróloga em E. coli. com pureza adequada para seu estudo por métodos biofísicos.

- Realizar ensaios biofísicos com a CDK11 espectrofluorimetria, a fim de estudar a proteína obtida quanto a sua estrutura secundária, estabilidade de armazenamento a $4^{\circ} \mathrm{C}$, temperatura de desenovelamento térmico, desenovelamento frente ao agente desnaturante ureia e estudos de interação com seu ligante natural ATP e o potencial inibidor roscovitina.

- Estudar por métodos de bioinformática a interação entre o ATP e CDK11 $\Delta$ e entre roscovitina e CDK11 $\Delta$ utilizando modelagem e dinâmica molecular.

- Realizar ensaios de cristalização da CDK11

- Realizar estudos de interação dos potenciais inibidores, 3a, 3b e 3f, do projeto em parceria com a professora Dra. Fernanda Andreia Rosa, da UEM, para determinar os valores das constantes de dissociação $\left(\mathrm{K}_{\mathrm{d}}\right)$ desses compostos com a $\mathrm{CDK} 11 \Delta$. 


\section{MATERIAL E MÉTODOS}

\subsection{Clonagem da CDK11 $\Delta$ em pET28a}

\subsubsection{Planejamento do clone da CDK11 $\Delta$}

Devido aos resultados anteriores, obtidos pelo grupo de pesquisa, terem mostrado a impossibilidade de expressar de forma heteróloga a CDK11p110 em sistema bacteriano, análises de bioinformática foram realizadas a fim de adquirir uma forma encurtada, referente ao domínio quinase da CDK11, passível de superexpressão em $E$. coli. A mesma estratégia foi utilizada para outras quinases maiores, tais como a CDK13 (GREIFENBERG et al., 2016).

A sequência da isoforma escolhida no banco de dados GenBank (https://www.ncbi.nlm.nih.gov/nuccore/) foi a de código NM_024011.3 (CDK11 isoforma1A). Após convertida na sequência de aminoácidos (https://web.expasy.org/translate/), a estrutura secundária da CDK11 foi analisada utilizando a ferramenta PSIPRED (http://bioinf.cs.ucl.ac.uk/psipred/), que nos oferece um mapa da estrutura secundária evidenciando regiões desordenadas na cadeia polipeptídica. O resultado está representado na Figura 18, onde é possível observar a presença de regiões desordenadas no início e no final da cadeia. Estas regiões possivelmente ganham estrutura tridimensional quando da presença das proteínas de interação na célula, que corroborarão para a função celular. Porém, essas regiões não são essenciais para a caracterização do domínio quinase da CDK11.

Figura 18 - Análise da cadeia polipeptídica da CDK11 utilizando o PSIPRED.

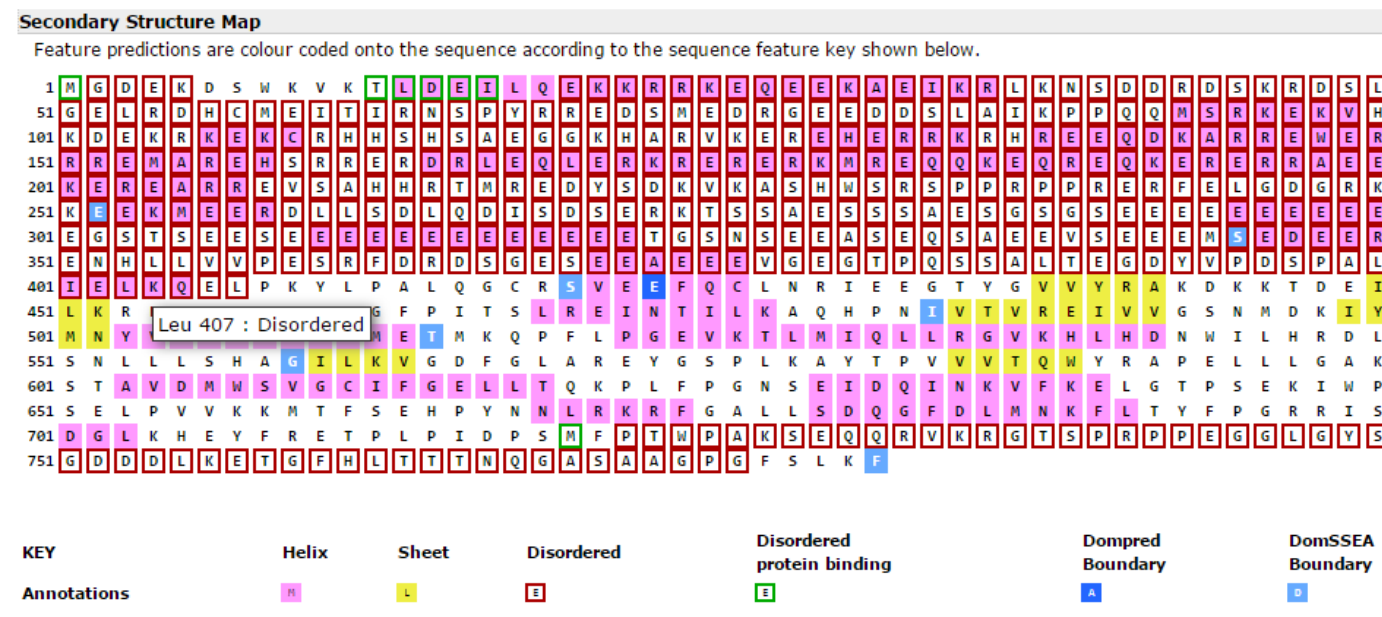

FONTE: http://bioinf.cs.ucl.ac.uk/psipred/. 
Essas regiões foram então removidas do cDNA (complementary DNA), o que resultou na superexpressão de uma proteína de $36 \mathrm{kDa}$, equivalente ao domínio quinase.

O cDNA foi submetido a análise para verificar a presença de códons raros, utilizando o programa SVKDIPMPPS-RARECODON (http://svkdipmpps-rarecodonanalysis.blogspot.com.br/). Conforme mostrado na figura 19, há 35 códons raros, os quais foram substituídos por códons comuns em E. coli, sem alterar a sequência da cadeia polipeptídica da proteína, no momento da expressão heteróloga. Adicionalmente, sítios de restrição para as enzimas $N c o$ I e XhoI foram incluídos nas extremidades 5’e $3^{\prime}$ do cDNA, respectivamente.

Figura 19 - Análise de códons raros para expressão de CDK11 1 em E. coli.

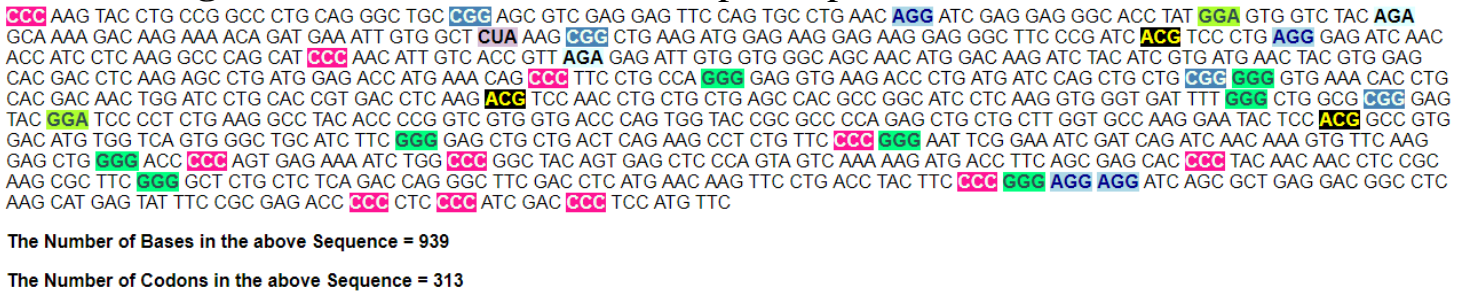

FONTE: http://svkdipmpps-rarecodon-analysis.blogspot.com.br/

Na confecção dos primers foram inseridos os mesmos sítios de restrição para as enzimas NcoI e XhoI (Figura 20). A análise dos primers foi realizada utilizando o IDTDNA (https://www.idtdna.com/calc/analyzer), considerando suas características quanto a formação de hairpin, temperatura de anelamento e porcentagem de CG.

Figura 20 - Primers desenhados para amplificação do cDNA da CDK11.

Primer direto: 5’ATACCATGGGCTGCCGTAGCGTCGAG 3’ 74,8 ${ }^{\circ} \mathrm{C}, 61,5 \% \mathrm{CG}$

Primer reverso: 5’ATACTCGAGGAACATGGACGGGTCGATC $3^{\prime} 72,5^{\circ} \mathrm{C}, 53,6 \% \mathrm{CG}$

Fonte: Autoria própria.

O vetor escolhido para clonagem foi o pET28a e a sequência final do recombinante pode ser observada na Figura 21. 
Figura 21 - Sequência do cDNA da CDK11 com os sítios da NcoI e XhoI nas extremidades 5'e 3', respectivamente. A sequência referente a cauda de histidina e o códon de terminação aparecem ao final da sequência.

5'...CCATGGGCTGCCGTAGCGTCGAGGAGTTCCAGTGCCTGAACCGTATCGAGGA GGGCACCTATGGCGTGGTCTACCGTGCAAAAGACAAGAAAACAGATGAAATTGTG GCTCTGAAGCGTCTGAAGATGGAGAAGGAGAAGGAGGGCTTCCCGATCACCTCCC TGCGTGAGATCAACACCATCCTCAAGGCCCAGCATCCGAACATTGTCACCGTTCGT GAGATTGTGGTGGGCAGCAACATGGACAAGATCTACATCGTGATGAACTACGTGG AGCACGACCTCAAGAGCCTGATGGAGACCATGAAACAGCCGTTCCTGCCAGGCGA GGTGAAGACCCTGATGATCCAGCTGCTGCGTGGCGTGAAACACCTGCACGACAAC TGGATCCTGCACCGTGACCTCAAGACCTCCAACCTGCTGCTGAGCCACGCCGGCAT CCTCAAGGTGGGTGATTTTGGCCTGGCGCGTGAGTACGGCTCCCCTCTGAAGGCCT ACACCCCGGTCGTGGTGACCCAGTGGTACCGCGCCCCAGAGCTGCTGCTTGGTGC CAAGGAATACTCCACCGCCGTGGACATGTGGTCAGTGGGCTGCATCTTCGGCGAG CTGCTGACTCAGAAGCCTCTGTTCCCGGGCAATTCGGAAATCGATCAGATCAACA AAGTGTTCAAGGAGCTGGGCACCCCGAGTGAGAAAATCTGGCCGGGCTACAGTGA GCTCCCAGTAGTCAAAAAGATGACCTTCAGCGAGCACCCGTACAACAACCTCCGC AAGCGCTTCGGCGCTCTGCTCTCAGACCAGGGCTTCGACCTCATGAACAAGTTCCT GACCTACTTCCCGGGCCGTCGTATCAGCGCTGAGGACGGCCTCAAGCATGAGTATT TCCGCGAGACCCCGCTCCCGATCGACCCGTCCATGTTCCTCGAGCACCACCACCA CCACCACTGA....

XhoI His Tag STOP Codon

Fonte: Autoria própria.

A figura 22 mostra o alinhamento das sequências da CDK11 e da CDK11 $\Delta$. Podem ser observados o domínio de ligação arginina/ácido glutâmico (RE domínio) (em verde) e o domínio de ácido-poliglutâmico (poli-E-domínio) (em azul), os quais foram excluídos da CDK11 1 para estudo do domínio quinase (em vermelho).

Figura 22 - Alinhamento de sequências da CDK11 em CDK11 $\Delta$ evidenciando os domínios RE (em verde) domínio poli E (em azul) e o domínio quinase (Gly416-Phe720) (em vermelho).

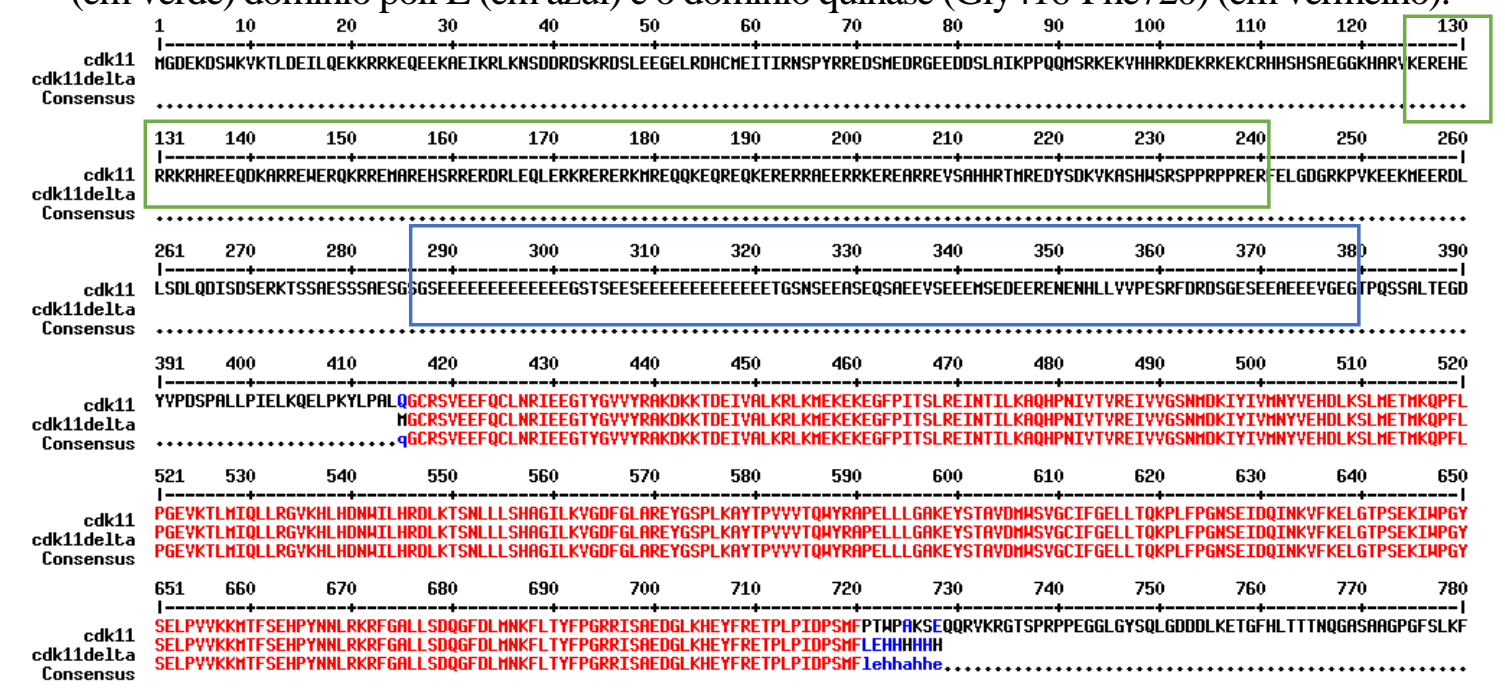

Fonte: Autoria própria. 


\subsubsection{Amplificação do cDNA da CDK11 $\Delta$}

Após aquisição dos primers e do cDNA referente a $\operatorname{CDK} 11 \Delta$, foram feitas 10 variações nas condições de PCRs a fim de amplificar o cDNA alvo (Tabela 3). O melhor resultado foi obtido no PCR3, conforme destacado em vermelho na Tabela 3.

Tabela 3 - Variação das condições do PCR para amplificação do cDNA da CDK11 $\Delta$.

\begin{tabular}{|c|c|c|c|c|c|c|c|c|c|c|}
\hline REAGENTE & $\begin{array}{c}\text { PCR } \\
1 \\
(\mu \mathrm{L})\end{array}$ & $\begin{array}{c}\text { PCR } \\
2 \\
(\mu \mathrm{L})\end{array}$ & $\begin{array}{c}\text { PCR } \\
\mathbf{3} \\
(\mu \mathrm{L})\end{array}$ & $\begin{array}{c}\text { PCR } \\
4 \\
(\mu \mathrm{L})\end{array}$ & $\begin{array}{c}\text { PCR } \\
5 \\
(\mu \mathrm{L})\end{array}$ & $\begin{array}{c}\text { PCR } \\
6 \\
(\mu \mathrm{L})\end{array}$ & $\begin{array}{c}\text { PCR } \\
7 \\
(\mu \mathrm{L})\end{array}$ & $\begin{array}{c}\text { PCR } \\
8 \\
(\mu \mathrm{L})\end{array}$ & $\begin{array}{c}\text { PCR } \\
9 \\
(\mu \mathrm{L})\end{array}$ & $\begin{array}{c}\text { PCR } \\
10 \\
(\mu \mathrm{L})\end{array}$ \\
\hline $\mathrm{H}_{2} \mathrm{O}$ mili $\mathbf{Q}$ & 32,1 & 31,1 & 27,1 & 15,8 & 16 & 15,0 & 15,8 & 15,0 & 15,5 & 15,0 \\
\hline $\begin{array}{c}\text { HF Phusion } \\
\text { Buffer } \\
(5 x)\end{array}$ & 10 & 10 & 10 & 5 & 5 & 5 & $\mathrm{X}$ & $\mathrm{X}$ & 5 & 5 \\
\hline $\begin{array}{l}\text { CG Phusion } \\
\text { Buffer }(5 x)\end{array}$ & $\mathrm{X}$ & $\mathrm{X}$ & $\mathrm{X}$ & $\mathrm{X}$ & $\mathrm{X}$ & $\mathrm{X}$ & 5 & 5 & $\mathrm{X}$ & $\mathrm{X}$ \\
\hline $\begin{array}{c}\text { dNTPs } \\
(10 \mathrm{mM})\end{array}$ & 1 & 2 & 1 & 0,5 & 0,5 & 0,5 & 0,5 & 0,5 & 0,5 & 0,5 \\
\hline $\begin{array}{c}\mathrm{MgCl}_{2} \\
(25 \mathrm{mM})\end{array}$ & 0,4 & 0,4 & 0,4 & 0,2 & $\mathrm{X}$ & 0,2 & 0,2 & 0,2 & 0,2 & 0,2 \\
\hline DMSO & $X$ & $\mathrm{X}$ & $X$ & $\mathrm{X}$ & $\mathrm{X}$ & 0,75 & $\mathrm{X}$ & 0,75 & $\mathrm{X}$ & $X$ \\
\hline $\begin{array}{c}\text { Primer Rv } \\
(\mathbf{1 0} \mu \mathrm{M})\end{array}$ & 2,5 & 2,5 & 5 & 1,25 & 1,25 & 1,25 & 1,25 & 1,25 & 1,25 & 1,25 \\
\hline $\begin{array}{c}\text { Primer Fw } \\
(10 \mu M)\end{array}$ & 2,5 & 2,5 & 5 & 1,25 & 1,25 & 1,25 & 1,25 & 1,25 & 1,25 & 1,25 \\
\hline $\begin{array}{c}\text { DNA } \\
(20 \mathrm{ng} / \mu \mathrm{L})\end{array}$ & 1 & 1 & 1 & 0,75 & 0,75 & 0,75 & 0,75 & 0,75 & 0,75 & 1,5 \\
\hline $\begin{array}{c}\text { Phusion Hot } \\
\text { Start II } \\
(2 \mathrm{U} / \mu \mathrm{L})\end{array}$ & 0,5 & 0,5 & 0,5 & 0,25 & 0,25 & 0,25 & 0,25 & 0,25 & 0,5 & 0,25 \\
\hline Total & 50 & 50 & 50 & 25 & 25 & 25 & 25 & 25 & 25 & 25 \\
\hline
\end{tabular}

Fonte: Autoria própria.

Em seguida a amostra foi purificada utilizando o kit de extração em gel (GeneJET Gel Extraction Kit) da Thermo Ficher Scientific.

\subsubsection{Digestão e Ligação}

Devido à baixa concentração de cDNA obtido na amplificação, as reações de digestão do inserto e do vetor foram feitas em conjunto e sem purificação antes da reação de ligação. Como as enzimas de restrição utilizadas, NcoI e XhoI, possuem $100 \%$ de atividade no tampão 3 e que ambas possuem a mesma temperatura de inativação, foi possível realizar a reação de digestão seguida da inativação das enzimas de restrição. 
A reação foi alcançada partindo-se de uma proporção molar de 10:1 (inserto:vetor), as concentrações de vetor, inserto, enzimas de restrição e tampão utilizados na reação estão indicadas na Tabela 4.

Tabela 4 - Volumes e concentração dos reagentes utilizados na reação de digestão do vetor e do inserto.

\begin{tabular}{|c|c|c|}
\hline AMOSTRA & $\begin{array}{c}\text { VOLUME } \\
\text { UTILIZADO }\end{array}$ & $\begin{array}{c}\text { CONCENTRAÇÃO } \\
\text { DA AMOSTRA } \\
\text { ADICIONADA }\end{array}$ \\
\hline pET28a & $4,3 \mu \mathrm{L}$ & $42,35 \mathrm{ng} / \mu \mathrm{L}$ \\
\hline cDNA (CDK11) & $30 \mu \mathrm{L}$ & $10,51 \mathrm{ng} / \mu \mathrm{L}$ \\
\hline NcoI & $2,5 \mu \mathrm{L}$ & $10000 \mathrm{U} / \mathrm{mL}$ \\
\hline XhoI & $1,25 \mu \mathrm{L}$ & $20000 \mathrm{U} / \mathrm{mL}$ \\
\hline $\begin{array}{c}\text { Tampão } 3 \\
\text { (NEBuffer) } 10 x\end{array}$ & $5 \mu \mathrm{L}$ & - \\
\hline $\mathrm{H}_{2} \mathrm{O}$ & $7 \mu \mathrm{L}$ & - \\
\hline Volume total & $50 \mu \mathrm{L}$ & - \\
\hline
\end{tabular}

A reação foi mantida por 1 hora e 30 minutos a $37^{\circ} \mathrm{C}$, em seguida foi feita a inativação das enzimas a $65{ }^{\circ} \mathrm{C}$ por 20 minutos. Após a digestão, todo o volume da reação $(50 \mu \mathrm{L})$ foi submetido ao procedimento de ligação conforme descrito na tabela 5.

Tabela 5 - Reação de ligação entre o vetor e o inserto.

\begin{tabular}{|c|c|c|}
\hline AMOSTRA & $\begin{array}{c}\text { VOLUME } \\
\text { UTILIZADO }\end{array}$ & $\begin{array}{c}\text { CONCENTRAÇÃO } \\
\text { DA AMOSTRA } \\
\text { ADICIONADA }\end{array}$ \\
\hline Produto da digestão & $50 \mu \mathrm{L}$ & - \\
\hline T4 DNA ligase & $3,5 \mu \mathrm{L}$ & $1 \mathrm{U} / \mu \mathrm{L}$ \\
\hline Tampão de ligação da DNA T4 ligase 10x & $7 \mu \mathrm{L}$ & - \\
\hline ATP & $7 \mu \mathrm{L}$ & $10 \mathrm{mM}$ \\
\hline $\mathrm{H}_{2} \mathrm{O}$ & $2,5 \mu \mathrm{L}$ & - \\
\hline
\end{tabular}

O procedimento da ligação foi feito overnight a $16{ }^{\circ} \mathrm{C}$ e o produto obtido foi estocado a $-20^{\circ} \mathrm{C}$.

\subsubsection{Transformação do produto de ligação em células DH5 $\alpha$}

Foram adicionados $20 \mu \mathrm{L}$ do produto de ligação a $100 \mu \mathrm{L}$ da amostra de células competentes DH5 $\alpha$. As células competentes foram preparadas pelo método do cloreto de cálcio, no qual essas amostras são congeladas em uma suspensão contendo 
$\mathrm{CaCl}_{2}$ 0,1 mol / L e glicerol $10 \%$ e mantidas a $-80{ }^{\circ} \mathrm{C}$ até a sua utilização. A mistura foi mantida no gelo por 30 minutos, seguida de choque térmico de $42{ }^{\circ} \mathrm{C}$ durante 2 minutos e transferida para o gelo por mais 3 minutos (o choque térmico facilita a passagem do DNA exógeno através da parede celular e da membrana plasmática da célula).

Após o choque, foram adicionados as amostras $500 \mu \mathrm{L}$ de meio Luria-Bertani (LB) líquido, composto por $10 \mathrm{~g} / \mathrm{L}$ de triptona, $5 \mathrm{~g} / \mathrm{L}$ de extrato de levedura e $10 \mathrm{~g} / \mathrm{L}$ de $\mathrm{NaCl}$ em água destilada. A mistura foi incubada em um shaker a $37^{\circ} \mathrm{C}$ e $200 \mathrm{rpm}$ durante 1 hora.

As culturas crescidas no shaker foram então aplicadas em placas de Petri contendo $20 \mathrm{~mL}$ de meio sólido LB-ágar que contêm $30 \mu \mathrm{g} / \mathrm{mL}$ do antibiótico canamicina (confere resistência as células que contenham o vetor pET28a). As placas foram incubadas em estufa a $37^{\circ} \mathrm{C}$ overnight.

\subsubsection{PCR de colônia}

Da placa obtida anteriormente selecionou-se 6 colônias, e cada colônia foi solubilizada em $15 \mu \mathrm{L}$ de água Milli Q autoclavada e incubada por $95{ }^{\circ} \mathrm{C}$ durante 20 minutos. Em seguida, para o conteúdo de cada colônia obtida foram adicionados os reagentes, conforme indicado na tabela 6 .

Tabela 6 - Reação de PCR de colônia utilizando os primers da CDK11 $\Delta$.

\begin{tabular}{|c|c|}
\hline REAGENTE & VOLUME \\
\hline $\mathrm{H}_{2} \mathrm{O}$ & $4 \mu \mathrm{L}$ \\
\hline Taq Buffer $+\left(\mathrm{NH}_{4}\right)_{2} \mathrm{SO}_{4} \cdot \mathrm{MgCl}_{2}(10 x)$ & $1 \mu \mathrm{L}$ \\
\hline dNTPs $(10 \mathrm{mM})$ & $0,4 \mu \mathrm{L}$ \\
\hline Primer Fw da CDK11 $\Delta$ (10 uM) & $0,4 \mu \mathrm{L}$ \\
\hline Primer Rv da CDK11 $\Delta$ (10 uM) & $0,4 \mu \mathrm{L}$ \\
\hline Template DNA & $3 \mu \mathrm{L}$ \\
\hline $\mathrm{MgCl}_{2}(25 \mathrm{mM})$ & $0,7 \mu \mathrm{L}$ \\
\hline Taq Polimerase & $0,1 \mu \mathrm{L}$ \\
\hline
\end{tabular}

Fonte: Autoria própria.

Os produtos de PCR foram aplicados no gel de agarose $0,8 \%$, sendo possível identificar, pela análise do gel, a colônia que continha o DNA recombinante. Essa colônia foi submetida a um pré-inóculo em $5 \mathrm{~mL}$ de meio LB. Desses $5 \mathrm{~mL}$ de pré-inóculo crescidos overnight, $700 \mu \mathrm{L}$ foram estocados a $-80{ }^{\circ} \mathrm{C}$ com $300 \mu \mathrm{L}$ de glicerol $50 \%$ previamente autoclavado. $\mathrm{O}$ volume de $4,3 \mathrm{~mL}$ do pré-inóculo restantes 
foram purificados utilizando o kit miniprep (GeneJET Plasmid Miniprep Kit) da Thermo Ficher Scientific.

\subsubsection{Sequenciamento do DNA}

Uma amostra do plasmídeo recombinante pET28a::CDK11 que mostrou resultado positivo no teste de PCR de colônia foi submetido ao sequenciamento do DNA, o qual foi realizado no Laboratório de Biologia Molecular do Grupo de Cristalografia do Instituto de Física de São Carlos - IFSC/USP. O sequenciamento foi feito no equipamento 3130 Genetic Analyzer (Applied Biosystems). Ele emprega o método de Sanger automatizado, em que os terminadores de cadeia (ddNTPs) contêm marcadores fluorescentes que permite a identificação da sequência analisada.

Os resultados obtidos foram alinhados com a sequência esperada, a fim de avaliar a integridade do recombinante.

\subsection{Expressão, reenovelamento e purificação da CDK11 $\Delta$ a partir do recombinante $\mathrm{pET} 28 \mathrm{a}: \mathrm{CDK} 11 \Delta$}

Vários protocolos foram testados para determinação do protocolo final para a expressão e purificação da CDK11.

Inicialmente, na tentativa de expressar a isoforma 1A completa da CDK11, PAPARIDIS (2015) testou diversos protocolos incluindo diversas cepas de expressão, mas a proteína não foi expressa nem na fração solúvel nem na insolúvel, experimentos conduzidos pelo pesquisador levou a conclusão que a CDK11p110 possui uma sequência polipeptídica muito incomum em seu $\mathrm{N}$-terminal para ser expressa em sistema procarioto, pois possui um segmento de 33 resíduos dos quais 28 são glutamatos e dois segmentos contínuos de 13 resíduos de glutamato o que gera uma densidade de cargas negativa muito alta na região $\mathrm{N}$-terminal prejudicando a síntese proteica em sistema heterólogo. 
Diante disso a região N-terminal foi removida e finalmente foi possível expressar a proteína, mas na fração insolúvel, mesmo tendo testadas diversas condições de expressão.

Nesse cenário, no atual estudo, análises de bioinformática foram realizadas a fim de adquirir uma forma ainda mais encurtada, retirando-se também parte do C-terminal, a fim de deixar apenas a sequência da proteína referente ao domínio quinase da CDK11 sem a presença de códons raros e sem estruturas desordenadas. A proteína final, após essas modificações foi denominada de CDK11 $\Delta$. Essa estratégia foi escolhida por já ter sido utilizada para outras quinases maiores, tais como a CDK13 (GREIFENBERG et al., 2016), pois facilitam sua expressão em sistema heterólogo e sua cristalização.

Inicialmente foram feitos testes de indução para a obtenção da proteína solúvel, utilizando como referência o protocolo de LEOPOLDINO et al. (2006), que obteve a CDK9 expressa na fração solúvel. No entanto, com esse protocolo e com variações do mesmo, não foi possível obter a $\mathrm{CDK} 11 \Delta$ em sua forma solúvel.

A utilização do plasmídeo recombinante pG-KJE8 que expressa chaperona, baseando-se nos estudos de GRIGOROUDIS et al. (2015) e a utilização de meio autoindutor (STUDIER, 2005) também foram testadas sem sucesso.

Baseando-se então no protocolo de PAPARIDIS (2015) que conseguiu superexpressar na fração insolúvel outra forma encurtada da CDK11, mas não testou seu reenovelamento com dodecil sulfato de sódio (SDS), e no protocolo de reenovelamento de HE e OHNISHI (2017), diferentes condições foram testadas para a CDK11 $\Delta$ (Tabela 7). 
Tabela 7 - Testes de expressão utilizando diferentes condições. Em vermelho são mostradas as melhores condições para a superexpressão, lise e reenovelamento da $\mathrm{CDK} 11 \Delta$.

\begin{tabular}{|c|c|c|c|c|c|}
\hline Expressão & Inóculo & Tempos & IPTG & Temperatura & $\begin{array}{l}\text { Outras } \\
\text { modificações }\end{array}$ \\
\hline Exp. 1 & $\begin{array}{l}200 \mathrm{~mL} \\
\text { meio LB }\end{array}$ & $\begin{array}{l}0 \text { horas } \\
3 \text { horas } \\
7 \text { horas }\end{array}$ & $1 \mathrm{mM}$ & $37^{\circ} \mathrm{C}$ & - \\
\hline Exp. 2 & $\begin{array}{l}200 \mathrm{~mL} \\
\text { meio LB }\end{array}$ & $\begin{array}{l}0 \text { horas } \\
3 \text { horas } \\
\text { sonicado }\end{array}$ & $1 \mathrm{mM}$ & $37^{\circ} \mathrm{C}$ & - \\
\hline Exp. 3 & $\begin{array}{l}200 \mathrm{~mL} \\
\text { meio LB }\end{array}$ & $\begin{array}{c}0 \text { horas } \\
3 \text { horas } \\
\text { sonicado }\end{array}$ & $1 \mathrm{mM}$ & $37^{\circ} \mathrm{C}$ & $\begin{array}{c}\text { SDS sem e } \\
\underline{\text { com sonicação }}\end{array}$ \\
\hline Exp. 4 & $\begin{array}{c}1 \mathrm{~L} \\
\underline{\text { meio }} \\
\underline{\text { otimizado }}\end{array}$ & $\begin{array}{l}0 \text { horas } \\
3 \text { horas } \\
\text { sonicado }\end{array}$ & $1 \mathrm{mM}$ & $37^{\circ} \mathrm{C}$ & $\underline{\mathrm{SDS}}$ e $\mathrm{KCl}$ \\
\hline Exp. 5 & $\begin{array}{c}1 \mathrm{~L} \\
\underline{\text { meio }} \\
\underline{\text { otimizado }}\end{array}$ & $\begin{array}{c}0 \text { horas } \\
3 \text { horas } \\
\text { sonicado }\end{array}$ & $1 \mathrm{mM}$ & $37^{\circ} \mathrm{C}$ & 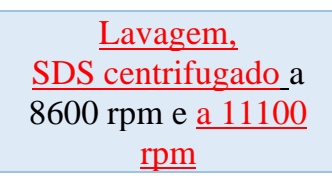 \\
\hline Exp. 6 & $\begin{array}{c}1 \mathrm{~L} \\
\underline{\text { meio }} \\
\underline{\text { otimizado }}\end{array}$ & $\begin{array}{l}0 \text { horas } \\
\underline{5 \text { horas }} \\
\underline{\text { sonicado }} \\
\end{array}$ & $1 \mathrm{mM}$ & $37^{\circ} \mathrm{C}$ & $\begin{array}{c}\text { Mais imidazol e } \mathrm{NaCl} \\
\text { no tampão de } \\
\text { resuspensão }\end{array}$ \\
\hline Exp. 7 & $\begin{array}{c}1 \mathrm{~L} \\
\underline{\text { meio }} \\
\underline{\text { otimizado }}\end{array}$ & $\begin{array}{r}0 \text { horas } \\
\underline{5 \text { horas }} \\
\underline{\text { sonicado }}\end{array}$ & $\underline{\underline{0,1}}$ & $37^{\circ} \mathrm{C}$ & $\begin{array}{l}\text { Coluna de afinidade } \\
\text { na purificação }\end{array}$ \\
\hline Exp. 8 & $\begin{array}{c}1 \mathrm{~L} \\
\underline{\text { meio }} \\
\underline{\text { otimizado }}\end{array}$ & $\begin{array}{r}0 \text { horas } \\
\underline{5 \text { horas }} \\
\underline{\text { sonicado }} \\
\end{array}$ & $\underline{\frac{0,1}{\mathrm{mM}}}$ & $37^{\circ} \mathrm{C}$ & $\begin{array}{l}\text { Coluna de afinidade e } \\
\text { de exclusão molecular } \\
\text { na purificação }\end{array}$ \\
\hline Exp. 9 & $\begin{array}{c}1 \mathrm{~L} \\
\underline{\text { meio }} \\
\underline{\text { otimizado }}\end{array}$ & $\begin{array}{r}0 \text { horas } \\
5 \text { horas } \\
\underline{\text { sonicado }} \\
\end{array}$ & $\underline{0,1}$ & $37^{\circ} \mathrm{C}$ & $\begin{array}{l}\text { Três lavagens do } \\
\text { pellet ao invés de uma }\end{array}$ \\
\hline Exp. 10 & $\begin{array}{c}1 \mathrm{~L} \\
\underline{\text { meio }} \\
\underline{\text { otimizado }}\end{array}$ & $\begin{array}{r}0 \text { horas } \\
5 \text { horas } \\
\underline{\text { sonicado }} \\
\end{array}$ & $\underline{\underline{0,1}}$ & $37^{\circ} \mathrm{C}$ & $\begin{array}{c}\text { Diminuiçãa do tempo } \\
\text { de precipitação do } \\
\text { SDS para } 20 \text { minutos } \\
\text { a } 4 * \mathrm{C}\end{array}$ \\
\hline Exp. 11 & $\begin{array}{c}1 \mathrm{~L} \\
\underline{\text { meio }} \\
\underline{\text { otimizado }}\end{array}$ & $\begin{array}{r}0 \text { horas } \\
5 \text { horas } \\
\underline{\text { sonicado }} \\
\end{array}$ & $\underline{\underline{0,1}}$ & $37^{\circ} \mathrm{C}$ & $\begin{array}{c}\text { Utilização de } \\
10 \text { mM de } \\
\beta \text {-mercaptoetanol nos } \\
\text { tampões de } \\
\text { ressuspensão e diálise }\end{array}$ \\
\hline
\end{tabular}

Fonte: Autoria própria. 
Por fim, as condições finais escolhidas para indução, lise, reenovelamento e purificação escolhidas estão detalhadas nos tópicos a seguir.

\subsubsection{Indução}

Células da linhagem BL21(DE3) foram transformadas com o plasmídeo recombinante pET28a::CDK11 , e crescidas em $5 \mathrm{~mL}$ de meio $\mathrm{LB}$ a $37^{\circ} \mathrm{C}$, overnight.

O pré-inóculo foi então transferido para um erlenmeyer contendo $1 \mathrm{~L}$ de meio LB líquido otimizado (20 g de triptona, $10 \mathrm{~g}$ de extrato de levedura, $5 \mathrm{~g}$ de $\mathrm{NaCl}, 4 \mathrm{~g}$ de $\mathrm{KCl}$, $3 \mathrm{~g}$ de $\mathrm{MgCl}_{2} \cdot 6 \mathrm{H}_{2} \mathrm{O}, 6,057 \mathrm{~g}$ de Tris Base e $10 \mathrm{~mL}$ de glicerol), e mantido a $250 \mathrm{rpm}$, a $37^{\circ} \mathrm{C}$. O crescimento da cultura foi monitorado a partir da leitura da densidade ótica (DO) a $600 \mathrm{~nm}$. Quando a DO atingiu um valor entre 0,5 e 0,6 unidades de absorbância, foi adicionado 0,1 $\mathrm{mM}$ de IPTG (isopropil B-D-1-tiogalactopiranosídeo) para induzir a expressão.

Após 5 horas de indução, todo o meio foi centrifugado a $4{ }^{\circ} \mathrm{C}$ a $8600 \mathrm{rpm}$ por 40 minutos, e os sedimentos bacterianos foram armazenados a $-20{ }^{\circ} \mathrm{C}$ até a sua utilização.

\subsubsection{Lise das células}

Para cada grama de sedimento bacteriano foram utilizados $5 \mathrm{~mL}$ do tampão de lise (15 mM de Tris- $\mathrm{HCl}, 100 \mathrm{mM}$ de $\mathrm{NaCl}, 10 \mathrm{mM}$ de $\mathrm{MgCl}_{2} \mathrm{H}_{2} \mathrm{O}, 10 \%$ de glicerol e pH 7,4). Após ressuspensão no tampão, as amostras coletadas receberam PMSF (fluoreto de fenilmetilsulfonil), DNase e lisozima (para uma concentração final de $1 \mathrm{mM}, 0,1 \mathrm{U}$ / $\mathrm{mL}$ e $0,1 \mathrm{mg} / \mathrm{mL}$, respectivamente), e foram incubadas no gelo por 30 minutos.

Em seguida, foram sonicadas no sonicador Sonic Model 500 (Fisher Scientific), em 10 pulsos de 30 segundos com intervalos de 59,9 segundos para dissipação do calor numa amplitude de 20\%. A sonicação foi realizada no Laboratório de Biologia Molecular do grupo NEQUIMED, sob coordenação do Prof. Dr. Carlos Alberto Montanari.

Ao final, as amostras foram centrifugadas a $4{ }^{\circ} \mathrm{C}$ e $14000 \mathrm{rpm}$ por 30 minutos para separar a fração insolúvel (pellet) do sobrenadante. As amostras foram nomeadas com os respectivos tempos de indução seguido da letra " $p$ " para o pellet e "s" para o sobrenadante. Por exemplo, o " $5 \mathrm{~s}$ " representa a amostra do sobrenadante após 5 horas de indução. 
O pellet do tempo final foi também lavado com $10 \mathrm{~mL}$ de tampão de lavagem (20 mM de Tris-HCl) e centrifugado a $4{ }^{\circ} \mathrm{C}$ a $11100 \mathrm{rpm}$ por 10 minutos. Esse procedimento de lavagem foi feito 3 vezes e os sobrenadantes das lavagens foram nomeados de "L1, L2 e L3", referentes a lavagens 1, 2 e 3, respectivamente.

\subsubsection{Reenovelamento com SDS}

O pellet lavado, foi ressuspenso em $7 \mathrm{~mL}$ de tampão de ressuspensão $(50 \mathrm{mM}$ de Tris- $\mathrm{HCl}, 300 \mathrm{mM}$ de $\mathrm{NaCl}, 5 \mathrm{mM}$ de imidazol, $2 \%$ de SDS, $10 \mathrm{mM}$ de $\beta$-mercaptoetanol e pH 7,4) e após ressuspensão as amostras foram agitadas overnight, e em seguida foram sonicadas em 5 pulsos de 30 segundos com intervalos de 59,9 segundos para dissipação do calor, numa amplitude de $20 \%$.

Após sonicação, a amostra foi armazenada a $4{ }^{\circ} \mathrm{C}$ por 20 minutos e em seguida centrifugada a $4{ }^{\circ} \mathrm{C}$ a $11100 \mathrm{rpm}$, por 10 minutos. O sobrenadante recebeu o nome de SDSs e o pellet de SDSp.

\subsubsection{Purificação por cromatografia de afinidade}

A CDK11 $\Delta$ possui uma cauda de poli-histidina (His6) N-terminal, a qual permite a sua purificação por cromatografia de afinidade utilizando a resina IMAC (immobilized metal ion affinity chromatography) (GE HealthCare).

Nesse procedimento, a coluna foi pré-equilibrada com o tampão de ligação (50 mM de Tris-HCl, $300 \mathrm{mM}$ de $\mathrm{NaCl}, 5 \mathrm{mM}$ de imidazol, $10 \%$ de glicerol, $10 \mathrm{mM}$ de $\beta$-mercaptoetanol e $\mathrm{pH} 7,4$ ) e então a fração do sobrenadante (nomeada de SDSs) foi aplicada na coluna que contêm a resina Profinity ${ }^{\mathrm{TM}}$ (BioRad) carregada com os cátions $\mathrm{Ni}^{2+}$. Em seguida foi feita a eluição utilizando um gradiente de imidazol.

O tampão de eluição possui a mesma composição do tampão de ligação, com a adição de $500 \mathrm{mM}$ de imidazol, ao invés de $5 \mathrm{mM}$. O volume utilizado no gradiente foi de $94 \mathrm{~mL}$ e o fluxo utilizado de $1 \mathrm{~mL} / \mathrm{min}$. As frações de $1 \mathrm{~mL}$ obtidas foram analisadas em gel de poliacrilamida a $15 \%$.

Para facilitar o entendimento dos procedimentos descritos desde a indução até a purificação da proteína de interesse, um diagrama esquemático pode ser observado na Figura 23. 
Figura 23. Diagrama esquemático dos processos de indução, lise, reenovelamento e purificação da CDK11 $1 \Delta$

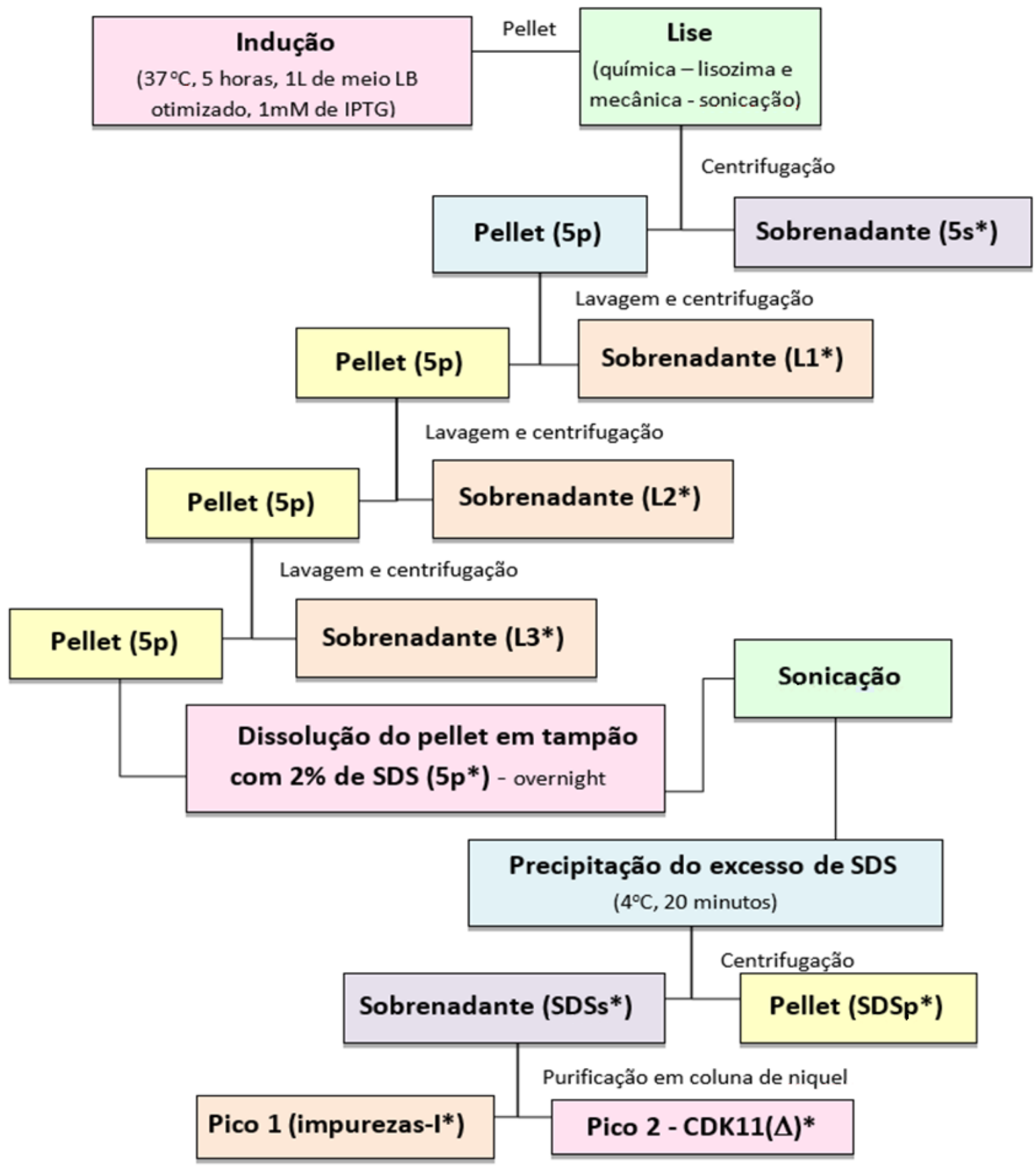

*Amostras analisadas em SDS-PAGE

Fonte: Autoria própria. 


\subsubsection{Eletroforese em gel de poliacrilamida (SDS-PAGE)}

O padrão proteico foi avaliado pela análise do gel de poliacrilamida desnaturante a 15\% (SDS-PAGE). A eletroforese foi feita para avaliar o conteúdo de proteínas solúveis (presentes no sobrenadante-s) e insolúveis (presentes no pellet-p) obtidas nos testes de indução, lise, reenovelamento e purificação (as frações analisadas no gel estão destacadas com asterisco na Figura 23).

Como padrão de referência, uma raia do gel foi reservada para aplicação do marcador de massa molecular contendo bandas entre 14,4 e 116,0 kDa (Unstained Protein Molecular Weight Marker) (Fermentas). A cada amostra foi adicionado tampão de amostra não redutor na proporção de 1:1 (v/v), e aquecidas durante 5 minutos a $95{ }^{\circ} \mathrm{C}$, imediatamente antes da aplicação no gel. A eletroforese foi iniciada utilizando uma voltagem de $90 \mathrm{~V}$ até entrada no gel de empilhamento, e conduzida a $120 \mathrm{~V}$ após entrada no gel de resolução.

Após a eletroforese, os géis foram corados com o corante Coomassie Brilliant Blue $R$ (BioRad) e em seguida foram descorados para análise das bandas obtidas.

\subsubsection{Diálise e determinação da concentração e pureza da proteína obtida}

As frações coletadas de CDK11 $\Delta$ após purificação, foram submetidas a diálise em tampão $20 \mathrm{mM}$ de Tris- $\mathrm{HCl}, 50 \mathrm{mM}$ de $\mathrm{NaCl}, 5 \%$ de glicerol, $10 \mathrm{mM}$ de $\beta$-mercaptoetanol e $\mathrm{pH} 7,4$.

Após a diálise, utilizando o espectrofotômetro DS-11+ (De Novix) a concentração da amostra foi determinada em triplicata.

Para determinação da pureza, a amostra foi submetida a SDS-PAGE $15 \%$ e a análise utilizando o programa ImageJ, que calcula a porcentagem de pureza da amostra contida no gel de poliacrilamida. Para melhor confiabilidade dos resultados, a amostra também foi analisada em gel nativo, utilizando a mesma metodologia da eletroforese em gel de poliacrilamida, mas sem a utilização de SDS (desnaturante) e de $\beta$-mercaptoetanol (redutor), tanto na composição do gel, quanto no tampão de amostra. Além disso, a amostra não foi aquecida. 


\subsection{Caracterização biofísica da CDK11 $\Delta$}

\subsubsection{Espectroscopia de dicroísmo circular}

A espectroscopia de dicroísmo circular (CD) é uma importante técnica de caracterização estrutural de proteínas, pois se baseia na propriedade que uma molécula quiral possui em absorver a luz circularmente polarizada à esquerda e à direita. E como as proteínas são constituídas de resíduos de aminoácidos que possuem carbonos quirais $\left(\mathrm{C}_{\alpha}\right)$, com essa técnica (na região de $180 \mathrm{~nm}$ a $260 \mathrm{~nm}$ ) é possível predizer o percentual de estruturas secundárias características daquela proteína (ATKINS e PAULA, 2011).

A Figura 24 mostra um espectro de CD característicos de cada estrutura secundária.

Figura 24. Espectros associados aos vários tipos de estrutura.

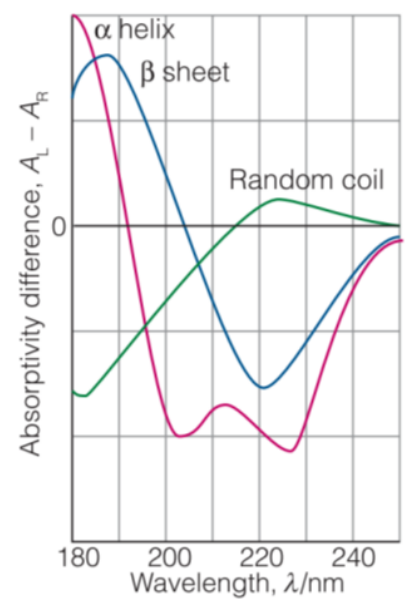

Fonte: ATKINS e PAULA, 2011.

A estimativa do percentual é feita com o auxílio de programas computacionais que utilizam de métodos de deconvolução a partir de um banco de dados de espectros de CD de proteínas cujas estruturas secundárias já são conhecidas (KELLY, JESS e PRICE, 2005). 


\subsubsection{Metodologia dos experimentos de espectroscopia de dicroísmo circular}

Os experimentos de CD foram realizados no espectrômetro Jasco J-815 da Central de Análises Químicas Instrumentais (CAQI) do Instituto de Química de São Carlos (IQSC).

A leitura foi feita de 260 a $185 \mathrm{~nm}$, com D.I.T de $0.5 \mathrm{sec}$, band with de $1.00 \mathrm{~nm}$, data pitch de $0.5 \mathrm{~nm}$, scanning speed de $100 \mathrm{~nm} /$ min e temperatura de $20{ }^{\circ} \mathrm{C}$. Para o branco foram feitas 10 acumulações e para a amostra 20.

A amostra foi preparada pela mistura de $40 \mu \mathrm{L}$ da solução da proteína em tampão $20 \mathrm{mM}$ de Tris- $\mathrm{HCl}, 50 \mathrm{mM}$ de $\mathrm{NaCl}, 5 \%$ de glicerol, $10 \mathrm{mM}$ de $\beta$-mercaptoetanol e pH 7,4 em $760 \mu \mathrm{L}$ de água Milli Q, seguida de centrifugação a $11100 \mathrm{rpm}$, a $4{ }^{\circ} \mathrm{C}$ por 10 minutos. Para a análise utilizou-se $400 \mu \mathrm{L}$ do sobrenadante após centrifugação, e a concentração final da amostra ficou em torno de $0,13 \mathrm{mg} / \mathrm{mL}$, sendo essa averiguada a $280 \mathrm{~nm}$, utilizando espectrofotômetro, ao final de cada análise.

O mesmo procedimento foi realizado sem a proteína, gerando os espectros respectivos do branco correspondentes a cada medida, que foram então subtraídos no tratamento dos dados.

\subsubsection{Determinação do percentual de estrutura secundária da CDK11 1}

Os dados obtidos foram transformados em elipticidade molar utilizando a equação a seguir:

$$
\theta_{m}=\frac{\theta . M W .100}{c . l \cdot n} \quad \text { Equação } 1
$$

Em que $\theta_{\mathrm{m}}$ representa elipticidade ${ }^{2}$ molar em $\frac{\text { grau.cm }^{2}}{d m o l}, \theta$ a elipticidade em graus, MW a massa molecular da proteína em KDa, c a concentração em mg/mL, 1 o caminho óptico da cubeta em cm e n o número de resíduos de aminoácidos da proteína analisada. Em seguida, utilizando o programa CDNN Deconcolution ${ }^{\circledR}$, foi possível determinar o percentual de estruturas secundárias da proteína. 


\subsubsection{Estabilidade da estrutura secundária após armazenamento da CDK11 $14{ }^{\circ} \mathrm{C}$}

Utilizando a mesma metodologia para determinação da estrutura secundária a proteína foi avaliada quando a sua estabilidade por espectroscopia de dicroísmo circular durante um período de 70 dias após armazenamento a $4{ }^{\circ} \mathrm{C}$. A proteína também foi analisada por SDS-PAGE durante esse período.

\subsubsection{Determinação da influência da concentração na estrutura secundária da CDK11 $\Delta$}

O percentual das estruturas secundárias foi determinado para diferentes concentrações da proteína, a fim de avaliar a influência das diferentes concentrações na conformação da proteína. As concentrações utilizadas foram 0,$13 ; 0,097 ; 0,065$ e $0,0325 \mathrm{mg} / \mathrm{mL}$.

\subsubsection{Determinação da influência da temperatura na estabilidade da estrutura secundária da CDK11 $\Delta$}

Monitorando a variação da elipticidade molar em $222 \mathrm{~nm}$ em função do aumento da temperatura, a uma taxa de aquecimento de $1{ }^{\circ} \mathrm{C}$ por minuto, de $20{ }^{\circ} \mathrm{C}$ a $90{ }^{\circ} \mathrm{C}$, foi possível, após ajuste de Boltzmann, utilizando o programa Origin2019, determinar a temperatura em que metade da CDK11 $\Delta$ perde sua estrutura secundária.

Além disso, foi monitorada a estabilidade térmica da estrutura secundária, obtendo a cada $5{ }^{\circ} \mathrm{C}$ um espectro característico da proteína de 190 a $260 \mathrm{~nm}$ a fim de estudar seu comportamento térmico.

\subsubsection{Espectroscopia de emissão de Fluorescência}

Quando uma molécula eletronicamente excitada descarta seu excesso de energia, o elétron que decai para um orbital de menor energia pode gerar um fóton no processo e fazer a amostra brilhar, caso a radiação emitida esteja no espectro visível (ATKINS e PAULA, 2011). Esse tipo de decaimento recebe o nome de decaimento radiativo e um exemplo dele é a fluorescência em que a radiação emitida cessa espontaneamente logo após a radiação excitante se extinguir (ATKINS e PAULA, 2011). 
Na Figura 25 podemos observar um diagrama de Jablonski que ilustra o processo de fluorescência. Nela podemos observar os níveis de energia envolvidos no fenômeno de fluorescência.

Figura 25. Diagrama de Jablonski

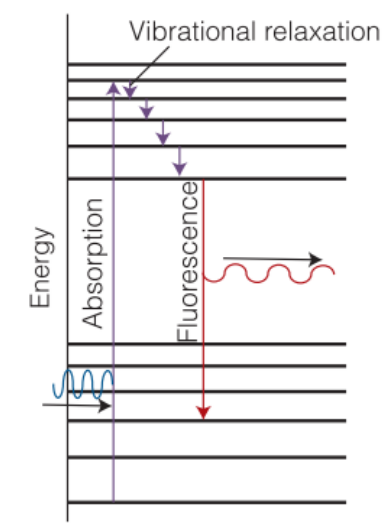

Fonte: ATKINS e PAULA, 2011.

Observe que a absorção inicial leva a molécula para um estado eletrônico excitado. Uma vez excitada a molécula é submetida a colisões com as moléculas circundantes e desce alguns níveis vibracionais, mas não o suficiente para voltar ao estado fundamental. $\mathrm{O}$ estado excitado, no entanto, sobrevive tempo suficiente para gerar um fóton e emitir o restante de energia como radiação.

Desse modo a fluorescência ocorre com uma energia menor (maior comprimento de onda) que a da radiação incidente, pois parte da energia foi descartada nos arredores (ATKINS e PAULA, 2011).

A espectroscopia de emissão de fluorescência pode ser utilizada para estudar proteínas que contenham em sua estrutura aminoácidos fluorescentes (triptofano, tirosina e fenilalanina). Monitorando alterações como a posição do máximo de emissão $\left(\lambda_{\max }\right)$ é possível estudar parâmetros importantes de caracterização estrutural da proteína (LAKOWICZ, 2006).

Como esses aminoácidos são sensíveis ao ambiente externo, proteínas enoveladas em que esses aminoácidos estão interiorizados (longe do solvente) apresentam tipicamente $\lambda_{\max }$ em torno de $330 \mathrm{~nm}$, enquanto proteínas desenoveladas, por estarem com esses aminoácidos expostos ao solvente, apresentam $\lambda_{\max }$ em torno de $350 \mathrm{~nm}$. Sendo assim com essa técnica é possível avaliar o desenovelamento de uma proteína (LAKOWICZ, 2006). 
Outro fenômeno que pode ser estudado por essa técnica é a diminuição da fluorescência quando o fluoróforo de estado excitado é desativado em contato com alguma outra molécula em solução, que é chamado de quencher. Com esse fenômeno é possível estudar a interação de uma proteína com seu ligante, para avaliar se a proteína está ou não interagindo com o composto de interesse (LAKOWICZ, 2006).

\subsubsection{Estudo da estabilidade química na presença de ureia}

Os experimentos de estabilidade na presença da ureia foram realizados no espectrofluorímetro Shimadzu RF-5301 da CAQI-IQSC, utilizando os parâmetros $E X$ wavelength 295nm, EM wavelength range: 305-420nm, Sensivity: High, Scanning speed: medium, Sampling interval: 1.0, slit witdth (nm) EX:3 EM 5, response time (sec): auto.

Para o estudo da estabilidade química foram utilizadas $0,065 \mathrm{mg} / \mathrm{mL}$ da CDK11 $\Delta$, preparada em tampão $20 \mathrm{mM}$ de Tris- $\mathrm{HCl}, 50 \mathrm{mM}$ de $\mathrm{NaCl}, 5 \%$ de glicerol e $\mathrm{pH}$ 7,4 em diferentes concentrações de ureia (0 a $6 \mathrm{M}$, com incrementos de $1 \mathrm{M}$ ), e incubada por 4 horas. Em seguida as amostras foram submetidas a análise por espectroscopia de emissão de fluorescência.

O mesmo procedimento foi realizado sem a proteína, gerando os espectros respectivos do branco correspondentes a cada medida, que foram então subtraídos no tratamento dos dados.

\subsubsection{Estudo da interação da CDK11 $\Delta$ com ATP}

Os experimentos para estudo da interação com ATP foram realizados no espectrofluorímetro Hitachi (F-4500) da CAQI-IQSC, utilizando os parâmetros EX wavelength $280 \mathrm{~nm}$, EM wavelength range: 295-420 nm, Sensivity: High, Scanning speed: medium, Sampling interval: 1.0, slit witdth (nm) EX:3 EM 5, response time (sec): auto.

A CDK11 $\Delta$ na concentração de $0,065 \mathrm{mg} / \mathrm{mL}$ em tampão $20 \mathrm{mM}$ de Tris-HCl, $50 \mathrm{mM}$ de $\mathrm{NaCl}, 5 \%$ de glicerol e pH 7,4 foi titulada com uma solução de ATP 0,5 M e $\mathrm{MgCl}_{2} 1 \mathrm{M}$ dissolvidos no mesmo tampão. 
Após cada adição de $0,5 \mu \mathrm{L}$ de ATP $0,5 \mathrm{M}$ e $0,25 \mu \mathrm{L}$ de $\mathrm{MgCl}_{2} 1 \mathrm{M}$ foi obtido um espectro de emissão de fluorescência, foram feitos no total 10 adições. Considerando a amostra zero (antes da adição) foram obtidos no total 11 espectros.

O mesmo procedimento foi realizado sem a proteína, gerando os espectros respectivos do branco correspondentes a cada medida, que foram então subtraídos no tratamento dos dados.

\subsubsection{Estudo da interação da CDK11 $\Delta$ com roscovitina}

Os experimentos para estudo da interação com Roscovitina foram realizados no espectrofluorímetro Hitachi (F-4500) da CAQI-IQSC, utilizando os parâmetros $E X$ wavelength $280 \mathrm{~nm}$, EM wavelength range: 295-420nm, Sensivity: High, Scanning speed: medium, Sampling interval: 1.0, slit witdth (nm) EX:3 EM 5, response time(sec): auto.

A CDK11 1 na concentração de $0,065 \mathrm{mg} / \mathrm{mL}$ em tampão 20mM de Tris-HCl, $50 \mathrm{mM}$ de $\mathrm{NaCl}, 5 \%$ de glicerol e pH 7,4 foi titulada com uma solução de Roscovitna $10 \mathrm{mM}$ em DMSO.

Após cada adição de $0,5 \mu \mathrm{L}$ da solução de Roscovitina foi obtido um espectro de emissão de fluorescência, foram feitos no total 10 adições. Considerando a amostra zero (antes da adição) foram obtidos no total 11 espectros. O mesmo procedimento foi realizado sem a proteína, gerando os espectros respectivos do branco.

\subsection{Bioinformática}

\subsubsection{Modelagem molecular da CDK11 $\Delta$}

Como a CDK11 não possui estrutura cristalográfica no PDB (Protein Data Bank), optou-se por realizar uma modelagem molecular da CDK11 1 para comparar suas estruturas secundárias com os dados obtidos por dicroísmo circular e para realização da dinâmica visando entender potenciais inibidores para a proteína em estudo.

Em busca do melhor modelo, foram testados 3 programas para a modelagem molecular comparativa, o SwissModel, o I-TASSER e o MODELLER. O SwissModel é um portal interativo, de fácil uso e permitiu modelar rapidamente a CDK11 $1 \Delta$ a partir de variados moldes. O I-TASSER foi classificado como o servidor número 1 para prever 
estruturas proteicas em diversos experimentos. E o MODELLER é capaz de realizar diversas tarefas adicionais, incluindo modelagem usando múltiplos moldes, refinamento de loops e adição de ligantes.

\subsubsection{SWISS-MODEL}

A ferramenta SWISS-MODEL, foi acessada no portal Expasy (https://swissmodel.expasy.org/interactive). A sequência primária da CDK11 destacada em vermelho na Figura 26, foi o ponto de partida na utilização dessa ferramenta, uma vez inserida no site, o programa selecionou os melhores moldes para a proteína estudada.

Figura 26 - Alinhamento de sequências da CDK11 em CDK11 $\Delta$ evidenciando o domínio quinase (Gly419-Phe723) em vermelho.

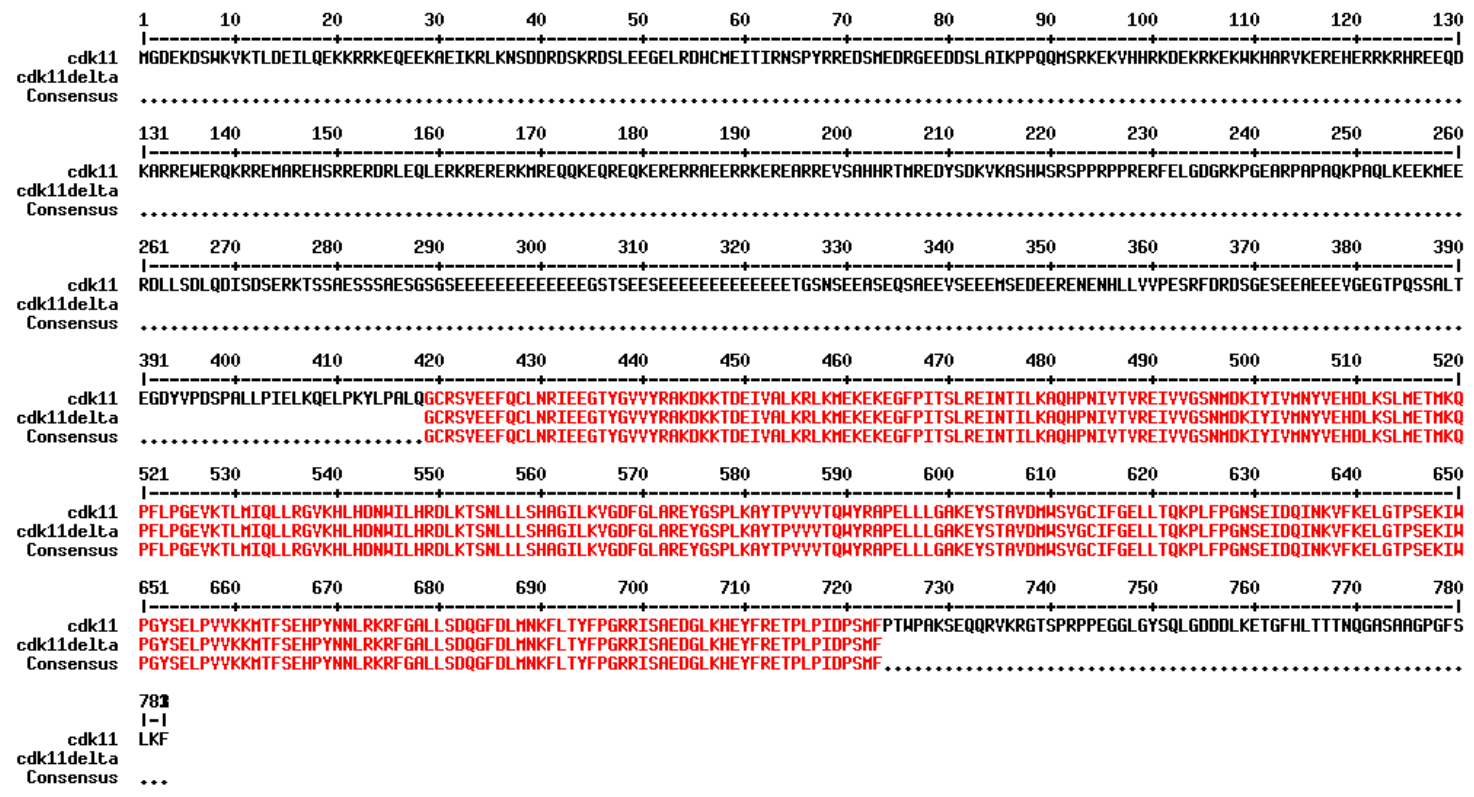

Fonte: Autoria própria.

A pesquisa dos moldes foi executada na biblioteca do SWISS-MODEL (SMTL, última atualização: 2019-04-17, última versão do PDB incluída: 2019-04-12), essa biblioteca utilizou o BLAST e HHBlits.

Além do percentual de identidade sequencial e a cobertura (coverage) entre ambas as sequências, do molde e do alvo, o programa forneceu o método utilizado para a resolução da estrutura do molde, o local em que a biblioteca encontrou a estrutura (BLAST ou HHblits), a resolução da estrutura encontrada e sua descrição. 
Dentre todos esses parâmetros, considerando aqueles de maior identidade sequencial, cobertura e melhor resolução, nós selecionamos os melhores moldes e o programa gerou modelos referentes a todos eles.

Para gerar os modelos, a ferramenta SWISS-MODEL usou o ProMod3 em que os modelos são criados com base no alinhamento do modelo de destino. As coordenadas conservadas entre o destino e o modelo são copiadas do molde para o modelo e inserções e exclusões são remodeladas usando uma biblioteca de fragmentos. Em seguida as cadeias laterais são reconstruídas e, por fim, a geometria do modelo resultante é regularizada usando um campo de força. Caso a modelagem de loops com o ProMod3 falhe, um modelo alternativo é construído utilizando o PROMOD-II.

Para avaliar os modelos gerados o programa disponibilizou parâmetros para avaliação das estruturas geradas, o que permitiu selecionarmos o melhor modelo para a CDK11 $\Delta$, utilizando o SWISS-MODEL.

\subsubsection{I-TASSER}

O servidor I-TASSER (Iterativo Threading Assembly Refinement) foi acessado em: https://zhanglab.ccmb.med.umich.edu/I-TASSER/. Servidor classificado como o número 1 em prever estruturas proteicas para diversos experimentos.

Nesse servidor, a sequência primária da CDK11 (Figura 26) foi inserida e o programa identificou os moldes estruturais, criou modelos para a proteína alvo e os enviou para o e-mail cadastrado.

\subsubsection{MODELLER}

O MODELLER foi obtido no site https://salilab.org/modeller/, para o sistema Windows, versão 9.21. Sua utilização foi sugerida pelo Prof. Dr. Alessandro Silva Nascimento, do Grupo de Biotecnologia Molecular do IFSC/USP, pois o programa é capaz de realizar várias tarefas adicionais (modelagem usando múltiplos moldes, refinamento de loops, adição de ligantes, etc) que permitem refinar o modelo gerado. Para as modelagens feitas no presente estudo utilizou-se a opção de modelagem com múltiplos moldes e posterior adição do ligante $\mathrm{ATP}$, o cofator $\mathrm{Mg}^{2+}$ e as águas necessárias para predizer a estrutura mais provável da CDK11 $\Delta$ na presença do seu ligante natural, o ATP. 
Inicialmente foi realizada uma pesquisa no MODELLER, para obter as estruturas disponíveis no PDB com identidade sequencial mais próxima a CDK11 $\Delta$. Essa mesma busca também foi feita no BLAST. Ambas foram feitas para refinamento da estrutura terciária da proteína modelada, utilizando pelo MODELLER a opção de modelagem com múltiplos modelos.

Após a pesquisa, optou-se por realizar duas modelagens, uma utilizando diferentes CDKs e outra utilizando vários moldes da CDK2 (CDK de maior identidade sequencial com a CDK11 1 ).

Com a finalidade de comparar os modelos gerados traçou-se o perfil de energia dos modelos gerados utilizando o método DOPE (Discrete Optimized Protein Energy).

O método DOPE é uma ferramenta do programa MODELLER que permite avaliar a energia do modelo, geralmente ele é usado para avaliar a qualidade de um modelo de estrutura, seja como um todo ou gerando um perfil de energia resíduo-porresíduo, o que possibilita ao usuário localizar a região do modelo com problemas.

Após cada modelagem, um total de 100 modelos foram construídos, e os 10 melhores foram selecionados de acordo com o método DOPE.

Entre os 100 modelos gerados, avaliou-se os 10 modelos de menor energia para validação pelo SAVES 5.0 (https://servicesn.mbi.ucla.edu/SAVES/) no qual inicialmente foi feita a avaliação no PROCHECK, programa que valida a qualidade estereoquímica de cada resíduo da estrutura proteica, avaliando sua geometria com base no gráfico de Ramachandran (gráfico que avalia os graus de liberdade para cada aminoácido considerando os ângulos diedros $\varphi$ e $\psi$ ).

O modelo escolhido após análise no PROCHECK foi submetido a validação nos demais programas do SAVES: VERIFY, ERRAT, PROVE e WHATCHECK.

\subsubsection{Inserção dos ligantes por modelagem molecular e análise das interações}

\subsubsection{ATP}

Após validação do modelo final da $\operatorname{CDK} 11 \Delta$ foi feita uma pesquisa refinada no banco de dados PDB para encontrar todas as estruturas de CDKs resolvidas com o ligante ATP. 
Dentre as estruturas depositadas, escolheu-se a de código PDB 1qmz, referente a CDK2, estrutura de maior similaridade com a CDK11. Esse modelo foi utilizado para a inserção do ligante ATP ao modelo final anteriormente escolhido utilizando o programa MODELLER.

Em seguida o modelo gerado foi analisado utilizando a ferramenta AutoDockTools 1.5.6 (http://autodock.scripps.edu/resources/adt) com o objetivo de calcular o Ki teórico do ATP com o modelo da CDK11

Com a colaboração do Prof. Dr. Alessandro Silva Nascimento, foi realizada a dinâmica molecular da CDK11 $\Delta$ com o ATP, utilizando o software AMBER a fim de avaliar a energia das principais interações da proteína CDK11 $\Delta$ com seu ligante natural ATP e a flexibilidade da proteína e do ligante.

Inicialmente o sistema foi preparado para uma simulação de equilíbrio com o pacote de programa AMBER (CASE et al., 2005) seguindo os passos descritos em http://nascimento.ifsc.usp.br/wordpress/?page_id=156. O sistema preparado compreendeu a CDK11 $\Delta$, solvente (águas TIP3P), $\mathrm{Mg}^{+2}$ e contra-íons.

Para uma simulação de 200ns foram feitas as etapas conforme descritas em http://nascimento.ifsc.usp.br/wordpress/?page_id=162 (SALOMON-FERRER et al., 2013).

\subsubsection{Roscovitina}

O modelo final da CDK11 $1 \Delta$ utilizado antes da inserção do ATP também foi utilizado para a inserção do ligante Roscovitina, a fim de avaliar seu potencial como inibidor da CDK11.

A estrutura do PDB escolhida como molde para inserção da Roscovitina foi a de código PDB 2A4L, cuja Roscovitina estava complexada com a CDK2 e o programa usado para a inserção do ligante foi o programa MODELLER.

\subsection{Ensaios de cristalização}

Existem diversas estruturas de CDKs depositadas no PDB (https://www.rcsb.org/), entre elas podemos citar, as estruturas das CDKs 1, 2, 4, 5, 6, 7, 8, 9, 12 e 13. Essas estruturas podem conter as CDKs em suas formas monoméricas ou 
com suas parceiras ciclinas, além disso, há várias estruturas depositadas com potenciais inibidores.

O estudo de estruturas cristalográficas permitiu diversas descobertas para entender os mecanismos de interação e participação em vias biológicas. No entanto, há algumas CDKs que ainda não possuem estruturas determinadas, entre essas, podemos citar a CDK11. O estudo estrutural dessa proteína poderá fornecer informações importantes frente a mecanismos biológicos e no estudo de interações com ligantes ou inibidores (WOOD e ENDICOTT, 2018).

No entanto a obtenção de um cristal de uma proteína é um grande desafio, pois enquanto cristais de pequenas moléculas são altamente ordenados e possuem forças de rede firmes o que os torna duros e fáceis de manipular, já os cristais de macromoléculas são mais macios, se quebram mais facilmente e geralmente se desintegram quando desidratados. A desintegração ocorre devido ao alto teor de solvente nos cristais, pois as proteínas são rodeadas por camadas de água que mantêm sua estrutura (MCPHERSONA e GAVIRAB, 2014).

Além disso, para que a cristalização ocorra, é fundamental que o sistema atinja um estado supersaturado para que ocorra a nucleação, em que as moléculas passam de um estado desordenado para um estado ordenado. A medida que o sistema restaura o equilíbrio há o crescimento do cristal e quando a solução torna-se saturada, há a cessação do crescimento cristalino que pode ocorrer também devido a defeitos de crescimento ou envelhecimento da macromolécula e etc. (MCPHERSONA e GAVIRAB, 2014).

Para produzir uma solução supersaturada, as propriedades da solução devem ser modificadas de maneira a reduzir a capacidade do meio de solubilizar a molécula, para isso, uma das técnicas utilizadas é a da gota suspensa (Figura 27).

Figura 27 - Representação da técnica da gota suspensa.

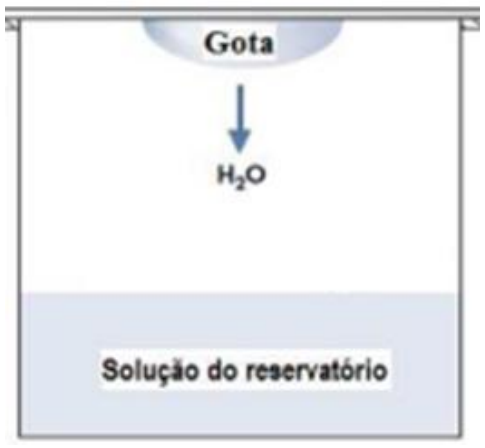

Fonte: DRENTH, 2007. 
Nessa técnica, em uma lamínula, um ou dois microlitros de solução de proteína são misturados com um ou dois microlitros da solução de reservatório contendo precipitantes. Como a mistura na gota é menos concentrada que no reservatório, a água evapora da gota para o reservatório e a concentração de precipitante e de proteína na gota vai aumentando lentamente, podendo ocorrer a formação de cristais (DRENTH, 2007).

Em placas de 24 poços próprias para ensaios de cristalização, utilizando o método da gota suspensa, inicialmente foram feitos testes utilizando polietilenoglicol 4000 (PEG4000) dissolvido em água mili Q, nas concentrações de 10\%, 20\% e 30\%, as concentrações da CDK11 variam de $3 \mathrm{mg} / \mathrm{mL}$ e $7 \mathrm{mg} / \mathrm{mL}$ e as proporções testadas nas gotas foram de 1:1, 1:2 e 2:1 (uL de proteína : uL de solução de PEG4000. Também foram feitos testes nessas mesmas condições com adição de $2 \mathrm{mM}$ de $\mathrm{MgCl}_{2}$ e $2 \mathrm{mM}$ de ATP. A escolha dos reagentes foram feitas após pesquisa das condições que outras CDKs foram cristalizadas.

Em nosso estudo também foram feitos ensaios de cristalização utilizando os kits da Hampton Research: Crystal Screen HR2-110 e Crystal Screen 2 HR2-112. Do kit Crystal Screen HR2-110, testando a proteína nas concentrações de 1,3 mg / mL, 2,6 mg / $\mathrm{mL}, 4,2 \mathrm{mg} / \mathrm{mL}$ e 8,4 mg / mL, e as proporções testadas nas gotas foram de 1:1, 1:2 e 2:1 (uL de proteína : uL de solução). selecionou-se as soluções 1 a 15, 20, 31 a 33, 36 a 41, 43, 44 e 50. Do kit Crystal Screen 2 HR2-112 utilizamos as soluções de 1 a 9. As soluções foram escolhidas analisando-se as soluções nas quais outras CDKs foram obtidas.

\subsection{Estudos dos potenciais inibidores $3 a$, $3 b$ e $3 f$ com a CDK11 $\Delta$}

Em um projeto com parceria da professora Dra. Fernanda Andreia Rosa, da Universidade Estadual de Maringá (UEM) foram avaliados três potenciais compostos inibidores de CDKs, nomeados 3a, 3b e 3f, sintetizados pelo seu grupo de pesquisa. Os compostos sintetizados são análogos ao ATP e portanto, sua interação com as CDKs deve ocorrer de forma sítio-específico.

Os ensaios foram realizados por espectroscopia de emissão de fluorescência no espectrofluorímetro Hitachi (F-4500) da CAQI-IQSC, utilizando os parâmetros EX wavelength 280nm, EM wavelength range: 295-420nm, Sensivity: High, 
Scanning speed: medium, Sampling interval: 1.0, slit witdth (nm) EX:3 EM 5, response time(sec): auto.

A CDK11 $\Delta$ na concentração de 0,065 mg / mL em tampão 20 mM de Tris-HCl, $50 \mathrm{mM}$ de $\mathrm{NaCl}, 5 \%$ de glicerol e pH 7,4 foi titulada com uma solução dos compostos dissolvidos em DMSO (dimetilsulfóxido) para concentrações finais de 0 a $200 \mu \mathrm{M}$.

Adicionalmente, em conjunto com a aluna de doutorado Fernanda Coelho, no Laboratório do professor Dr. Andrei Leitão, foram feitos ensaios utilizando linhagens celulares para a verificação da eficácia dos compostos. Utilizou-se para controle as linhagens de fibroblastos Balb/C3T3 e para os testes, as linhagens celulares MDA-MB231 e MCF-7, que são linhagens de câncer de mama que apresentam superexpressão da proteína CDK11.

O ensaio inicial escolhido foi o de viabilidade celular - MTT, no qual as células eucarióticas foram semeadas em placas de 96 poços com os compostos 3a e $3 \mathrm{f}$ em diferentes concentrações $(10 \mu \mathrm{M}, 50 \mu \mathrm{M}$ e $100 \mu \mathrm{M})$. Utilizou-se como controle negativo somente solução de DMSO 0,5\% (v/v) e como controle positivo, doxorrubicina. O composto $3 b$ será testado futuramente.

As medidas foram realizados após $72 \mathrm{~h}$ de incubação com os compostos e utilizou-se o método MTT (Amresco LLC), em que a incubação com MTT foi feita por 3h e em seguida se adicionou solução solubilizante (SDS 70\% v/v, DMSO 29\% v/v e ácido acético glacial $1 \% \mathrm{v} / \mathrm{v}$ ) a qual foi incubada durante 60 minutos, finalizando com leitura da absorbância em 570 nm utilizando leitor de placas (Biotek Synergy HT). As porcentagens de viabilidade celular foram calculadas utilizando a equação 2 :

$$
\text { Índice de sobrevivência (\%) }=\frac{\mathrm{A}}{\mathrm{CN}} \cdot 100 \% \quad \text { Equação } 2
$$

Em que $\mathrm{A}=$ média das absorbâncias da amostra descontando o branco e $\mathrm{CN}=$ média das absorbâncias do controle negativo, descontando o branco. 


\section{RESULTADOS E DISCUSSÃO}

\subsection{Clonagem da CDK11 $\Delta$ em pET28a}

\subsubsection{Amplificação do cDNA da CDK11 $\Delta$}

Em seu trabalho, Paparidis (2015) relatou que a expressão completa de CDK11p110 em E. coli não era possível nem na fração solúvel nem na insolúvel, mesmo após testar diversos protocolos incluindo diversas cepas de expressão. Ao fim de seus experimentos o pesquisador concluiu que a CDK11p110 completa possui uma sequência polipeptídica muito incomum no seu N-terminal (33 resíduos dos quais 28 são glutamatos e dois segmentos contínuos de 13 resíduos de glutamato, o que gera uma densidade de cargas negativa muito alta), impossibilitando a expressão em sistema procarioto. Isso o levou a testar a expressão de uma forma encurtada da proteína, mas a mesma foi expressa apenas na fração insolúvel e o autor não relatou a tentativa de reenovelamento para essa proteína.

Em nosso estudo realizou-se uma nova análise de bioinformática na sequência de DNA de CDK11 conforme descrito na metodologia. A modificação realizada não interfere no presente estudo, uma vez que o objetivo principal foi obter e caracterizar o domínio da quinase CDK11, responsável por sua atividade catalítica e interação com inibidores. A mesma estratégia foi usada para outras quinases maiores, como a CDK13 (GREIFENBERG et al., 2016).

Após análise de bioinformática, a sequência de cDNA planejada foi adquirida e em seguida foi feita uma amplificação do mesmo. Inicialmente foi realizada uma análise do produto de PCR utilizando um gradiente de temperatura entre 50 e $72{ }^{\circ} \mathrm{C}$ (Figura 28).

Figura 28 - Reação de PCR utilizando um gradiente de temperatura na amplificação do cDNA da CDK11 $\Delta(932 \mathrm{pb})$, em vermelho destaca-se a melhor temperatura escolhida para o anelamento $\left(67,3^{\circ} \mathrm{C}\right)$.

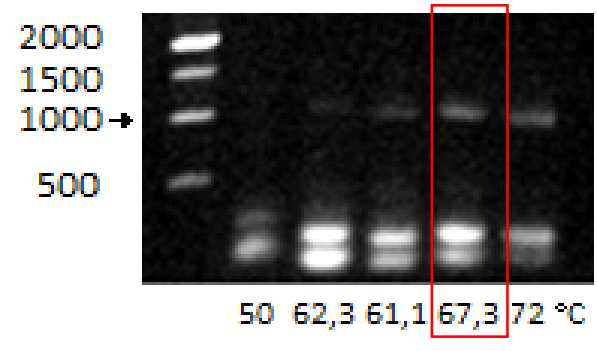

Fonte: Autoria própria. 
O melhor resultado foi para a temperatura de anelamento de $67,3{ }^{\circ} \mathrm{C}$ (em vermelho na Figura 28).

Para melhorar as condições de amplificação foram testadas variações nas condições de PCRs (conforme mostrado na Tabela 3, anteriormente já relatada na metodologia), essas variações levaram em consideração diferentes condições descritas no manual da Phusion Hot Start II (Thermo).

Apesar do perfil ser similar no gel de agarose (resultados mostrados no anexo III) para as diferentes condições testadas, o que obteve maior concentração após purificação foi o PCR3 (Tabela 3, anteriormente já relatada na metodologia), o qual obteve-se 10,51 ng / $\mu \mathrm{L}$. Dessa forma, optou-se pela amostra obtida no PCR3 para digestão e ligação.

\subsubsection{Digestão, ligação e PCR de colônia}

Após digestão, ligação e transformação, foram selecionadas 6 colônias da placa transformada e obteve-se sucesso na amplificação do DNA das colônias 3 e 6, utilizando os primers do próprio inserto (Figura 29).

Figura 29 - Reação de PCR das 6 colônias selecionadas após digestão, ligação e transformação. Em vermelho destaca-se as colônias que continham o recombinante.

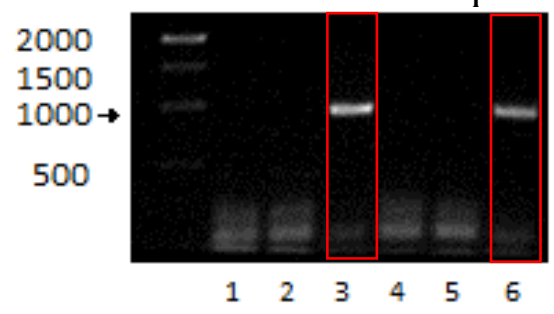

Fonte: Autoria própria.

\subsubsection{Sequenciamento do DNA}

Após alinhamento das sequências utilizando o programa MultiAlin (http://multalin.toulouse.inra.fr/multalin/), a análise do sequenciamento mostrou corresponder com a sequência prevista para a $\operatorname{CDK} 11 \Delta$, visto que a correspondência com o primer direto vai do início até cerca de 1100 pares de bases e com o primer reverso do fim até próximo do nucleotídeo 240 (Figura 30). 
Vale relatar aqui que o sequenciamento tem fidelidade de aproximadamente 600 nucleotídeos iniciais para o primer direto e 600 nucleotídeos finais para o primer reverso, por isso a utilização dos dois primers é fundamental. Também é importante deixar claro que no sequenciamento são utilizados os primers do pET28a, o que leva a leitura de bases além no início e no fim da sequência, as quais pertencem a sequência do vetor. Sendo assim os resultados obtidos estão $100 \%$ de acordo com o esperado (Figura 30).

Figura 30 - Análise do sequenciamento após alinhamento no programa MultiAlin. Em vermelho destacam-se as regiões idênticas entre a CDK11 $\Delta$ e o resultado do sequenciamento utilizando os primers direto e reverso, já em azul as regiões idênticas apenas entre duas sequências. As regiões circuladas em preto indicam os códons de início e de fim.

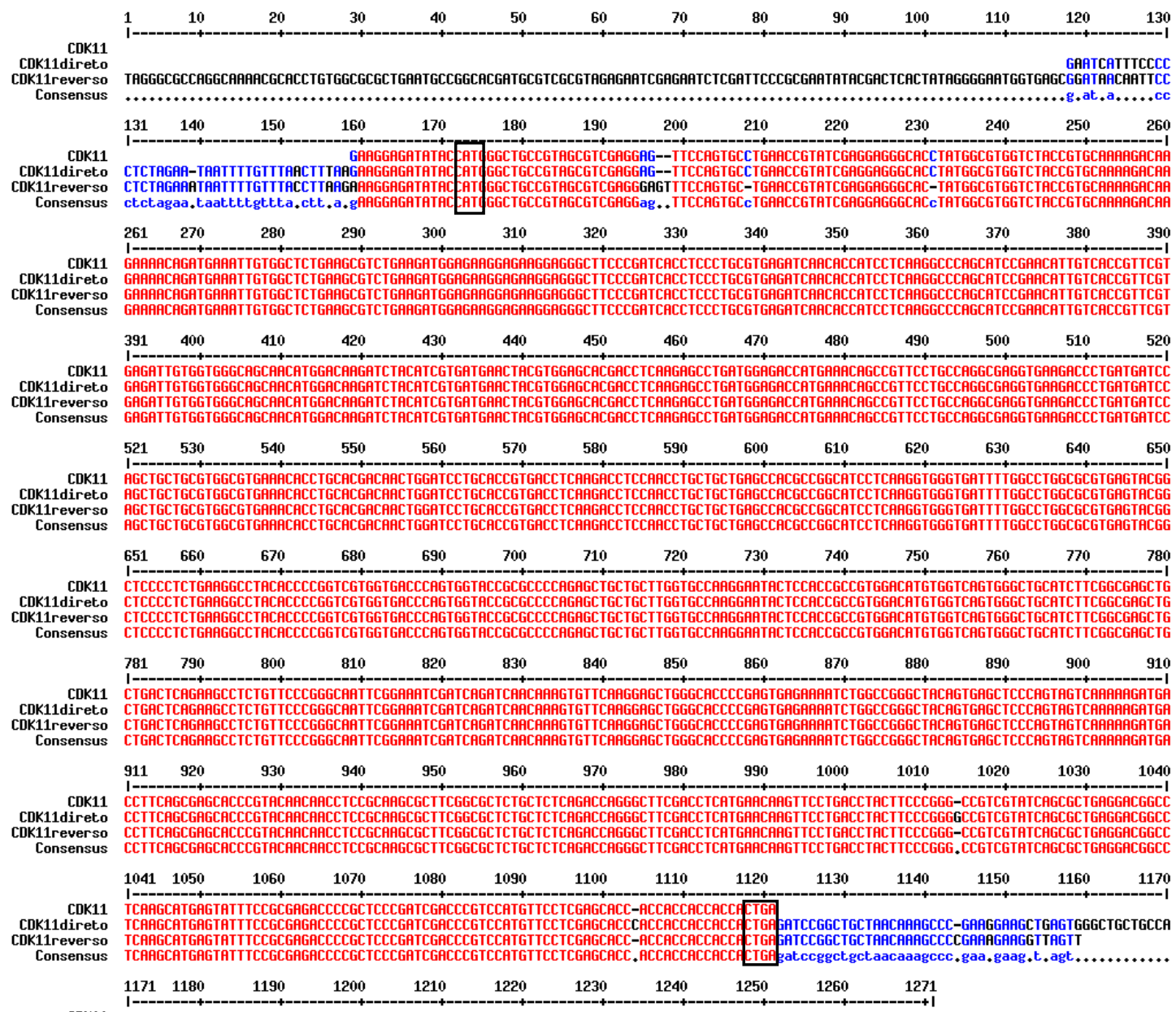

CDK11

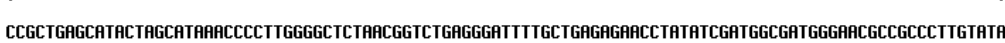
Consensus

Fonte: Autoria própria 


\subsection{Expressão, reenovelamento e purificação da CDK11 $\Delta$ a partir do recombinante $\mathrm{pET} 28 \mathrm{a}: \mathrm{CDK} 11 \Delta$}

Resultados anteriores obtidos por outros membros do nosso grupo de pesquisa mostraram que as proteínas CDK com as quais trabalhamos não se desnaturam com a guanidina. Além disso, experimentos de redobramento usando ureia foram realizados para a CDK9, no entanto a proteína precipitava em ureia $<4 \mathrm{M}$ e por isso foi necessário manter a proteína redobrada em $0,5 \%$ SDS. Além desses problemas, o reenovelamento com ureia gerou baixos rendimentos (PAPARIDIS, 2015).

Nesse contexto, e considerando as inúmeras tentativas de se obter CDKs na fração solúvel terem sido um desafio ainda não superado, após clonagem da CDK11 optou-se por testar o protocolo de LEOPOLDINO et al. (2006), no qual a CDK9 foi expressa na fração solúvel a $30{ }^{\circ} \mathrm{C}$, mas com esse protocolo e com variações do mesmo, não foi possível obter a CDK11 $\Delta$ em sua forma solúvel e nem observar superexpressão da proteína em estudo (as figuras dos géis podem ser observados no anexo IV).

Outras variações, ainda não testadas anteriormente no grupo foram feitas para a CDK11, como a utilização do plasmídeo recombinante pG-KJE8 que expressa chaperona, baseando-se nos estudos de GRIGOROUDIS et al. (2015) e a utilização de meio auto-indutor (STUDIER, 2005), mas não obtivemos sucesso.

Assim, optamos por seguir o protocolo de PAPARIDIS (2015) que conseguiu a superexpressão de uma outra forma encurtada da CDK11 na fração insolúvel, agora utilizando o protocolo de reenovelamento de HE e OHNISHI (2017) para promover o reenovelamento.

Partindo-se das condições obtidas no grupo, várias condições foram testadas para a CDK11s, até otimização de sua expressão e reenovelamento (Tabela 7 da metodologia), os resultados dos géis obtidos podem ser observados no anexo $\mathrm{V}$.

Os resultados obtidos, após otimização dos protocolos, na indução, lise, renovelamento e purificação podem ser observados na Figura 31a. A proteína não é superexpressa na porção solúvel (5s) e também é minimamente perdida nas lavagens (L1, L2 e L3). Já no pellet (5p) pode ser observado uma superexpressão da proteína de interesse, que após protocolo de reenovelamento, passa para a fração solúvel (SDSs). 
Nas amostras obtidas após a cromatografia de afinidade ao níquel (frações I e CDK11 1 ), observa-se que as alíquotas referentes ao primeiro pico (I), contêm muita impureza. Já as amostras referentes ao segundo pico (CDK11 $\Delta)$, contêm alta concentração de CDK11 $1 \Delta$ e poucas impurezas. O gel nativo da CDK11 $\Delta$ purificada pode ser observado na Figura 31b e na Figura 32 pode ser visto o cromatograma obtido na purificação da CDK11 1 .

Figura 31 - (A) Gel de eletroforese com os resultados da indução, lise, reenovelamento e purificação da CDK11 $\Delta$. M - marcador; 5s - sobrenadante após 5horas de indução; L1, L2 e L3 lavagens do pellet feitas após a lise; $5 p$ - pellet após 5 horas de indução e após lavagens; SDSs sobrenadante após reenovelamento; I - impurezas (primeiro pico após aplicação da amostra SDSs na coluna de Níquel) e CDK11 $\Delta$ - proteína de interesse (segundo pico após aplicação da amostra SDSs na coluna de Níquel). A proteína purificada está destacada em vermelho. (B) Gel nativo em que $\mathrm{M}$ refere-se ao marcador e CDK11 $\Delta$ refere-se à proteína de interesse purificada (destacada em vermelho).

(A)

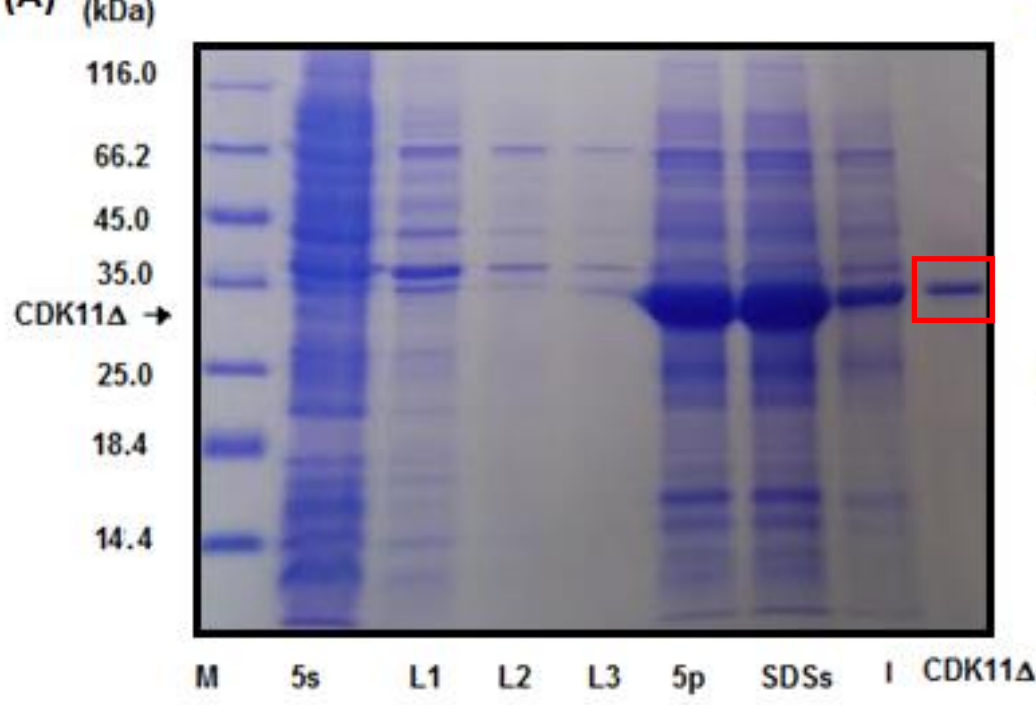

(B)

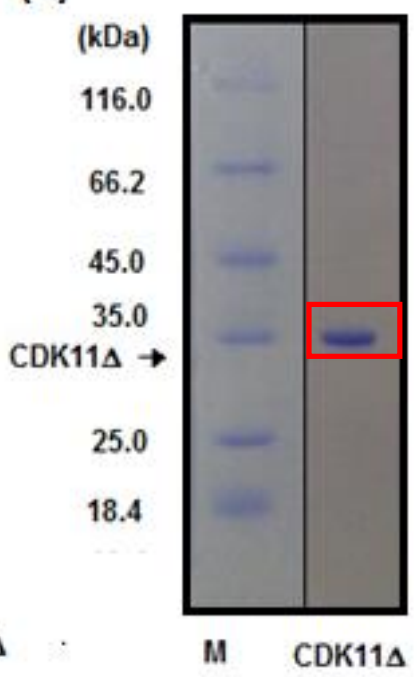

Fonte: Autoria própria. 
Figura 32 - Cromatograma obtido na purificação da CDK11 $($ amostra SDSs), utilizando a resina IMAC (GE HealthCare).

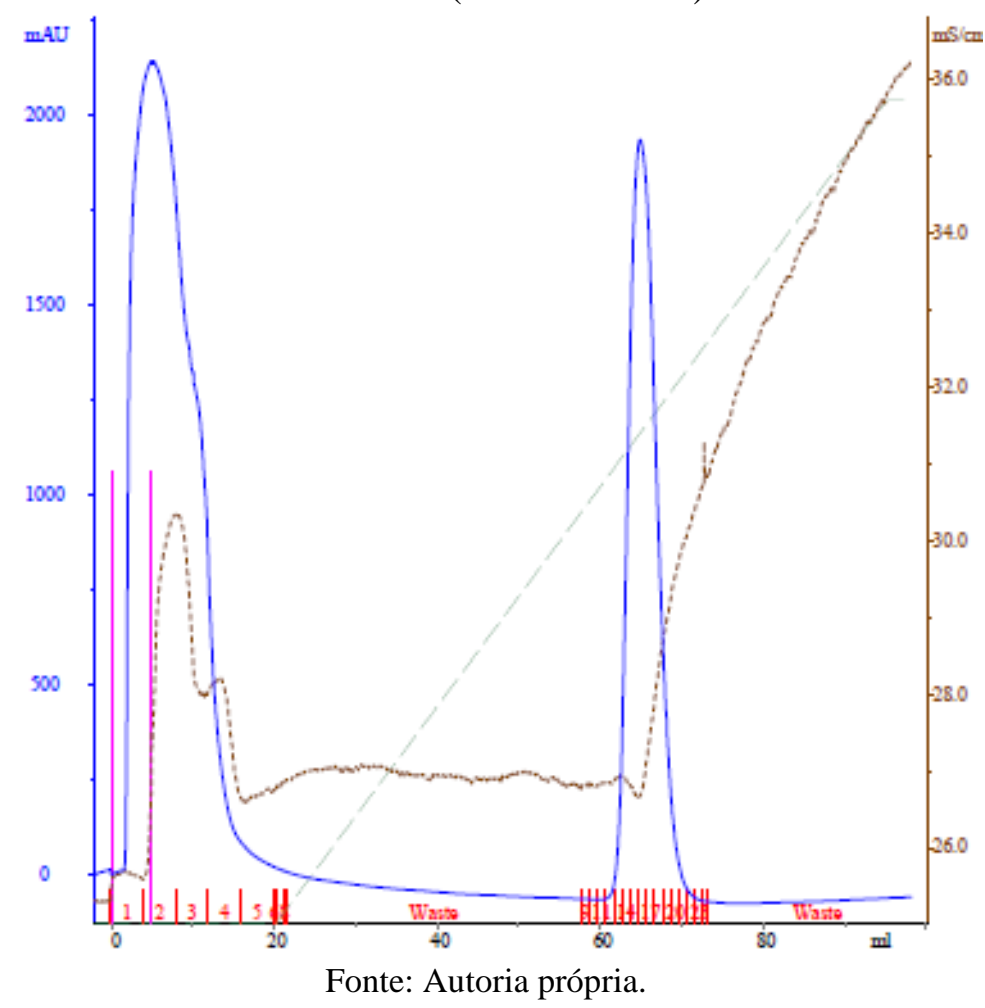

Após os experimentos, conclui-se que a partir de 1L de meio de cultura foi possível obter cerca de $30 \mathrm{mg}$ de proteína heteróloga, com pureza em torno de $97 \%$. Essa proteína foi submetida a caracterização estrutural por dicroísmo circular (CD) e por espectrofluorimetria (realizados em triplicata independente). Também foi possível a realização de ensaios de cristalização.

A obtenção da CDK11 $\Delta$ com pureza e concentração adequada para estudos de caracterização biofísica e para ensaios com ligantes e inibidores, foi possível usando o protocolo adaptado de HE e OHNISHI (2017). Nesse protocolo ao invés de usar um reagente caotrópico como ureia ou cloridrato de guanidina, utilizou-se o detergente SDS (um forte detergente aniônico) que auxilia na solubilização dos corpos de inclusão.

No protocolo original os autores precipitam o SDS a baixa temperatura e o detergente restante é removido após a adição de $\mathrm{KCl}$, que leva a formação de $\mathrm{KDS}$, um sal com menor solubilidade que o SDS (HE e OHNISHI 2017).

Ao aplicar este protocolo para redobrar a $\mathrm{CDK} 11 \Delta$, a adição de $\mathrm{KCl}$ resultou na precipitação da proteína, portanto, adaptou-se o protocolo e removemos esta etapa. O SDS residual foi então eliminado por cromatografia e diálise. Esta modificação torna o protocolo mais simples e fácil e poderá ser utilizada para o reenovelamento de outras 
proteínas que precipitam com $\mathrm{KCl}$. Além disso, outra vantagem da metodologia utilizada é que ela requer apenas uma etapa de purificação.

Além de HE e OHNISHI (2017), outros autores mostraram que o reenovelamento por SDS pode ser realizado com sucesso. Ni e colaboradores obtiveram a proteína preniltransferase NovQ em sua forma ativa com atividade catalítica comparável a outras preniltransferases (NI et al., 2020). Ta e colegas obtiveram a proteína recombinante OvM60-like-1 ativa, após expressão e reenovelamento da proteína obtida em corpos de inclusão de $E$. coli (TA et al., 2020).

Um outro estudo, relatou o redobramento da proteína IFNE recombinante a partir em corpos de inclusão obtidos em E. coli, após solubilização e reenovelamento usando SDS e KCl. Após purificação por cromatografia de afinidade de níquel o recombinante mostrou inibir a sobrevivência celular de câncer de mama, nas linhagens MCF-7 e MDA-MB-231 (ABDEL-FATTAH et al., 2019).

Zhang e colaboradores definiram uma metodologia para preparar partículas semelhantes a vírus (VLPs) que eram expressas como corpos de inclusão usando redobramento com SDS, mesmo após testarem diferentes agentes desnaturantes, como ureia e cloridrato de guanidina, os resultados desejados foram obtidos apenas com SDS e MPD (2-metil-2,4-pentanodiol), usado para dissociar o SDS restante da proteína (ZHANG et al., 2020).

\subsection{Caracterização biofísica da CDK11 $\Delta$}

\subsection{Espectroscopia de dicroísmo circular}

\subsubsection{Determinação do percentual de estrutura secundária da CDK11 1}

No espectro de dicroísmo circular obtido para a CDK11 (Figura 33) pode ser observado que a CDK11 1 mostrou dois mínimos pronunciados próximos a $222 \mathrm{~nm}$ e $208 \mathrm{~nm}$ e um máximo pronunciado próximo de $193 \mathrm{~nm}$. Esses picos são característicos de proteínas contendo majoritariamente hélices $\alpha$ (GREENFIELD, 2006). 
Figura 33 - Espectro de dicroísmo circular para a CDK11 $1 \Delta$ a $0,13 \mathrm{mg} / \mathrm{mL}$ em tampão Tris- $\mathrm{HCl} 20 \mathrm{mM}, \mathrm{NaCl} 50 \mathrm{mM}$, glicerol a $5 \%$ (v/v), $\beta$-mercaptoetanol $10 \mathrm{mM}$ e pH 7,4 diluído 20x.

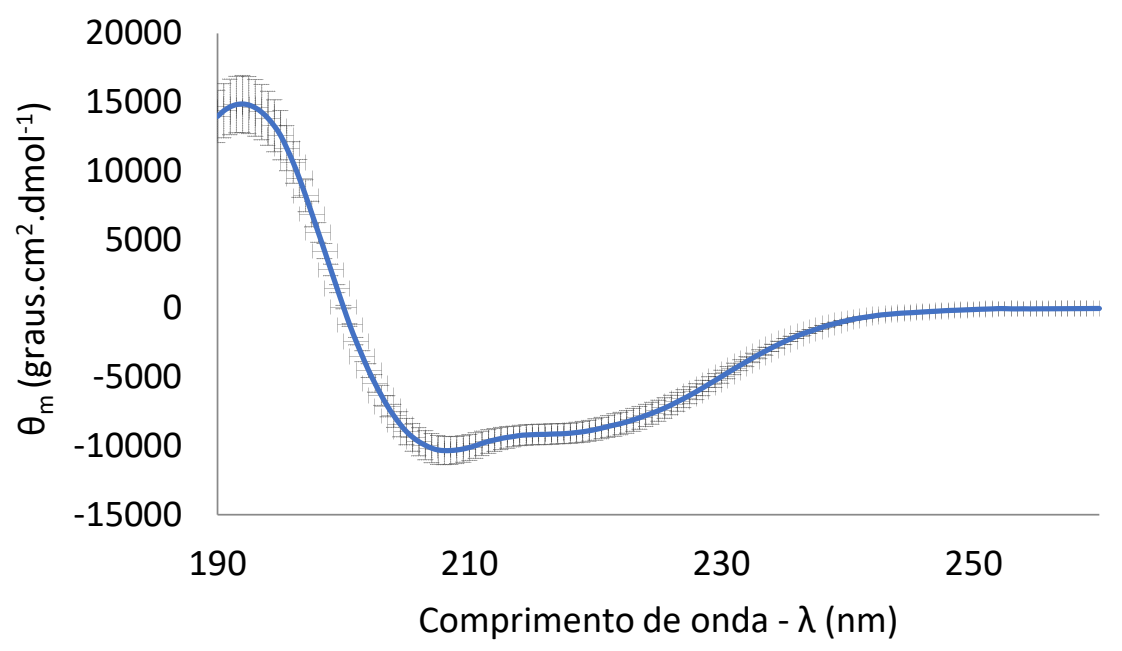

Fonte: Autoria própria.

Após tratamento dos dados obtidos, conforme equação 1, descrita na metodologia, e tratamento no programa CDNN Deconcolution®, utilizando a opção 13 basespectra de $205 \mathrm{~nm}$ a $260 \mathrm{~nm}$, cujo valor da somatória das estruturas secundárias foi mais próximo de $100 \%$, foi possível observar que a proteína obtida apresenta em média cerca de $31 \%$ de hélices $\alpha$ e $18 \%$ de fitas $\beta$. Nessa opção, o erro do programa é referido como sendo de 4,84\% (CDNN USER MANUAL).

Comparando os resultados obtidos para a CDK11 $\Delta$ com a modelagem molecular, e considerando o erro do CD, é possível dizer que o resultado obtido para a CDK11 $\Delta$ está dentro do esperado (Tabela 8), apesar de conter fitas $\beta$ acima do previsto, mas dentro do erro. Segundo GREENFIELD e FASMAN (1969), alguns conjuntos de dados tendem a superestimar fitas $\beta$ se houver dados menores que $208 \mathrm{~nm}$.

Tabela 8 - Comparação do percentual de estrutura secundária da CDK11 $\Delta$, obtido por diferentes metodologias.

\begin{tabular}{|c|c|c|}
\hline Estrutura secundária & $\begin{array}{c}\text { Modelagem } \\
\text { Hélices } \boldsymbol{\alpha}\end{array}$ & $\begin{array}{c}\text { Dicroísmo } \\
\text { Circular }\end{array}$ \\
\hline Folhas $\boldsymbol{\beta}$ & $15 \%$ & $31 \% \pm 4,84 \%$ \\
\hline & Fonte: Autoria própria. \\
\hline
\end{tabular}


Comparando os resultados obtidos com outras CDKs e considerando que as CDK2 e CDK9 compartilham com CDK11 , respectivamente, 45 e $38 \%$ de identidade, e considerando ainda que o domínio da quinase é altamente conservado entre as CDKs, observou-se que a CDK2 apresenta 33\% $\alpha$-hélice, 15\% $\beta$-folhas e 12\% $\beta$-voltas (código PDB: 5oo1), e a CDK9 30-34\% $\alpha$-hélice e 33-36\% $\beta$-folhas (LEOPOLDINO et al.,2006).

Os valores obtidos para CDK11 $\Delta$ estão próximos daqueles das CDK2 e CDK9, o que é mais um indicativo que, após o protocolo de reenovelamento, a CDK11 $\Delta$ apresentou a estrutura secundária esperada.

\subsubsection{Estabilidade da estrutura secundária após armazenamento da CDK11 $144^{\circ} \mathrm{C}$}

A avaliação da estabilidade de armazenamento a $4{ }^{\circ} \mathrm{C}$ por 70 dias da CDK1 $1 \Delta$ foi observada por dicroísmo circular (Figura 34A) e gel nativo (Figura 34B). A proteína foi armazenada em tampão Tris- $\mathrm{HCl} 20 \mathrm{mM}, \mathrm{NaCl} 50 \mathrm{mM}$, glicerol a 5\% (v/v), $10 \mathrm{mM} \beta$-mercaptoetanol, $\mathrm{pH} 7,4$.

Figura 34 - (A) Avaliação da estabilidade de armazenamento a $4{ }^{\circ} \mathrm{C}$ após 0,25 e 70 dias de CDK11 $\Delta$ por dicroísmo circular (B) CDK11 $\Delta$ de gel nativo após 70 dias. Uma única banda é observada.

(A)

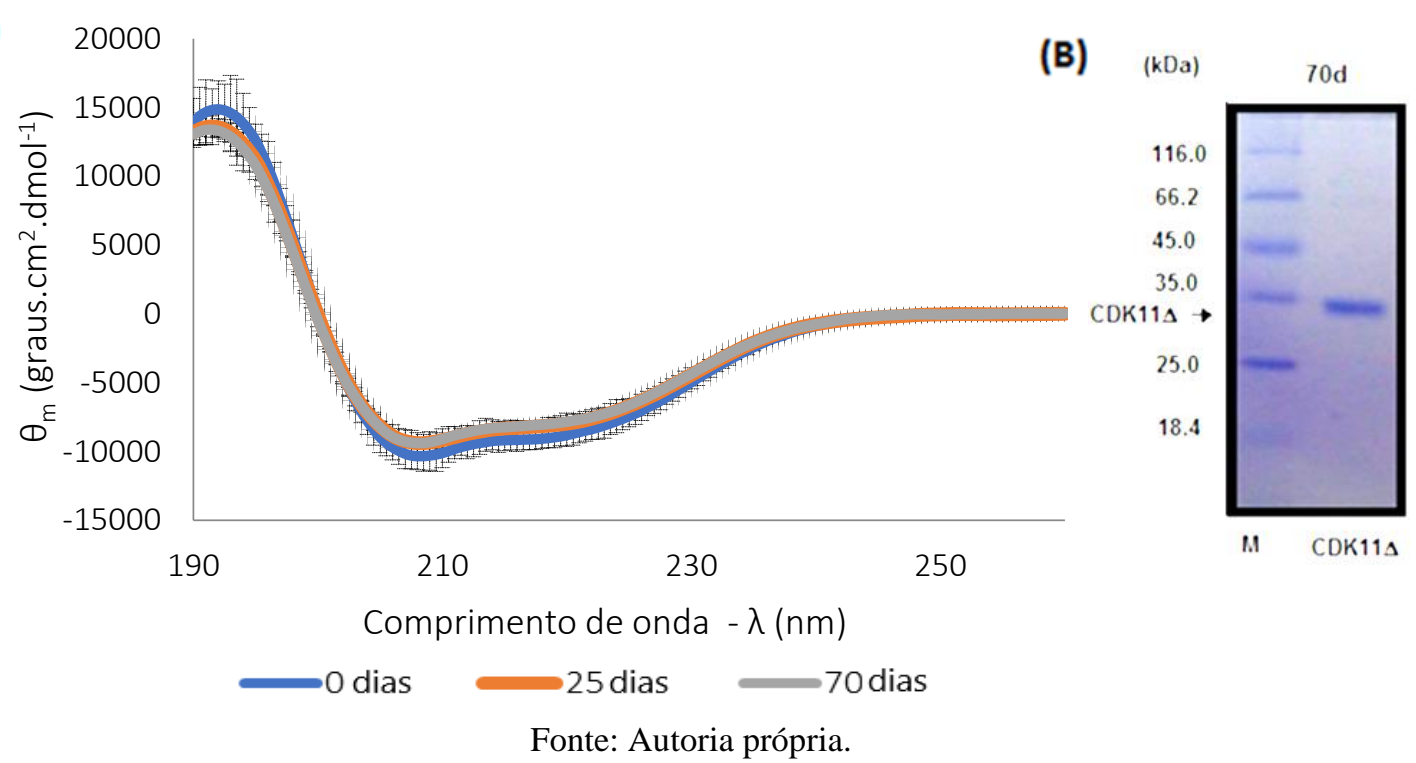

Esses resultados mostraram que a proteína tem estabilidade em sua estrutura secundária quando armazenada a $4{ }^{\circ} \mathrm{C}$ por até 70 dias. 


\subsubsection{Determinação da influência da concentração de CDK11 $\Delta$ na sua estrutura secundária}

Os espectros de dicroísmo circular, obtidos para a CDK11 $\Delta$, em diferentes concentrações podem ser observados na Figura 35.

Figura 35 - Espectro de dicroísmo circular para a CDK11 $1 \Delta$ utilizando diferentes concentrações da proteína em tampão Tris- $\mathrm{HCl} 20 \mathrm{mM}, \mathrm{NaCl} 50 \mathrm{mM}$, glicerol a $5 \%$ (v/v),

$10 \mathrm{mM} \beta$-mercaptoetanol e $\mathrm{pH}$ 7,4 diluído 20x.

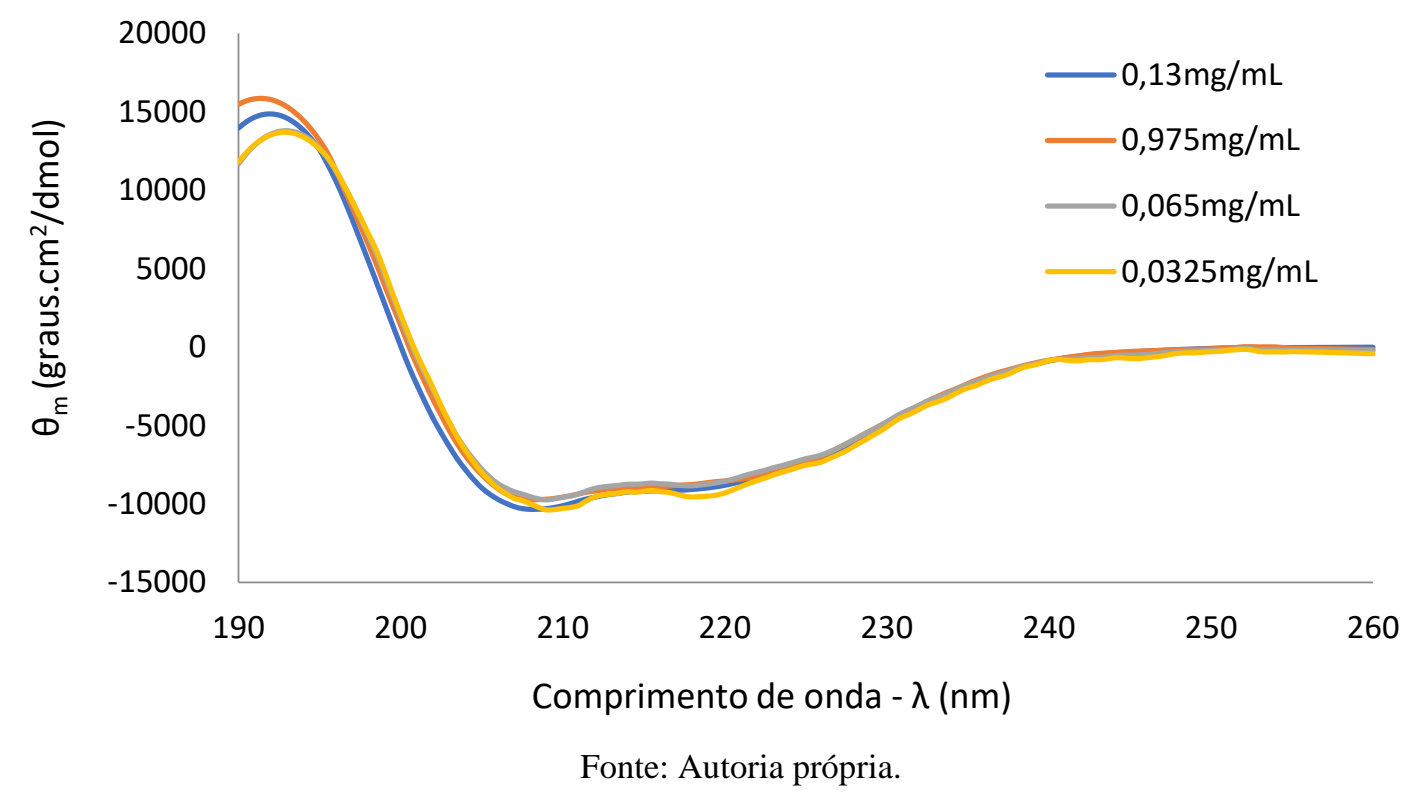

Após ajuste dos dados, de acordo com as concentrações, segundo equação 1, descrita na metodologia, pode ser observado na Figura 35 que os espectros estão próximos entre si, mostrando que não há alteração nas estruturas secundárias da proteína, para essas concentrações analisadas. As pequenas alterações, a comprimentos de ondas pequenos (abaixo de 200nm), são comuns, pois o oxigênio absorve luz, sendo indicado para esses comprimentos, o uso de água desgaseificada (KELLY, JESS e PRICE, 2005; GREENFIELD e FASMAN, 1969).

Para as diferentes concentrações, também foi calculado o percentual de estruturas secundárias e os valores calculados foram em média cerca de 30\% de hélices $\alpha$ e $19 \%$ de fitas $\beta$, o que está dentro do erro estabelecido pelo programa CDNN. 


\subsubsection{Determinação da influência da temperatura na estabilidade da estrutura secundária da CDK11 $\Delta$}

A análise de estabilidade térmica da CDK11 1 foi realizada monitorando a elipticidade molar no comprimento de onda fixo $222 \mathrm{~nm}$, aumentando a temperatura de $20{ }^{\circ} \mathrm{C}$ a $90{ }^{\circ} \mathrm{C}$, através de incrementos de $1{ }^{\circ} \mathrm{C}$ e retornando a $20{ }^{\circ} \mathrm{C}$. Os dados foram tratados com o encaixe de Boltzmann usando o programa Origin2019 (Figura 36).

Figura 36 - Avaliação da estabilidade térmica de CDK11 $\Delta$ por dicroísmo circular em $222 \mathrm{~nm}$. CDK11 $\Delta$ a 0,13 mg/mL em tampão Tris- $\mathrm{HCl} 20 \mathrm{mM}, \mathrm{NaCl} 50 \mathrm{mM}$, glicerol a 5\% (v/v), $10 \mathrm{mM}$ $\beta$-mercaptoetanol e $\mathrm{pH} 7,4$ diluído 20x. A temperatura de transição Tm foi de

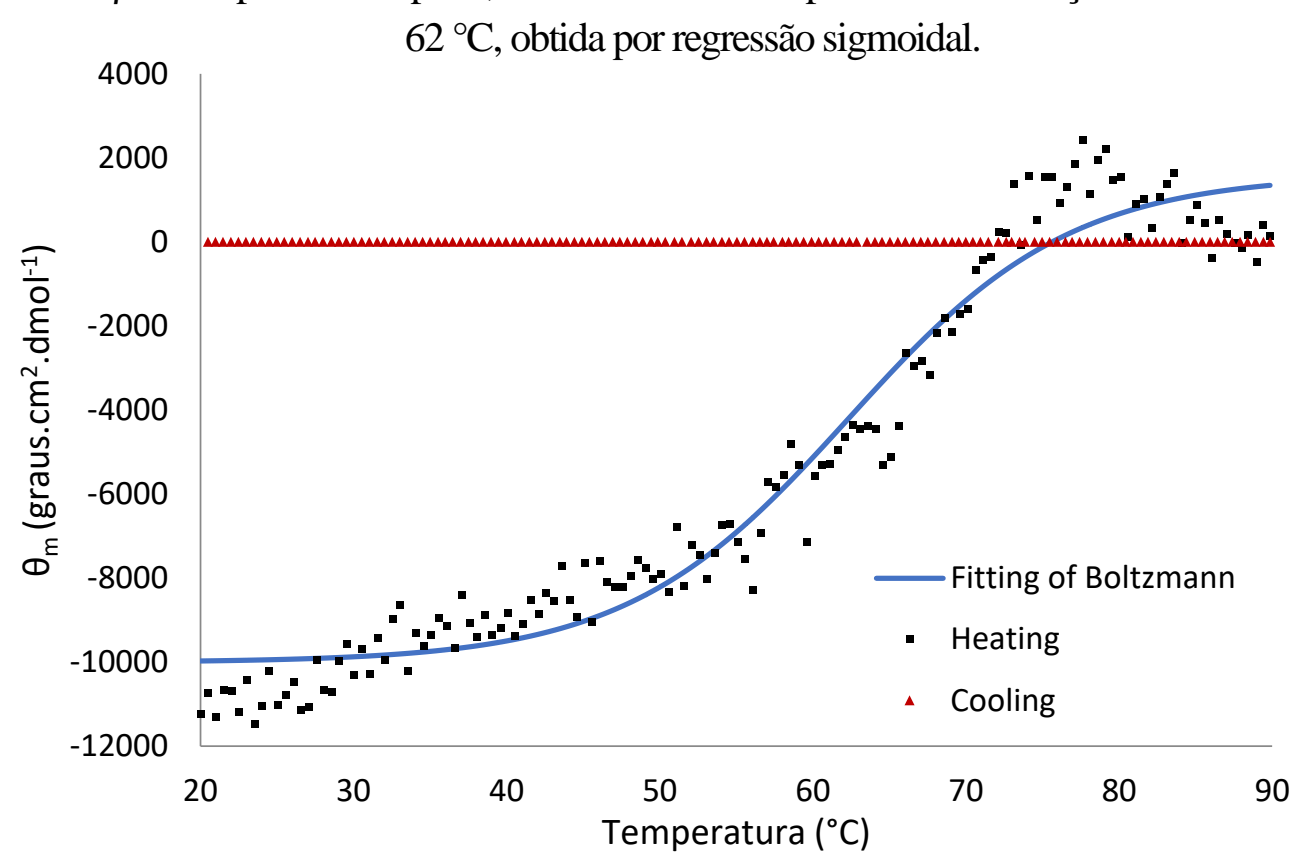

Fonte: Autoria própria.

Após o tratamento dos dados, foi possível observar que a proteína perde metade de suas estruturas secundárias em torno de $62{ }^{\circ} \mathrm{C}$ e seu reenovelamento não é reversível.

Esses dados foram confirmados por uma nova análise realizada em diferentes comprimentos de onda, aumentando a temperatura de 20 para $90{ }^{\circ} \mathrm{C}$, em incrementos de $5{ }^{\circ} \mathrm{C}$ (Figura 37). Esta análise mostra que a CDK11 $\Delta$ perde seu espectro característico em torno de $60{ }^{\circ} \mathrm{C}$. 
Figura 37 - Avaliação da estabilidade térmica de CDK11 $\Delta$ por dicroísmo circular em diferentes temperaturas.

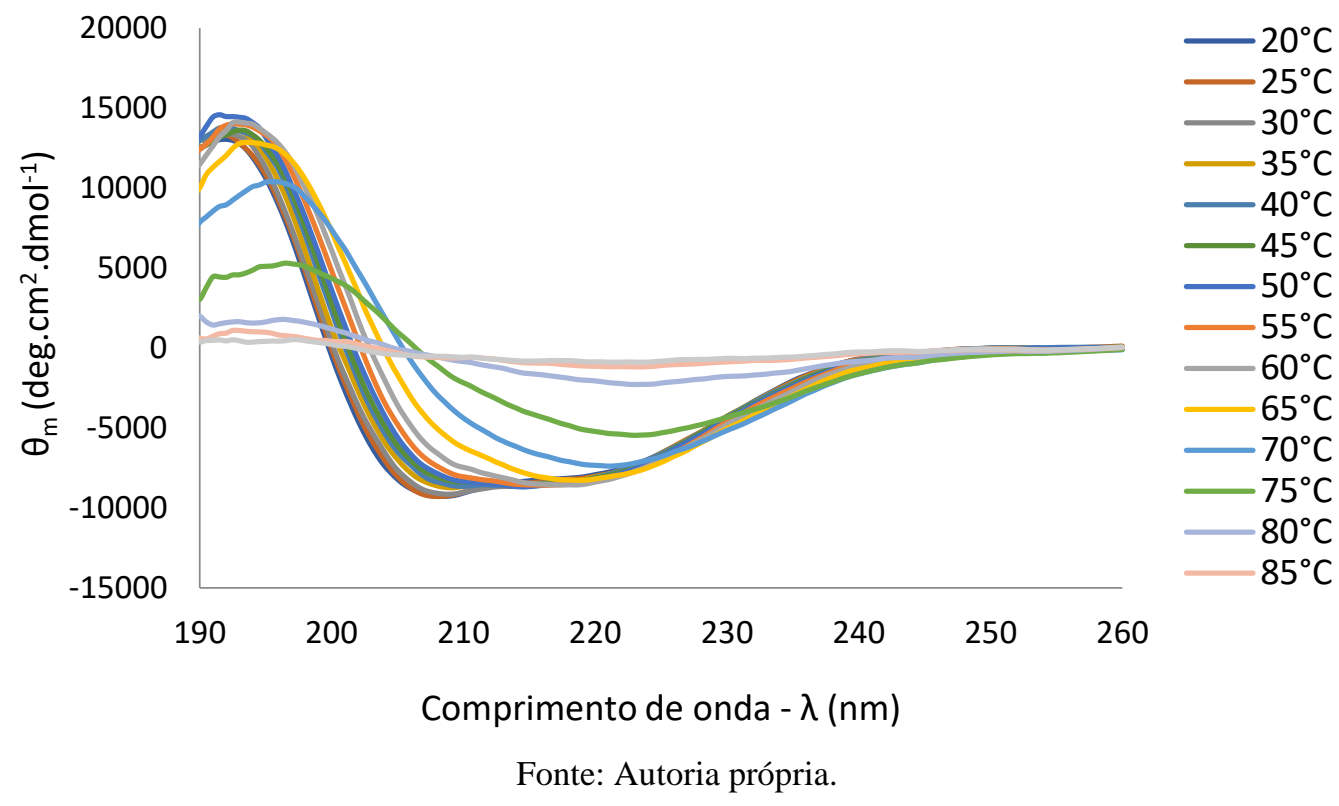

Esses dados são próximos aos obtidos por Brown et al. (2015) em que os autores encontraram $\mathrm{T}_{\mathrm{m}}$ em torno de $54{ }^{\circ} \mathrm{C}$ para CDK2 (CDK com o maior percentual de identidade sequencial em comparação com CDK11 $\Delta$ ).

\subsection{Espectroscopia de emissão de Fluorescência}

\subsubsection{Estudo da estabilidade química na presença de ureia}

O ambiente dos triptofanos presentes na CDK11 $1 \Delta$ em diferentes concentrações de ureia foi monitorado por fluorescência.

Mudanças no perfil de emissão da fluorescência atuam como uma sonda para trazer informações sobre a estrutura terciária da proteína. Máximos de emissão em torno de 330nm são típicos de triptofanos internalizados na proteína (proteína enovelada), enquanto máximos em torno de $350 \mathrm{~nm}$ são típicos de triptofanos expostos ao solvente (proteína desenovelada) (LAKOWICZ, 2006).

Para a CDK11ه (Figura 38) pode ser observado o deslocamento de seus máximos, de $336 \mathrm{~nm}$ para $348 \mathrm{~nm}$, com o aumento da concentração de ureia, mostrando que a proteína é desnaturada na presença desse composto a partir de $4 \mathrm{M}$ de ureia. 
Figura 38 - Espectro de emissão de fluorescência para CDK11 $\Delta$ frente a diferentes concentrações de ureia (de $0 \mathrm{M} \mathrm{a} 6 \mathrm{M})$.

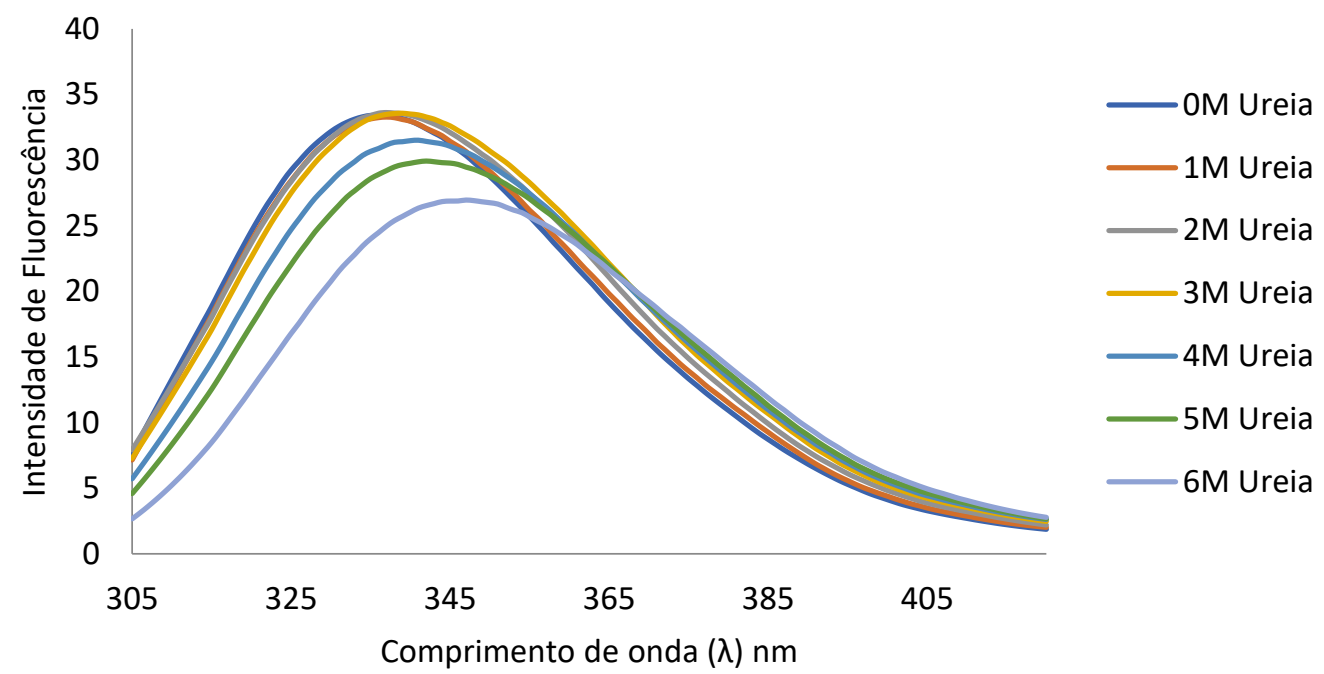

Fonte: Autoria própria.

\subsubsection{Estudo da interação da CDK11 $\Delta$ com ATP}

Proteínas quinases são conhecidas por interagirem com o ATP e transferirem o fosfato $\gamma$ dessa molécula para sua proteína alvo. No entanto, as quinases dependentes de ciclinas (CDKs), como o próprio nome diz, necessitam da ciclina para transferir este fosfato do ATP para sua proteína alvo. Nesse contexto, um teste de atividade confirmaria a obtenção da estrutura nativa da proteína, porém o presente estudo não prevê a obtenção da ciclina. Porém, mesmo sem sua parceira ciclina, a CDK pode se ligar ao ATP. Assim, é possível, estudando a interação da CDK11 $\Delta$ com o ATP, averiguar se a proteína, obtida a partir da expressão heteróloga, está interagindo com seu ligante natural ATP.

Para isso optou-se pelo estudo de sua interação com o ATP por espectroscopia de emissão de fluorescência. A interação da CDK11 $\Delta$ com o ATP foi estudada por essa técnica, pois, quando há interação, ocorre a diminuição da fluorescência (LAKOWICZ, 2006).

Os ensaios de fluorescência foram realizados com excitação inicialmente a $295 \mathrm{~nm}$, referente aos triptofanos, mas não ocorreu a supressão com o aumento da concentração do ATP (resultados não mostrados), assim a excitação foi feita em $280 \mathrm{~nm}$, que corresponde as tirosinas e triptofanos. 
O motivo da supressão ter ocorrido apenas quando foram analisadas as tirosinas foi observado após modelagem molecular feita no MODELLER. Note na Figura 39 o modelo da CDK11 (cinza) ligado ao ATP (verde), na Figura 39A, destaca-se os resíduos de triptofano em vermelho, note que eles estão distantes do bolsão de ligação do ATP não causando assim interferência na supressão com ATP. Enquanto na Figura 12B, vemos que há vários resíduos de tirosina em azul próximas ao ATP, causando assim interferência na sua fluorescência com a presença do ligante.

Figura 39 - Modelo da CDK11 $\Delta$ (cinza) após inserção do ligante ATP (verde) onde em (A) destaca-se os triptofanos em vermelho e em (B) as tirosinas em azul.
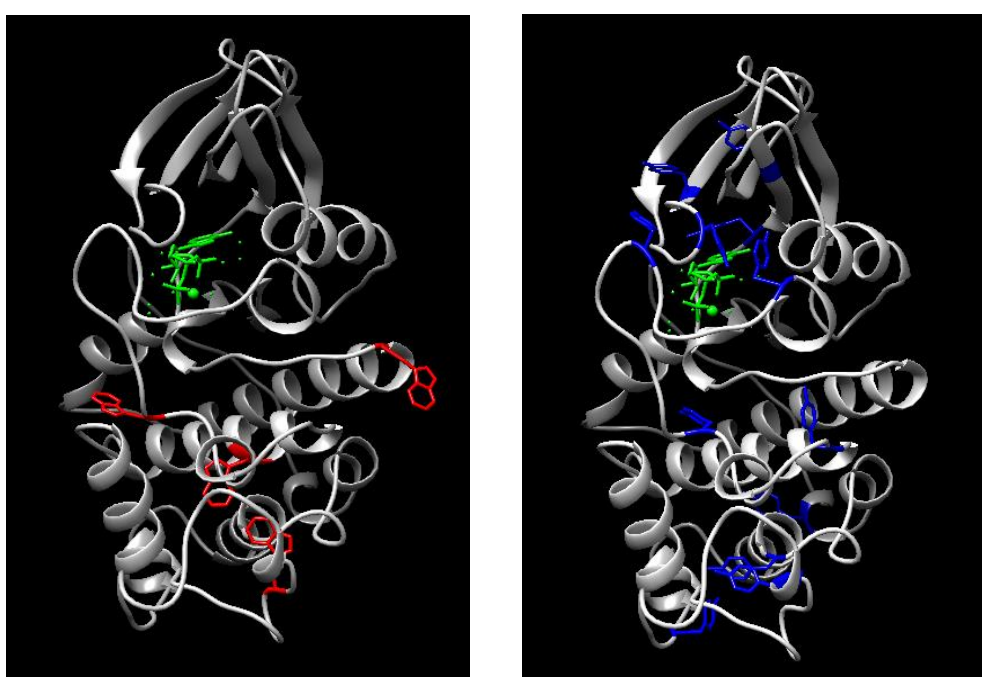

Fonte: Autoria própria.

O espectro de emissão de fluorescência da CDK11 frente a diferentes concentrações de ATP (Figura 40) mostra que, com o aumento da concentração do ATP ocorre a supressão da fluorescência, confirmando que a proteína de interesse está interagindo com seu ligante. 
Figura 40 - Espectro de emissão de fluorescência para CDK11 $\Delta$ frente a diferentes concentrações de ATP.

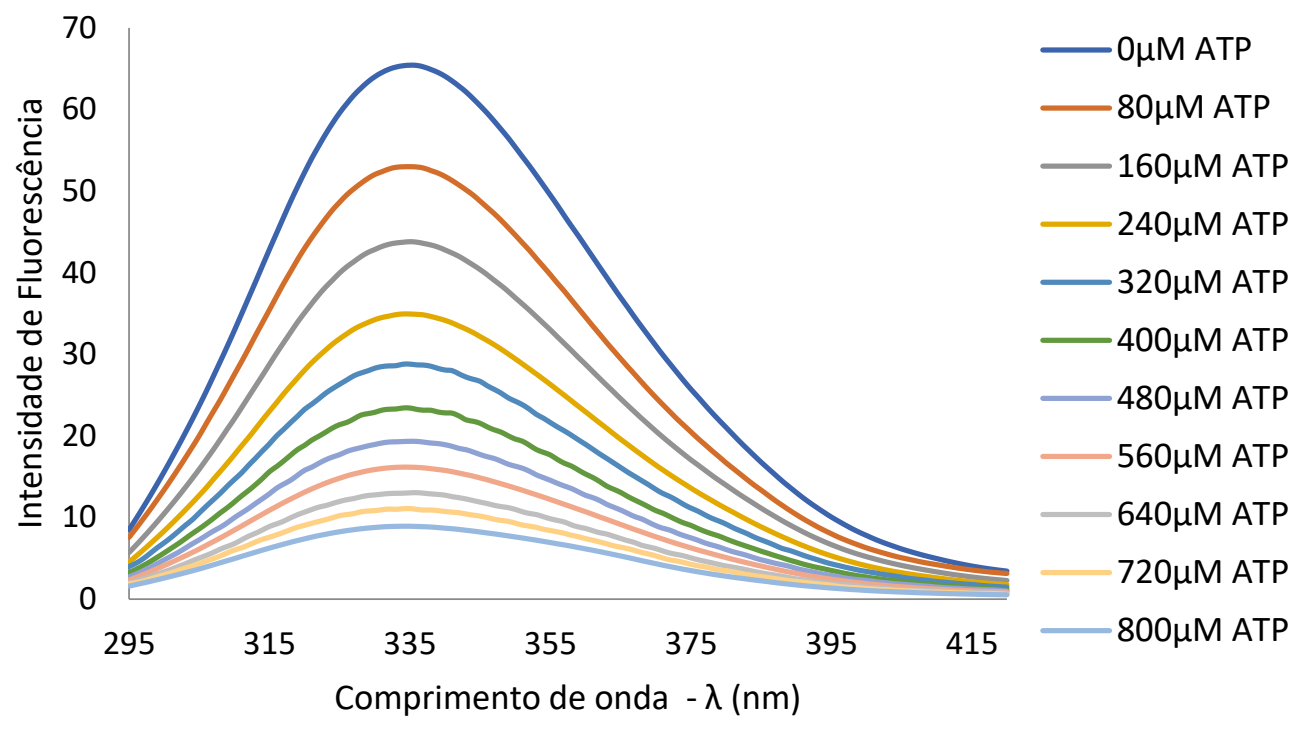

Fonte: Autoria própria.

Estudando a supressão dessa fluorescência, foi observado que pode ocorrer dois tipos de supressão:

- Colisional (ou dinâmica) - o supressor se difunde no fluoróforo durante seu estado excitado e, após o contato, o fluoróforo retorna para seu estado fundamental sem emitir um fóton.

- Estática - ocorre a formação de um complexo não fluorescente no estado fundamental entre o fluoróforo e o supressor.

Além de ocorrer de forma exclusiva, as supressões dinâmica e estática também podem ocorrer combinadas, e isso pode ser observado, traçando um gráfico [Q] (concentração do supressor) versus $F_{0} / F$ ( $F_{0}=$ intensidade máxima de fluorescência inicial e F = intensidade máxima de fluorescência após supressão naquela concentração do supressor). Quando esse gráfico não é linear os processos estão combinados, mas quando é linear eles são exclusivos (Figura 41) (LAKOWICZ, 2006). 
Figura 41 - Gráficos típicos para as supressões (A) colisional e (B) estática (C) estática e colisional.

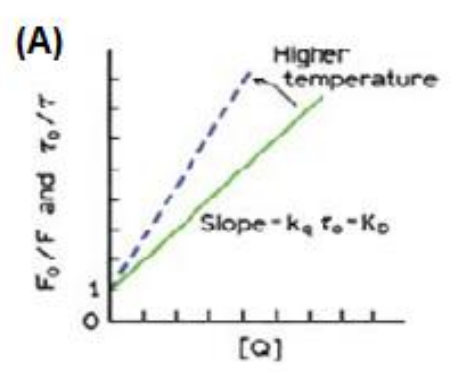

(B)

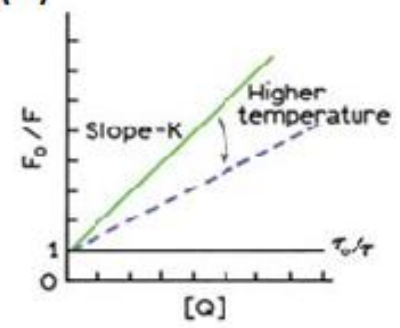

(C)

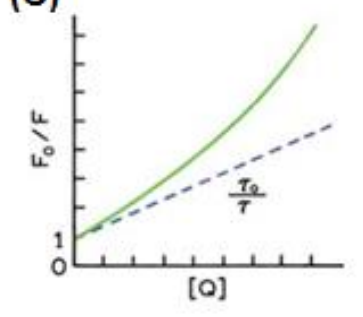

Fonte: LAKOWICZ, 2006.

Para a CDK $11 \Delta$ com o ATP o gráfico $F_{0} / F$ versus [Q] mostrou uma curvatura (Figura 42), indicando que há uma combinação da supressão colisional e da estática entre a CDK11 11 e o ATP.

Figura 42 - Gráfico Fo/F versus [Q] para a CDK11 $\Delta$ em função da concentração de ATP.

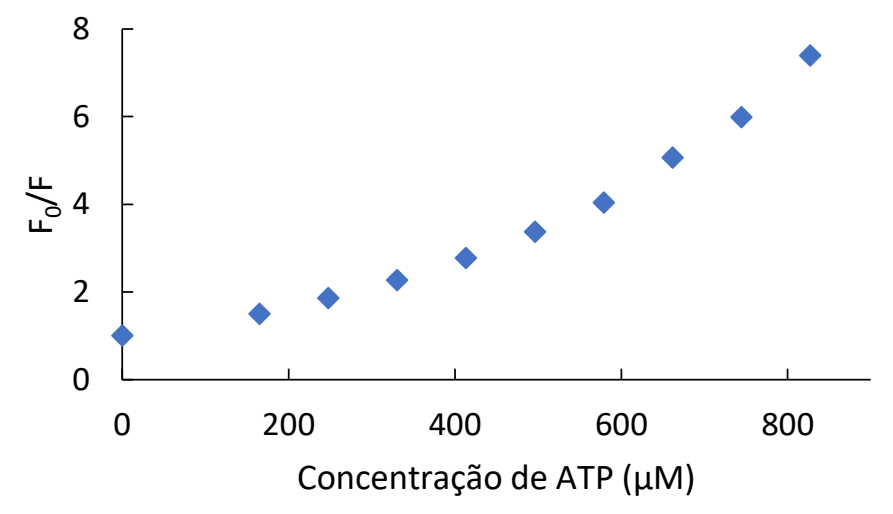

Fonte: Autoria própria.

Além disso, utilizando a equação 3 , um gráfico de $\log \left(\mathrm{F}_{0}-\mathrm{F} / \mathrm{F}\right)$ versus $\log [\mathrm{Q}]$ (Figura 43), fornece em seu coeficiente linear $\log K_{a}$, e em seu coeficiente angular $n$. Sendo $\mathrm{K}_{\mathrm{a}}$ a constante de associação proteína ligante e $\mathrm{n}$ o número de sítios ligantes (MOREIRA et al., 2015 e PRADO, 2017).

$$
\log \left\{\frac{F_{0}-F}{F}\right\}=\log K_{a}+n \log [Q] \quad \text { Equação } 3
$$


Figura 43 - Gráfico $\log \left(\mathrm{F}_{0}-\mathrm{F} / \mathrm{F}\right)$ versus $\log [\mathrm{ATP}]$ para a $\mathrm{CDK} 11 \Delta$ e seu respectivo ajuste linear.

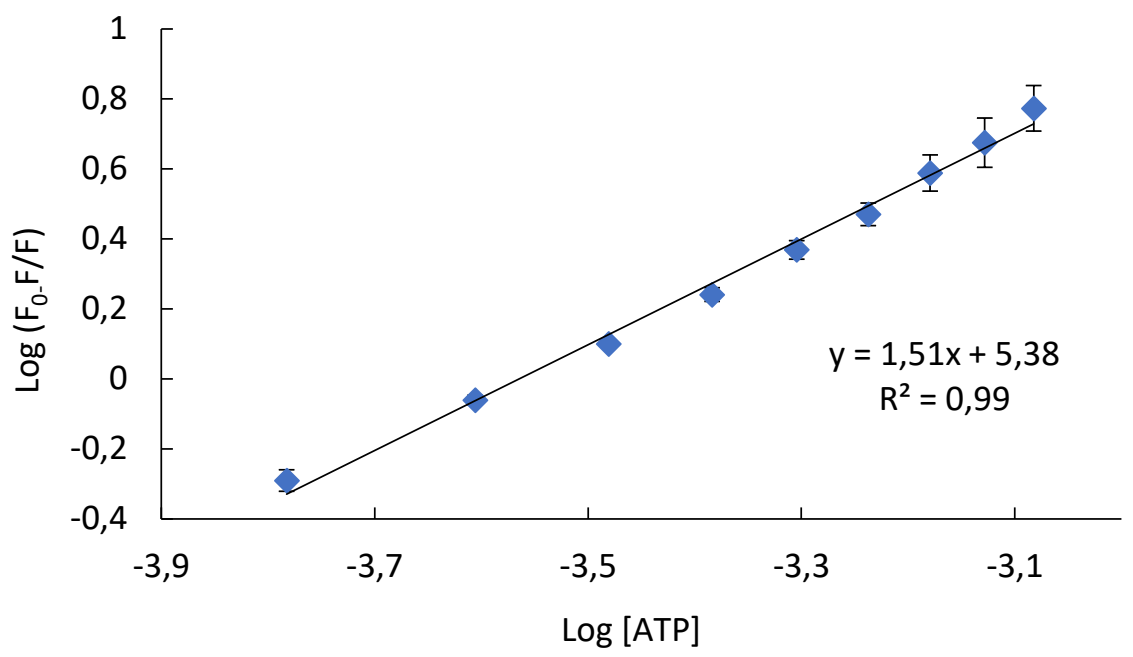

Fonte: Autoria própria.

Para a CDK11 $\Delta, n=1,51$ e $K_{a}=2,42.10^{5} \mathrm{M}^{-1}$. Sendo o valor previsto de $\mathrm{n}$ em torno de um, o desvio desse valor pode significar alguma interação inespecífica além da interação no sítio ativo. Quanto ao valor de $\mathrm{K}_{\mathrm{a}}$ é consenso na literatura classificar constantes de associação menores que $10^{4}$ como fracas, de $10^{4}$ a $10^{6}$ como moderadas e maior de $10^{7} \mathrm{M}^{-1}$ como fortes (PRADO, 2017). Para a CDK11 $\Delta$ com ATP foi moderada.

Além disso, com o inverso de $\mathrm{K}_{\mathrm{a}}$, podemos determinar $\mathrm{K}_{\mathrm{d}}$, conhecido como constante de dissociação, o $\mathrm{K}_{\mathrm{d}}$ para a CDK11 1 e ATP é de 4,13 $\mu \mathrm{M}$. O $\mathrm{K}_{\mathrm{d}}$ é definido como a concentração necessária do fármaco para atingir $50 \%$ de ocupação dos seus receptores. Como $\mathrm{K}_{\mathrm{d}}$ mede a tendência de um ligante de se dissociar da proteína, quanto maior $\mathrm{K}_{\mathrm{d}}$, maior a tendência do ligante se desligar da proteína indicando menor afinidade entre a proteína e o ligante (PRANDO, 2012).

Esse parâmetro pode ser utilizado para comparações da afinidade de potenciais inibidores frente a $\operatorname{CDK} 11 \Delta$, visto que potenciais inibidores, nesse caso, devem apresentar maior afinidade com a proteína (maior $\mathrm{K}_{\mathrm{a}}$ e menor $\mathrm{K}_{\mathrm{d}}$ ).

\subsubsection{Estudo da interação da CDK11 $\Delta$ com roscovitine}

Para a CDK11 $\Delta$ com a roscovitina o gráfico $F_{0} / F$ versus [Q] também mostrou uma curvatura (Figura 44), indicando que também ocorreu uma combinação da supressão colisional e da estática. 
Figura 44 - Gráfico $F_{0} / F$ versus [Q] para a CDK11 $\Delta$ em função da concentração de roscovitina.

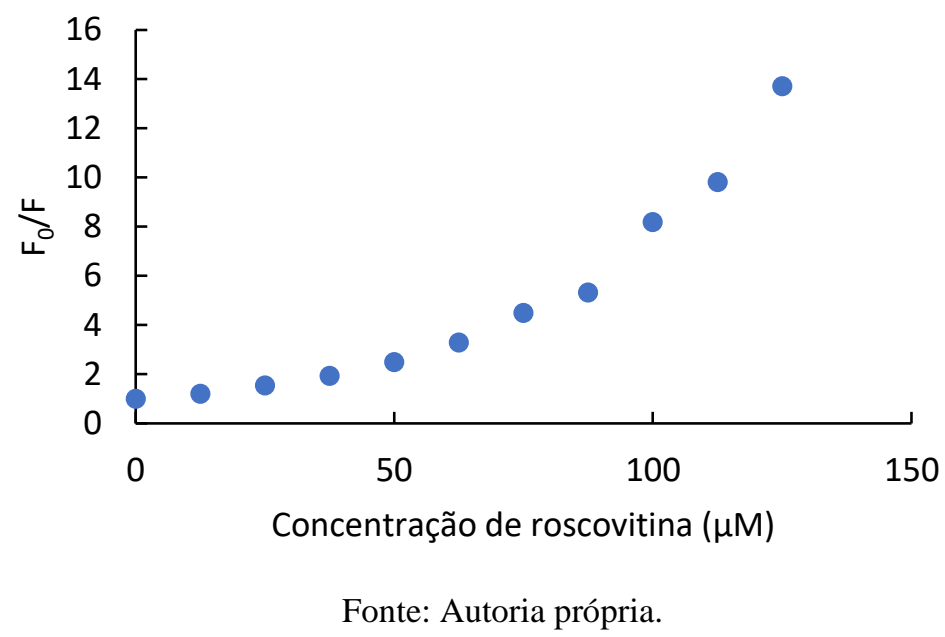

Além disso, utilizando a equação 3 gerou-se um gráfico de $\log \left(\mathrm{F}_{0}-\mathrm{F} / \mathrm{F}\right)$ versus $\log [$ roscovitina] (Figura 45).

Figura 45 - Gráfico $\log \left(\mathrm{F}_{0}-\mathrm{F} / \mathrm{F}\right)$ versus $\log [$ roscovitina $]$ para a CDK11 e seu respectivo ajuste linear.

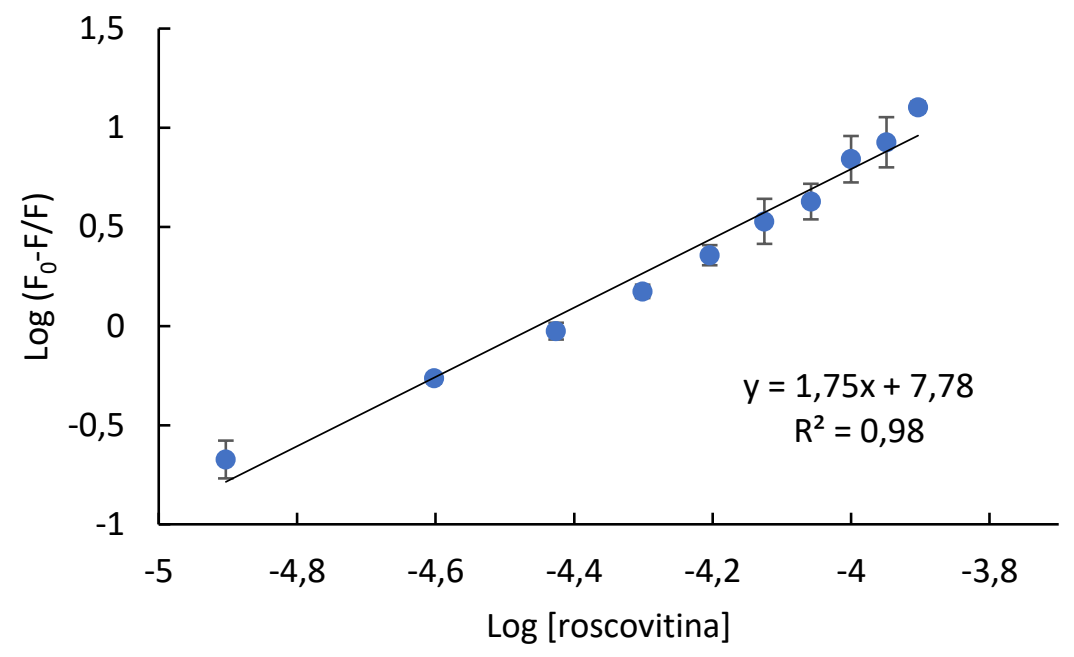

Fonte: Autoria própria.

Após tratamento dos dados obteve-se $\mathrm{n}=1,75$ e $\mathrm{K}_{\mathrm{a}}=5,98.10^{7} \mathrm{M}^{-1}$. Assim como para o ATP, o valor previsto de n é em torno de um e o desvio desse valor pode significar alguma interação inespecífica além da interação no sítio ativo. Quanto ao valor de $\mathrm{K}_{\mathrm{a}}$, observa-se um valor de $\mathrm{K}_{\mathrm{a}}$ maior que $10^{7} \mathrm{M}^{-1}$ indicando uma interação forte entre roscovitina e CDK11 $1 \Delta$.

$\mathrm{O}$ valor de $\mathrm{K}_{\mathrm{a}}$ aqui encontrado é maior do que o encontrado para o ATP indicando que a CDK11 liga-se mais fortemente à roscovitina do que ao ATP. Esse resultado 
indica que esse ligante é um promissor candidato a inibidor da CDK11, no entanto, sendo necessário mais estudos.

Já se sabe que a roscovitina interage com várias CDKs, sendo um inibidor promissor para as CDK1, CDK2, CDK5, CDK7 e CDK9 mas é um fraco inibidor para as CDK4, CDK6 e CDK8 (CICENAS et al., 2015), mas esse é o primeiro estudo envolvendo a roscovitina e a CDK11.

Em nosso estudo o $\mathrm{K}_{\mathrm{d}}$ obtido está na ordem de $17 \mathrm{nM}$, valor próximo aos potenciais inibidores relatados para a CDK11 como a cortistatina $A$, com um $\mathrm{K}_{\mathrm{d}} \mathrm{de}$ 10 nM (CEE et al., 2009) e o agente anticâncer OTS964, com um $K_{d}$ de 40nM (LIN et al,. 2019).

No entanto, apesar dos resultados promissores da roscovitina em monoterapia em muitos estudos pré-clínicos, nos ensaios clínicos esse composto não mostrou resultados promissores, sendo o uso de terapias combinadas mais promissor (CICENAS et al., 2015).

Por exemplo, o uso combinado de baixas concentrações de paclitaxel (2,5 a $5 \mathrm{nM})$ com roscovitina mostrou-se promissor para o tratamento do câncer de cólon e da tireóide anaplásico (PUSHKAREV et al., 2012).

Além disso, o agente anticâncer OTS964 que atua na CDK11, quando usado no tratamento de câncer mostrou ser passível de adquirir resistência, no entanto as células resistentes a esse fármaco permaneciam sensível ao paclitaxel (LIN et al. 2019), o que indica o uso de terapia combinada como um futuro promissor quando o foco é a CDK11.

Derivados de roscovitina também são uma futura esperança, no entanto mais informações sobre a relação estrutura-atividade devem ser exploradas e melhor caracterizadas (CICENAS et al., 2015).

A obtenção dessa proteína em uma versão encurtada poderá então ser promissora para utilização desse protocolo para testes com sua parceira ciclinas e determinações de constantes de inibição da CDK11.

Além da possibilidade de utilizar a proteína obtida em busca de estruturas cristalográficas com e sem ligante que propicie informações crucias na busca de um inibidor efetivo para a CDK11.

Outra possibilidade é o uso dessa proteína, que foi obtida a partir de expressão heteróloga com um baixo custo se comparado à expressão em sistemas eucarióticos, alto rendimento e alta pureza para o desenvolvimento de kits de detecção da CDK como um potencial biomarcadores visando o uso de terapia direcionada. 


\subsection{Bioinformática}

\subsubsection{Modelagem molecular da CDK11 $\Delta$}

\subsubsection{SWISS-MODEL}

Dentre os 5188 moldes encontrados, as 50 estruturas com maior similaridade, para a CDK11 1 , foram mostradas. Elas possuem identidade sequencial maior que $40 \%$ quando comparadas a CDK11 $1 \Delta$ e dentre elas, a CDK2 possui o maior percentual de identidade.

Além da CDK2, foram encontradas, com identidade sequencial maior que 40\%, outras CDKs, tais como, CDK1, CDK7, CDK9, CDK12, CDK13 e CDK16, algumas com e outras sem ciclina, sendo apenas a CDK2 encontrada com e sem suas ciclinas associadas.

A fim de avaliar se os modelos gerados a partir de moldes com ciclina e de molde sem ciclinas teriam diferenças no loop $\mathrm{T}$ foram selecionados moldes para a geração de modelos com base em diferentes CDKs, considerando para cada CDK a estrutura com maior cobertura e identidade sequencial.

Para as estruturas associadas a ciclina, selecionou-se os moldes 5efq (CDK13), 5acbv (CDK12), 4ogr (CDK9) e 1vyw (CDK2), já para as estruturas sem ciclina, selecionou-se 6gu7 (CDK1), 5g6v (CDK16), 1ua2 (CDK7) e 5osm (CDK2). Após a geração dos modelos pelo programa SWISS-MODEL, foi feita a sobreposição das estruturas geradas utilizando o programa PyMOL, para as estruturas com ciclina (Figura 46A) e sem ciclina (Figura 46B).

Como pode ser observado, o loop T (círculo em vermelho na figura 46), adotou uma conformação aberta para todas as estruturas que foram geradas em base de CDKs com ciclina e uma conformação fechada para as estruturas geradas em base de CDKs sem ciclina, confirmando que as CDKs possuem diferenças conformacionais na ausência ou na presença de sua parceira ciclina. 
Figura 46 - Sobreposição dos modelos gerados (A) em base de CDKs com ciclina. Ciano: código PDB 5efq-CDK13, roxa: código PDB 5acb -CDK12, amarela: código PDB 4ogr-CDK9 e verde: código PDB 1vyw - CDK2. (B) em base de CDKs sem ciclina, ciano: código PDB 6gu7 (CDK1), roxa: código PDB 5g6v (CDK16), amarela: código PDB 1ua2 (CDK7) e verde: código PDB 5osm (CDK2). Em vermelho destaca-se o loop T, que varia sua conformação quando a CDK está ou não associada a ciclina, em A, conformação aberta e em B conformação fechada.
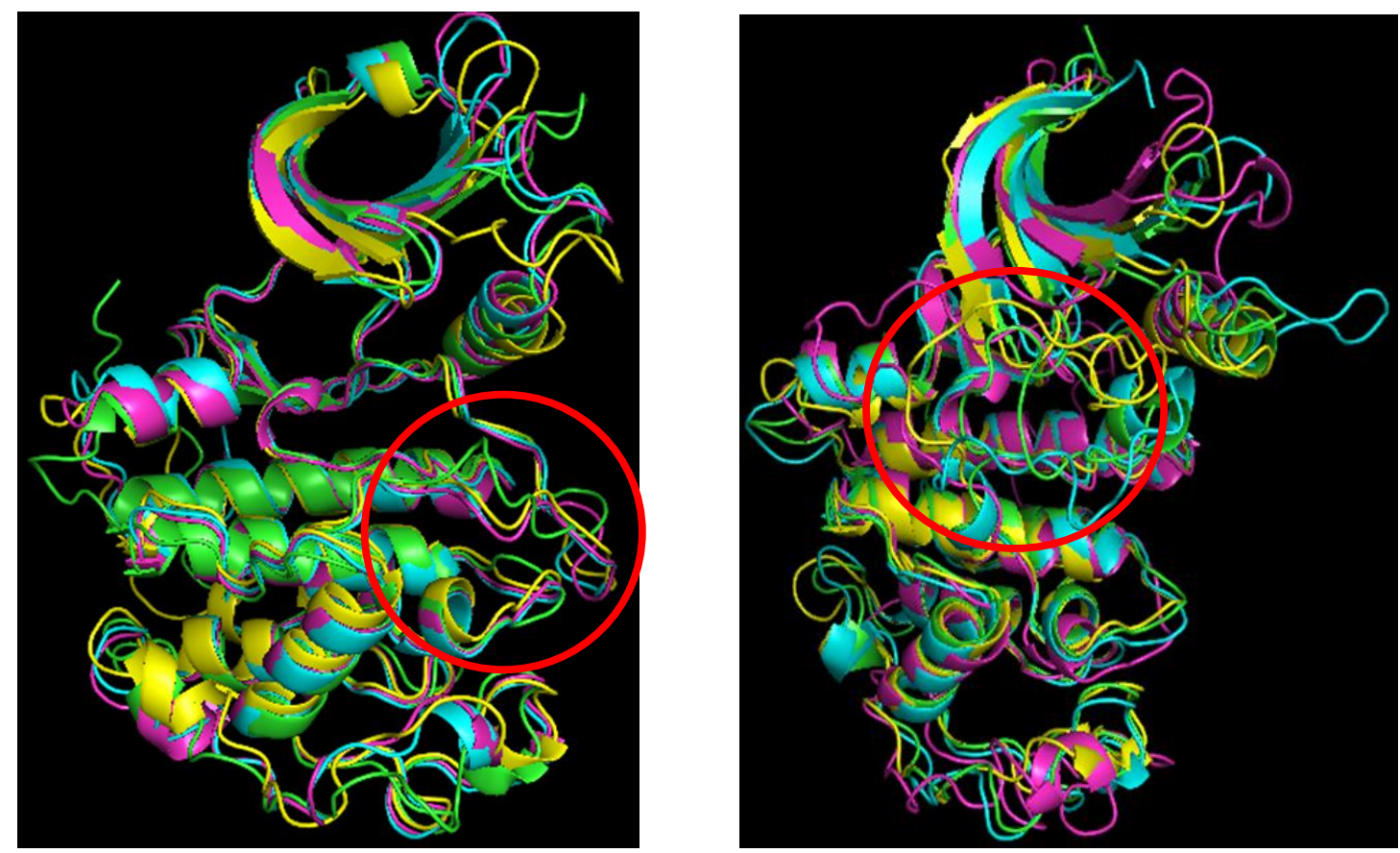

Fonte: Autoria própria.

Sendo assim, dentre os modelos sugeridos consideramos apenas modelos gerados com moldes contendo CDKs sem a ciclina, pois é a forma como a CDK11 $\Delta$ foi obtida nos nossos experimentos (sem sua parceira ciclina).

Juntamente com o modelo gerado a ferramenta SWISS-MODEL disponibilizou duas funções para avaliação dos modelos gerados: a função de pontuação QMEAN que deve ser maior do que -4.0 para representar um modelo de boa qualidade e a função GMQE (Global Model Quality Estimation), cuja pontuação (entre 0 e 1) reflete uma maior confiabilidade, quanto mais próxima de 1.

Essas funções nos permitiram escolher o melhor modelo para a $\operatorname{CDK} 11 \Delta$, como sendo aquele que apresentou GMQE mais próximo de 1 e QMEAN maior. Esse modelo foi baseado na estrutura de código PDB 5osm, referente a CDK2, com identidade sequencial de $45.89 \%$, cobertura de $93 \%$ e resolução de $1,77 \AA$ A. A modelagem da CDK11 $1 \Delta$ a partir dessa estrutura possui $31 \%$ de hélices alfa e $15 \%$ de fitas betas, e pode ser observada na Figura 47. 
Figura 47 - Modelagem molecular comparativa da CDK11 $\Delta$ a partir da CDK2 (código PDB: 5osm).

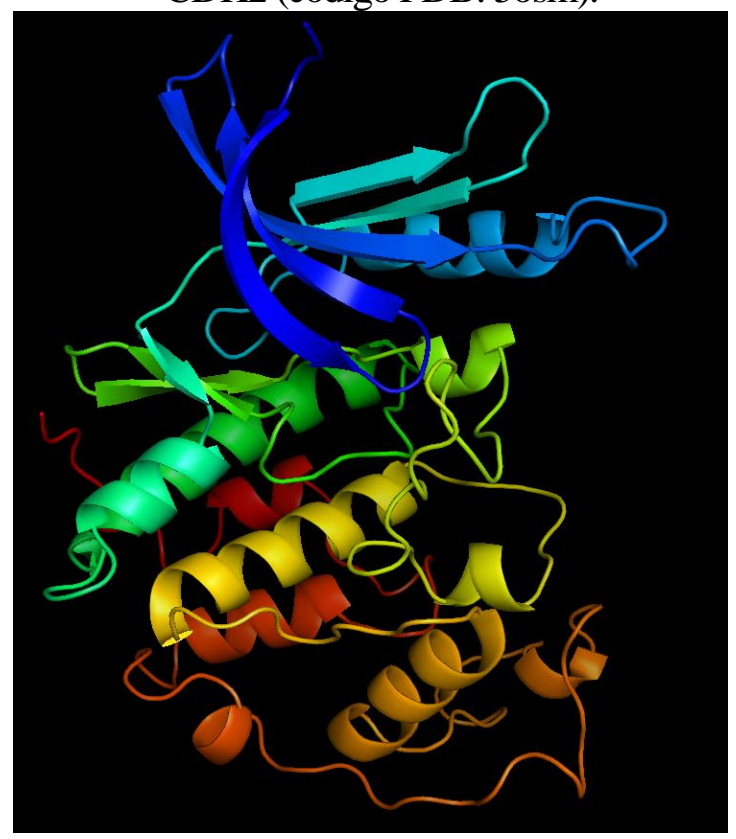

Fonte: Autoria própria.

Na tabela 9, também pode ser observado o percentual de elementos de estrutura secundária dos modelos gerados com base nos moldes de outras CDKs sem ciclina.

Tabela 9 - Percentual de estrutura secundária da CDK11 $\Delta$ modelada a partir de diferentes moldes.

\begin{tabular}{|c|c|c|}
\hline Proteína do molde & $\begin{array}{r}\text { \% de fitas } \boldsymbol{\beta} \text { do modelo } \\
\text { gerado }\end{array}$ & $\begin{array}{c}\text { \% de hélice } \boldsymbol{\alpha} \text { o modelo } \\
\text { gerado }\end{array}$ \\
\hline CDK2 & 13,4 & 32,8 \\
\hline CDK1 & 14,0 & 35,0 \\
\hline CDK7 & 13,0 & 31,8 \\
\hline CDK16 & 12,7 & 30,6 \\
\hline
\end{tabular}

Fonte: Autoria própria.

\subsubsection{I-TASSER}

Para cada modelo gerado, as simulações I-TASSER gerou um escore $\mathrm{C}$, que vai de -5 a 2, em que um valor maior significa maior confiança no modelo gerado.

Para a CDK11 delta foram fornecidos 3 principais modelos, denominados modelo 1 , modelo 2 e modelo 3 , com escore $C$, respectivamente de 0,$7 ;-0,18$ e 0,74.

A análise da alça T, no programa Pymol, por sobreposição dos modelos gerados, mostrou que todos os modelos gerados possuem a alça T em conformação aberta (Figura 48), que corresponde a CDK com ciclina, isso ocorreu, pois o servidor escolhe 
automaticamente os moldes e como as estruturas com ciclinas são mais abundantes e geralmente possuem melhores resoluções, elas foram as escolhidas. Nesse contexto, esse programa não foi adequado para o nosso estudo, já que objetivamos analisar a CDK11 $\Delta$ sem sua parceira ciclina.

Figura 48 - Sobreposição dos modelos gerados pelo programa I-TASSER. Modelo 1 (verde), modelo 2 (ciano) e modelo 3 (roxo). Em vermelho destaca-se o loop T em conformação aberta.

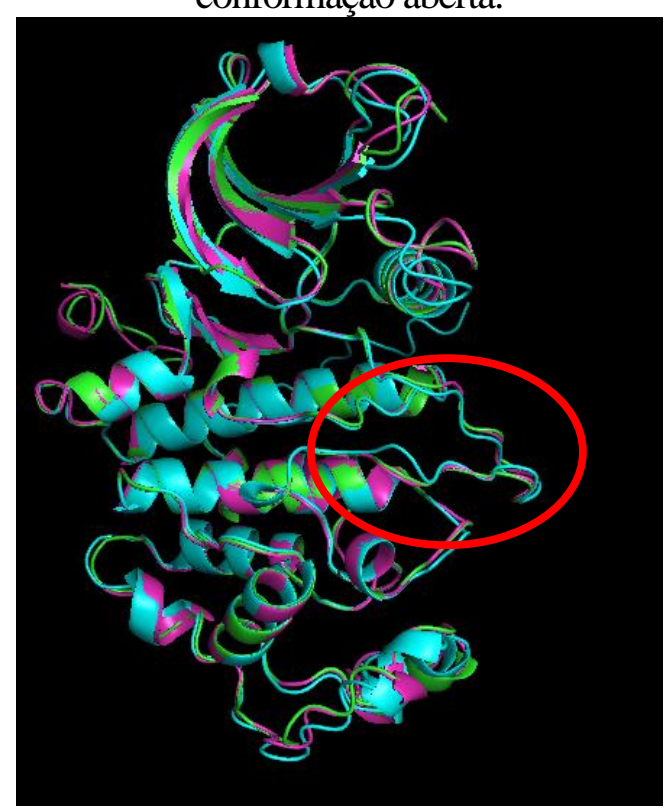

Fonte: Autoria própria.

\subsubsection{MODELLER}

A pesquisa no MODELLER encontrou várias estruturas de quinases não humanas e apenas duas CDKs humanas sem ciclina, a CDK2 (código PDB 1gz8) e a CDK7 (código PDB 1ua2).

Devido ao baixo número de estruturas de CDKs encontradas pelo MODELLER, realizou-se uma busca no BLAST, filtrando as estruturas presentes no PDB de CDKs mais próximas sequencialmente a $\operatorname{CDK} 11 \Delta$.

No BLAST foram encontradas diversas estruturas de CDKs com mais de $40 \%$ de identidade sequencial, sendo a CDK2, de código PDB 5oo1, a de maior identidade $(45,30 \%)$. 
Devido ao grande número de CDKs encontradas no BLAST, realizamos duas modelagens com múltiplos moldes. Em ambas, foram inseridas as duas CDKs encontradas no MODELLER (de código PDBs 1gz8 e 1ua2) e a CDK2 de maior identidade sequencial encontrada no BLAST (de código PDB 50o1).

A primeira modelagem foi denominada "MODELLER com diferentes CDKs", pois foram inseridas as CDKs sem ciclina (CDK5 e CDK6), encontradas no BLAST. As principais características dos moldes utilizados nessa modelagem podem ser observadas na Tabela 10.

Tabela 10 - Principais características dos moldes utilizados na modelagem denominada "MODELLER com diferentes CDKs".

\begin{tabular}{|c|c|c|c|c|c|}
\hline $\begin{array}{c}\text { Programa } \\
\text { utilizado para } \\
\text { definir molde }\end{array}$ & Proteína & $\begin{array}{c}\text { Código } \\
\text { PDB }\end{array}$ & Resolução & Cobertura & $\begin{array}{c}\text { Identidade } \\
\text { Sequencial }\end{array}$ \\
\hline MODELLER* & CDK2 & $1 \mathrm{gz} 8$ & $1,3 \AA$ & $97 \%$ & $44,78 \%$ \\
\hline MODELLER* & CDK7 & $1 \mathrm{ua} 2$ & $3,02 \AA$ & $96 \%$ & $40,94 \%$ \\
\hline BLAST** & CDK2 & $5 \mathrm{oo} 1$ & $2 \AA$ & $97 \%$ & $45,30 \%$ \\
\hline BLAST & CDK5 & $4 \mathrm{au} 8$ & $1,9 \AA$ & $96 \%$ & $44,55 \%$ \\
\hline BLAST & CDK6 & 3 nup & $2,6 \AA$ & $96 \%$ & $40,20 \%$ \\
\hline
\end{tabular}

* Únicas CDKs encontradas no MODELLER sem ciclina. ** CDK de maior identidade sequencial com a CDK11 $\Delta$ encontrada no BLAST

Fonte: Autoria própria.

Já a segunda modelagem foi feita considerando a alta quantidade de estruturas de CDKs 2 encontradas no BLAST com alta resolução e identidade sequencial. As principais características dos moldes utilizados estão na tabela 11 e essa modelagem foi denominada "MODELLER com várias CDKs 2 e uma CDK7”, a CDK7 foi incluída por estar em complexo com ATP. 
Tabela 11 - Principais características dos moldes utilizados na modelagem denominada "MODELLER com várias CDKs 2 e uma CDK7"

\begin{tabular}{|c|c|c|c|c|c|}
\hline $\begin{array}{c}\text { Programa } \\
\text { utilizado para } \\
\text { definir molde }\end{array}$ & Proteína & $\begin{array}{c}\text { Código } \\
\text { PDB }\end{array}$ & Resolução & Cobertura & $\begin{array}{c}\text { Identidade } \\
\text { Sequencial }\end{array}$ \\
\hline MODELLER* & CDK2 & $1 \mathrm{gz} 8$ & $1,3 \AA$ & $97 \%$ & $44,78 \%$ \\
\hline MODELLER* & CDK7 & 1 ua2 & $3,02 \AA$ & $96 \%$ & $40,94 \%$ \\
\hline BLAST** & CDK2 & 5001 & $2 \AA$ & $97 \%$ & $45,30 \%$ \\
\hline BLAST & CDK2 & $3 \mathrm{ezr}$ & $2 \AA$ & $97 \%$ & $45,03 \%$ \\
\hline BLAST & CDK2 & 1 gii & $1,9 \AA$ & $97 \%$ & $44,97 \%$ \\
\hline BLAST & CDK2 & 5000 & $2 \AA$ & $97 \%$ & $45,12 \%$ \\
\hline BLAST & CDK2 & $5 \mathrm{k} 4 \mathrm{j}$ & $1,6 \AA$ & $97 \%$ & $44,63 \%$ \\
\hline
\end{tabular}

* Únicas CDKs encontradas no MODELLER sem ciclina. ** CDK de maior identidade sequencial com a CDK11 $\Delta$ encontrada no BLAST

Fonte: Autoria própria.

Com a finalidade de comparar os modelos gerados, utilizando o método DOPE (Discrete Optimized Protein Energy), foi gerado um perfil de energia resíduo-porresíduo para ambos os modelos (Figura 49) considerando o modelo de menor energia de cada método.

Figura 49 - Perfil de energia resíduo-por-resíduo para os modelos gerados no MODELLER

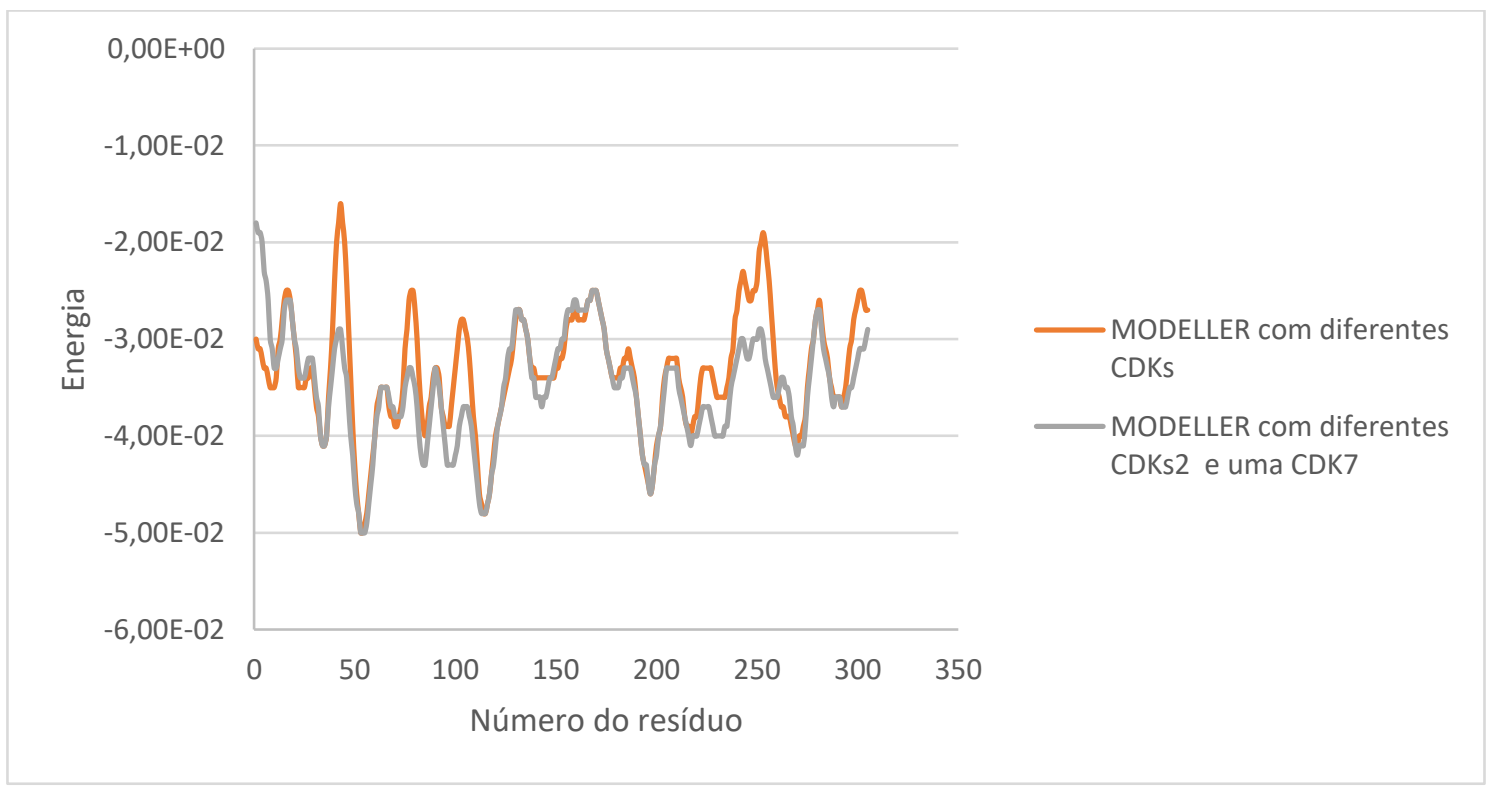

Fonte: Autoria própria. 
Avaliando os modelos finais gerados optou-se por aquele de menor energia que de acordo com a Figura 49, no caso, foi o da modelagem denominada "MODELLER com diferentes CDKs 2 e uma CDK7".

\subsubsection{Inserção dos ligantes por modelagem molecular e análise das interações}

\subsubsection{ATP}

Após escolha do modelo de menor energia foi feita a pesquisa refinada de CDKs contendo seu ligante natural ATP no PDB. Essa pesquisa encontrou seis estruturas: 3blq, 2cjm, 1ua2, 1qmz, 1fin e 1jst. Dentre essas apenas a 1ua2 não possuía a ciclina, porém essa estrutura possui uma baixa resolução $(3,02 \AA)$.

Nesse contexto, analisou-se as outras estruturas quantos as informações estruturais relevantes para a inserção do ligante e escolheu-se a estrutura de código PDB $1 q m z$, que possuía a melhor resolução (2,2 A) e ainda continha o cofator $\mathrm{Mg}^{2+}$, essencial para a atividade da proteína.

É importante ressaltar que apesar dessa estrutura possuir ciclina, ela foi escolhida apenas para inserção do ATP, não influenciando de modo significativo na modelagem da estrutura da proteína que foi feita utilizando múltiplos moldes, todos sem ciclina.

Após inserção do ligante ATP, do cofator $\mathrm{Mg}^{2+}$ e de águas que analisamos como importantes no sítio ativo para a ligação do ATP e do $\mathrm{Mg}^{2+}$ (moléculas de água do arquivo PDB 1qmz números: 2008, 2073, 2094, 2113 e 2201 a 2206), analisou-se os dez modelos de menor energia no SAVES 5.0 e o modelo final escolhido pode ser observado na Figura 50. 
Figura 50 - Modelagem molecular da CDK11 $\triangle$ com ATP, $\mathrm{Mg}^{2+}$ e as moléculas de água de interação.

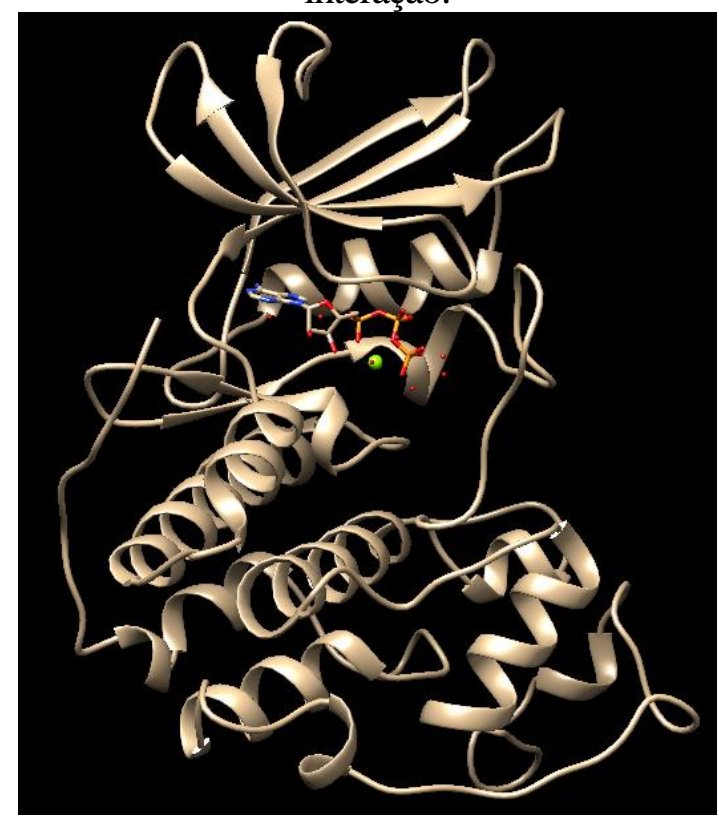

Fonte: Autoria própria.

Esse modelo foi escolhido com base em sua análise no PROCHECK que mostrou todos os aminoácidos em regiões permitidas segundo o gráfico de Ramachandran (Figura 51), exceto pela valina 5.

Figura 51 - Gráfico do Ramachandran para o modelo escolhido da CDK11 $\Delta$ com ATP

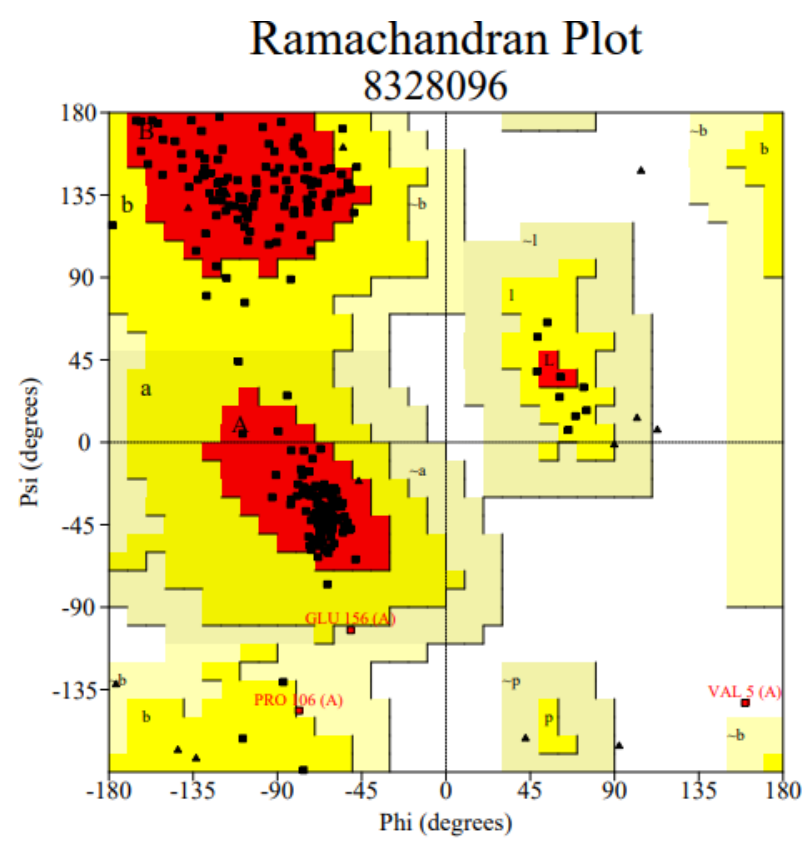

Fonte: Autoria própria. 
Analisando no Chimera observou-se que a valina 5 está em uma região flexível e sem interferência de cadeias laterais de outros aminoácidos o que nos permitiu confiar no modelo gerado.

Em seguida o modelo escolhido foi validado pelos outros programas do SAVES 5.0. e foi feita uma análise utilizando o programa autodocktools para calcular o $\mathrm{K}_{\mathrm{i}}$ teórico da ligação com o ATP, o Mg e as águas foram fixadas com a proteína modelada e foi feito o redocking para o ATP que gerou valores de $\mathrm{K}_{\mathrm{i}}$ em torno de $8 \mu \mathrm{M}$, cuja ordem de grandeza está próximo ao valor obtido para o $\mathrm{K}_{\mathrm{d}}$ experimentalmente, de $4 \mu \mathrm{M}$.

Por dinâmica molecular, utilizando o programa AMBER, avaliou-se a energia do sistema, as principais interações entre a proteína e o ligante e a flexibilidade do sistema.

Os cálculos de energia, utilizando o AMBER ENERGY, mostrou uma energia total de $-914 \mathrm{kcal} / \mathrm{mol}$ e mostrou interações polares fortes predominantes em relação as forças de van der waals, conforme Figura 52.

Figura 52 - Gráfico de energia das interações da CDK11 $\Delta$ com ATP durante a dinâmica.

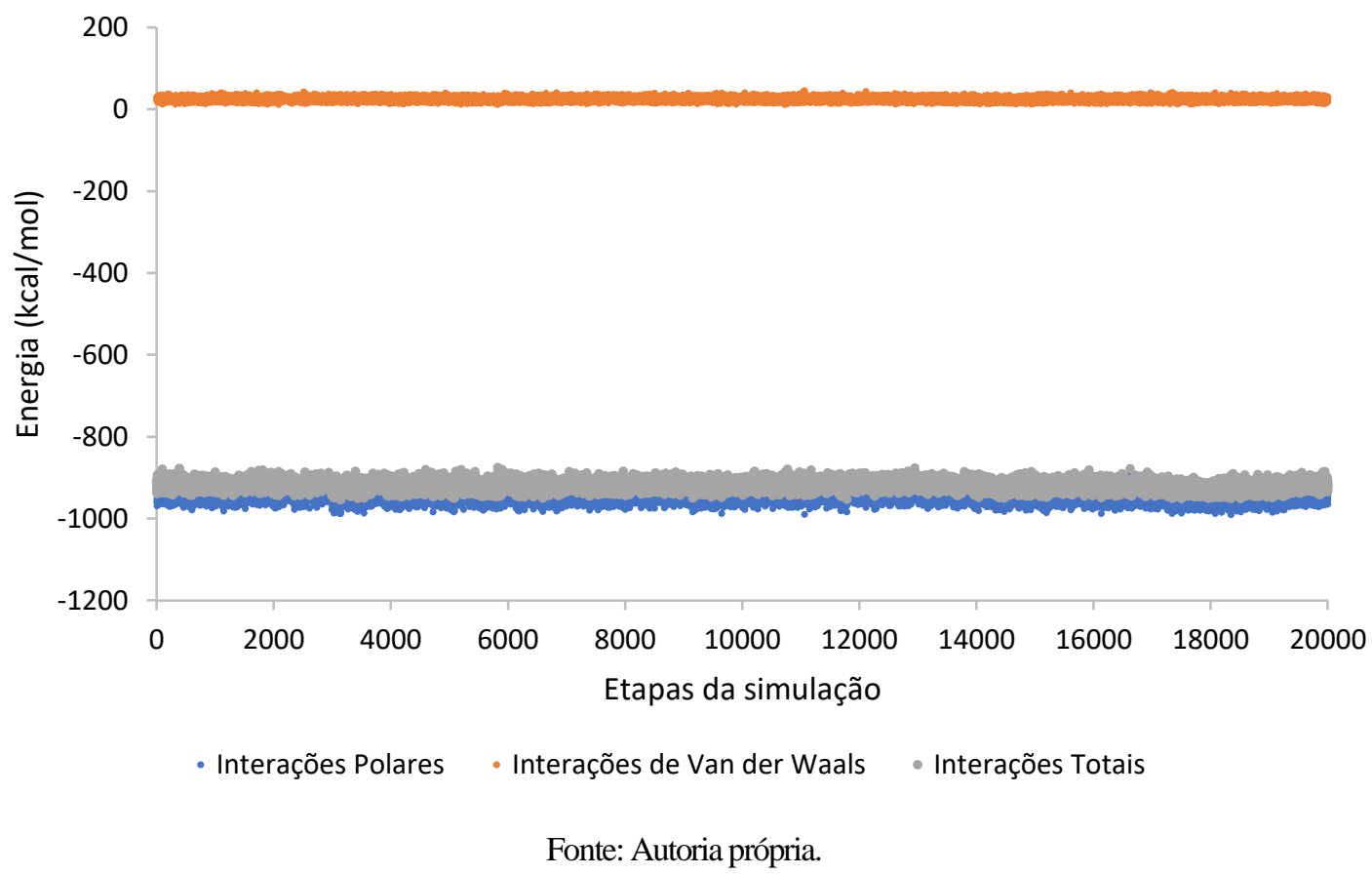

Observou-se que os principais resíduos de aminoácido que interagiam com o ligante ATP foram: Lys 134, Lys37, Thr18 e Asn137, conforme Figura 53. 
Figura 53 - Gráfico de energia das interações dos principais resíduos de aminoácidos da CDK11 $1 \Delta$ com ATP durante a dinâmica.

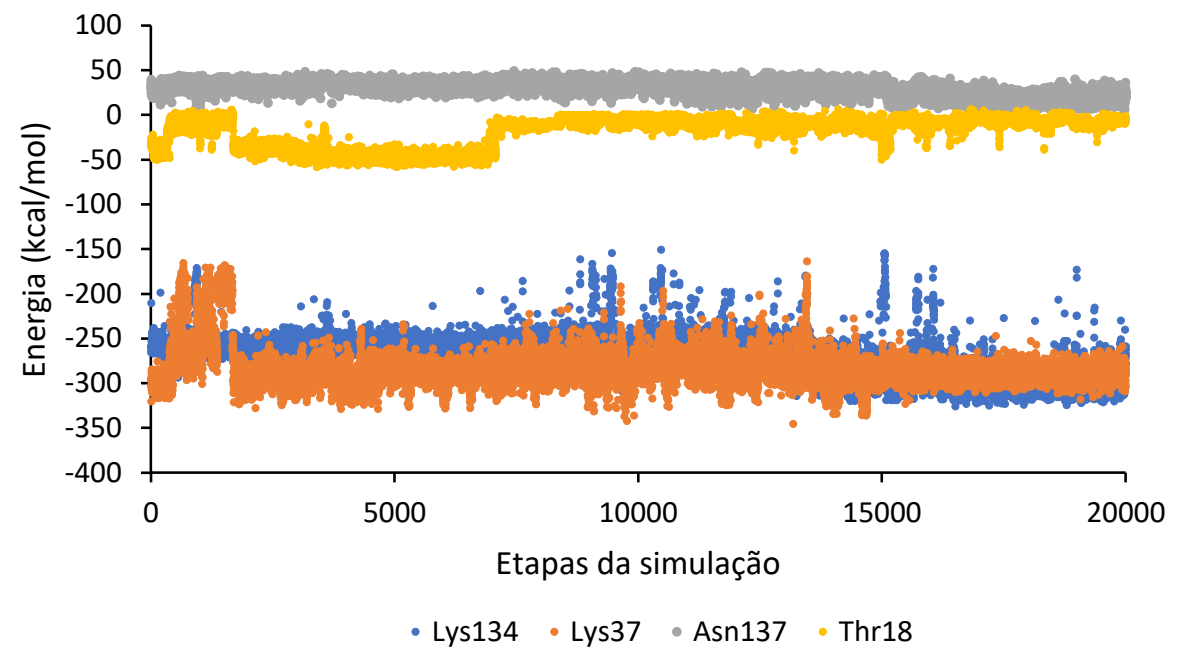

Fonte: Autoria própria.

Conforme pode ser observado (Figura 54) a interação dos resíduos de Lys134 e Lys37 tiveram altas contribuições energéticas favoráveis, em torno de -250 e -300 Kcal / mol. Enquanto a contribuição de Thr18 está em torno de -30 kcal / mol, o resíduo Asn137 teve contribuições levemente desfavoráveis, devido ao programa não ter considerado o íon $\mathrm{Mg}^{2+}$ no cálculo da energia. Além das principais interações energéticas por dinâmica foi possível observar a flexibilidade do sistema proteína-ligante ao longo dos $200 \mathrm{~ns}$ de simulação (Figura 55).

Figura 54 - Interações do ATP com as cadeias laterais dos resíduos de aminoácidos Lys37 e Lys 134 da CDK11.

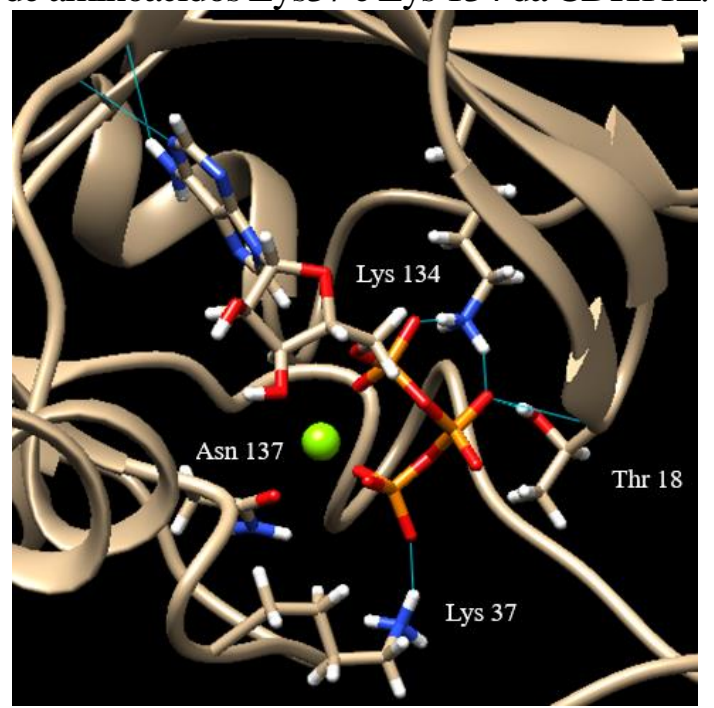

Fonte: Autoria própria. 
Figura 55 - Flexibilidade do sistema proteína-ligante ao longo dos 200ns de simulação. Amarelo (Frame 1) Pink (Frame 7500) Azul (Frame 10000) Rosa claro (Frame 12500)

Verde (Frame 15000) Laranja (Frame 20000).

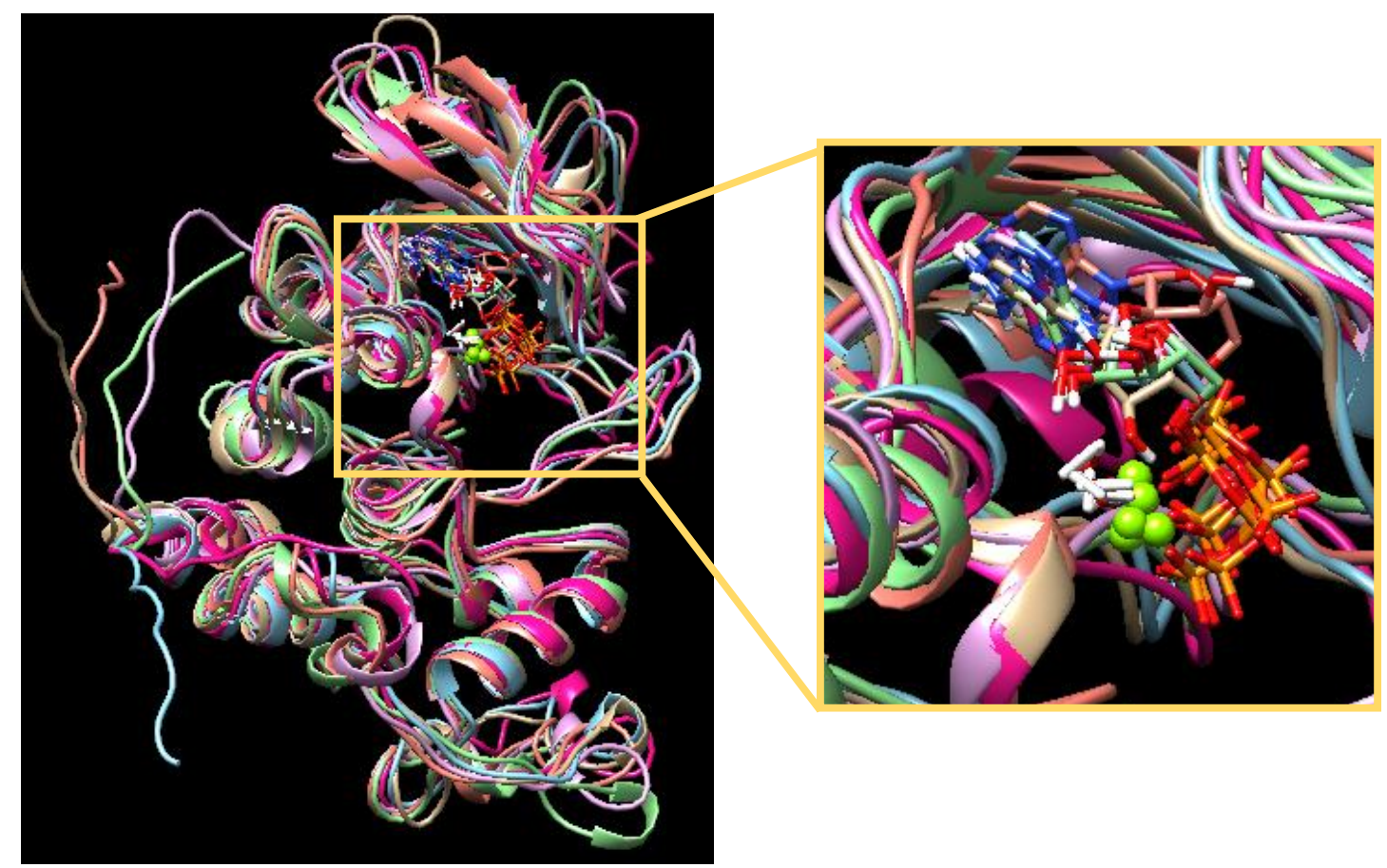

Fonte: Autoria própria.

A Figuras 56 e 57, mostram, respectivamente, apenas o ligante e apenas a proteína ao longo dos 200 ns de simulação.

Figura 56 - Flexibilidade do ligante ao longo dos 200ns de simulação. Amarelo (Frame 1) Pink (Frame 7500) Azul (Frame 10000) Rosa claro (Frame 12500)

Verde (Frame 15000) Laranja (Frame 20000).

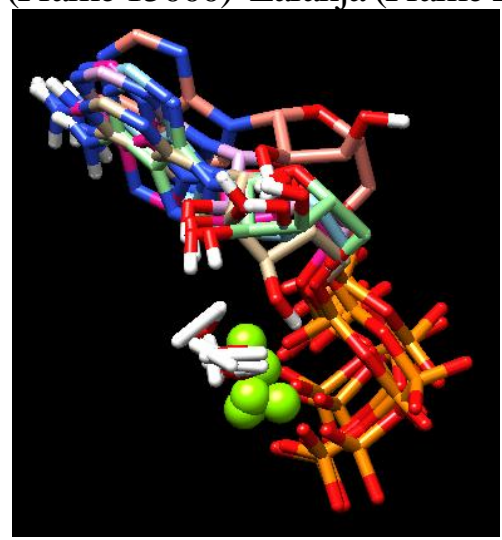

Fonte: Autoria própria. 
Figura 57 - Flexibilidade da proteína ao longo dos 200ns de simulação. Amarelo (Frame 1) Pink (Frame 7500) Azul (Frame 10000) Rosa claro (Frame 12500) Verde (Frame 15000) Laranja (Frame 20000).

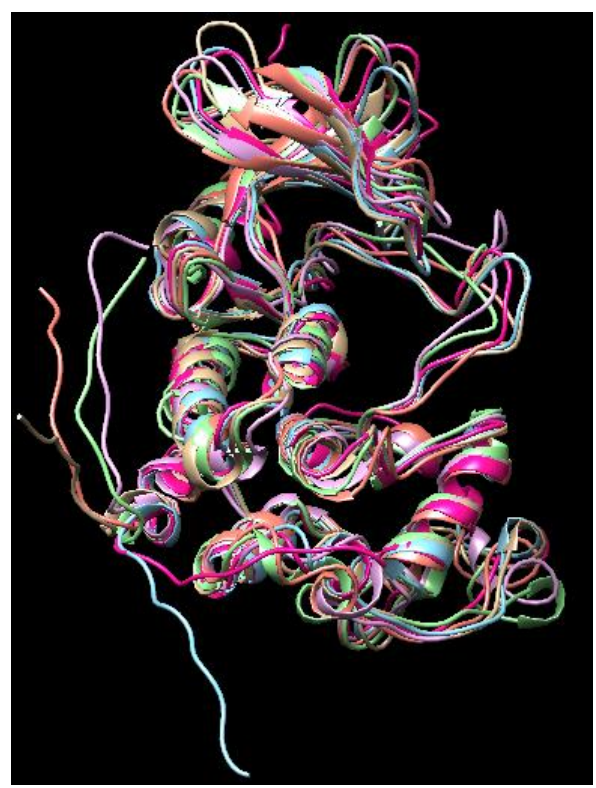

Fonte: Autoria própria.

Levando em conta as principais interações observadas, e com o objetivo de comparar as interações presentes na CDK2 usada como molde (código PDB:1qmz), com as interações obtidas no modelo da CDK11 $\Delta$ com ATP, utilizou-se o programa Chimera para avaliar as principais ligações de hidrogênio presentes, visto que por dinâmica molecular as interações polares foram determinantes para estabilizar energeticamente o sistema.

Inicialmente fez-se uma comparação das ligações de hidrogênio envolvendo o ligante ATP e as cadeias principais dos resíduos de aminoácidos das CDKs.

Na Figura 58A observa-se as interações do ATP com os resíduos de aminoácidos da CDK11 1 , os resíduos envolvidos nessas interações são Asn87, Val89 e Ser136. Já na Figura 58B observa-se as interações do ATP com os resíduos de aminoácidos da CDK2, os resíduos envolvidos nessas interações são Ile10, Glu81, Leu83 e Gln131. 
Figura 58 - Interações do ATP com a cadeia principal dos resíduos de aminoácidos da (A) CDK11 $\Delta$ (B) CDK2

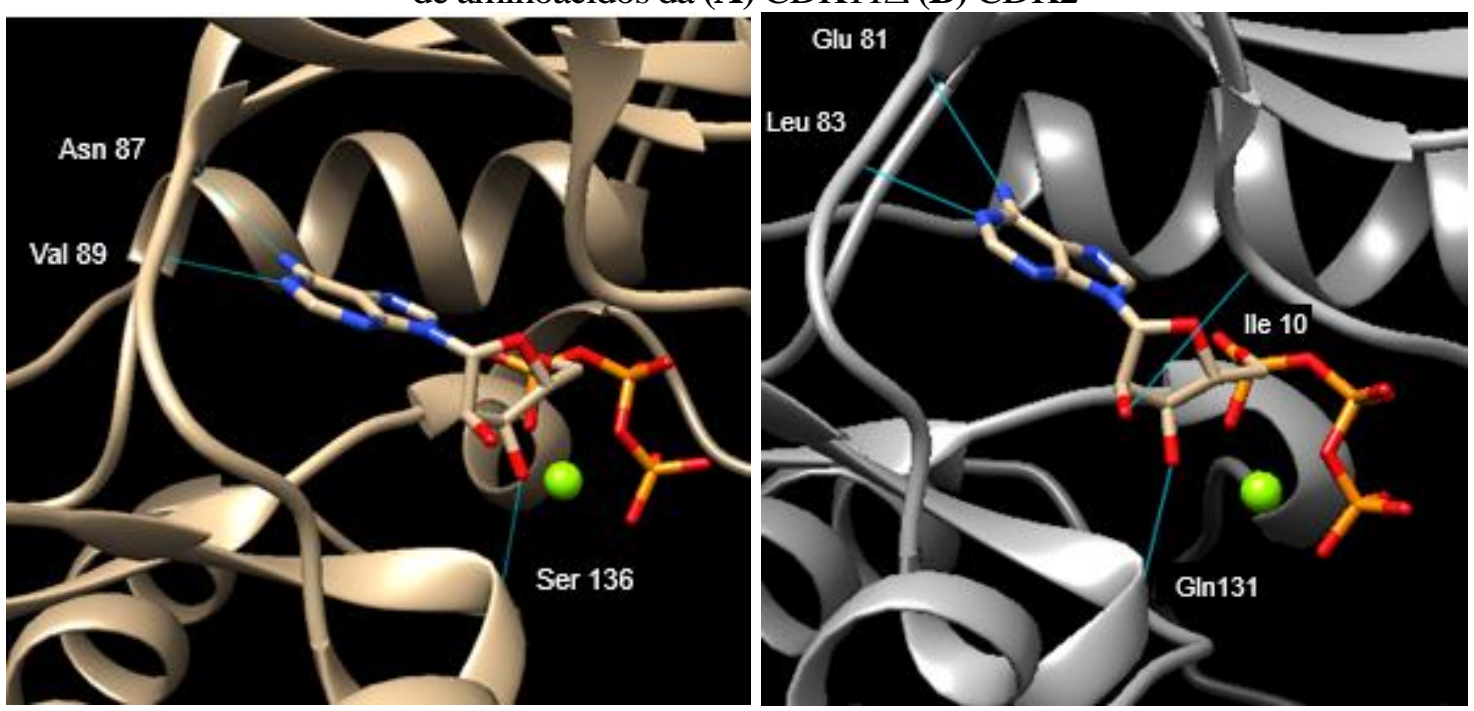

Fonte: Autoria própria.

A região do ATP em que ocorre essas interações e a correspondência desses resíduos de aminoácidos alinhados as proteínas CDK2, podem ser observadas na Tabela 12.

Tabela 12 - Interações do ATP com a cadeia principal dos resíduos de aminoácidos das CDKs 2 e 11.

\begin{tabular}{|c|c|c|c|}
\hline $\begin{array}{c}\text { Resíduo de } \\
\text { aminoácido da } \\
\text { CDK11 }\end{array}$ & $\begin{array}{c}\text { Interação } \\
\text { com ATP }\end{array}$ & $\begin{array}{c}\text { Resíduo de } \\
\text { aminoácido da } \\
\text { CDK2 }\end{array}$ & $\begin{array}{c}\text { Interação } \\
\text { com ATP }\end{array}$ \\
\hline- & - & Ile10 & Ribose \\
\hline Asn 87 & Adenina & Glu81 & Adenina \\
\hline Val89 & Adenina & Leu83 & Adenina \\
\hline Ser 136 & Ribose & Gln131 & Ribose \\
\hline
\end{tabular}

Fonte: Autoria própria.

Apesar de não haver identidade desses resíduos de aminoácidos, como a interação é com a cadeia principal, há a manutenção das interações (com exceção da Ile10 da CDK2), conforme pode ser visualizado na Figuras 58 e na Tabela 12.

Uma segunda análise foi feita comparando-se as interações de hidrogênio envolvendo o ligante ATP e as cadeias laterais dos resíduos de aminoácidos das CDKs. Pela dinâmica, feita para a CDK11 $\Delta$, observou-se as interações do ATP com os resíduos de aminoácidos Lys134, Lys37, Thr18, Asn137, Asp92 e Glu15. Após alinhamento da CDK2 (código PDB 1qmz) usada como molde para a CDK11 (Figura 59) e análise das 
interações do ATP com a CDK2, observa-se ligações de hidrogênio conservadas nos resíduos Lys129, Lys33, Asn132 e Asp86 (tabela 13).

Um resumo dessas interações, a correspondência desses resíduos nas proteínas CDK2 e CDK11 $\Delta$ e a região de interação com ATP, podem ser observadas na Tabela 13.

Figura 59 - Alinhamento da região que se liga ao ATP da CDK2 e da CDK11 $\triangle$. Destacado em
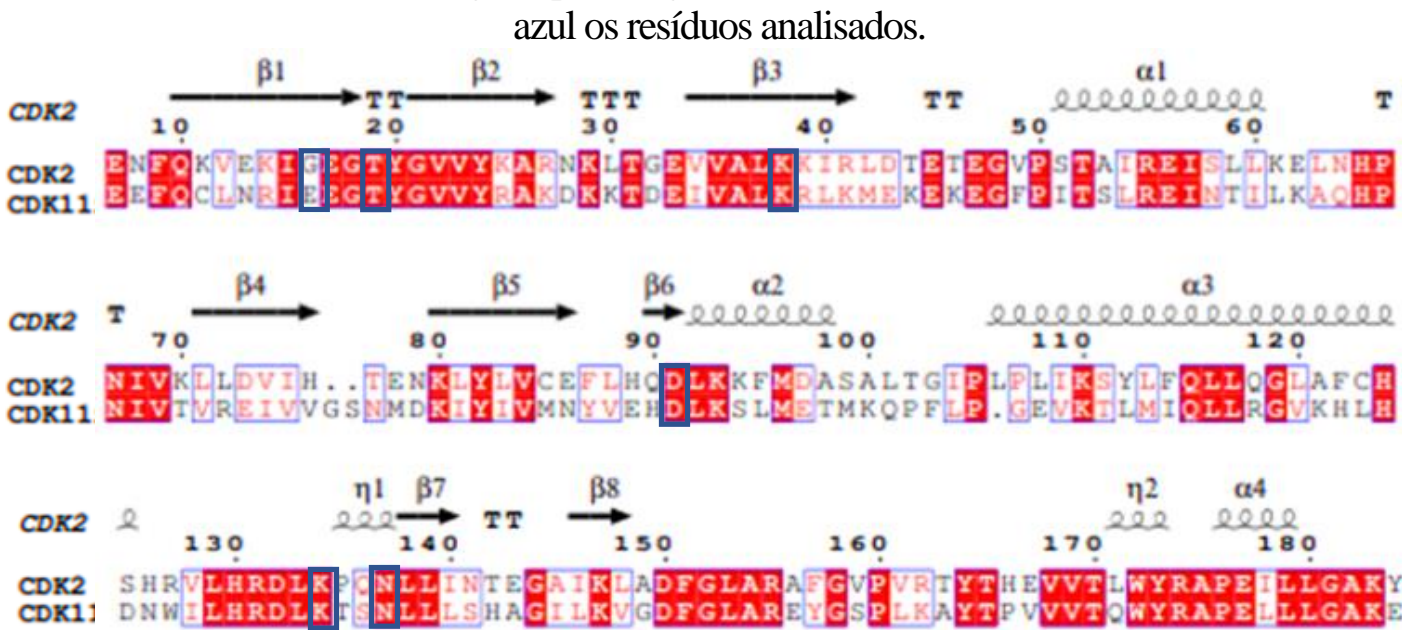

Fonte: Autoria própria.

Tabela 13 - Região de interação com ATP e resíduos de aminoácidos envolvidos nas

CDKs 2 e 11.

\begin{tabular}{|c|c|c|c|c|c|}
\hline $\begin{array}{c}\text { Sigla do } \\
\text { aminoácido } \\
\text { conservado }\end{array}$ & $\begin{array}{c}\text { Resíduo de } \\
\text { aminoácido } \\
\text { da CDK11 }\end{array}$ & $\begin{array}{c}\text { Interação } \\
\text { com ATP }\end{array}$ & $\begin{array}{c}\text { Resíduo de } \\
\text { aminoácido } \\
\text { da CDK2** }\end{array}$ & $\begin{array}{c}\text { Interação } \\
\text { com ATP }\end{array}$ & $\begin{array}{c}\text { Região na } \\
\text { sequência*** }\end{array}$ \\
\hline $\mathrm{K}$ & Lys134 & $\gamma$-fosfato & Lys129 & $\gamma$-fosfato & $\underline{\text { KxxNLLx }}$ \\
\hline $\mathrm{K}$ & Lys37 & $\beta$-fosfato & Lys33 & $\beta$-fosfato & VAL $\underline{\text { }}$ \\
\hline $\mathrm{T}$ & Thr18 & $\beta$-fosfato* & Thr14 & - & GTY \\
\hline $\mathrm{N}$ & Asn137 & $\gamma$-fosfato & Asn132 & $\gamma$-fosfato & $\underline{\text { NLL }}$ \\
\hline $\mathrm{D}$ & Asp92 & Ribose* & Asp86 & Ribose & $\underline{\text { DLK }}$ \\
\hline- & Glu15 & Ribose & Gly11 & - & I $\underline{\text { E }}$ \\
\hline
\end{tabular}

* interação observada após dinâmica molecular **CDK2 de código PDB 1qmz *** o aminoácido envolvido está sublinhado e x representa que o resíduo de aminoácido não é conservado no alinhamento

Fonte: Autoria própria.

As principais ligações de hidrogênio do ATP com as cadeias laterais dos resíduos de aminoácidos da CDK11 $1 \Delta$ podem ser visualizadas nas Figuras 60 e 61, em que se observa uma ligação de hidrogênio entre Lys37 e o fosfato do ATP e duas ligações de hidrogênio de Glu15 com a ribose do ATP (Figura 60), enquanto Asn137 utiliza a água 
316 e a Lys134 utiliza a água 310 para a interação com o fosfato do ATP (Figura 61). Já Asp92 está próximo da ribose do ATP e Thr18 próximo ao fosfato do ATP (Figura 61), mas eles não mostram interação no modelo gerado antes da dinâmica, provavelmente a flexibilidade da proteína seja responsável pela interação significativa com esses resíduos de aminoácidos.

Figura 60 - Interações do ATP com a cadeia lateral dos resíduos de aminoácidos Lys37 e Glu15 da CDK11 $1 \Delta$ sem utilizar a molécula de água.

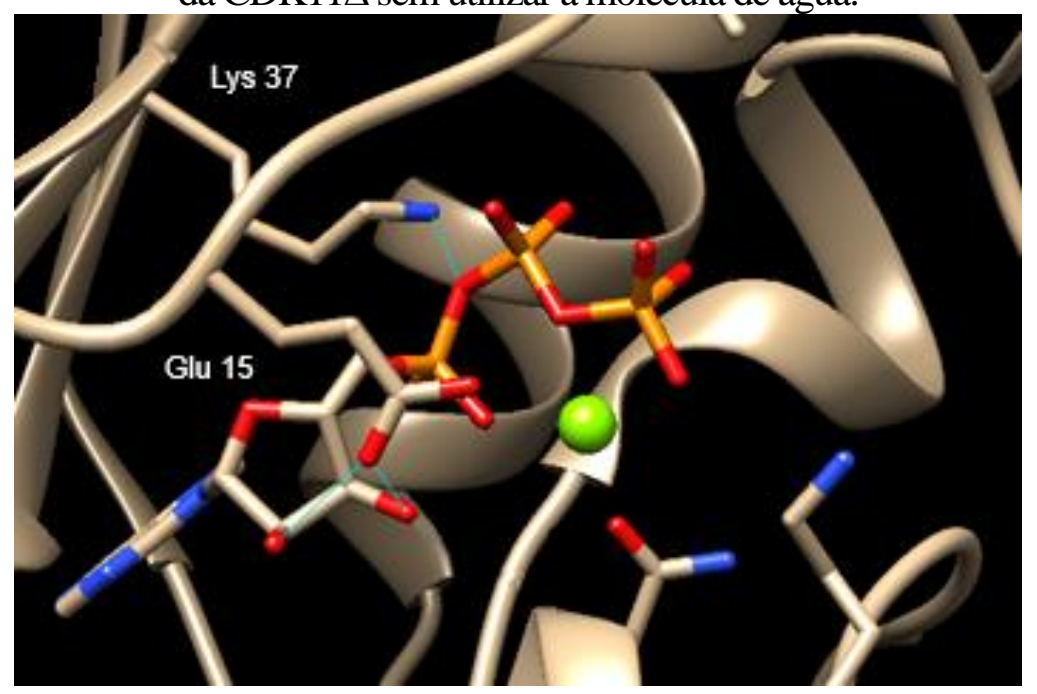

Fonte: Autoria própria.

Figura 61 - Interações do ATP com a cadeia lateral dos resíduos de aminoácidos Asn137 e Lys134 da CDK11 $\Delta$ ligando-se com as águas 310 e 316. Asp92 e Thr18 não mostram interação no modelo gerado, antes da dinâmica.

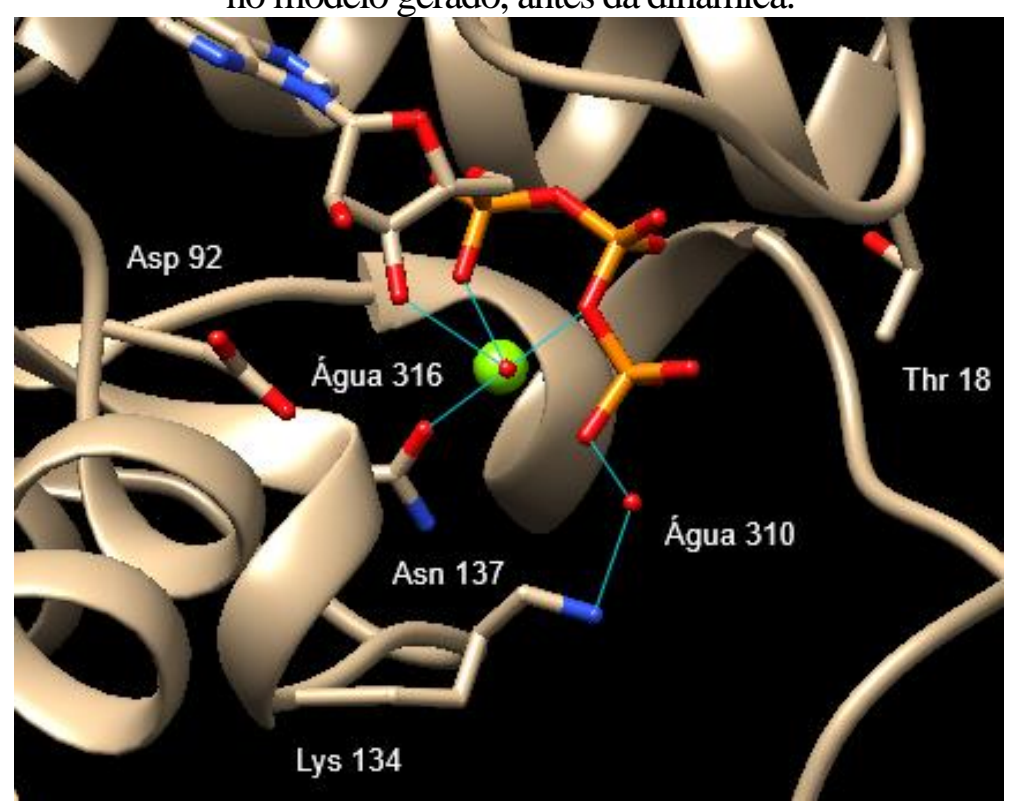

Fonte: Autoria própria. 
Já para a CDK2, as principais ligações de hidrogênio envolvendo a cadeia lateral dos aminoácidos da CDK2 e o ATP podem ser visualizadas nas Figuras 62 e 63, observa-se duas ligações de hidrogênio entre Lys33 e o fosfato do ATP, e Asp86 e a ribose do ATP (Figura 62), enquanto Asn132 utiliza a água 2205 e a Lys129 utiliza a água 2094 para a interação com o fosfato do ATP (Figura 63). Já Thr14 está próximo ao fosfato do ATP, mas não mostra interação de hidrogênio (Figura 63).

Figura 62 - Interações do ATP com a cadeia lateral dos resíduos de aminoácidos Lys33 e Asp86 da CDK2 sem utilizar a água.

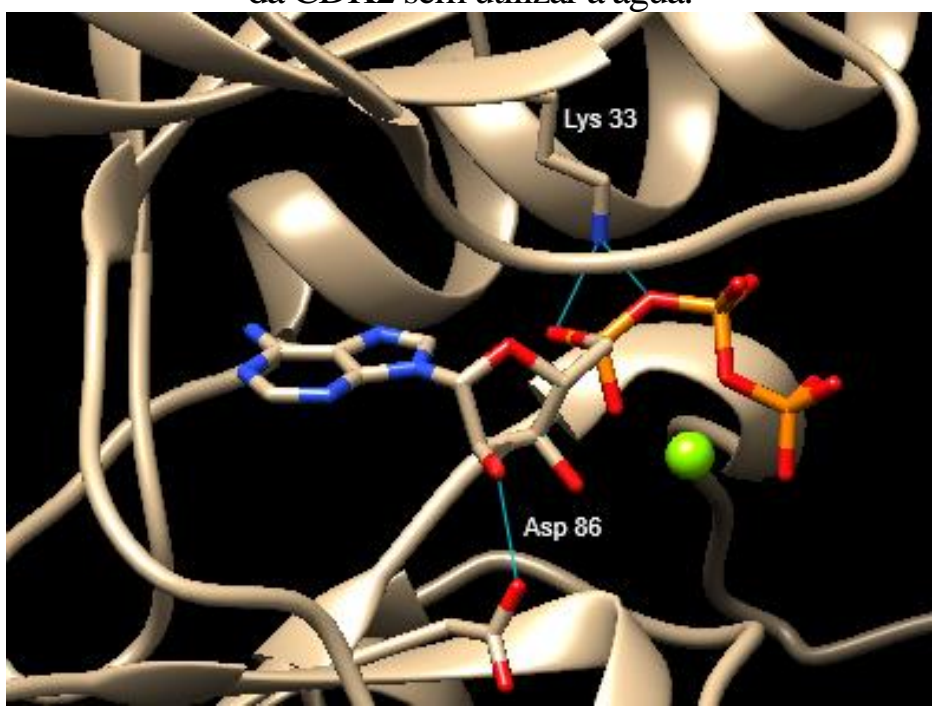

Fonte: Autoria própria.

Figura 63 - Interações do ATP com a cadeia lateral dos resíduos de aminoácidos Asn132 e Lys129 da CDK2 ligando-se com as águas 2205 e 2094. Thr14 não mostra interação de hidrogênio.

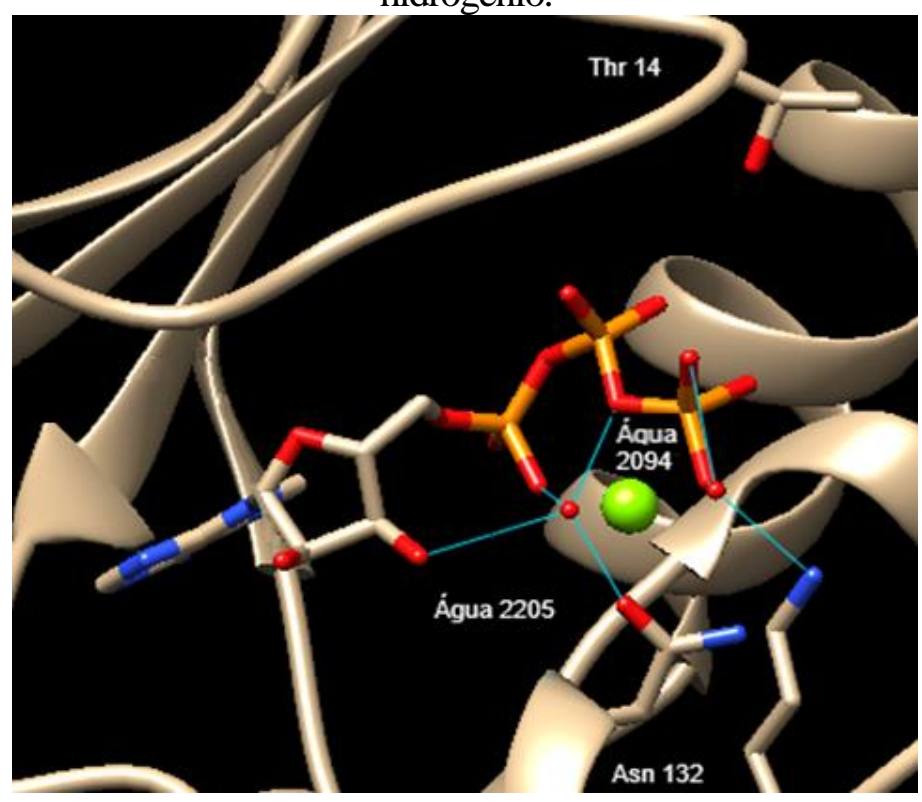

Fonte: Autoria própria. 
Entre as CDKs com estruturas cristalográfica resolvidas, a CDK2 é a mais próxima em similaridade com a CDK11, no entanto filogeneticamente a CDK10 é a que mais se assemelha com a CDK11, mas ela não apresenta estrutura cristalográfica depositada no PDB, diante disso SUN et al. (2005) realizaram a modelagem da CDK10 e observaram os principais aminoácidos envolvidos na interação do ATP com a CDK10.

Após alinhamento da CDK2, CDK10 e CDK11 no programa MultiAlin foi feita a tabela 14 com as interações encontradas nessa modelagem e a correspondência desses resíduos alinhando essas três as proteínas CDK2 e CDK11 representada a região do ATP em que ocorre essas interações com a proteína.

Tabela 14 - Região de interação com ATP e resíduos de aminoácidos envolvidos nas

CDKs 2,11 e 10.

\begin{tabular}{|c|c|c|c|c|c|c|}
\hline $\begin{array}{c}\text { Sigla do } \\
\text { aminoácido } \\
\text { conservado }\end{array}$ & $\begin{array}{c}\text { Resíduo de } \\
\text { aminoácido } \\
\text { da CDK11 }\end{array}$ & $\begin{array}{c}\text { Interação } \\
\text { com ATP }\end{array}$ & $\begin{array}{c}\text { Resíduo de } \\
\text { aminoácido } \\
\text { da CDK2** }\end{array}$ & $\begin{array}{c}\text { Interação } \\
\text { com ATP }\end{array}$ & $\begin{array}{c}\text { CDK10 } \\
* * *\end{array}$ & $\begin{array}{c}\text { Interação } \\
\text { com ATP }\end{array}$ \\
\hline $\mathrm{K}$ & Lys134 & $\gamma$-fosfato & Lys129 & $\gamma$-fosfato & Lys136 & - \\
\hline $\mathrm{K}$ & Lys37 & $\beta$-fosfato & Lys33 & $\beta$-fosfato & Lys39 & $\beta$-fosfato \\
\hline $\mathrm{T}$ & Thr18 & $\beta$-fosfato* & Thr14 & - & Thr20 & $\gamma$-fosfato \\
\hline $\mathrm{N}$ & Asn137 & $\gamma$-fosfato & Asn132 & $\gamma$-fosfato & Asn139 & $\gamma$-fosfato \\
\hline $\mathrm{D}$ & Asp92 & Ribose* & Asp86 & Ribose & Asp94 & Ribose \\
\hline- & Glu15 & Ribose & Gly11 & - & Gly17 & - \\
\hline
\end{tabular}

* interação observada após dinâmica molecular **CDK2 de código PDB 1qmz *** SUN et al. (2005)

Fonte: Autoria própria.

\subsubsection{Roscovitina}

Após escolha do modelo de menor energia para a CDK11 $\Delta$, foi realizada uma pesquisa no PDB, em busca de uma estrutura de CDK2 sem a ciclina associada, mas contendo a roscovitina. Foi encontrada a estrutura a 2,4 $\AA$ de resolução (estrutura de código PDB 2a41), a qual foi escolhida ter maior similaridade sequencial com a CDK11.

Após inserção do ligante Roscovitina, pelo programa MODELLER, analisou-se os dez modelos de menor energia no SAVES 5.0. e o modelo final escolhido pode ser observado na Figura 64. 
Figura 64 - Modelagem molecular da CDK11 $\Delta$ com roscovitina

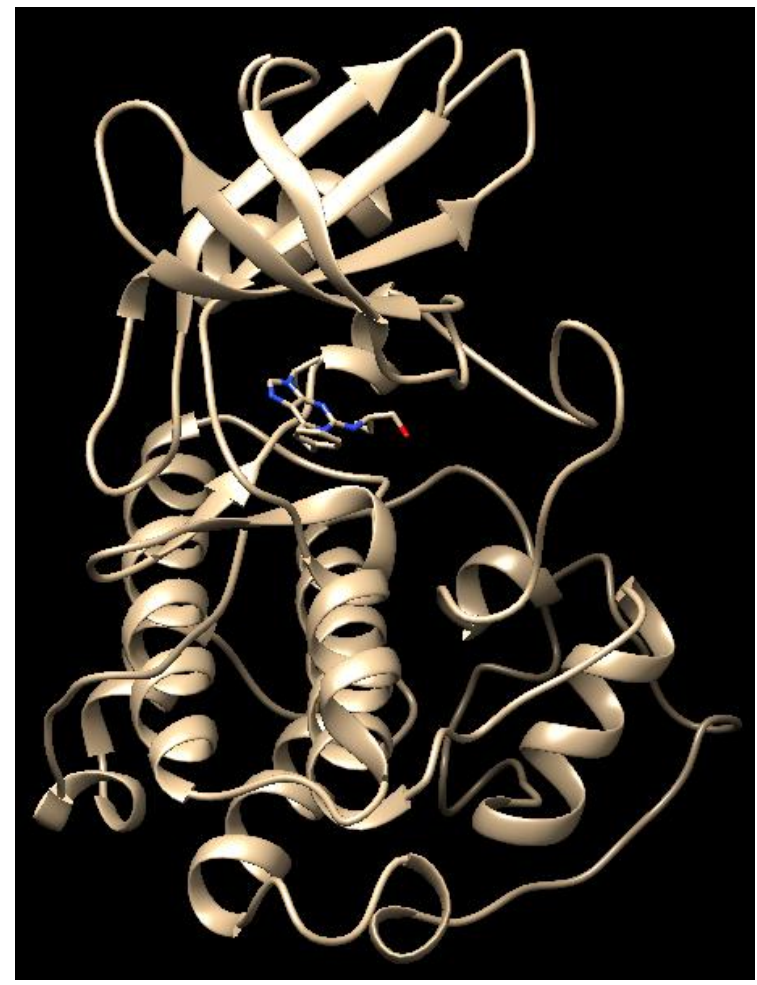

Fonte: Autoria própria.

Esse modelo foi escolhido com base em sua análise no PROCHECK cujo resultado mostrou todos os aminoácidos em regiões permitidas, exceto a valina 5 (resultado similar ao encontrado para o ATP) que ao ser analisada no Chimera, mostrou estar em uma região flexível e sem interferência de cadeias laterais de outros aminoácidos, o que nos permitiu confiar no modelo gerado.

Em seguida o modelo escolhido foi validado pelos outros programas do SAVES 5.0 e as principais interações avaliadas no Chimera e no Pymol.

No Chimera foram analisadas as interações de hidrogênio. Na estrutura de código 2a41 do PDB, a roscovitina interage com a CDK2 na cadeia principal dos resíduos de aminoácido Leu83 e His84 (Figura 65). 
Figura 65 - Interações da Roscovitina com a cadeia principal dos resíduos de aminoácidos da CDK2

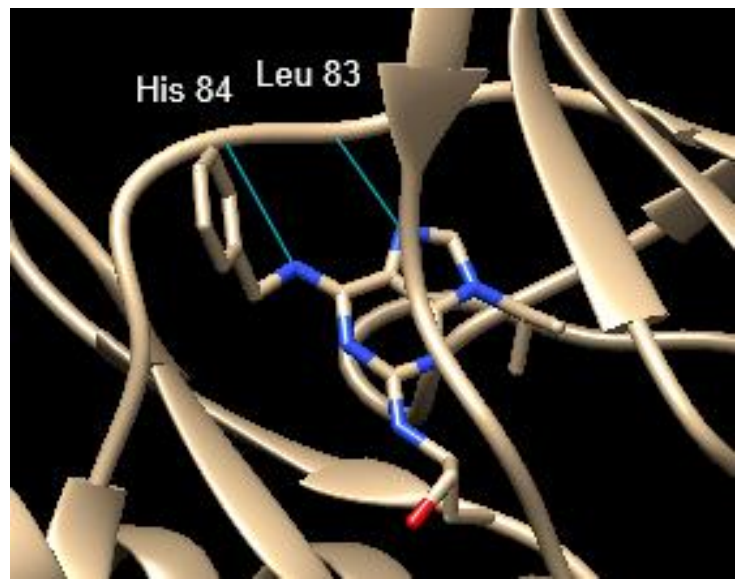

Fonte: Autoria própria.

E no modelo gerado da CDK11 $\Delta$ interage com Val89 e Glu90 (Figura 66).

Figura 66 - Interações da Roscovitina com a cadeia principal dos resíduos de aminoácidos da CDK11s

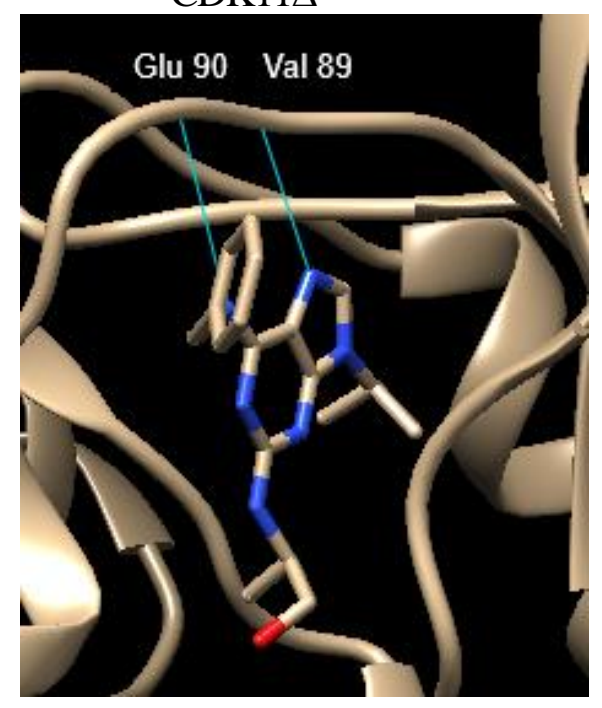

Fonte: Autoria própria.

Conforme já bem caracterizado na literatura, a roscovitina se liga no bolsão de ligação ao ATP e ao sobrepor a estrutura da CDK2 com o ATP (código PDB 1qmz) com a estrutura da CDK2 com roscovitina (código PDB 2a4l), observa-se que o anel de purina do ATP e da roscovitina ocupam aproximadamente a mesma região, enquanto o anel benzílico da roscovitina aponta para o exterior do bolsão e ocupa uma região, não ocupada por nenhuma parte do ATP (Figura 67). 
Figura 67 - Sobreposição da estrutura da CDK2 (cinza) com o ATP (amarelo) (código PDB 1qmz) com a estrutura da CDK2 (azul) com roscovitina (vermelha). (código PDB 2a4l)

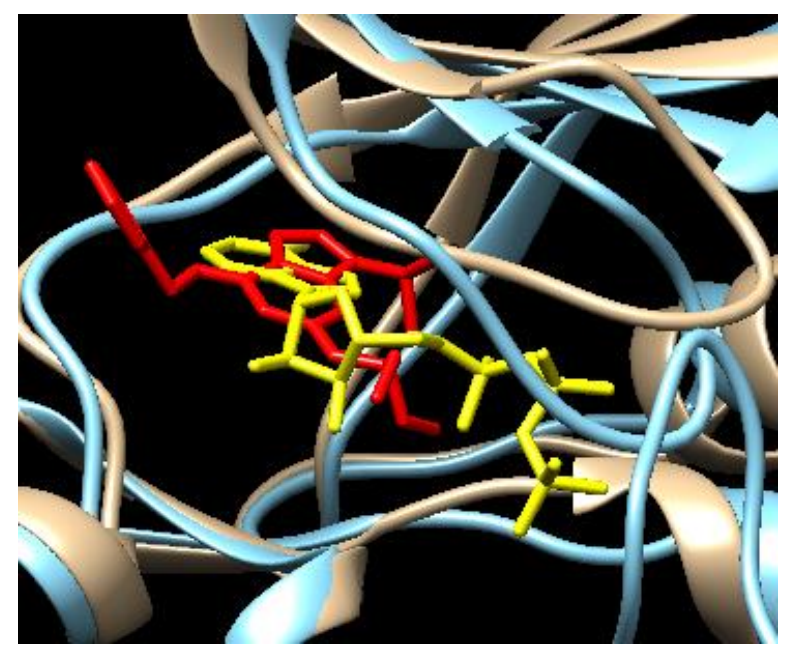

Fonte: Autoria própria.

O mesmo pode ser observado para os modelos da CDK11 $\Delta$ com ATP e com roscovitina (Figura 68).

Figura 68 - Sobreposição do modelo da CDK11 $\Delta$ (cinza) com o ATP (amarelo) com o modelo da CDK11 $\Delta$ (azul) com roscovitina (vermelha).

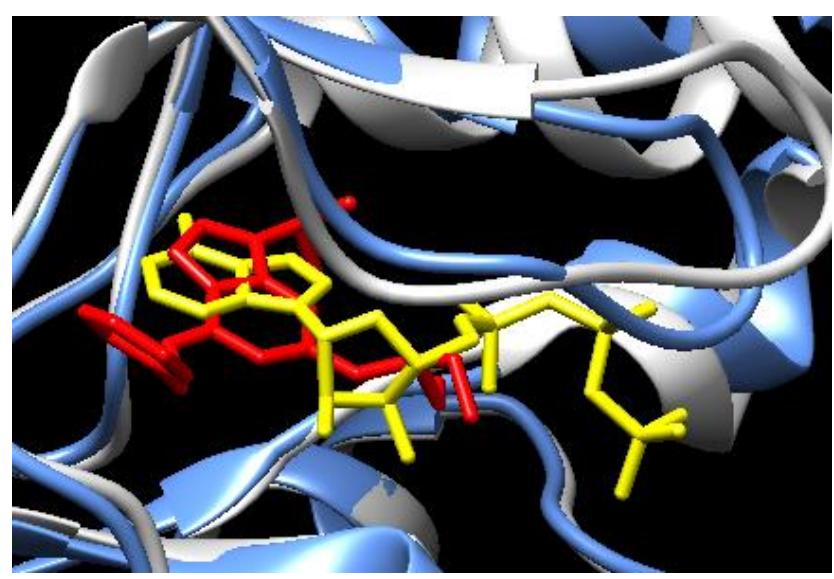

Fonte: Autoria própria.

Conforme relatado por Azevedo et al. (1997) na estrutura de código PDB 2a41 a ligação da roscovitina na CDK2 é caracterizada predominantemente por interações de van der waals e interações hidrofóbicas. A fim de comparar as interações de van der walls da roscovitina com a CDK2 e com o modelo gerado para a CDK11, essas interações foram avaliadas pelo programa pymol e um esquema 2D elaborado a partir dos dados obtidos, podem ser observadas nas Figuras 69 e 70. 
Figura 69 - Principais interações de van der waals da CDK2 com roscovitina (código PDB 2a4l)

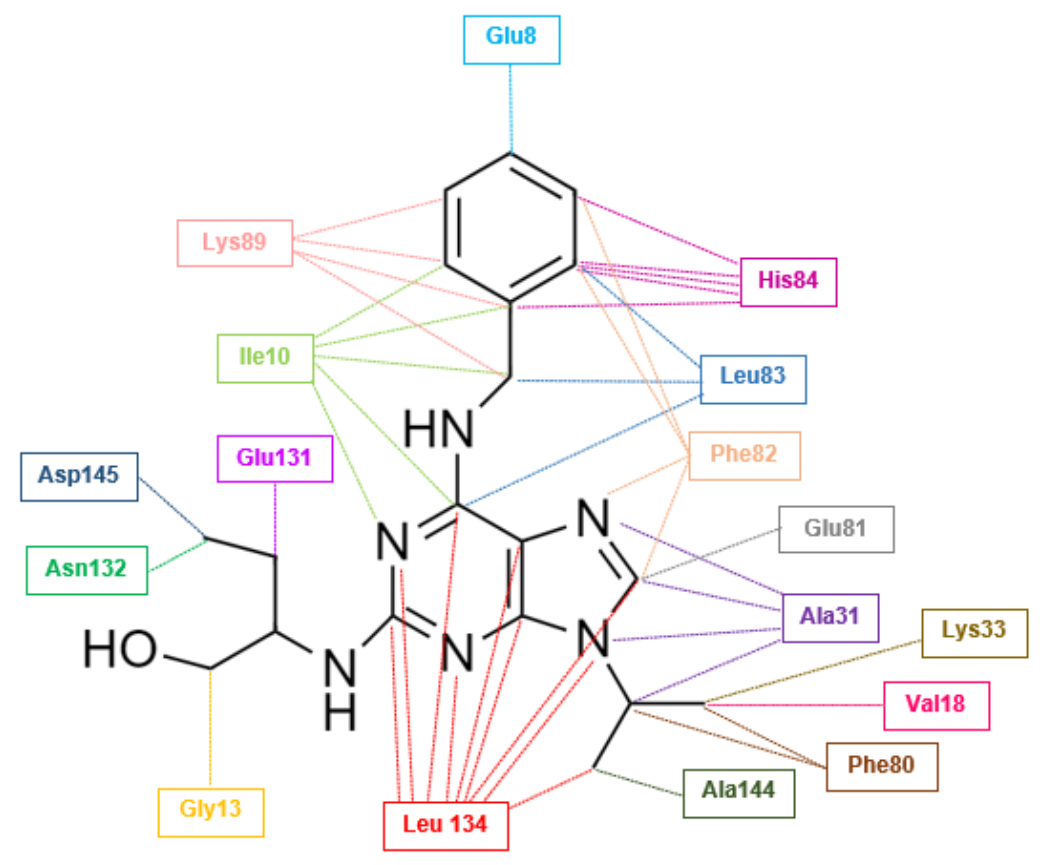

Fonte: modificado de AZEVEDO et al (1997).

Figura 70 - Principais interações de van der waals do modelo gerado da CDK11 $\Delta$ com roscovitina.

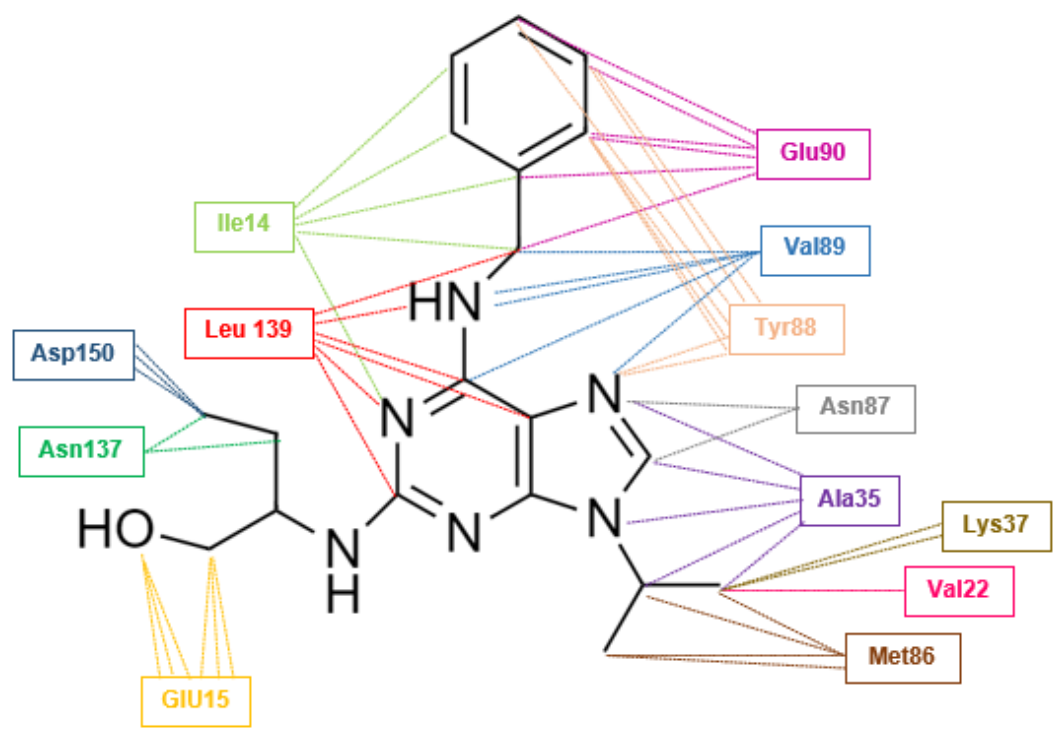

Fonte: Autoria própria.

Considerando apenas os resíduos de aminoácidos, o total de contatos entre roscovitina e CDK2 é de 44 e o total de contatos entre roscovitina e CDK11 $\Delta$ é de 55. Isso mostra que a interação com a CDK11 é similar a interação com a CDK2, sugerindo 
que a roscovitina tem potencial para inibir a CDK11 assim como para inibir a CDK2, o que está de acordo com o observado experimentalmente nos ensaios de fluorimetria, conforme apresentado para a $\mathrm{CDK} 11 \Delta$ na presença da roscovitina.

\subsection{Ensaios de Cristalização}

A obtenção de um cristal de uma proteína é desafiadora, pois, além de ser difícil a obtenção das condições adequadas para o crescimento, os cristais de proteínas são muito frágeis. Outro desafio em nosso estudo foi a falta de um sistema automatizado para testes em grandes quantidades, alcançando uma maior quantidade de condições testadas com uma quantidade menor de proteína.

Em nosso estudo 192 condições foram testadas manualmente utilizando o método da gota suspensa, mas em nenhuma delas obtivemos sucesso. Na solução 36 do kit Crystal Screen HR2-110 cresceram cristais em lâminas finas, mas eles dissolveram após 3 dias e não foram reprodutíveis, apesar de inúmeras tentativas.

\subsection{Estudos dos potenciais inibidores $3 a, 3 b$ e $3 f$ com a CDK11 $\Delta$}

Os potenciais compostos inibidores de CDKs analisados, nomeados, 3a, $3 \mathrm{~b}$ e $3 \mathrm{f}$ possuem uma estrutura similar ao ATP (Figura 71). Os resultados obtidos para a CDK11 $\Delta$ com esses compostos podem ser observados respectivamente nas Figuras 72, 73 e 74.

Figura 71 - 4-aminomethyl-N-arylpyrazoles, em que o R será omitido afim de preservar as informações.

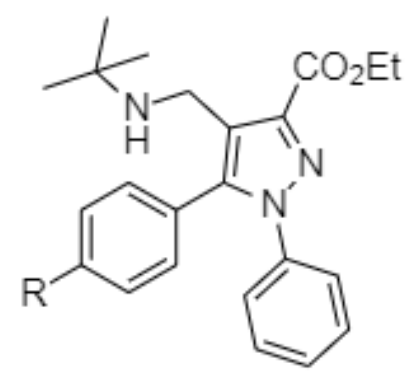

Fonte: Autoria própria. 
Figura 72 - Gráfico $\mathrm{F}_{0} / \mathrm{F}$ versus log [Composto 3a] e ajuste linear para CDK $11 \Delta$ e o composto $3 a$.

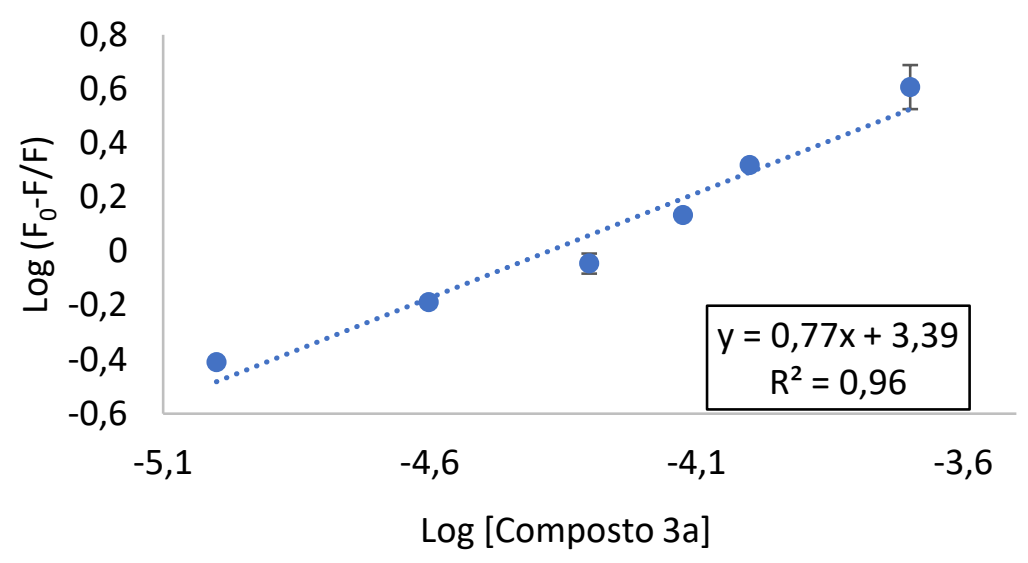

Fonte: Autoria própria.

Figura 73 - Gráfico $F_{0} / F$ versus log [Composto $\left.3 b\right]$ e ajuste linear para CDK $11 \Delta$ e o composto $3 b$.

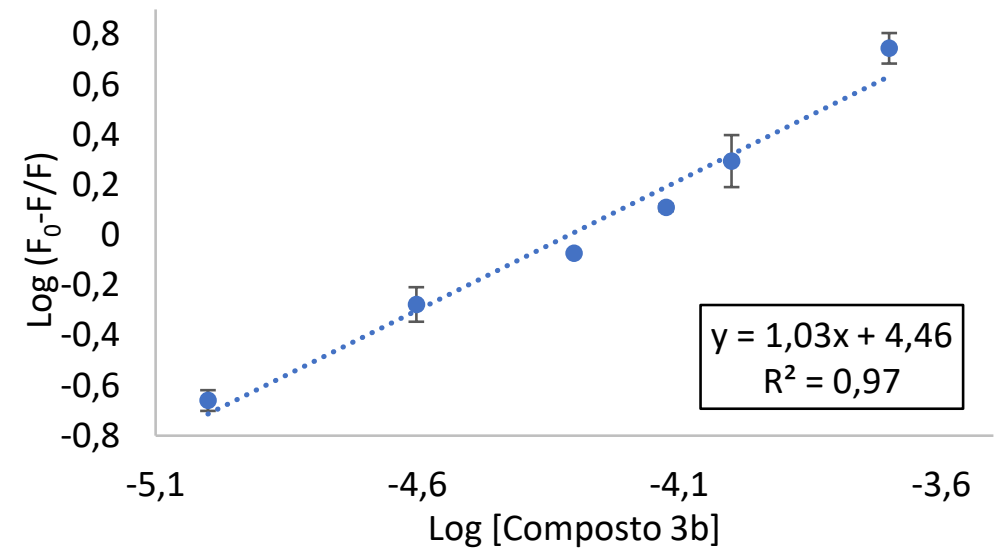

Fonte: Autoria própria.

Figura 74 - Gráfico $F_{0} / F$ versus $\log$ [Composto 3f] e ajuste linear para CDK11 $1 \Delta$ e o composto $3 f$.

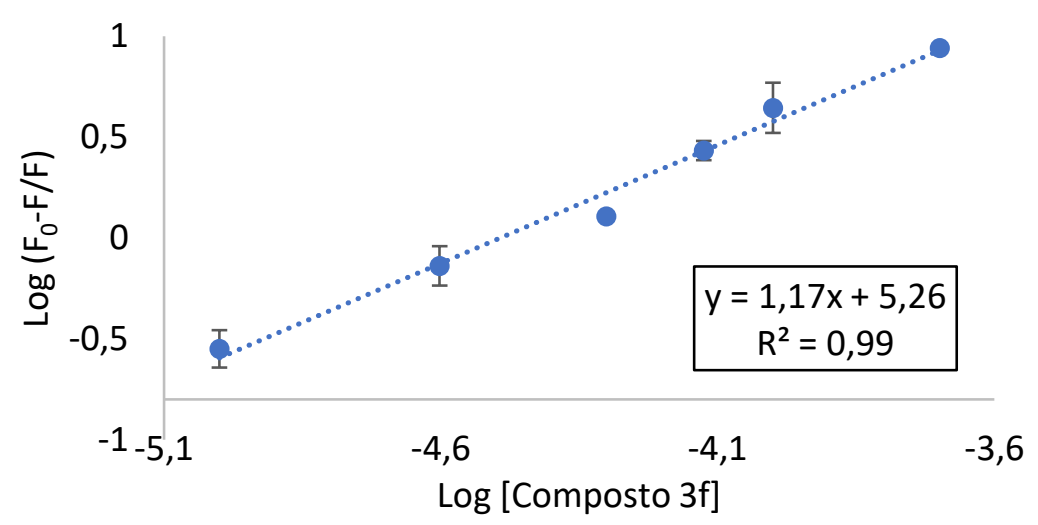

Fonte: Autoria própria. 
Após ajuste linear e utilizando a equação 3, contida no tópico de resultados, obteve-se para CDK11 $\mathrm{n}=0,77$ e $\mathrm{K}_{\mathrm{a}}=2,44.10^{3} \mathrm{M}^{-1}$ com o composto $3 \mathrm{a}, \mathrm{n}=1,03$ e $\mathrm{K}_{\mathrm{a}}=2,89.10^{4} \mathrm{M}^{-1}$ com o composto $3 \mathrm{~b}$ e $\mathrm{n}=1,17$ e $\mathrm{K}_{\mathrm{a}}=1,84.10^{5} \mathrm{M}^{-1}$ com o composto $3 \mathrm{f}$. Analisando os valores obtidos, observa-se que para o composto 3a ocorreu uma interação fraca e para os $3 \mathrm{~b}$ e 3f, observa-se uma interação moderada. Os valores das constantes de dissociação $\left(\mathrm{K}_{\mathrm{d}}\right)$ para CDK11 $1 \Delta$ foram de $409 \mu \mathrm{M}, 35 \mu \mathrm{M}$ e de $5 \mu \mathrm{M}$, para os compostos 3a, $3 \mathrm{~b}$ e $3 \mathrm{f}$, respectivamente.

Quanto aos ensaios celulares, as imagens referentes a cada uma das linhagens testadas podem ser observadas na Figura 75 e os resultados finais obtidos em relação a viabilidade celular frente aos compostos testados podem ser observados na Figura 76.

Figura 75 - Linhagens celulares mantidas em cultivo. (A) Balb/C3T3 (controle); (B) MDA-MB231 e (C) MCF-7.
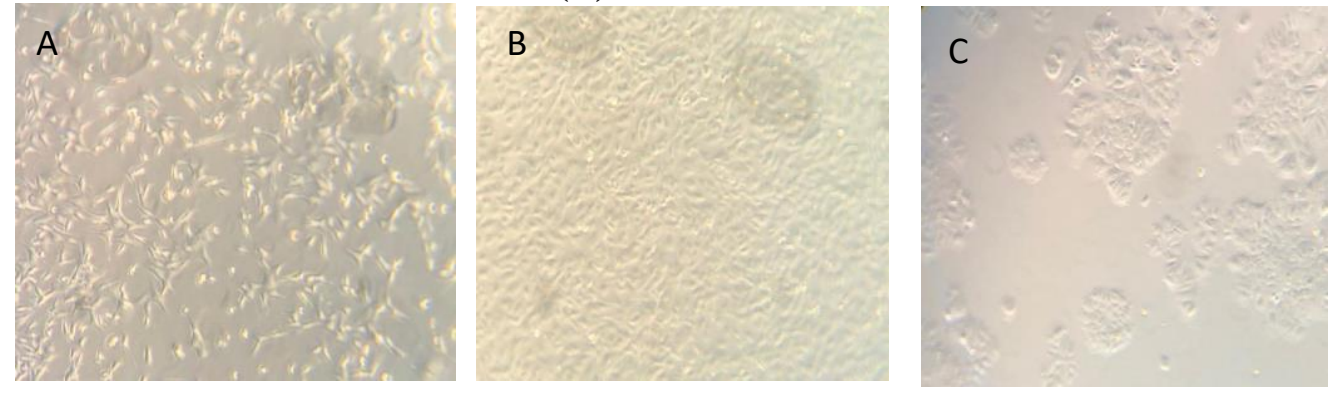

Fonte: Autoria própria.

Figura 76 - Viabilidade de células Balb/C3T3, MDA-MB-231 e MCF-7 após 72h de incubação na presença de diferentes concentrações dos compostos 3a e $3 \mathrm{f}(10 \mu \mathrm{M}, 50 \mu \mathrm{M}$ e $100 \mu \mathrm{M})$ avaliada pelo método colorimétrico MTT

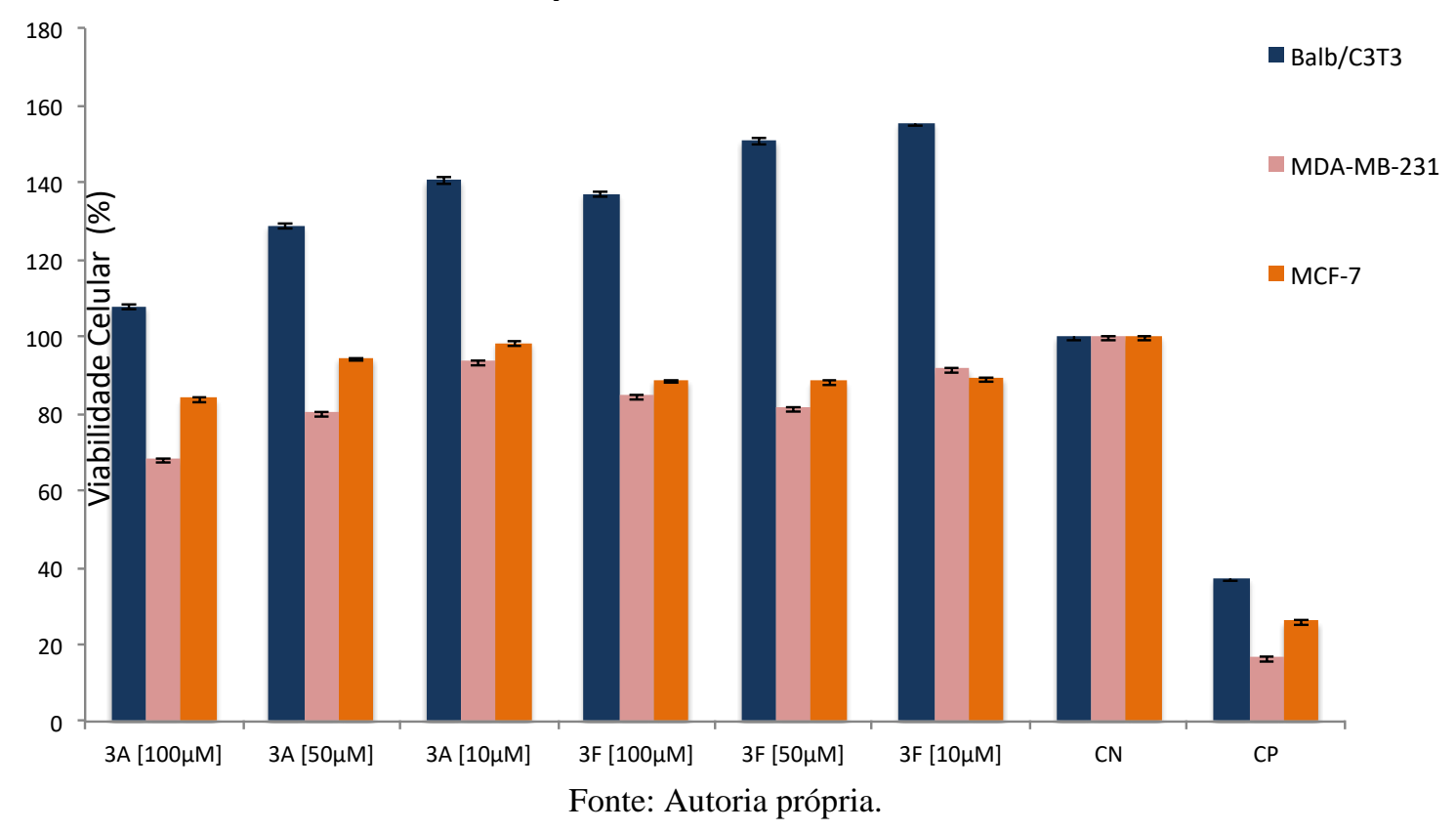


Os resultados obtidos na Figura 76 demonstraram que os compostos $3 \mathrm{a}$ e $3 \mathrm{f}$ não foram citotóxicos para as linhagens MDA-MB-231 e MCF-7. Futuramente serão feitos ensaios para o composto $3 \mathrm{~b}$ e ensaios a fim de verificar a atividade citostática dos compostos $3 \mathrm{a}$, $3 b$ e $3 f$.

\section{CONCLUSÕES}

CDK11 1 foi superexpressa em corpo de inclusões de E. coli e os protocolos de reenovelamento produziram alta concentração de proteína. Esta metodologia tem a vantagem de fornecer a proteína de maneira mais simples quando comparado a expressão em sistemas eucarióticos. É um protocolo que requer apenas uma etapa de purificação após o redobramento, rendendo $30 \mathrm{mg} / \mathrm{L}$ de CDK11 , com $97 \%$ de pureza.

A CDK11 recombinante foi submetida a estudos de caracterização biofísica, que mostraram que a proteína foi reenovelada e interage com seu ligante ATP. Pela primeira vez, a interação entre $\operatorname{CDK} 11 \Delta$ e roscovitina (um inibidor já estudado para outras CDKs) foi demonstrada experimentalmente, cujos resultados indicam este ligante como um inibidor promissor de CDK11. Também foram observadas interações fraca (com o composto 3a) e moderada (com os compostos 3b e 3f) em relação aos potenciais inibidores do projeto com parceria da professora Dra. Fernanda Andreia Rosa.

Análises bioinformáticas do domínio quinase da CDK11 em complexo com ATP e com roscovitina contribuíram para o entendimento do modo de interação entre esses ligantes e o sítio de ligação da enzima. Nesse contexto, a obtenção do domínio quinase da CDK11 é um avanço para a pesquisa acerca das CDKs, e abre-se a possibilidade de expressá-la com suas ciclinas parceiras, o que permitirá estudos de inibição utilizando complexos CDK11-ciclina como alvos. Inclusive, em seu doutorado, a aluna Fernanda Coelho, membro do nosso grupo de pesquisa, demonstrou que a CDK11 $\Delta$ aqui obtida interage com a ciclina D3 e possui atividade. O resultado será publicado em sua tese de doutorado.

A proteína obtida pôde ainda ser usada em ensaios de cristalização, o que abre a possibilidade de determinar a estrutura cristalográfica da CDK11 $\Delta$ na forma nativa e em complexo com ligantes, o que fornecerá informações cruciais para a busca de um inibidor eficaz para CDK11. 
CDK11 $\Delta$ também poderá ser usada para desenvolver anticorpos e kits de detecção, nos quais CDK11 é um biomarcador para terapia direcionada, uma vez que sua superexpressão está associada a vários cânceres.

\section{PARTICIPAÇÃO EM OUTROS PROJETOS}

\subsection{Clonagem da CDK11 $\Delta$ em pETSUMO e testes de expressão.}

Em paralelo ao meu projeto, pude acompanhar uma aluna de iniciação científica, Aline de Oliveira Santos em seu projeto, que objetivou a expressão da mesma CDK11 $\Delta$, a partir do recombinante pETSUMO-CDK11 fração solúvel do lisado bacteriano, já que seria expressa em fusão com a SUMO.

E. coli é um hospedeiro de sucesso para expressão de várias proteínas heterólogas, mas muitas delas não são expressas em sua forma solúvel. O Southeast Collaboratory for Structural Genomics (SECSG) relatou que apenas cerca de 22,7\% são expressas no solúvel, mas o uso de proteínas de fusão são uma alternativa muito utilizada. O efeito da SUMO no aumento da solubilidade é atribuído a sua estrutura, que possui uma superfície hidrofílica externa e um núcleo hidrofóbico interno, o que a faz exercer um efeito comparável ao detergente (BUTT et al., 2005).

Para produção dos primers foram inseridos os sítios de restrição para as enzimas XhoI e EcorI (Figura 77). A análise dos primers foi realizada utilizando o IDTDNA (https://www.idtdna.com/calc/analyzer), considerando suas características quanto a formação de hairpin, temperatura de anelamento e porcentagem de CG.

Figura 77 - Primers desenhados para amplificação do cDNA da CDK11 $\Delta$ em pETSUMO.

Primer direto AATGAATTCGGCTGCCGTAGCGTCGAGG $57,1 \% \mathrm{CG} \quad \mathrm{T}_{\mathrm{m}}=64,2{ }^{\circ} \mathrm{C}$ Primer reverso AGGCTCGAGTCAGAACATGGACGGGTCGATC $58,1 \% \mathrm{CG} \quad \mathrm{T}_{\mathrm{m}}=65,3{ }^{\circ} \mathrm{C}$ Fonte: Autoria própria.

A sequência final do vetor recombinante pETSUMO-CDK11 $\Delta$ pode ser observada na Figura 78. 
Figura 78 - Sequência do cDNA da CDK11 $\triangle$ em pETSUMO, com o códon de início (laranja), cauda de histidina (roxo), sequência referente a proteína SUMO (amarelo), sítio da EcorI (verde claro), sequência referente a CDK11 $\Delta$, (vermelho), o códon de terminação (verde escuro) e o sítio da XhoI (azul) destacados.

....ATGGGCAGCAGCCATCATCATCATCATCACAGCAGCGGCCTGGTGCCGCGCGGC AGCCATATGGCTAGCATGTCGGACTCAGAAGTCAATCAAGAAGCTAAGCCAGAGG TCAAGCCAGAAGTCAAGCCTGAGACTCACATCAATTTAAAGGTGTCCGATGGATCT TCAGAGATCTTCTTCAAGATCAAAAAGACCACTCCTTTAAGAAGGCTGATGGAAGC GTTCGCTAAAAGACAGGGTAAGGAAATGGACTCCTTAAGATTCTTGTACGACGGTA TTAGAATTCAAGCTGATCAGACCCCTGAAGATTTGGACATGGAGGATAACGATATT ATTGAGGCTCACAGAGAACAGATTGGTGGATCCGAATTCGGCTGCCGTAGCGTCGA GGAGTTCCAGTGCCTGAACCGTATCGAGGAGGGCACCTATGGCGTGGTCTACCGTG CAAAAGACAAGAAAACAGATGAAATTGTGGCTCTGAAGCGTCTGAAGATGGAGAA GGAGAAGGAGGGCTTCCCGATCACCTCCCTGCGTGAGATCAACACCATCCTCAAGG CCCAGCATCCGAACATTGTCACCGTTCGTGAGATTGTGGTGGGCAGCAACATGGAC AAGATCTACATCGTGATGAACTACGTGGAGCACGACCTCAAGAGCCTGATGGAGAC CATGAAACAGCCGTTCCTGCCAGGCGAGGTGAAGACCCTGATGATCCAGCTGCTGC GTGGCGTGAAACACCTGCACGACAACTGGATCCTGCACCGTGACCTCAAGACCTCC AACCTGCTGCTGAGCCACGCCGGCATCCTCAAGGTGGGTGATTTTGGCCTGGCGCG TGAGTACGGCTCCCCTCTGAAGGCCTACACCCCGGTCGTGGTGACCCAGTGGTACC GCGCCCCAGAGCTGCTGCTTGGTGCCAAGGAATACTCCACCGCCGTGGACATGTGG TCAGTGGGCTGCATCTTCGGCGAGCTGCTGACTCAGAAGCCTCTGTTCCCGGGCAA TTCGGAAATCGATCAGATCAACAAAGTGTTCAAGGAGCTGGGCACCCCGAGTGAG AAAATCTGGCCGGGCTACAGTGAGCTCCCAGTAGTCAAAAAGATGACCTTCAGCGA GCACCCGTACAACAACCTCCGCAAGCGCTTCGGCGCTCTGCTCTCAGACCAGGGCT TCGACCTCATGAACAAGTTCCTGACCTACTTCCCGGGCCGTCGTATCAGCGCTGAG GACGGCCTCAAGCATGAGTATTTCCGCGAGACCCCGCTCCCGATCGACCCGTCCAT GTTCTGACTCGAGCCT...

Fonte: Autoria própria.

Inicialmente foram realizados testes de temperatura de anelamento para os primers para amplificação da CDK11 , as temperaturas testadas foram, 61,0;65,1;67,7; 69,8 e $72,0^{\circ} \mathrm{C}$. A temperatura escolhida foi a de $69,8^{\circ} \mathrm{C}$ (Figura 79).

Figura 79 - Amplificação da CDK11 1 em temperatura de $69,8^{\circ} \mathrm{C}$.

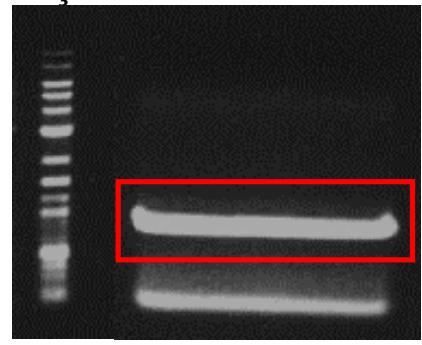

Fonte: Autoria própria.

Em seguida foi realizada a digestão do pETSUMO e da CDK11 $\Delta$ com as enzimas XhoI (BIOLAB) e EcoRI (THERMO), seguida da purificação por miniprep, posterior ligação da CDK11 1 ao pETSUMO e transformação do produto de ligação em cepa ONE 
SHOT. Para as 3 colônias crescidas foram feitos testes de PCR de colônia e de sequenciamento (Figura 80), a colônia 3 obteve resultado positivo em ambos, e após miniprep tivemos uma concentração de $162,5 \mathrm{ng} / \mu \mathrm{L}$.

Figura 80 - Análise do sequenciamento após alinhamento no programa MultiAlin. Em vermelho destacam-se as regiões idênticas entre a CDK11 $\Delta$ e o resultado do sequenciamento, já em azul as regiões idênticas apenas entre duas sequências.

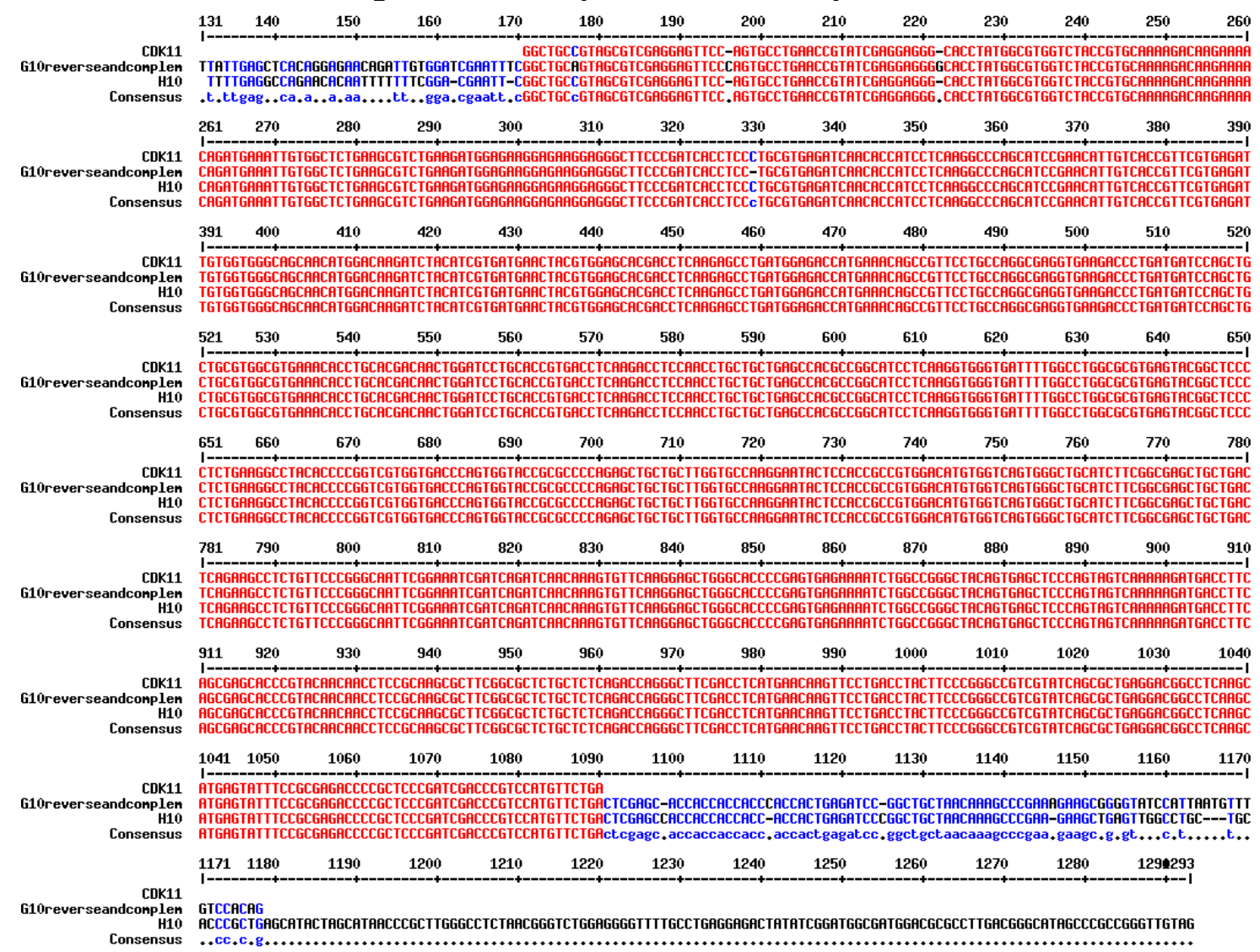

Fonte: Autoria própria.

Após clonagem foram realizados testes de expressão em diferentes condições. As condições testadas foram a $37{ }^{\circ} \mathrm{C}$ por $5 \mathrm{~h}$, a $20^{\circ} \mathrm{C}$ por $24 \mathrm{~h}$, a $12{ }^{\circ} \mathrm{C}$ por $72 \mathrm{~h}$ (Figura 81). A massa da CDK11 $\Delta$ fusionada a proteína SUMO é de $49 \mathrm{kDa}$. Também foi testada a condição $7^{\circ} \mathrm{C}$ por 5 dias (Figura 82). 
Figura 81 - Gel de eletroforese das expressões a 37, 20 e $12^{\circ} \mathrm{C}$ da CDK11 $\Delta$ com a SUMO. Em que $\mathrm{M}$ - marcador; $12 \mathrm{p}$ - pellet a $12^{\circ} \mathrm{C} ; 12 \mathrm{~s}$ - sobrenadante a $12{ }^{\circ} \mathrm{C}$; $20 \mathrm{p}$ - pellet a $20^{\circ} \mathrm{C} ; 20 \mathrm{~s}$ - sobrenadante a $20^{\circ} \mathrm{C} ; 37 \mathrm{p}$ - pellet a $37^{\circ} \mathrm{C}$; $37 \mathrm{~s}$ - sobrenadante a $37^{\circ} \mathrm{C}$.

CDK11 $\Delta+$ SUMO $\rightarrow$

(49kDa)

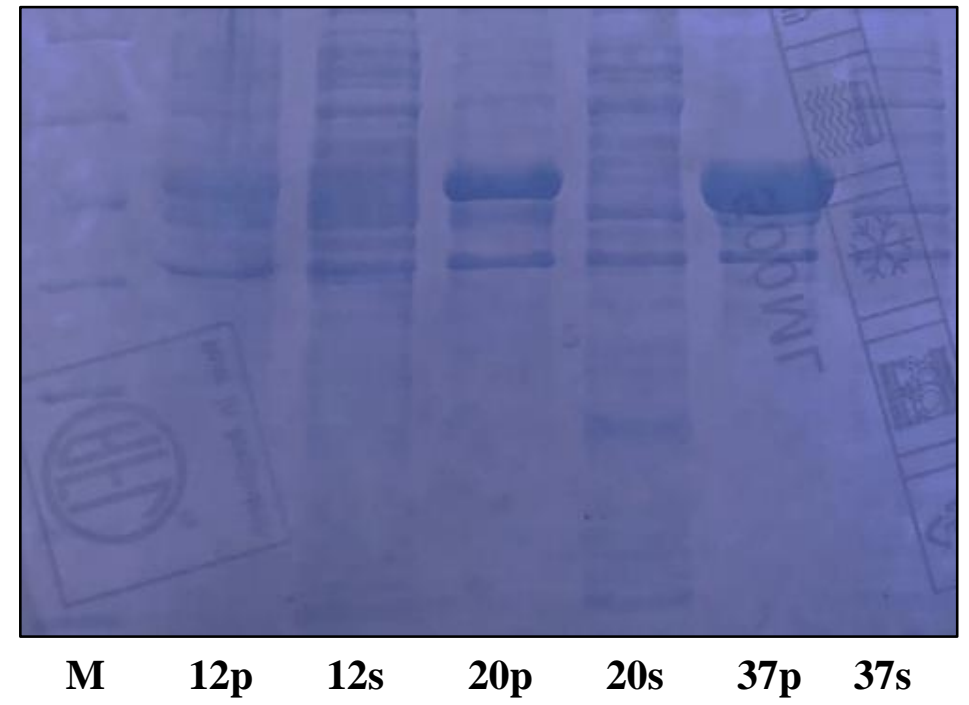

Fonte: Autoria própria.

Figura 82 - Gel de eletroforese da expressão a $7^{\circ} \mathrm{C}$ da CDK11 $\triangle$ com a SUMO. Em que $\mathrm{M}$ - marcador; $7 \mathrm{p}$ - pellet a $7^{\circ} \mathrm{C} ; 7 \mathrm{~s}$ - sobrenadante a $7^{\circ} \mathrm{C}$.

CDK11 $\Delta+$ SUMO $\rightarrow$ (49kDa)

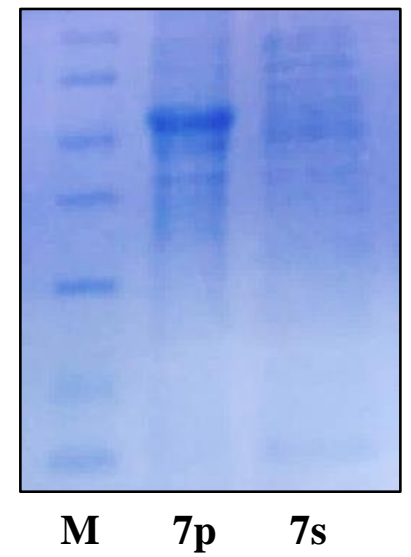

Fonte: Autoria própria.

A melhor condição foi a $12{ }^{\circ} \mathrm{C}$ por $72 \mathrm{~h}$, então essa temperatura foi testada por 2 , 3 e 4 dias de expressão em meio LB (Figura 83) e em meio LB otimizado (Figura 84). Mas em nenhuma das condições testadas foi obtida a proteína em sua forma solúvel. 
Figura 83 - Gel de eletroforese das expressões a $12^{\circ} \mathrm{C}$ em meio LB da CDK11 $\Delta$ com a SUMO. Em que M - marcador; $2 p$ - pellet após 2 dias; $2 \mathrm{~s}$ - sobrenadante após 2 dias; $3 p$ - pellet após 3 dias; $3 \mathrm{~s}$ - sobrenadante após 3 dias; $4 \mathrm{p}$ - pellet após 4 dias; $4 \mathrm{~s}$ - sobrenadante após 4 dias.

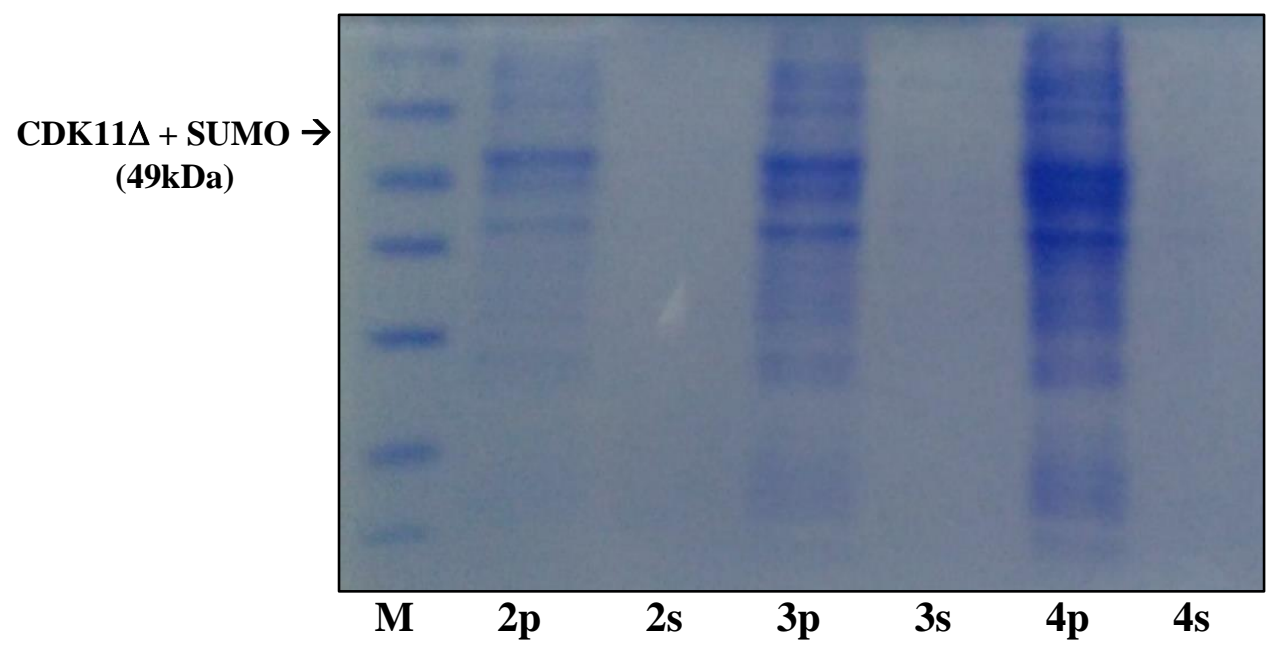

Fonte: Autoria própria.

Figura 84 - Gel de eletroforese das expressões a $12^{\circ} \mathrm{C}$ em meio LB otimizado da CDK11 $\Delta$ com pETSUMO. Em que M - marcador; $2 \mathrm{p}$ - pellet após 2 dias; $2 \mathrm{~s}$ - sobrenadante após 2 dias; $3 \mathrm{p}$ - pellet após 3 dias; $3 \mathrm{~s}$ - sobrenadante após 3 dias; $4 \mathrm{p}$ - pellet após 4 dias;

$4 \mathrm{~s}$ - sobrenadante após 4 dias.

CDK11 $\Delta+$ SUMO $\rightarrow$

(49kDa)

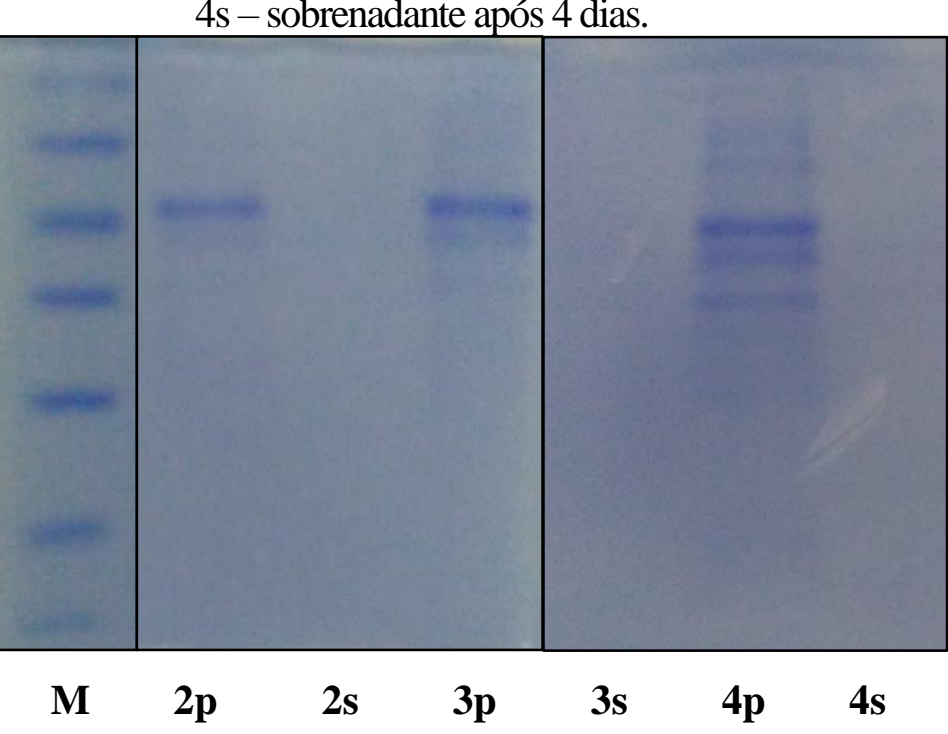

Fonte: Autoria própria.

\subsection{Purificação e caracterização biofísica da CDK8}

A CDK8 está entre as CDKs da linha de pesquisa do nosso grupo de pesquisa e foi tema da tese de doutorado da aluna Buana Carvalho de Almeida, que obteve a proteína pelo mesmo protocolo de reenovelamento apresentado no presente trabalho, porém não teve tempo hábil de realizar sua caracterização estrutural. Sendo assim, durante o período 
do meu doutoramento, e em colaboração com a aluna de doutorado Fernanda Coelho, também do grupo, realizamos ensaios de caracterização estrutural da CDK8 humana.

Juntamente com a CDK8, outras CDKs atuam na regulação da transcrição em um processo complexo que envolve vários fatores de transcrição, que atuam como ativadores e/ou repressores da RNAP II (GALBRAITH et al., 2013).

A CDK8 é ativada após a ligação da ciclina $\mathrm{C}$ e sua atividade aumenta quando o complexo CDK8/Ciclina C é fosforilado pela CDK7. Quando fosforilada na Ser182 há uma mudança conformacional que favorece sua ligação ao ATP, nesse processo vários aminoácidos são fosforilados e após a desfosforilação dos demais sítios por fosfatases, a CDK8 estará completamente ativa (RZYMSKI et al., 2015).

Associada a regulação da RNA Polimerase 2 a CDK8 é considerada tanto como um regulador positivo, como um regulador negativo do processo transcricional. Além disso, a CDK8 também atua no ciclo celular controlado e na progressão do câncer ao atuar em vias de sinalização celular (SZILAGYI e GUSTAFSSON, 2013).

A expressão da CDK8, lise, reenovelamento, purificação e caracterização por CD e por espectroscopia de fluorescência foram feitas conforme as etapas descritas para a CDK11 1 . Os resultados obtidos após purificação por cromatografia de afinidade podem ser observados na Figura 85.

Figura 85 - Gel de eletroforese com os resultados da lise, reenovelamento e purificação da CDK8. Em que M - marcador; 5p - pellet após indução e após lavagens;

SDSs - sobrenadante após reenovelamento; I - impurezas (primeiro pico após aplicação da amostra SDSs na coluna de Níquel) e CDK8 - proteína de interesse (segundo pico após aplicação da amostra SDSs na coluna e Níquel).

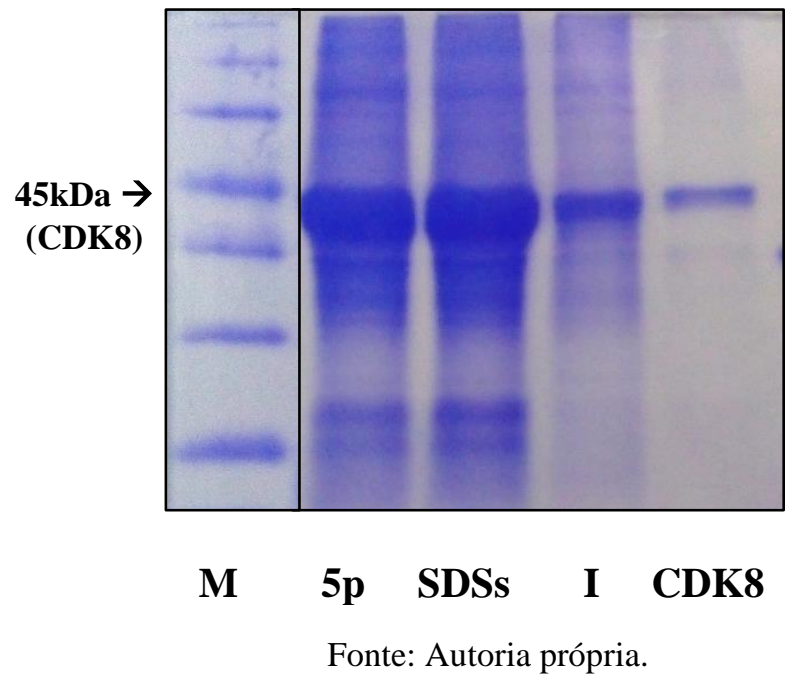


O rendimento obtido foi de $45 \mathrm{mg}$ da proteína recombinante CDK8 por um litro de meio de cultura de expressão, com 95\% de pureza, avaliada pelo ImageJ.

O espectro de dicroísmo circular (Figura 86) mostrou três picos pronunciados, um mínimo próximo a $222 \mathrm{~nm}$ e outro a $208 \mathrm{~nm}$ e um máximo próximo a $193 \mathrm{~nm}$, essas bandas são características de proteínas contendo principalmente hélices $\alpha$ (GREENFIED, 2006).

Figura 86 - Espectro de dicroísmo circular para a CDK8 a $4 \mu \mathrm{M}$ em tampão Tris-HCl 20 mM, $\mathrm{NaCl} 50 \mathrm{mM}$, glicerol a $5 \%$ (v/v), $\beta$-mercaptoetanol $10 \mathrm{mM}, \mathrm{pH} 7,4$.

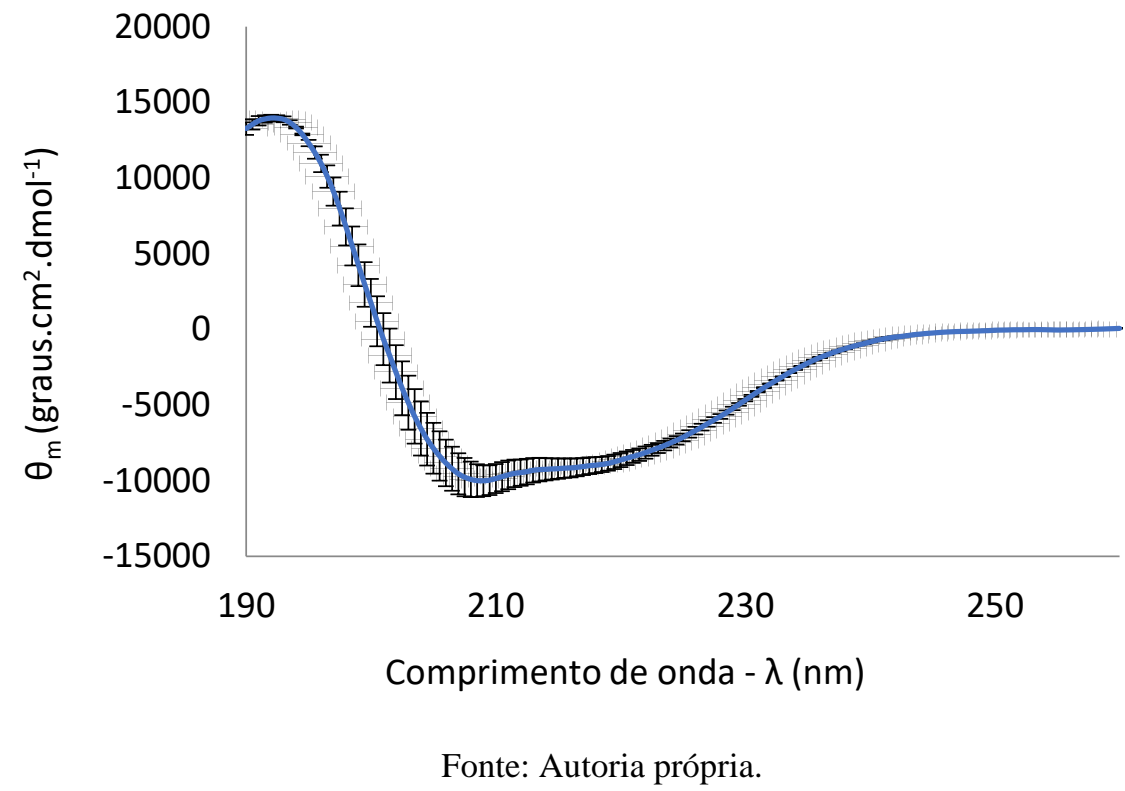

Com o tratamento dos dados, utilizando 13 espectros de base na faixa de $205 \mathrm{~nm}$ a $260 \mathrm{~nm}$, obteve-se que a proteína obtida contém cerca de 30\% de hélices $\alpha$ e $19 \%$ de folhas $\beta$. Comparando esse resultado com os resultados obtido por difração de raios-X para CDK8 de 33\% de hélices $\alpha$ e de $9 \%$ de folhas $\beta$ (código PDB - 5hvy) é possível confirmar que o resultado obtido está próximo do esperado, considerando que nesta opção, o erro do programa é relatado em 4,84\% (CDNN MANUAL DO USUÁRIO) e que alguns conjuntos tendem a superestimar a quantidade de folhas $\beta$ em dados menores que 208 nm (GREENFIED e FASMAN, 1969).

Por CD, a análise da estabilidade térmica da CDK8 foi monitorada a $208 \mathrm{~nm}$ na faixa de temperatura de $20{ }^{\circ} \mathrm{C}$ a $90{ }^{\circ} \mathrm{C}$, a cada incremento de $1{ }^{\circ} \mathrm{C}$, o resultado obtido foi tratado usando o programa Origin2019, com o ajuste de Boltzmann (Figura 87). 
Figura 87 - Avaliação da estabilidade térmica de CDK8 por dicroísmo circular em $208 \mathrm{~nm}$.

CDK8 a $4 \mu \mathrm{M}$ em tampão Tris- $\mathrm{HCl} 20 \mathrm{mM}, \mathrm{NaCl} 50 \mathrm{mM}$, glicerol a 5\% (v/v),

$10 \mathrm{mM} \beta$-mercaptoetanol, $\mathrm{pH} 7,4$

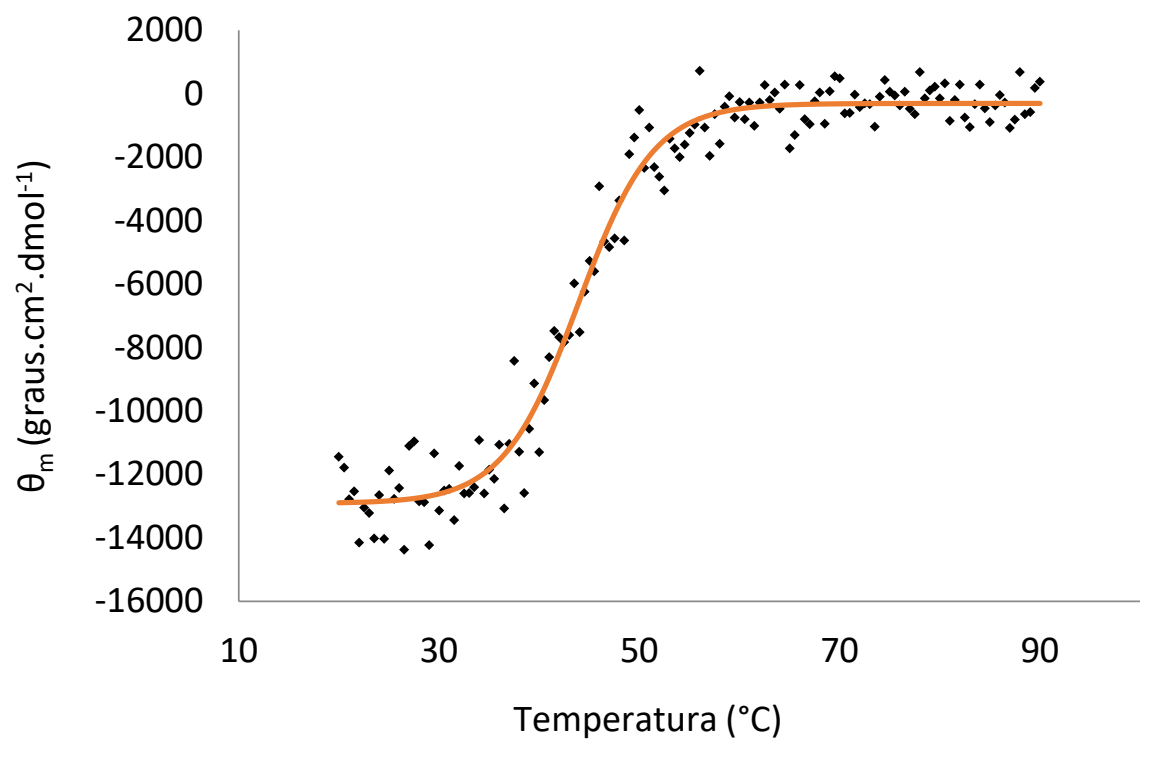

Fonte: Autoria própria.

Verificou-se que a proteína CDK8 perde metade de sua estrutura a partir de $43,9^{\circ} \mathrm{C}$, valor próximo ao de Brown et al. (2015) que encontrou valores entre 40 e $55^{\circ} \mathrm{C}$ para outras CDKs. A análise em diferentes comprimentos de onda (Figura 88), mostrou que o espectro característico da CDK8 se altera após os $35^{\circ} \mathrm{C}$.

Figura 88 - Avaliação da estabilidade térmica de CDK8 por dicroísmo circular em diferentes temperaturas.

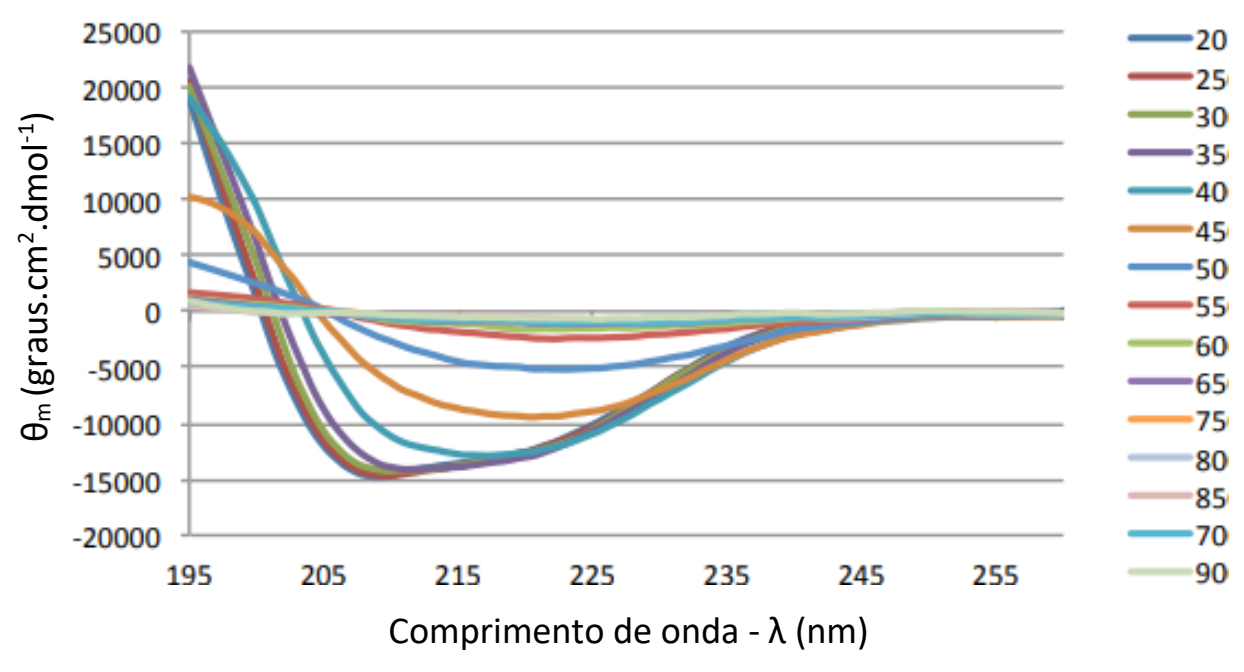

Fonte: Autoria própria. 
Por espectroscopia de emissão de fluorescência a desnaturação da proteína CDK8 foi verificada após incubação da proteína em diferentes concentrações de ureia (0 M a 8 M), a perda de estrutura terciária, observada pelo deslocamento do máximo de emissão de $334 \mathrm{~nm}$ para $345 \mathrm{~nm}$, foi pronunciada após $3 \mathrm{M}$ de ureia (Figura 89).

Figura 89 - Espectro de emissão de fluorescência para CDK8 frente a diferentes concentrações de ureia (de $0 \mathrm{M}$ a $8 \mathrm{M}$ ).

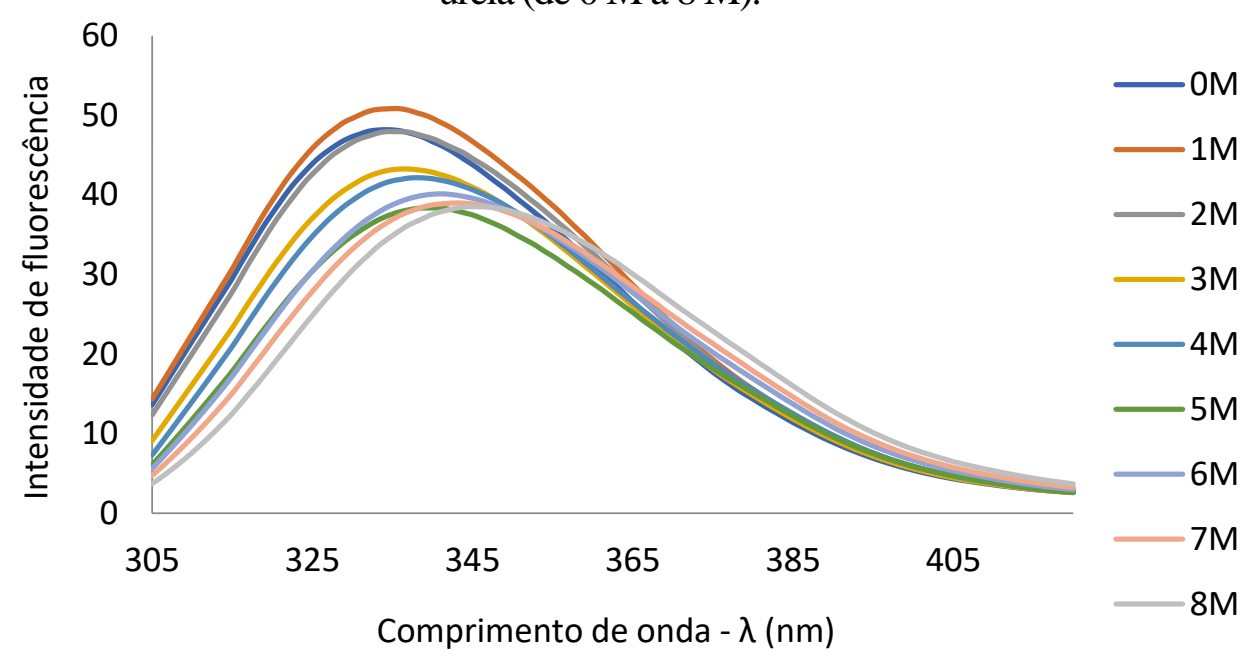

Fonte: Autoria própria.

A interação das CDK8 com a molécula de ATP também foi estudada (Figura 90) e verificou-se a interação da proteína com seu ligante ATP após supressão da fluorescência observada no espectro de emissão.

Figura 90 - Espectro de emissão de fluorescência para CDK8 frente a diferentes concentrações de ATP.

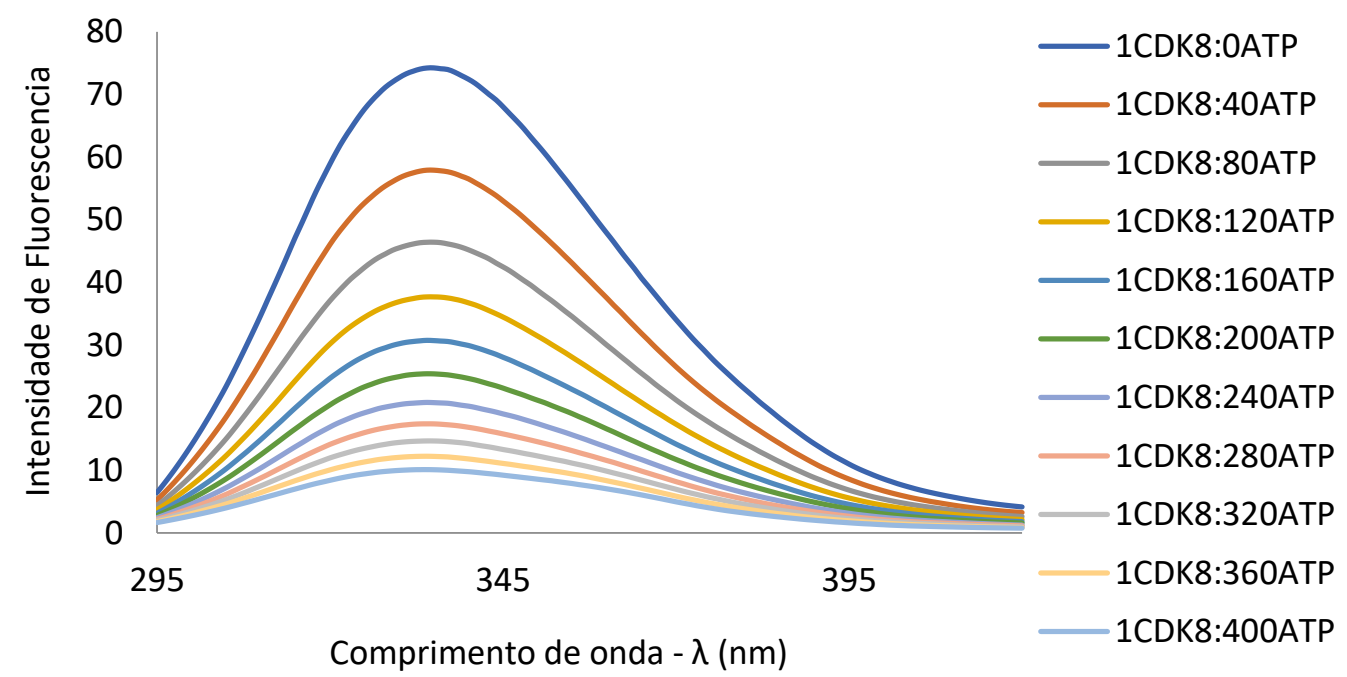

Fonte: Autoria própria. 
A supressão observada para a CDK8 com ATP pelo gráfico $F_{0} / F$ versus [Q] mostrou uma curvatura (Figura 91), indicando uma combinação da supressão colisional e da estática.

Figura 91 - Gráfico $F_{0} / F$ versus [ATP] para a CDK8 em função da concentração de ATP.

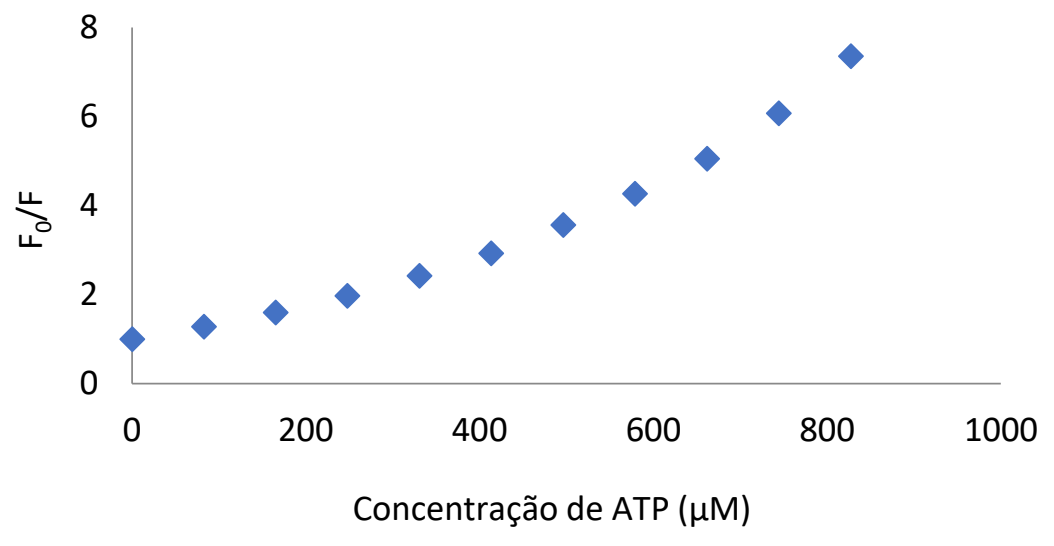

Fonte: Autoria própria.

E utilizando a equação 3, foi construído um gráfico de $\log \left(\mathrm{F}_{0}-\mathrm{F} / \mathrm{F}\right)$ versus $\log [\mathrm{Q}]$ (Figura 92), que fornece $\mathrm{K}_{\mathrm{a}}$ (constante de associação proteína ligante) e n (número de sítios ligantes) conforme equação 3 já relatada no tópico de resultados (MOREIRA et al., 2014 e PRADO, 2017).

Figura 92 - Gráfico $\log \left(\mathrm{F}_{0}-\mathrm{F} / \mathrm{F}\right)$ versus $\log [\mathrm{ATP}]$ para a CDK8 e seu respectivo ajuste linear.

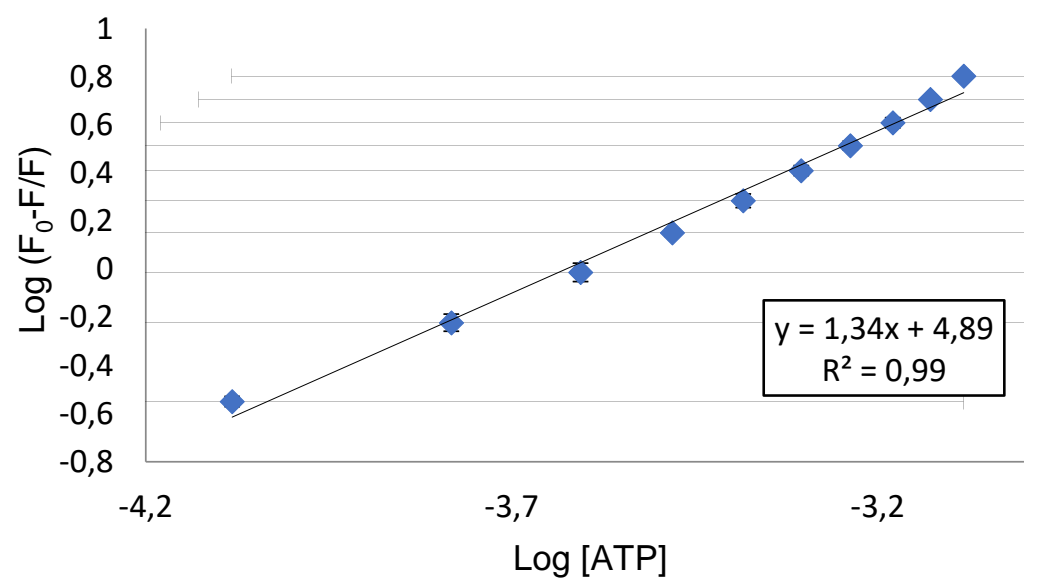

Fonte: Autoria própria.

Considerando $\mathrm{n}=1,34$ e $\mathrm{K}_{\mathrm{a}}=7,75.104 \mathrm{M}^{-1}$, foi observada uma interação do tipo moderada (PRADO, 2017). E a constante de dissociação $\left(K_{d}\right)$ para CDK8 com o ATP foi de $12,9 \mu \mathrm{M}$. 


\subsection{Estudos dos potenciais inibidores $3 a, 3 b$ e $3 f$ com a CDK8}

Os ensaios dos compostos 3a, 3b e 3f, também foram realizados para a CDK8, por espectroscopia de emissão de fluorescência, as amostras foram excitadas a $280 \mathrm{~nm}$ e os espectros de emissão coletados de 295 a 420 nm em concentração crescente dos potenciais inibidores ( 0 a $200 \mu \mathrm{M})$. Os resultados obtidos para a interação dos compostos 3a, 3b e 3f com a CDK8, podem ser observados respectivamente nas Figuras 93, 94 e 95.

Figura 93 - Gráfico $\mathrm{F}_{0} / \mathrm{F}$ versus log [Composto 3a] e ajuste linear para CDK8 e o composto 3 a.

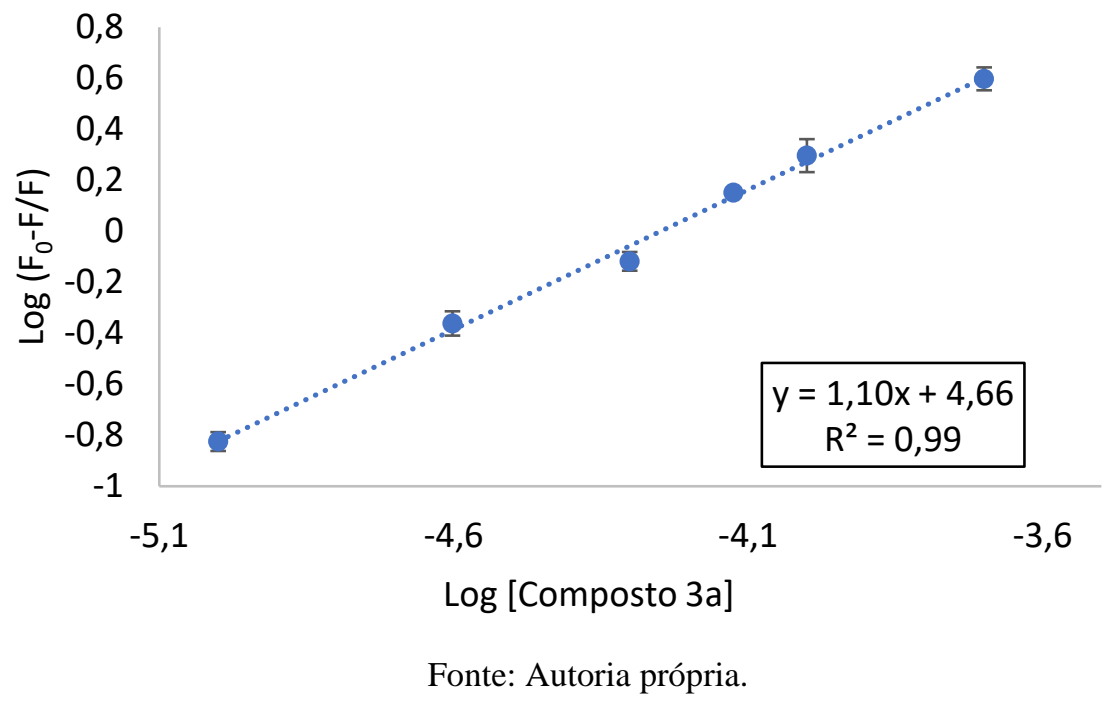

Figura 94 - Gráfico $\mathrm{F}_{0} / \mathrm{F}$ versus log [Composto $3 \mathrm{~b}$ ] e ajuste linear para CDK8 e o composto $3 b$.

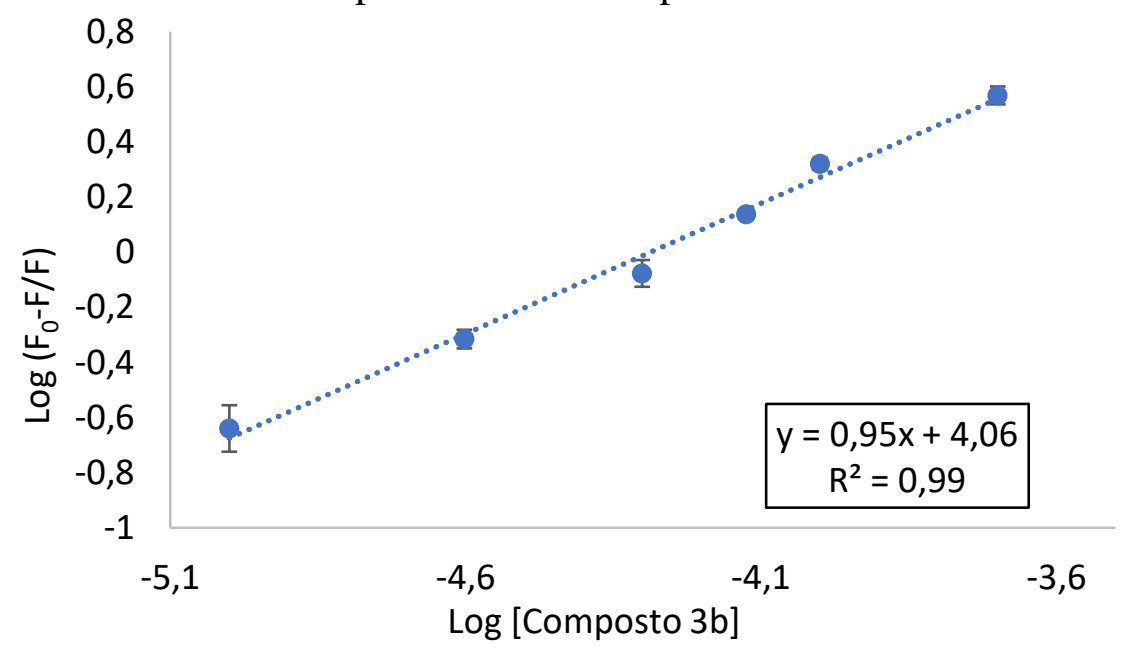

Fonte: Autoria própria. 
Figura 95 - Gráfico $F_{0} / F$ versus log [Composto 3f] e ajuste linear para CDK8 e o composto 3f.

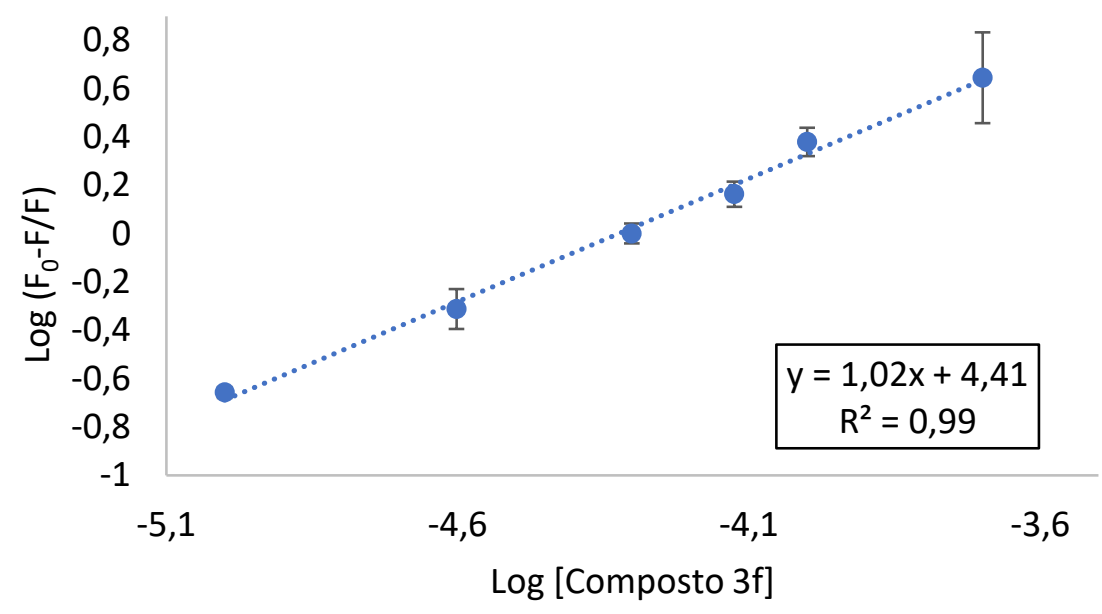

Fonte: Autoria própria.

Após ajuste linear e utilizando a equação 3, contida no tópico de resultados, obteve-se para CDK8 $\mathrm{n}=1,10$ e $\mathrm{K}_{\mathrm{a}}=4,54.10^{4} \mathrm{M}^{-1}$ com o composto $3 \mathrm{a}, \mathrm{n}=0,95$ e $\mathrm{K}_{\mathrm{a}}=1,14.10^{4} \mathrm{M}^{-1}$ com o composto $3 \mathrm{~b}$ e $\mathrm{n}=1,02$ e $\mathrm{K}_{\mathrm{a}}=2,54.10^{4} \mathrm{M}^{-1}$ com o composto 3f. Analisando os valores obtidos, observa-se que em todos ocorreu uma interação moderada. Os valores das constantes de dissociação $\left(\mathrm{K}_{\mathrm{d}}\right)$ para CDK8 foram de $22 \mu \mathrm{M}$, $87 \mu \mathrm{M}$ e de $39 \mu \mathrm{M}$, para os compostos $3 \mathrm{a}, 3 \mathrm{~b}$ e $3 \mathrm{f}$, respectivamente.

\section{BIBLIOGRAFIA}

ABDEL-FATTAH, M.; SAEED, H.; EL-SHENNAWY, L.; SHALABY, M.; EMBABY, A.; ATAYA, F.; MAHMOUD, H.; HUSSEIN, A. The Arabian camel, Camelus dromedarius interferon epsilon: functional expression, in vitro refolding, purification and cytotoxicity on breast cancer cell lines. PLoS ONE, San Francisco, v. 14, n. 9, p. 1-19, 2019.

ALBERTS, B.; JOHNSON, A.; LEWIS, J.; MORGAN, D.; RAFF, M.; ROBERTS, K.; WALTER, P. Fundamentos da biologia celular. 6. ed. Porto Alegre: Artmed, 2017. 1464p.

ARIZA, M. E.; BROOME-POWELL, M.; LAHTI, J. M.; KIDD, V. J.; NELSON, M. A. Fas-induced apoptosis in human malignant melanoma cell lines is associated with the activation of p34cdc2related PITSLRE protein kinases. Journal of Biological Chemistry, New York, v. 274, n. 40, p. 28505-28513, 1999.

ATKINS, P.; PAULA, J. Physical chemistry for the life sciences. 2. ed. New York: W. H. Freeman and Company: Artmed, 2011. 618 p. 
AUTODOCK. La Jolla: The Scripps Research Institute, 2013. Disponível em: http://autodock.scripps.edu/resources/adt. Acesso em: 23 jan. 2020.

AZEVEDO, W. F.; LECLERC, S.; MEIJER, L.; HAVLICEK, L.; STRNAD, M.; KIM, S. H. Inhibition of cyclin-dependent kinases by purine analogues crystal structure of human cdk2 complexed with roscovitine. European Journal of Biochemistry, Chichester, v. 243, n. 1-2, p. 518-526, 1997.

BAJIĆ, V.; STANOJEVIĆ, B.; ZIVKOVIĆ, L.; CABARKAPA, A.; PERRY, G.; ARENDT, T.; SPREMO-POTPAREVIĆ, B. Cyclin dependent kinase 11, neuroinflammation and Alzheimer's disease: a review. Journal of Clinical \& Cellular Immunology, Los Angeles, v. 6, n. 2, p. 305, 2015.

BAJIĆ, V. P.; SU, B.; LEE, H. G.; KUDO, W.; SIEDLAK, S. L.; ZIVKOVIĆ, L.; SPREMO-POTPAREVIĆ, B.; DJELIC, N.; MILICEVIC, Z.; SINGH, A.; FAHMY, L.; WANG, X.; SMITH, M.; ZHU, X. Mislocalization of CDK11/PITSLRE, a regulator of the G2/M phase of the cell cycle, in Alzheimer disease. Cellular \& Molecular Biology Letters, London, v. 16, n. 3, p. 359-372, 2011.

BROWN, N. R.; KOROLCHUK, S.; MARTIN, M. P.; STANLEY, W. A.; MOUKHAMETZIANOV, R.; NOBLE, M. E. M.; ENDICOTT, J. A. CDK1 structures reveal conserved and unique features of the essential cell cycle CDK. Nature Communications, London, v. 6, n. 1, p. 6769, 2015.

BUNNELL, B. A.; ADAMS, D. E.; LAHTI, J. M.; KIDD, V. J.; HEATH, L. S. Increased expression of a 58-kDa protein kinase leads to changes in the $\mathrm{CHO}$ cell cycle. Proccedings of the National Academy of Sciences, Washington, v. 87, n. 19, p. 74677471, 1990.

BUTT, T. R.; EDAVETTAL, S. C.; HALL, J. P.; MATTERN, M. R. SUMO fusion technology for difficult-to-express proteins. Protein Expression and Purification, Maryland Heights, v. 43, n. 1, p. 1-9, 2005.

CARY, D. C.; FUJINAGA, K.; PETERLIN, B. M. Molecular mechanisms of HIV latency. The Journal of Clinical Investigation, Ann Arbor, v. 126, n. 2, p. 448-54, 2016.

CASE, D. A.; CHEATHAM, T. E.; DARDEN, T.; GOHLKE, H.; LUO, R.; MERZ, K. M.; ONUFRIEV, A.; SIMMERLING, C.; WANG, B.; WOODS, R. J. The amber biomolecular simulation programs. Journal of Computational Chemistry, Hoboken, v. 26, n. 16, p. 1668-1688, 2005.

CEE, V. J.; CHEN, D. Y.; LEE, M. R.; NICOLAOU, K. C. Cortistatin A is a highaffinity ligand of protein kinases ROCK, CDK8, and CDK11. Angewandte Chemie International Edition, Weinheim, v. 48, n. 47, p.8952-8957, 2009.

CHI, Y.; ZHANG, C.; ZONG, H.; HONG, Y.; KONG, X.; LIU, H.; ZOU, W.; WANG, Y.; YUN, X.; GU, J. Thr-370 is responsible for CDK11p58 autophosphorylation, dimerization, and kinase activity. The Journal of Biological Chemistry, New York, v. 286, n. 3, p. 1748-1757, 2011. 
CHOHAN, T. A.; QAYYUM, A.; REHMAN, K.; TARIQ, M.; AKASH, M. S. H. An insight into the emerging role of cyclin-dependent kinase inhibitors as potential therapeutic agents for the treatment of advanced cancers. Biomedicine $\boldsymbol{\&}$

Pharmacotherapy, Issy les Moulineaux Cedex v. 107, p. 1326-1341, 2018.

CICENAS, J.; KALYAN, K.; SOROKINAS, A.; STANKUNAS, E.; LEVY, J.; MESKINYTE, I.; STANKEVICIUS, V.; KAUPINIS, A.; VALIUS, M. Roscovitine in cancer and other diseases. Annals of Translational Medicine, AME Publishing Company, v. 3, n. 10, p. 135, 2015.

CORNELIS, S.; BRUYNOOGHE, Y.; DENECKER, G.; HUFFEL, S. V.; TINTON, S.; BEYAERT, R. Identification and characterization of a novel cell cycle-regulated internal ribosome entry site. Molecular Cell, Cambridge, v. 5, n. 4, p. 597-605, 2000.

DEVLIN, T. M. Manual de bioquímica com correlações clínica. 7. ed. São Paulo: Blucher, 2011. 1290p.

DICKINSON, L. A.; EDGAR, A. J.; EHLEY, J; GOTTESFELD, J. M. Cyclin L is an RS domain protein involved in pre-mRNA splicing. Journal of Biological Chemistry, New York, v. 277, n. 28, p. 25465-25473, 2002.

DRENTH, J. Principles of proteins x-ray crystallography. 3. ed. New York: Springer Verlag, 2007. 332 p.

DROGAT, J.; MIGEOT, V.; MOMMAERTS, E.; MULLIER, C.; DIEU, M.; BAKEL, V. H.; HERMAND, D. Cdk11-CyclinL controls the assembly of the RNA polymerase II Mediator complex. Cell Reports, Cambridge, v. 2, n. 5, p. 1068-1076, 2012.

DUAN, Y.; HE, X.; YANG, H.; JI, Y.; TAO, T.; CHEN, J.; HU, L.; ZHANG, F.; LI, X.; WANG, H.; SHEN, A.; LU, X. Cyclin D3/CDK11(p58) complex involved in schwann cells proliferation repression caused by lipopolysaccharide. Inflammation, New York, v. 33, n. 3, p. 189-199, 2010.

DUAN, Z.; ZHANG, J.; CHOY, E.; HARMON, D.; LIU, X.; NIELSEN, P.; MANKIN, H.; GRAY, N. S.; HORNICEK, F. J. Systematic kinome shRNA screening identifies CDK11 (PITSLRE) kinase expression is critical for osteosarcoma cell growth and proliferation. Clinical Cancer Research, Philadelphia, v. 18, n. 17, p. 4580-4588, 2012.

EVANGELISTA, M.; LIM, T. Y.; LEE J.; PARKER, L.; ASHIQUE, A.; PETERSON, A. S.; YE, W.; DAVIS, D. P.; DE SAUVAGE, F. J. Kinome siRNA screen identifies regulators of ciliogenesis and hedgehog signal transduction. Science signaling,

Philadelphia, v. 1, n. 39, p. ra7, 2008.

EXPASY. Lausanne: Swiss Institute of Bioinformatics, [20--]. Disponível em: https://web.expasy.org/translate. Acesso em: 19 maio 2017.

FENG, Y.; ARIZA, M. E.; GOULET, A.; SHI, J.; NELSON, M. A. Death-signalinduced relocalization of cyclin-dependent kinase 11 to mitochondria. Biochemical Journal, London, v. 392, n. 1, p. 65-73, 2005. 
FENG, Y.; SASSI, S.; SHEN, J. K.; YANG, X.; GAO, Y.; OSAKA, E.; ZHANG, J.; YANG, S.; YANG, C.; MANKIN, H. J.; HORNICEK, F. J.; DUAN, Z. Targeting CDK11 in osteosarcoma cells using the CRISPR-Cas9 system. Journal of Orthopaedic Research, Hoboken, v. 33, n. 2, p. 199-207, 2015.

FINN, R. S.; MARTIN, M.; RUGO, H. S.; JONES, S.; IM, S. A.; GELMON, K.; HARBECK, N.; LIPATOV, O. N.; WALSHE, J. M.; MOULDER, S.; GAUTHIER, E.; DONGRUI, R. L.; RANDOLPH, S.; DIERAS, V.; SLAMON, D. J. Palbociclib and letrozole in advanced breast cancer. The New England Journal of Medicine, Waltham, v. 375, n. 20, p. 1925-1936, 2016.

GAHMEN, U. S.; DE BONDT, H. L.; KIM, S. H. High-resolution crystal structures of human cyclin-dependent kinase 2 with and without ATP: bound waters and natural ligand as guides for inhibitor design. Journal of Medicinal Chemistry, Washington, v. 39, n. 23, p. 4540-4546, 1996.

GALBRAITH, M. D.; ALLEN, M. A.; BENSARD, C. I.; WANG, X.; SCHWINN, M. K.; QIN, B.; LONG, H. W.; DANIELS, D. L.; HAHN, W. C.; DOWELL, R. D.; ESPINOSA, J. M. HIF1A employs CDK8-mediator to stimulate RNAPII elongation in response to hypoxia. Cell, Cambridge, v. 153, n. 6, p. 1327-1339, 2013.

GREENFIELD, N.; FASMAN, G. D. Computed circular dichroism spectra for the evaluation of protein conformation. Biochemistry, Washington, v. 8, n. 10, p.41084116, 1969.

GREENFIELD, N. J. Using circular dichroism spectra to estimate protein secondary structure. Nature Protocols, London, v. 1, n. 6., p. 2876-890, 2006.

GREIFENBERG, A. K.; HOENIG, D.; PILAROVA, K.; DUSTER, R.; BARTHOLOMEEUSEN, K.; BOSKEN, C. A.; ANAND, K.; BLAZEK, D.; GEYER, M. Structural and functional analysis of the CDK13/cyclin K complex. Cell Reports, Cambridge, v. 14, n. 2, p. 320-331, 2016.

GRIGOROUDIS, A. I.; MCINNES, C.; PREMNATH, P. N.; KONTOPIDIS, G.

Efficient soluble expression of active recombinant human cyclin A2 mediated by E. coli molecular chaperones. Protein Expression and Purification, Maryland Heights, v. 113, p. 8-16, 2015.

GUARDAVACCARO, D.; PAAGANO, M. Stabilizers and destabilizers controlling cell cycle oscillators. MolecularCell, Cambridge, v. 22, n. 1, p. 1-4, 2006.

HE, C.; OHNISHI, K. Efficient renaturation of inclusion body proteins denatured by SDS. Biochemical and Biophysical Research Communications, Maryland Heights, v. 490, n. 4, p. 1250-1253, 2017. 
HOUSDEN, B. E.; VALVEZAN, A. J.; KELLEY, C.; SOPKO, R.; HU, Y.; ROESEL, C.; LIN, S.; BUCKNER, M.; TAO, R.; YILMAZEL, B.; MOHR, S. E.; MANNING, B. D.; PERRIMON, N. Identification of potential drug targets for tuberous sclerosis complex by synthetic screens combining CRISPR-based knockouts with RNAi. Science Signaling, Washington, v. 8, n. 393, p. rs9, 2015.

HU, D.; MAYEDA, A.; TREMBLEY, J. H.; LAHTI, J. M.; KIDD, V. J. CDK11 complexes promote pre-mRNA splicing. The Journal of Biological Chemistry, New York, v. 278, n. 10, p. 8623-8629, 2003.

HU, D.; VALENTINE, M.; KIDD, V. J.; LAHTI, J. M. CDK11p58 is required for the maintenance of sister chromatid cohesion. Journal Cell Science, Cambridge, v. 120, n. 14, p. 2424-2434, 2007.

IDTDNA. Coralville: Integrated DNA Technologies, [20--]. Disponível em: https://www.idtdna.com/calc/analyzer. Acesso em: 19 de maio de 2017.

I-TASSER. [S. l.: s. n.], [20--]. Disponível em: https://zhanglab.ccmb.med.umich.edu/I-TASSER. Acesso em: 03 jul. 2019.

JI, Y.; XIAO, F.; SUN, L.; QIN, J.; SHI, S.; YANG, J.; LIU, Y.; ZHOU, D.; ZHAO, J.; SHEN, A. Increased expression of CDK11p58 and cyclin D3 following spinal cord injury in rats. Molecular and Cellular Biochemistry, New York, v. 309, n. 1-2, p. 4960, 2008

JIA, B.; CHOY, E.; COTE, G.; HARMON, D.; YE, S.; KAN, Q.; MANKIN, H.; HORNICEK, F.; DUAN, Z. Cyclin-dependent kinase 11 (CDK11) is crucial in the growth of liposarcoma cells. Cancer Letters, Shannon, v. 342, n. 1, p. 104-112, 2014.

KELLY, S. M.; JESS, T. J.; PRICE, N. C. How to study protein by circular dichroism, Biochimica et Biophysica Acta. Proteins and proteomics, Amsterdam, v. 1751, n. 2, p. 119-139, 2005.

KHAN ACADEMY. Caminhos de retransmissão de sinais. Mountain View, [20--]. Disponível em: https://pt.khanacademy.org/science/biology/cell-signaling/mechanismsof-cell-signaling/a/intracellular-signal-transduction. Acesso em: 26 mar. 2018.

KONG, X.; GAN, H.; HAO, Y.; CHENG, C.; JIANG, J.; HONG, Y.; YANG, J.; ZHU, H.; CHI, Y.; YUN, X.; GU, J. CDK11p58 phosphorylation of PAK1 Ser174 promotes DLC2 binding and roles on cell cycle progression. Journal of Biochemistry, Oxford, $v$. 146, n. 3, p. 417-427, 2009.

KREN, B. T.; UNGER, G. M.; ABEDIN, M. J.; VOGEL, R. I.; HENZLER, C. M.; AHMED, K.; TREMBLEY, J. H. Preclinical evaluation of cyclin dependent kinase 11 and casein kinase 2 survival kinases as RNA interference targets for triple negative breast cancer therapy. Breast Cancer Research, London, v. 17, n. 1, p. 19, 2015. 
LAKOWICZ, J. R. Principles of fluorescence spectroscopy. 3. ed. New York: Springer, 2006. $953 \mathrm{p}$.

LEOPOLDINO, A. M.; CANDURI, F.; CABRAL, H.; JUNQUEIRA, M.; MARQUI, A. B. T.; APPONI, L. H.; FONSECA, I. O.; DOMONT, G. B.; SANTOS, D. S.; VALENTINI, S.; RODRIGUEZ, G. O. B.; FOSSEY, M. A.; AZEVEDO, W. F.; TAJARA, E. H. Expression, purification and circular dichroism analysis of human CDK9. Protein Expression and Purification, Maryland Heights, v. 47, n. 2, p. 614620, 2006.

LIAO, Y.; SASSI, S.; HALVORSEN, S.; FENG, Y.; SHEN, J.; GAO, Y.; COTE, G.; CHOY, E.; HARMON, D.; MANKIN, H.; HORNICEK, F.; DUAN, Z. Androgen receptor is a potential novel prognostic marker and oncogenic target in osteosarcoma with dependence on CDK11. Scientific Reports, London, v. 7, n. 1, p. 43941, 2017.

LIN, A.; GIULIANO, C. J.; PALLADINO, A.; JOHN, K. M.; ABRAMOWICZ, C.; YUAN, M. L.; SAUSVILLE, E. L.; LUKOW, D. A.; LIU, L.; CHAIT, A. R.;

GALLUZZO, Z. C.; TUCKER, C.; SHELTZER, J. M. Off-target toxicity is a common mechanism of action of cancer drugs undergoing clinical trials. Science Translational Medicine, Washington, v. 11, n. 509, p. 1-18, 2019.

LIU, M.; LIU, H.; CHEN, J. Mechanisms of the CDK4/6 inhibitor palbociclib (PD 0332991) and its future application in cancer treatment (Review). Oncology Reports, Athens v. 39, n. 3, p. 901-911, 2018.

LIU, X.; CHENG, C.; SHAO, B.; WU, X.; JI, Y.; LU, X.; SHEN, A. LPS-stimulating astrocyte-conditioned medium causes neuronal apoptosis via increasing CDK11(p58) expression in PC12 cells through downregulating AKT pathway. Cellular and Molecular Neurobiology, New York, v. 33, n. 6, p. 779-787, 2013.

LIU, X.; GAO, Y.; SHEN, J.; YANG, W.; CHOY, E.; MANKIN, H.; HORNICEK, F. J.; DUAN, Z. Cyclin-dependent kinase 11 (cdk11) is required for ovarian cancer cell growth in vitro and in vivo, and its inhibition causes apoptosis and sensitizes cells to paclitaxel. Molecular Cancer Therapeutics, Philadelphia, v. 15, n. 7, p. 1691-1701, 2016.

LOYER, P.; TREMBLEY, J. H.; GRENET, J. A.; BUSSON, A.; CORLU, A.; ZHAO, W.; KOCAK, M.; KIDD, V. J.; LAHTI, J. M. Characterization of cyclin L1 and L2 interactions with CDK11 and splicing factors: influence of cyclin L isoforms on splice site selection. Journal of Biological Chemistry, New York v. 283, n. 12, p. 7721-7732, 2008 .

LOYER, P.; TREMBLEY, J. H.; LAHTI, J. M.; KIDD V. J. The RNP protein, RNPS1, associates with specific isoforms of the p34cdc2-related PITSLRE protein kinase in vivo. Journal of Cell Science, Cambridge, v. 111, n. 11, p.1495-1506, 1998.

MANNING, G.; WHYTE, D. B.; MARTINEZ, R.; HUNTER, T.; SUDARSANAM, S. The protein kinase complement of the human genome. Science, Washington, v. 298, n. 5600, p. 1912-34, 2002. 
MCPHERSON, A.; GAVIRA, J. A. Introduction to protein crystallization. Acta Crystallographica Section F: structural biology communications, Hoboken, v. 70, n. 1, p. 2-20, 2014.

MEMORIAL UNIVERSITY OF NEWFOUNDLAND. Department of Biology. The cell cycle: DNA replication and mitosis. St. John's, [20--]. Disponível em:

https://www.mun.ca/biology/desmid/brian/BIOL2060/BIOL2060-19/19_39.jpg. Acesso em: 26 mar. 2018.

MIKOLAJCZYK, M.; NELSON, M. A. Regulation of stability of cyclin-dependent kinase CDK11p110 and a caspase processed form, CDK11p46, by Hsp90. Biochemical Journal, London, v. 384, n. 3, p. 461-467, 2004.

MOREIRA, M. B.; FRANCISCATO, D. S.; TOLEDO, K. C. F.; SOUZA, J. R. B.; NAKATANI, H. S.; SOUZA, V. R. Investigation of the fluorescence quenching of bovine and human serum albumin by ruthenium complex. Química Nova, São Paulo v. 38 , n. 2, p. 227-32, 2015.

NAIK, S.; DOTHAGER, R. S.; MARASA, J.; LEWIS, C. L.; PIWNICA-WORMS, D. Vascular endothelial growth factor receptor-1 is synthetic lethal to aberrant $\{$ beta $\}$ catenin activation in colon cancer. Clinical Cancer Research, Philadelphia, v. 15, n. 24, p. 7529-7537, 2009.

NASCIMENTO LAB. Preparação de um sistema biomolecular com o AMBER São Carlos, [20--]. Disponível em: http://nascimento.ifsc.usp.br/wordpress/?page_id=156. Acesso em: 14 abr. 2021.

NATIONAL CENTER FOR BIOTECHNOLOGY INFORMATION. Nucleotide. Bethesda: NCBI, [20--]. Disponível em: https://www.ncbi.nlm.nih.gov/nuccore/. Acesso em: 19 maio 2017.

NELSON, D. L.; COX, M. M. Princípios de bioquímica de Lehninger. 6. ed. Porto Alegre: Artmed, 2014. 1220p.

NI, W.; ZHENG, Z.; LIU, H.; WANG, P.; WANG, H.; SUN, X.; YAN, Q. Combining mutagenesis on Glu281 of prenyltransferase NovQ and metabolic engineering strategies for the increased prenylated activity towards menadione. Applied Microbiology and Biotechnology, Heidelberg, v. 104, n. 10, p. 4371-4382, 2020.

NOBEL PRIZE. The Nobel Prize in physiology or medicine 1992. Edmond H. Fischer. Edwin G. Krebs. Stockholm, 1992. Disponível em: https://www.nobelprize.org/prizes/medicine/1992. Acesso em: 20 fev. 2019.

PAK, V.; EIFLER, T. T.; JÄGER, S.; KROGAN, N. J.; FUJINAGA, K.; PETERLIN, B. M. CDK11 in TREX/THOC regulates HIV mRNA 3' end processing. Cell Host Microbe, Cambridge, v. 18, n. 5, p. 560-570, 2015. 
PAPARIDIS, N. F. S. Obtenção das quinases dependentes de ciclinas CDK9 e CDK11 humanas utilizando um sistema bacteriano de expressão (E. coli). Orientadora: Fernanda Canduri. 128 f. 2015. Dissertação (Mestrado em Química Orgânica e Biológica) - Instituto de Química de São Carlos, Universidade de São Paulo, São Carlos, 2015.

PAPARIDIS, N. F. S.; CANDURI, F. The emerging picture of CDK11: genetic, functional and medicinal aspects. Current Medicinal Chemistry, Sharjah, v. 25, n. 8, p. 880-888, 2018.

PETRETTI, C.; SAVOIAN, M.; MONTEMBAULT, E.; GLOVER, D. M.; PRIGENT, C.; GIET, R. The PITSLRE/CDK11p58 protein kinase promotes centrosome maturation and bipolar spindle formation. EMBO Reports, Heidelberg, v. 7, n. 4, p. 418-424, 2006.

PEYRESSATRE, M.; PRÉVEL, C.; PELLERANO, M.; MORRIS, M. C. Targeting cyclin-dependent kinases in human cancers: from small molecules to peptide inhibitors. Cancers, Basel, v. 7, n. 1, p. 179-237, 2015.

PRADO, A. K. M. Caracterização biofísica da interação entre o flavonoide Morina e a proteína transaldolase isolada de corynebacterium pseudotuberculosis. Orientadora: Fátima Pereira de Souza. 2017. 84 f. Dissertação (Mestrado em Biofísica Molecular) - Instituto de Biociências, Letras e Ciências Exatas, Universidade Estadual Paulista "Júlio de Mesquita Filho", São José do Rio Preto, 2017.

PRANDO, A. Estudos biofísicos de chaperonas de secreção e de interação proteínaligante. Orientadora: Ljubica Tasic. 2012. 258 f. Tese (Doutorado em ciências) Instituto de Química, Universidade Estadual de Campinas, Campinas, 2012.

PSIPRED. London: University College London. Department of Computer Science. Bioinfomratics Group, [20--]. Disponível em: http://bioinf.cs.ucl.ac.uk/psipred/. Acesso em 19 de maio de 2017.

PUSHKAREV, V. V.; KOVZUN, O. I.; PUSHKAREV, V. M.; TRONKO, M. D; PANT, H.; SOINI, Y. The effect of the combined action of roscovitine and paclitaxel on the apoptotic and cell cycle regulatory mechanisms in colon and anaplastic thyroid cancer cells. ISRN Biochemistry, New York, v. 2012, p. 1-6, 2012. RCSB PDB. A structural view of biology. [S. l.], [20--]. Disponível em: https://www.rcsb.org/. Acesso em: 10 fev. 2019.

RZYMSKI T.; MIKULA, M.; WIKLIK, K.; BRZOZKA, K. CDK8 kinase - An emerging target in targeted cancer therapy. Biochimica et Biophysica Acta. Proteins and Proteomics, Amsterdam, v. 1854, n. 10, p. 1617-1629, 2015.

SALOMON-FERRER, R.; GÖTZ, A. W.; POOLE, D.; LE GRAND, S.; WALKER, R. C. Routine microsecond molecular dynamics simulations with AMBER on GPUs. 2. explicit solvent particle mesh ewald. Journal of Chemical Theory Computation, Washington, v. 9, n. 9, p. 3878-3888, 2013. 
SÁNCHEZ-MARTÍNEZ, C.; LALLENA, M. J.; SANFELICIANO, S. G.; DE DIOS, A. Cyclin dependent kinase (CDK) inhibitors as anticancer drugs: recent advances (2015-2019). Bioorganic \& Medicinal Chemistry Letters, Oxford, v. 29, n. 20, p. $126637,2019$.

SAVES. Los Angeles: University of California, [20--]. Disponível em: https://servicesn.mbi.ucla.edu/SAVES/. Acesso em: 26 de junho de 2019.

SHI, J.; FENG, Y.; GOULET, A.; VAILLANCOURT, R. R.; SACHS, N. A.; HERSHEY, J. W.; NELSON, M. A. The p34cdc2-related cyclin-dependent kinase 11 interacts with the 477 subunit of eukaryotic initiation factor 3 during apoptosis. Journal of Biological Chemistry, New York, v. 278, n. 7, p. 5062-5071, 2003.

SHI, J.; HERSHEY, J. W. B.; NELSON, M. A. Phosphorylation of the eukaryotic initiation factor $3 \mathrm{f}$ by cyclin-dependent kinase 11 during apoptosis. FEBS Letters, Oxford, v. 583, n. 6, p. 971-977, 2009.

SILVA, B. V.; HORTA, B. A. C.; ALENCASTRO, R. B.; PINTO, A. C. Proteínas quinases: características estruturais e inibidores químicos. Química Nova, São Paulo, v. 32, n. 2, p. 453-462, 2009.

SKOTHEIM, J. M.; DI TALIA, S.; SIGGIA, E. D.; CROSS, F. R. Positive feedback of G1 cyclins ensures coherent cell cycle entry. Nature, London, v. 454, n. 7202, p. 291296, 2008.

STUDIER, F. W. Protein production by auto-induction in high-density shaking cultures. Protein Expression and Purification, Maryland Heights, v. 41, n. 1, p. 207-234, 2005.

SUN, M.; LI, Z.; ZHANG, Y.; ZHENG, Q.; SUN C. C. Homology modeling and docking study of cyclin-dependent kinase CDK 10. Bioorganic \& Medicinal

Chemistry Letters, Oxford, v. 15, n. 11, p. 2851-2856, 2005.

SVKDIPMPPS-RARECODON. Rare codon calculator (for expression in E.Coli). [S. $l .:$ s. n.], [20--]. Disponível em: http://svkdipmpps-rarecodon-analysis.blogspot.com.br/. Acesso em: 19 maio 2017.

SWISS MODEL. Lausanne: Swiss Institute of Bioinformatics, [20--]. Disponível em: https://swissmodel.expasy.org/interactive. Acesso em: 19 de maio de 2017.

SZILAGYI, Z.; GUSTAFSSON, C. M. Emerging roles of Cdk8 in cell cycle control. Biochimica et Biophysica Acta, Amsterdam, v. 1829, n. 9, p. 916-20, 2013.

TA, B. T. T.; NGUYEN, D. L.; JALA, I.; DONTUMPRAI, R.; PLUMWORASAWAT, S.; AIGHEWI, O.; ONG, E.; SHAWLEY, A.; POTRIQUET, J.; SAICHUA, P.; VAN, D. A.; SRIPA, B.; HOKKE, C. H; SUTTIPRAPA, S. Identification, recombinant protein production, and functional analysis of a T M60-like metallopeptidase, secreted by the liver fluke opisthorchis viverrini. Parasitology International, Amsterdam, v. 75, p. $1-8,2020$. 
TANG, D.; GURURAJAN, R.; KIDD, V. J. Phosphorylation of PITSLRE p110 isoforms accompanies their processing by caspases during Fas-mediated cell death. Journal of Biological Chemistry, New York, v. 273, n. 26, p. 16601-16607, 1998.

TIEDEMANN, R. E.; ZHU, Y. X.; SCHMIDT, J.; SHI, C. X.; SEREDUK, C.; YIN, H.; MOUSSES, S.; STEWART, A. K. Identification of molecular vulnerabilities in human multiple myeloma cells by RNA interference lethality screening of the druggable genome. Cancer Research, Philadelphia, v. 72, n. 3, p. 757-768, 2012.

TINTON, S. A.; SCHEPENS, B.; BRUYNOOGHE, Y.; BEYAERT, R.; CORNELIS, $\mathrm{S}$. Regulation of the cell-cycle-dependent internal ribosome entry site of the PITSLRE protein kinase: roles of Unr (upstream of N-ras) protein and phosphorylated translation initiation factor eIF-2alpha. Biochemical Journal, London, v. 385, n. 1, p. 155-163, 2005.

TREMBLEY, J. H.; HU, D.; HSU, L.; YEUNG, C.; SLAUGHTER, C.; LAHTI, J. M.; KIDD, V. J. PITSLRE p110 protein kinases associate with transcription complexes and affect their activity. Journal of Biological Chemistry, New York, v. 277, n. 4, p. 25892596, 2002.

WEBB, B. MODELLER: program for comparative protein structure modelling by satisfaction of spatial restraints. San Francisco: [s. n.], 2014. Disponível em: https://salilab.org/modeller. Acesso em: 18 jun. 2019.

WHITTAKER, S. R.; MALLINGER, A.; WORKMAN, P.; CLARKE, P. A. Inhibitors of cyclin-dependent kinases as cancer therapeutics. Pharmacology and Therapeutics, Philadelphia, v. 173, p. 83-105, 2017.

WOOD, D. J.; ENDICCOT, J. A. Structural insights into the functional diversity of the CDK - cyclin family. Open Biology, London, v. 8, n. 9, p.180112, 2018.

XIANG, J.; LAHTI, J. M.; GRENET, J.; EASTON, J.; KIDD, V. J. Molecular cloning and expression of alternatively spliced PITSLRE protein kinase isoforms. Journal of Biological Chemistry, New York, v. 269, n. 22, p. 15786-15794, 1994.

ZHANG, Y.; YIN, S.; ZHANG, B.; BI, J.; LIU, Y.; SU, Z. HBc-based virus-like particle assembly from inclusion bodies using 2-methyl-2, 4-pentanediol. Process Biochemistry, London, v. 89, p. 233-237, 2020.

ZHOU, Y.; HAN, C.; LI, D.; YU, Z.; LI, F.; AN, Q.; BAI, H.; ZHANG, X.; DUAN, Z.; KAN, Q. Cyclin-dependent kinase 11p110 (CDK11p110) is crucial for human breast cancer cell proliferation and growth. Scientific Reports, London, v. 5, n. 1, p. 10433, 2015 .

ZONG, H.; CHI, Y.; WANG, Y.; YANG, Y.; ZHANG, L.; CHEN, H.; JIANG, J.; LI, Z.; HONG, Y.; WANG, H.; YUN, X.; GU, J. Cyclin D3/CDK11p58 complex is involved in the repression of androgen receptor. Molecular and Cellular Biology, Washington, v. 27, n. 20, p. 7125-7142, 2007. 
ANEXO 1 - Alinhamento das 20 isoformas da CDK11, realizado utilizando a ferramenta online MultAlin. Em azul e vermelho destaca-se os aminoácidos conservados.
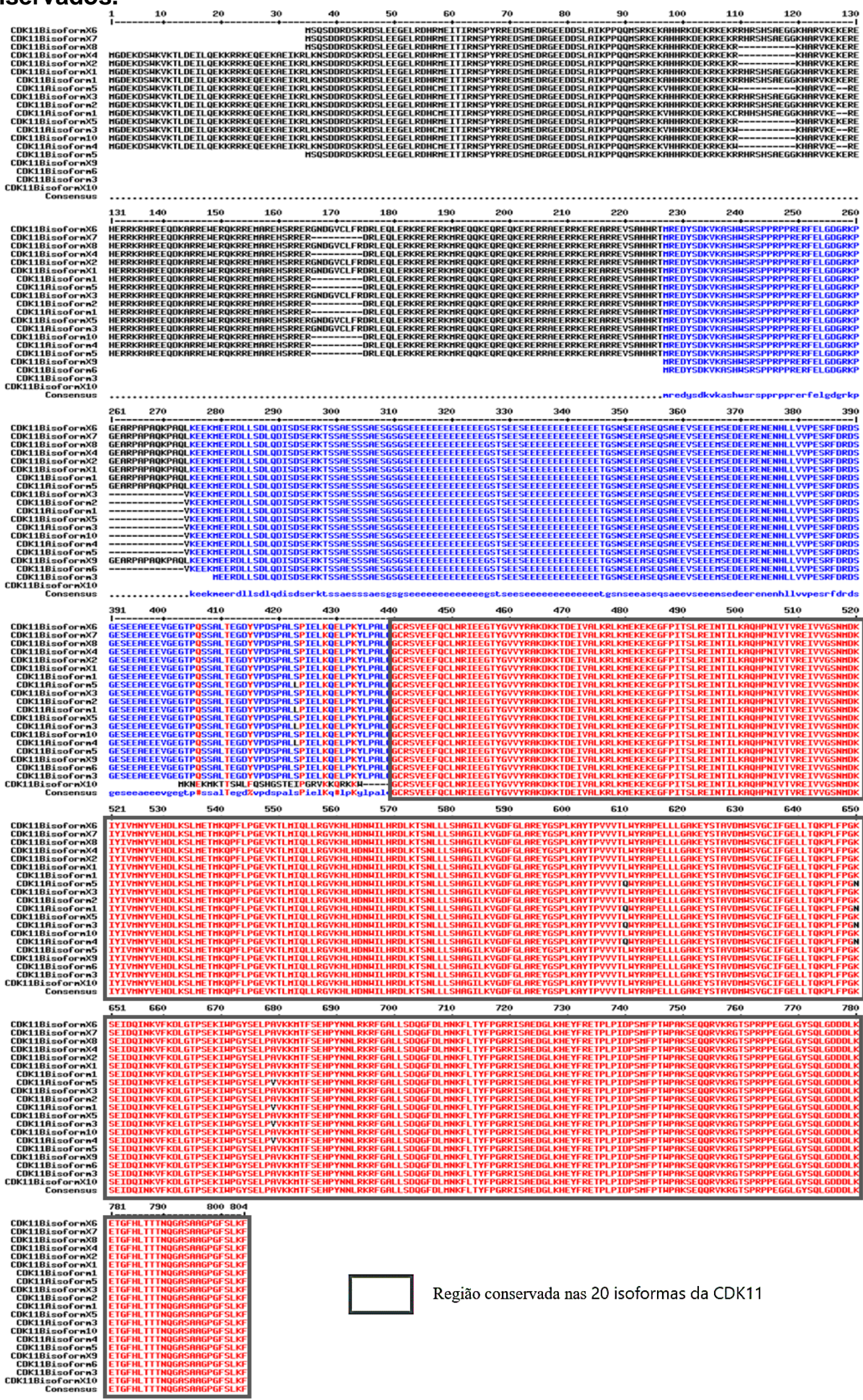

Região conservada nas 20 isoformas da CDK11

Fonte: Autoria Própria. 
ANEXO 2 - Alinhamento da CDK2 com a CDK11, realizado utilizando a ferramenta online ESPript. Em caixas azuis destacam-se as estruturas secundárias e em caixas vermelhas os aminoácidos conservados

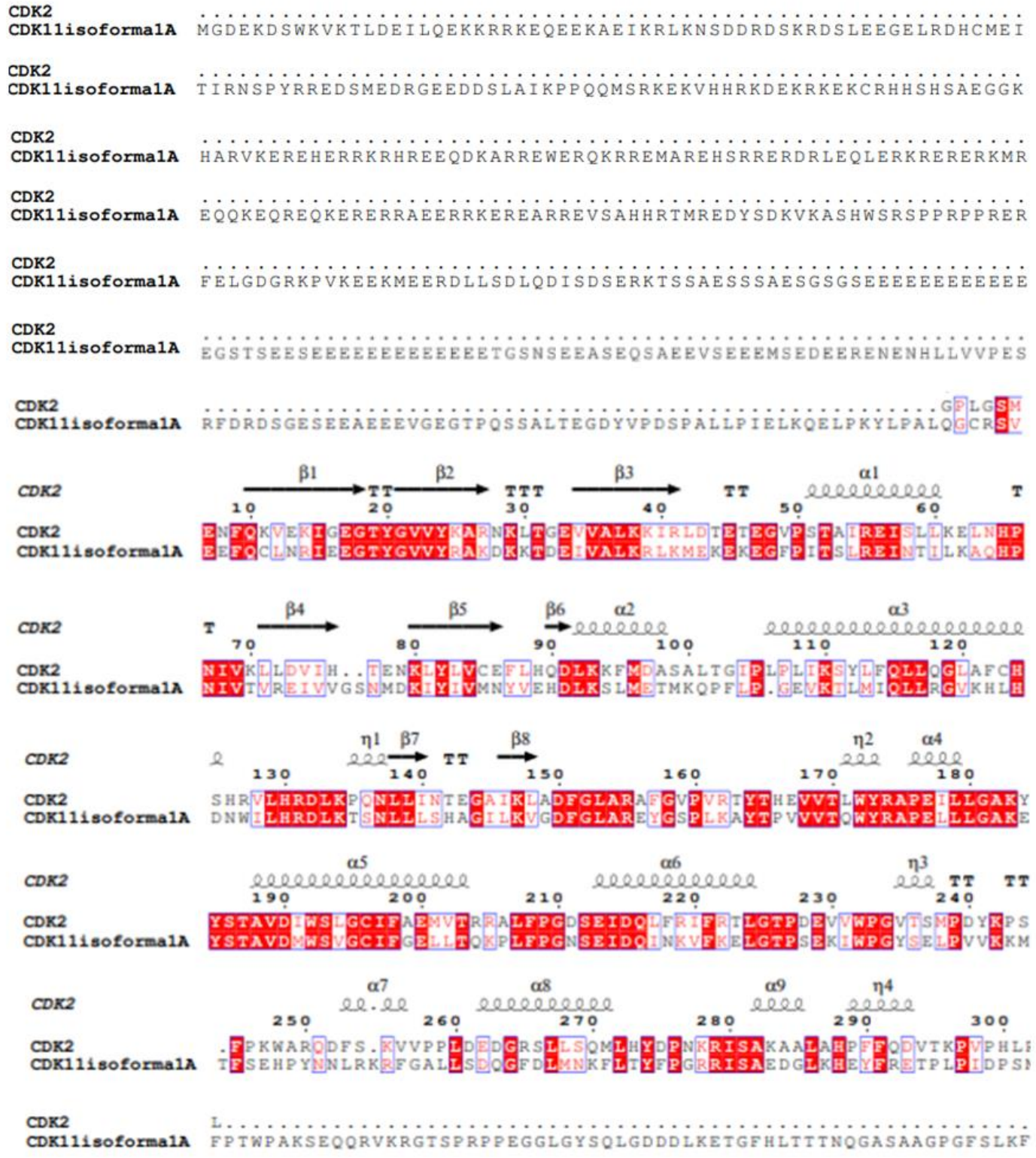

CDK2$$
\alpha 7
$$$$
250
$$$$
260 \frac{26 e c e l o l}{270}
$$$$
\text { ele }
$$$$
2020
$$

CDK2

CDK11isoforma1A

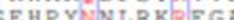

$\operatorname{CDK} 2$

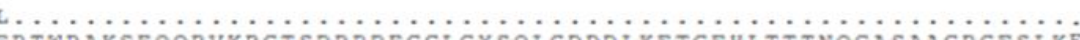

CDK111soforma1A FPTWPAKSEQQRVKRGTSPRPPEGGLGSQLGDDLKETGEHLTTTNQGASAAGPGESLKF

Fonte: Autoria Própria. 
ANEXO 3 - Géis de agarose para as diferentes condições testadas, conforme Tabela 3, relatada na metodologia. Em vermelho destacada à amplificação da CDK11 $\Delta$.

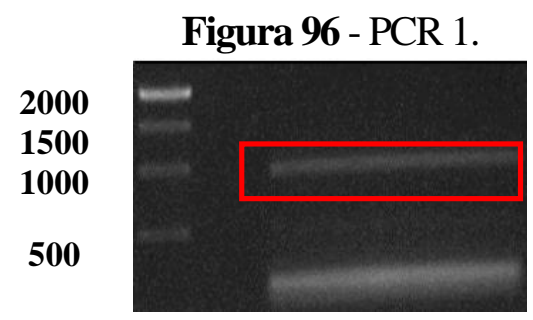

Fonte: Autoria própria.

Figura 97 - PCR 2.

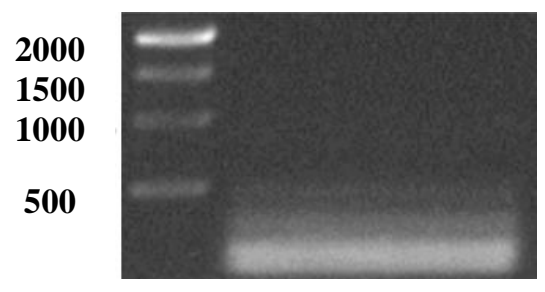

Fonte: Autoria própria.

Figura 98 - PCR 3.

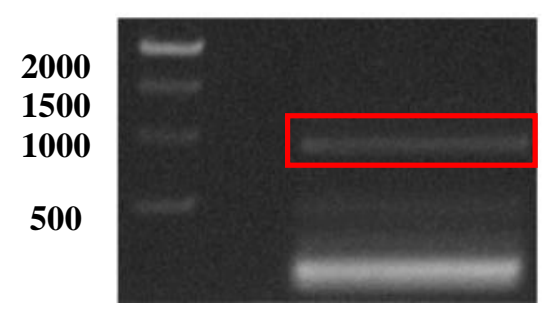

Fonte: Autoria própria.

Figura 99 - PCRs 4 a 10.

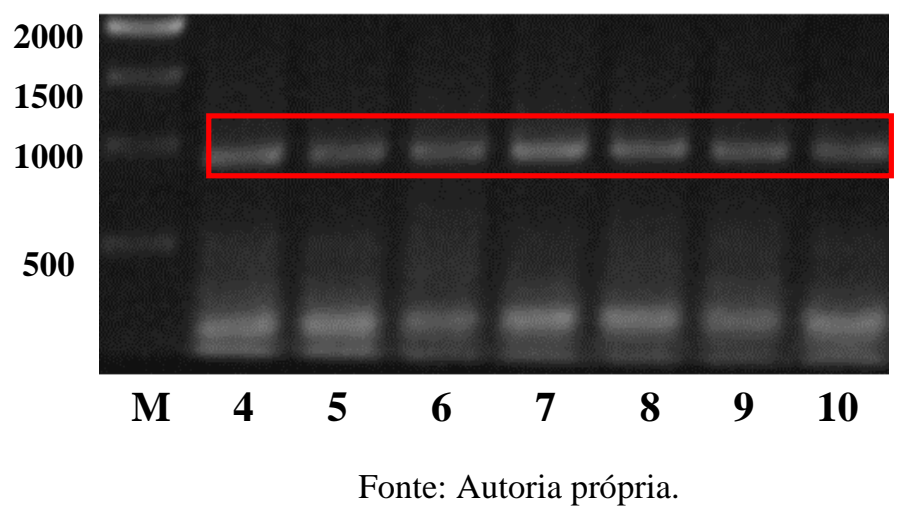


ANEXO 4 - Géis de eletroforese da expressão usando o protocolo de LEOPOLDINO et al. (2006).

Figura 100 - Gel de eletroforese da expressão a $30^{\circ} \mathrm{C}$ da CDK11 $\Delta$. Em que $\mathrm{M}$ - marcador; $2 \mathrm{~s}$ sobrenadante após 2 horas, $2 \mathrm{p}$ - pellet após 2 horas, $6 \mathrm{~s}$ - sobrenadante após 6 horas, $6 \mathrm{p}$ - pellet após 6 horas $22 \mathrm{~s}$ - sobrenadante após 22 horas, $22 \mathrm{p}$ - pellet após 22 horas.

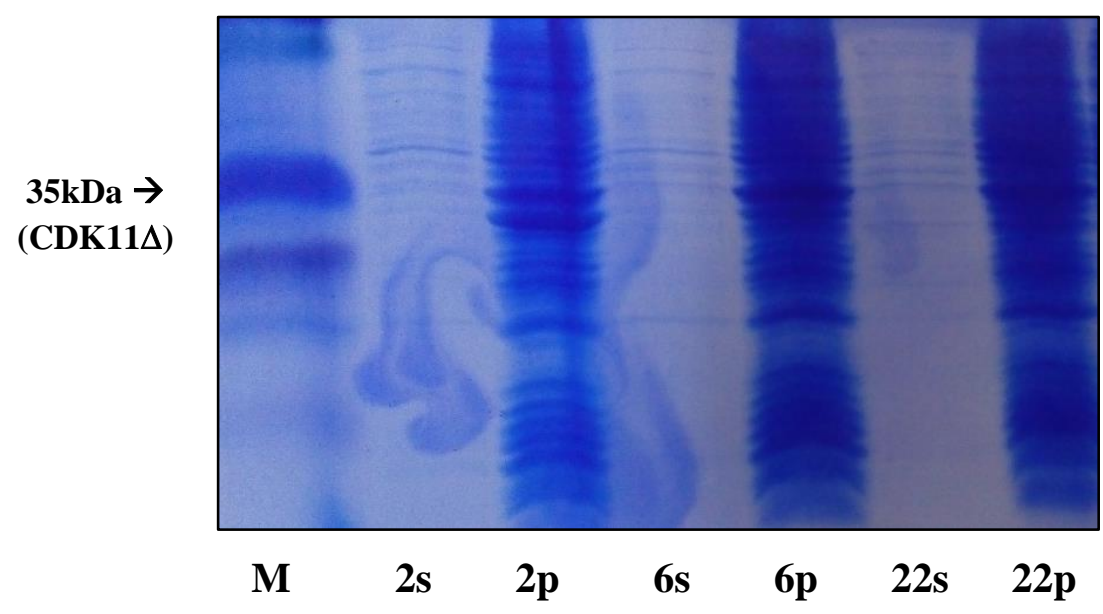

Fonte: Autoria própria.

Figura 101 - Gel de eletroforese da expressão a $18^{\circ} \mathrm{C}$ da CDK11 $\triangle$. Em que M - marcador; $2 \mathrm{~s}$ sobrenadante após 2 horas, $2 \mathrm{p}$ - pellet após 2 horas, $6 \mathrm{~s}$ - sobrenadante após 6 horas, $6 \mathrm{p}$ - pellet após 6 horas $22 \mathrm{~s}$ - sobrenadante após 22 horas, $22 \mathrm{p}$ - pellet após 22 horas.

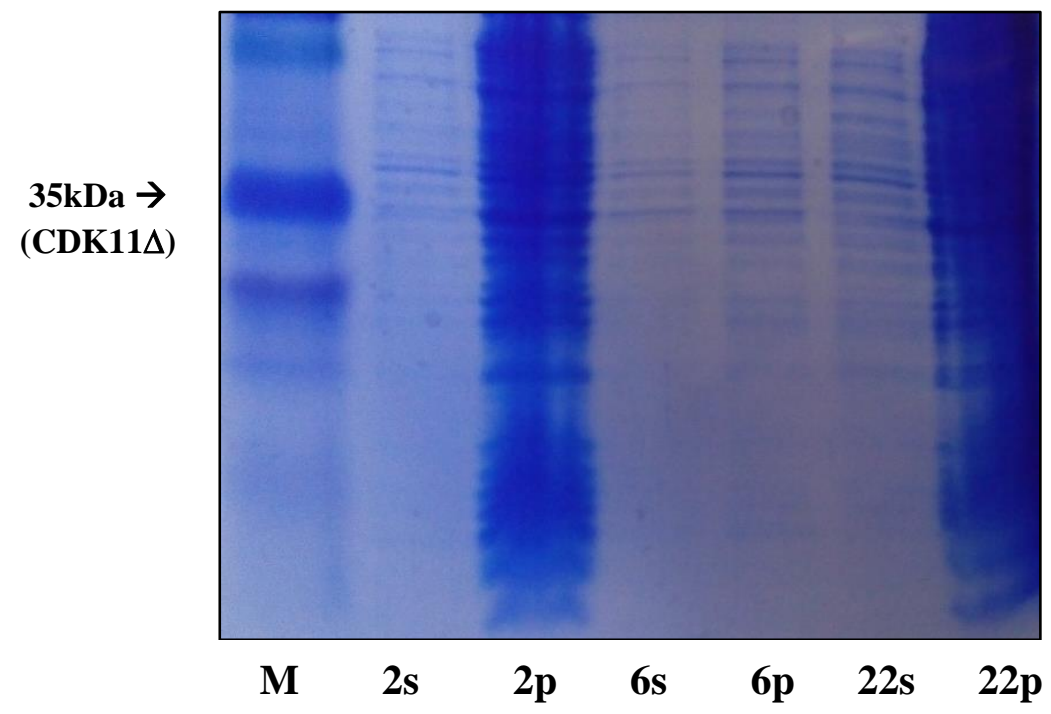

Fonte: Autoria própria. 
ANEXO 5 - Géis de eletroforese da expressão segundo Tabela 7 , relatada na metodologia, para otimização da expressão e reenovelamento da CDK11 $\Delta$.

Figura 102 - Gel de eletroforese da expressão 1 , a $37^{\circ} \mathrm{C}$ da CDK11 $\triangle$. Em que M - marcador; 0s sobrenadante após 0 horas, $0 \mathrm{p}$ - pellet após 0 horas, $3 \mathrm{~s}$ - sobrenadante após 3 horas, $3 \mathrm{p}$ - pellet após 3 horas, $7 \mathrm{~s}$ - sobrenadante após 7 horas, $7 \mathrm{p}$ - pellet após 7 horas.

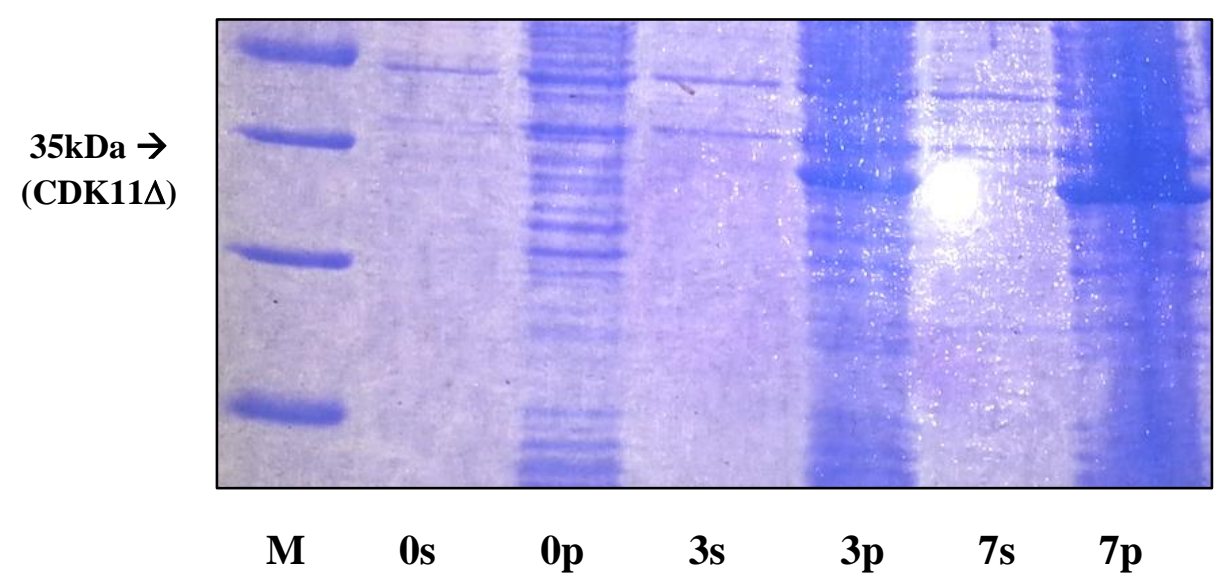

Fonte: Autoria própria.

Figura 103 - Gel de eletroforese da expressão 2, a $37^{\circ} \mathrm{C}$ da CDK11 $\triangle$. Em que M - marcador; 0s sobrenadante após 0 horas, $0 \mathrm{p}$ - pellet após 0 horas, $3 \mathrm{~s}$ - sobrenadante após 3 horas e sonicação, $3 p$ - pellet após 3 horas e sonicação.

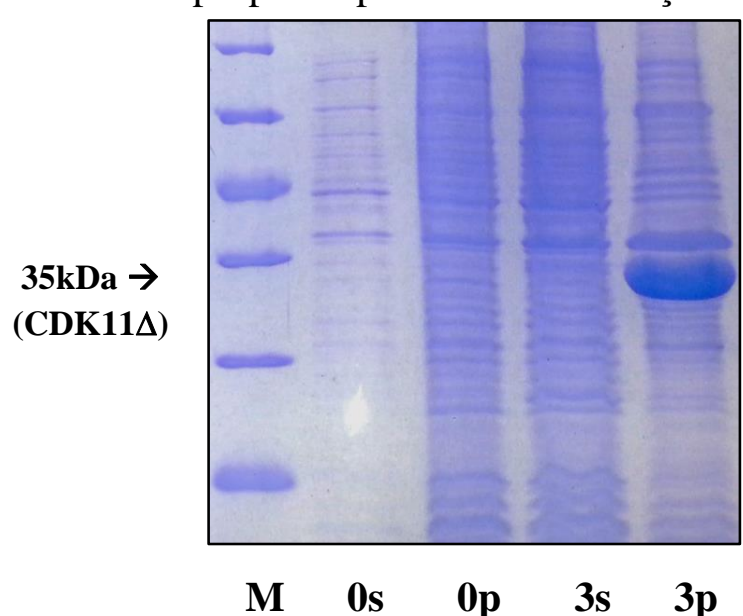

Fonte: Autoria própria. 
Figura 104 - Gel de eletroforese da expressão 3, a $37^{\circ} \mathrm{C}$ da CDK11 $\Delta$. Em que M - marcador; SDSs- sobrenadante após solubilização de SDS sem sonicação e SDSs*- sobrenadante após solubilização de SDS com sonicação.

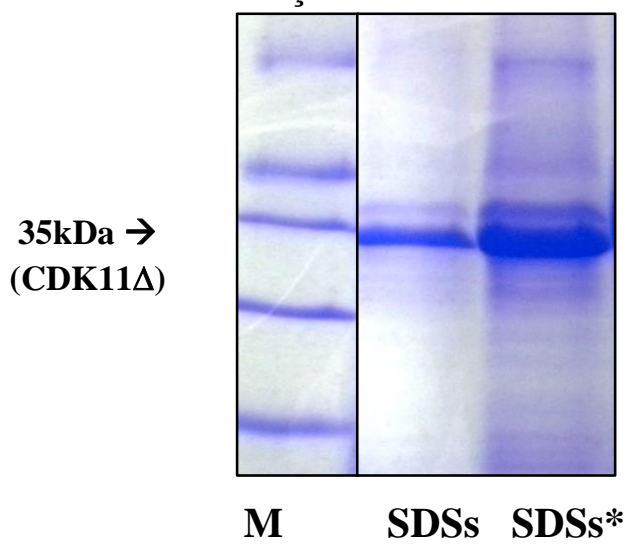

Fonte: Autoria própria.

Figura 105 - Gel de eletroforese da expressão 4, a $37^{\circ} \mathrm{C}$ da CDK11 $\triangle$. Em que M - marcador; 0s sobrenadante após 0 horas, $0 \mathrm{p}$ - pellet após 0 horas, $3 \mathrm{~s}$ - sobrenadante após 3 horas e sonicação, $3 p$ - pellet após 3 horas e sonicação,SDSs- sobrenadante após solubilização de SDS e centrifugação, SDSp- pellet após solubilização de SDS e centrifugação KCls- sobrenadante após utilização de $\mathrm{KCl}$ e centrifugação e KClp- pellet após utilização de $\mathrm{KCl}$ e centrifugação.

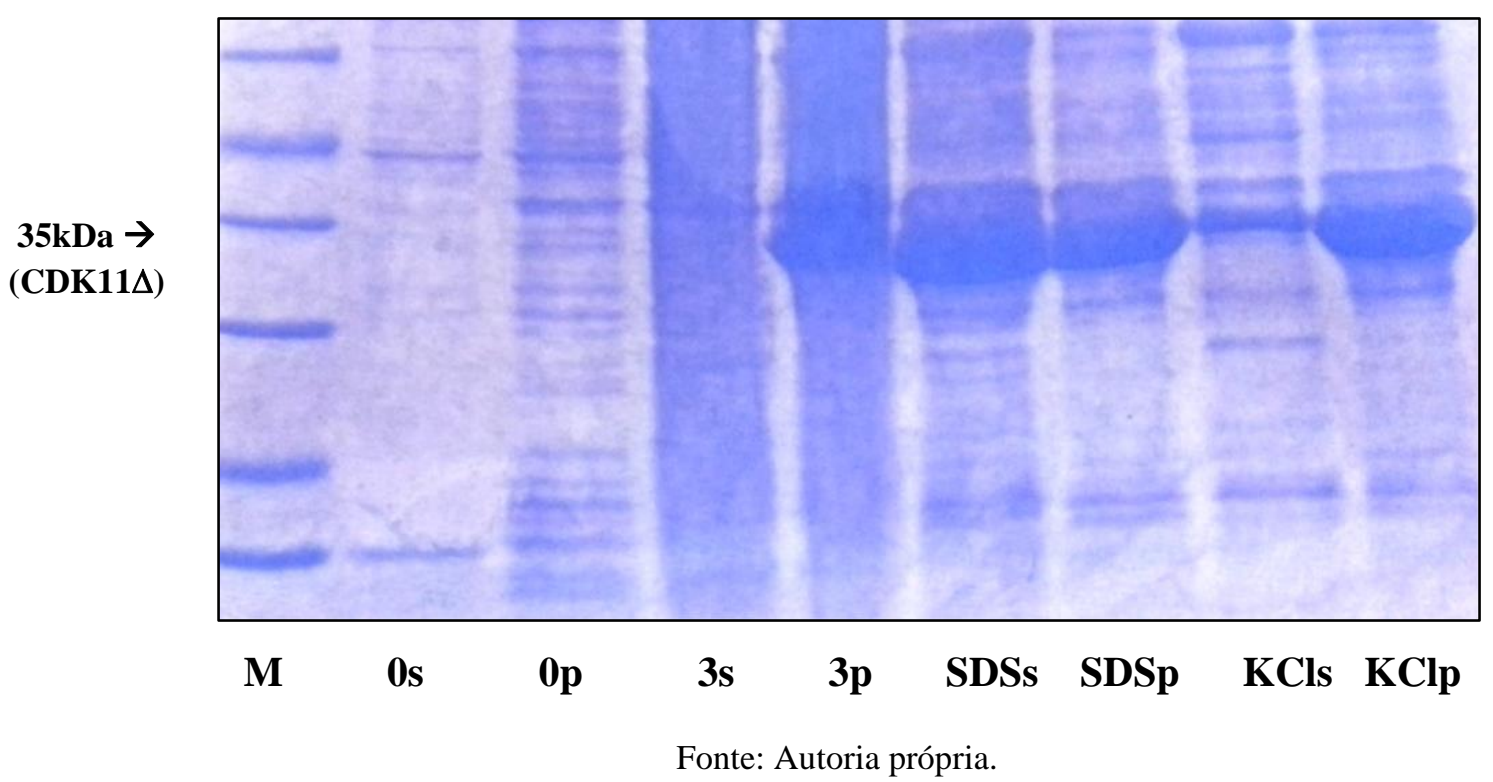


Figura 106 - Gel de eletroforese da expressão 5, a $37^{\circ} \mathrm{C}$ da CDK11 $\triangle$. Em que M - marcador; 0s sobrenadante após 0 horas, $0 \mathrm{p}$ - pellet após 0 horas, $3 \mathrm{~s}$ - sobrenadante após 3 horas e sonicação, $3 \mathrm{p}$ - pellet após 3 horas e sonicação, 86s- sobrenadante após solubilização de SDS e centrifugação a 8600rpm, 86p- pellet após solubilização de SDS e centrifugação a 8600rpm 110s- sobrenadante após solubilização de SDS e centrifugação a 11000rpm, 110p- pellet após solubilização de SDS e centrifugação a 11000rpm.

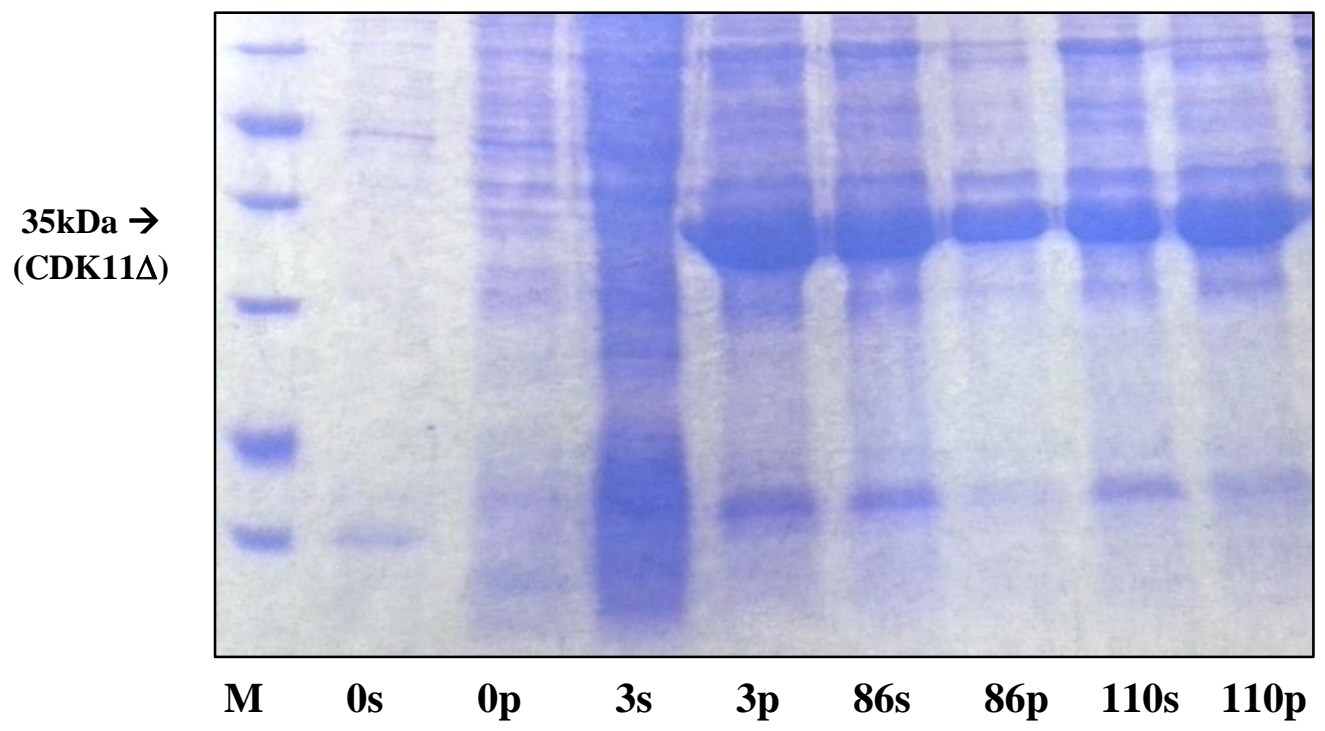

Fonte: Autoria própria.

Figura 107 - Gel de eletroforese da expressão 6, a $37^{\circ} \mathrm{C}$ da CDK11 $\Delta$. Em que M - marcador; 0s sobrenadante após 0 horas, $0 \mathrm{p}$ - pellet após 0 horas, $5 \mathrm{~s}$ - sobrenadante após 5 horas e sonicação, $5 \mathrm{p}$ - pellet após 5 horas e sonicação, SDSs- sobrenadante após solubilização de SDS e centrifugação, SDSp - pellet após solubilização de SDS e centrifugação.

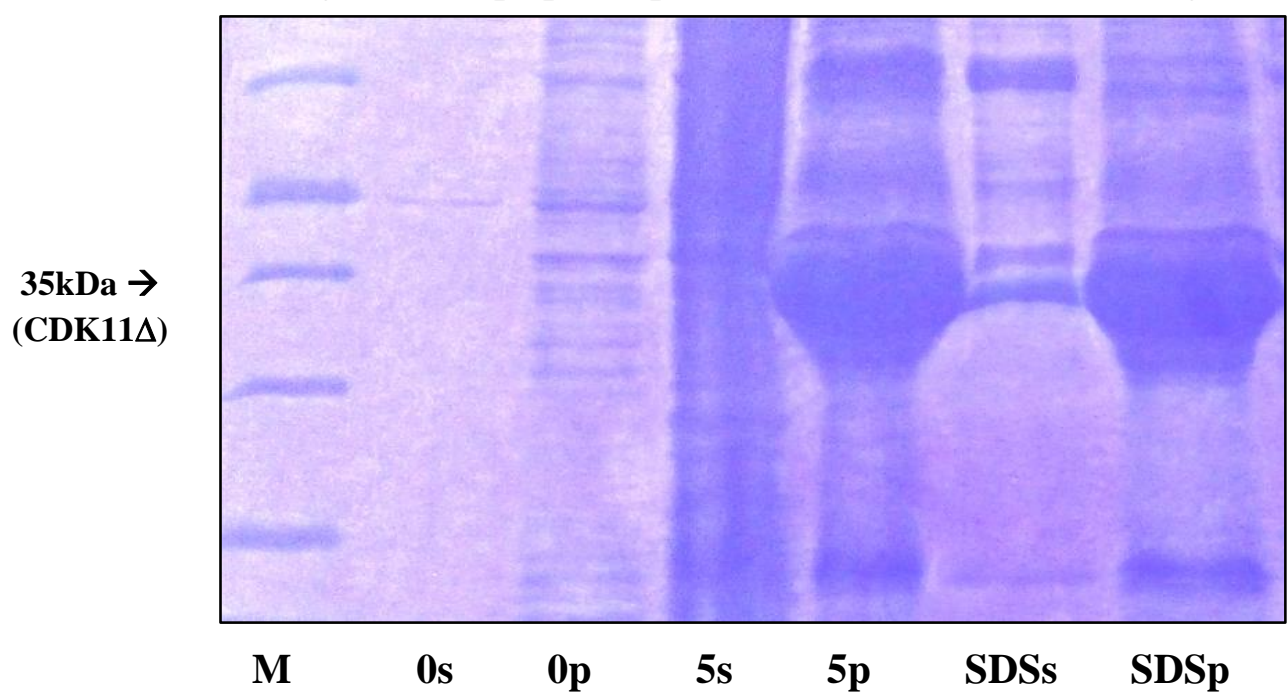

Fonte: Autoria própria. 
Figura 108 - Gel de eletroforese da expressão 7, a $37^{\circ} \mathrm{C}$ da CDK11 $\triangle$. Em que M - marcador; 0s sobrenadante após 0 horas, $0 \mathrm{p}$ - pellet após 0 horas, $5 \mathrm{~s}$ - sobrenadante após 5 horas e sonicação, $5 p$ - pellet após 5 horas e sonicação, SDSs- sobrenadante após solubilização de SDS e centrifugação, SDSp - pellet após solubilização de SDS e centrifugação, L - lavagem do pellet

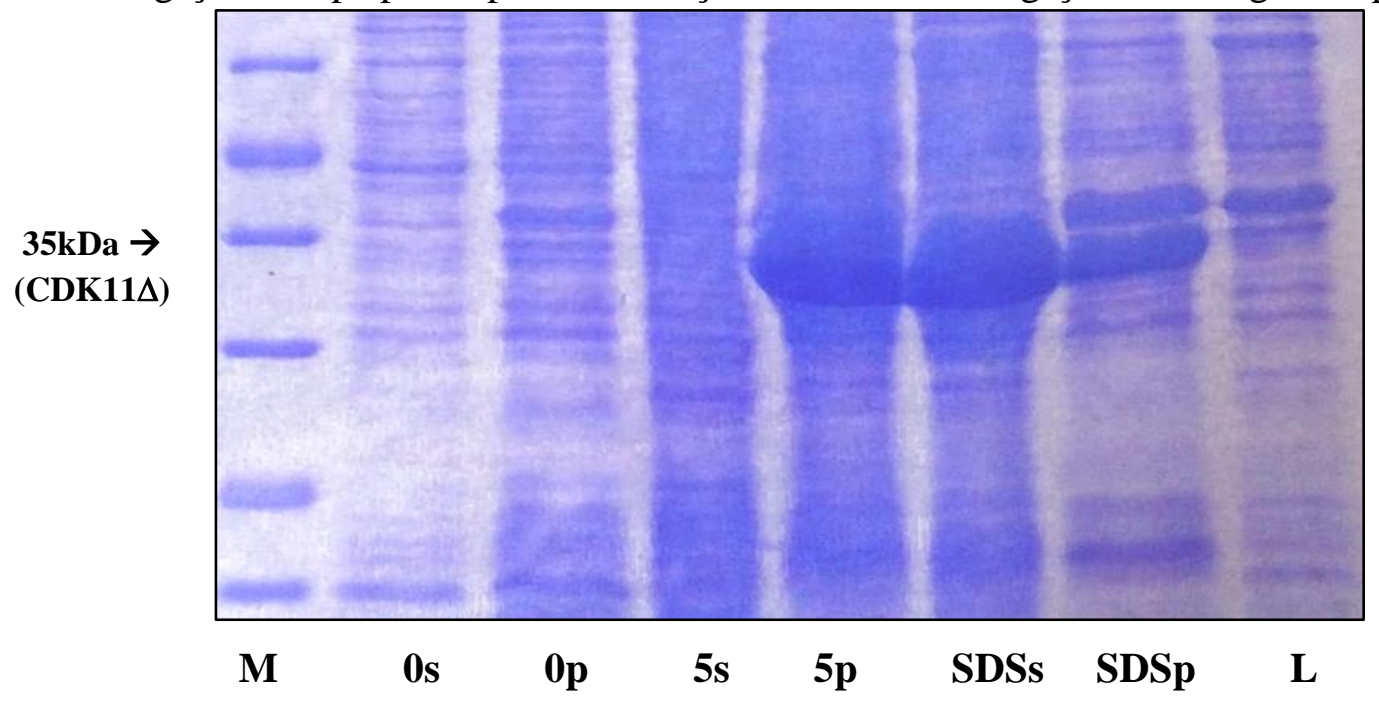

Fonte: Autoria própria.

Figura 109 - Gel de eletroforese da expressão 7, a $37^{\circ} \mathrm{C}$ da CDK11 $\triangle$. Em que $\mathrm{M}$ - marcador e os demais são as amostras após purificação por coluna de afinidade ao níquel, sendo 5 a 8 - os picos do cromatograma das impurezas e de 60 a 64 - os picos do cromatograma relativos a proteína de interesse.

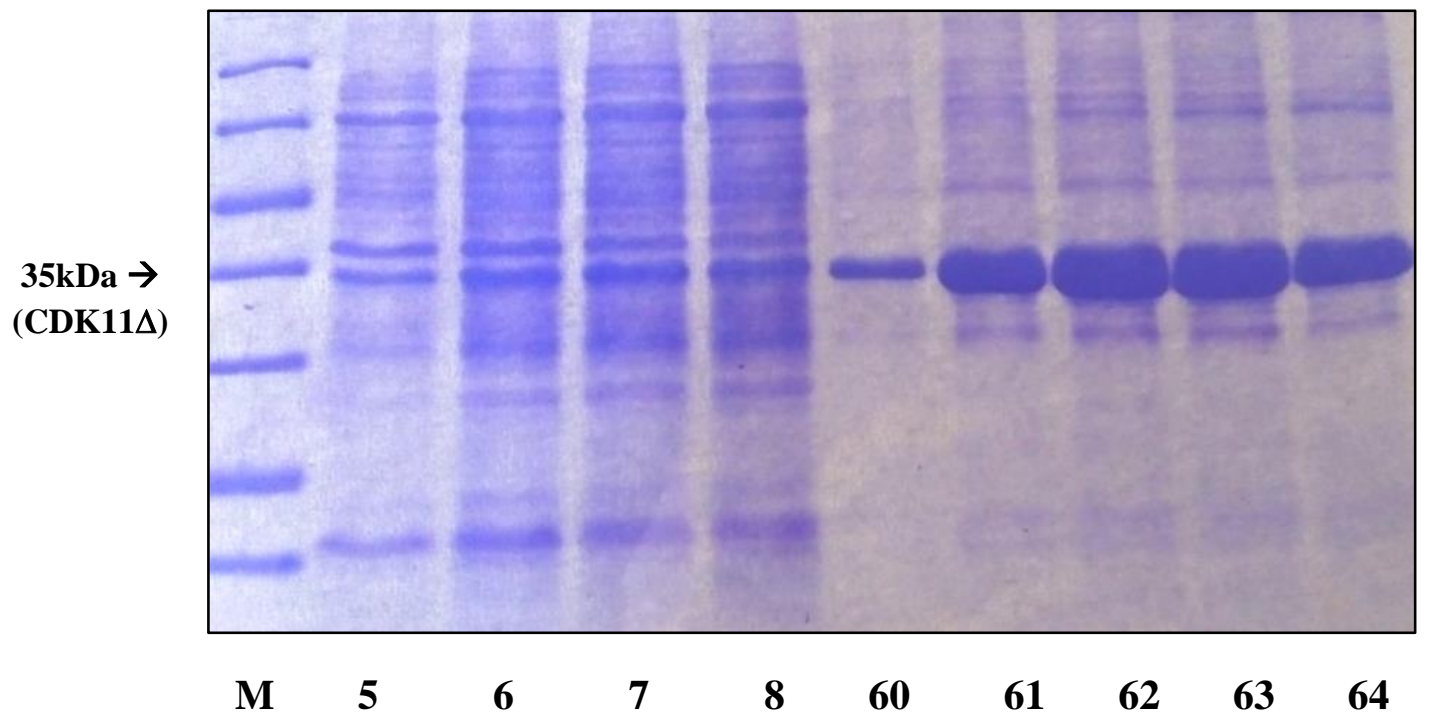

Fonte: Autoria própria. 
Figura 110 - Gel de eletroforese da expressão 8, a $37^{\circ} \mathrm{C}$ da CDK11 $\triangle$. Em que M - marcador; $5 \mathrm{~s}$ sobrenadante após 5 horas e sonicação, $5 \mathrm{p}$ - pellet após 5 horas e sonicação, SDSs- sobrenadante após solubilização de SDS e centrifugação, SDSp - pellet após solubilização de SDS e

centrifugação, $\mathrm{L}$ - lavagem do pellet, 8 - um dos picos do cromatograma das impurezas, 64 - um dos picos do cromatograma relativo a proteína de interesse, AS - amostra antes da superdex, DS amostra depois da superdex.

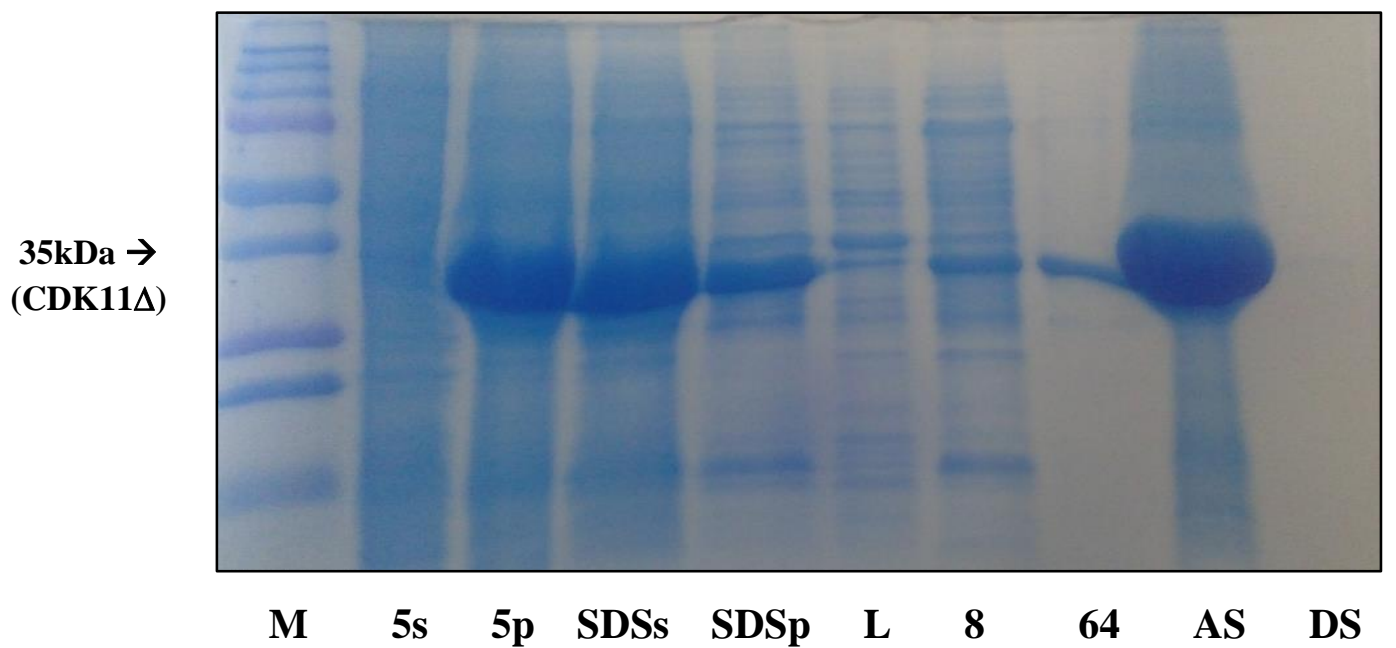

Fonte: Autoria própria.

Figura 111 - Gel de eletroforese da expressão 9, a $37^{\circ} \mathrm{C}$ da CDK11 $\Delta$. Em que M - marcador; L1 a L3 são as lavagens do pellet, 5p - pellet após 5 horas e sonicação, SDSs- sobrenadante após solubilização de SDS e centrifugação, I - impurezas depois da coluna de níquel, $\mathrm{P}$ - proteína $\mathrm{CDK} 11 \Delta$ depois da coluna de níquel.

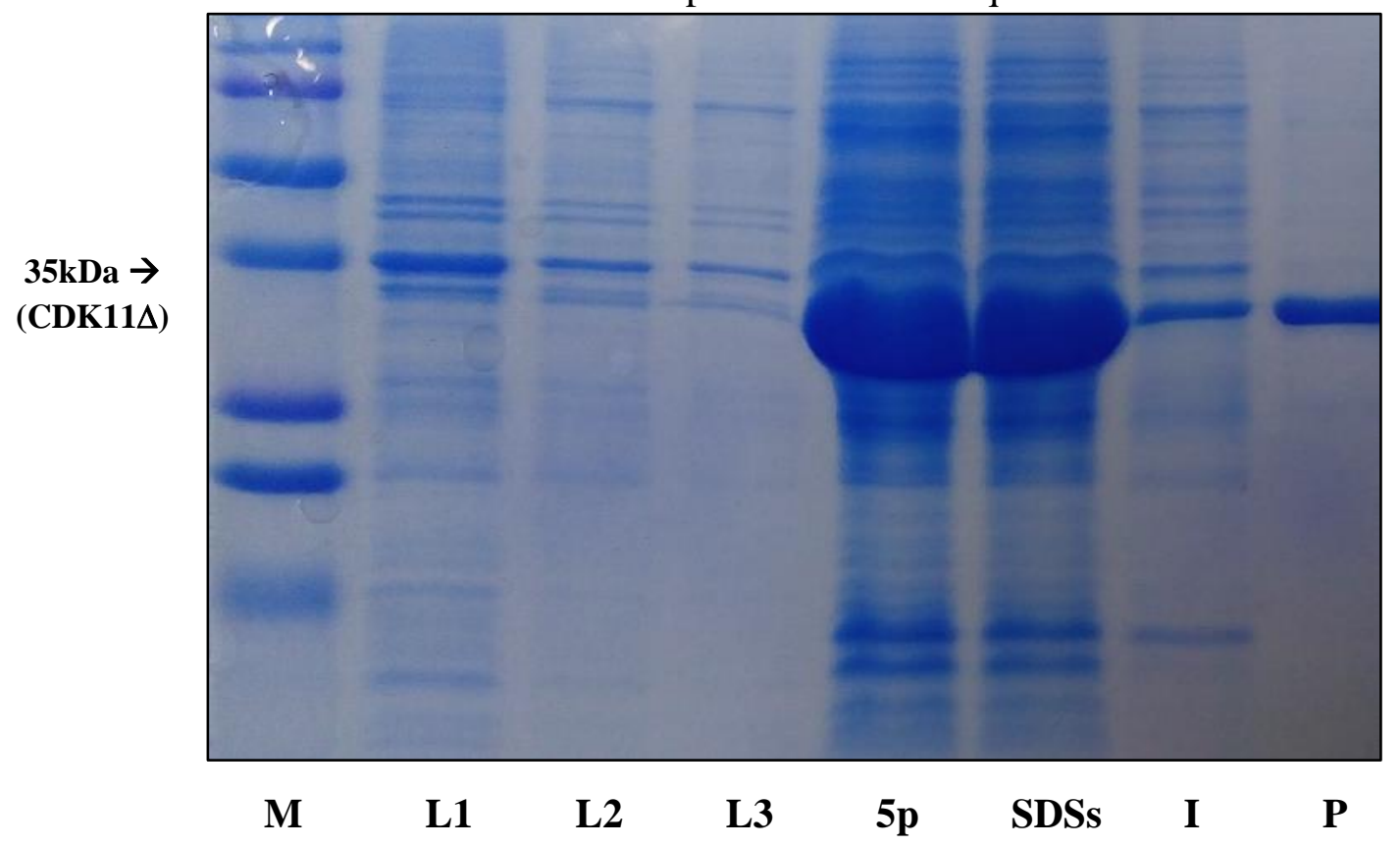

Fonte: Autoria própria. 
Figura 112 - Gel de eletroforese da expressão 10 , a $37^{\circ} \mathrm{C}$ da CDK11 $\Delta$. Em que M - marcador; 5s - sobrenadante após 5 horas e sonicação, L1 a L3 são as lavagens do pellet, $5 p$ - pellet após 5 horas e sonicação, SDSs- sobrenadante após solubilização de SDS e centrifugação, I - impurezas depois da coluna de níquel, $\mathrm{P}$ - proteína CDK11 $\Delta$ depois da coluna de níquel.

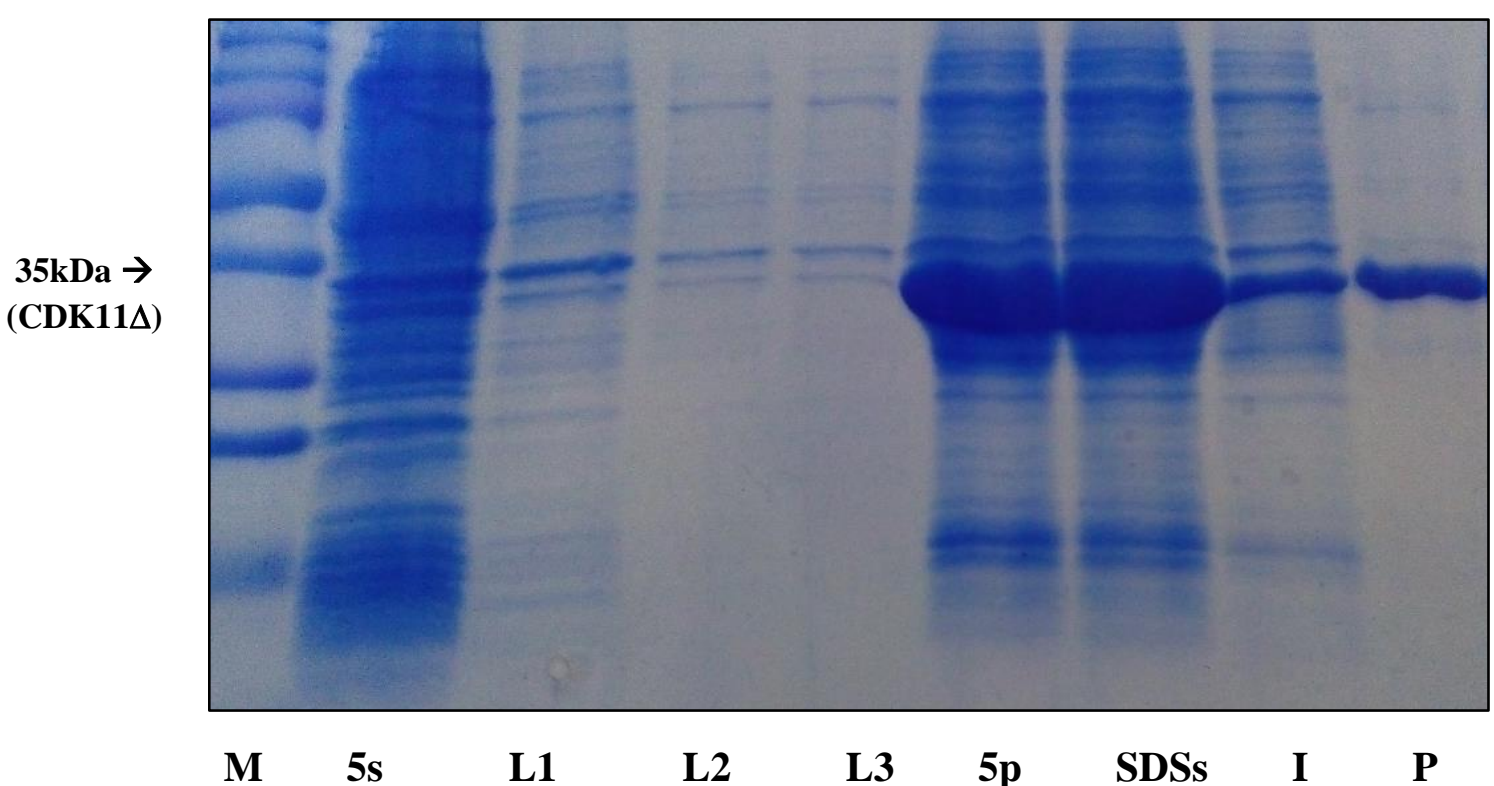

Fonte: Autoria própria.

Figura 113 - Gel de eletroforese da expressão 11 , a $37^{\circ} \mathrm{C}$ da $\mathrm{CDK} 11 \Delta$. Em que M - marcador; $5 \mathrm{~s}$ - sobrenadante após 5 horas e sonicação, L1 a L3 são as lavagens do pellet, 5p - pellet após 5 horas e sonicação, SDSs- sobrenadante após solubilização de SDS e centrifugação, I - impurezas depois da coluna de níquel, $\mathrm{P}$ - proteína $\mathrm{CDK} 11 \Delta$ depois da coluna de níquel.

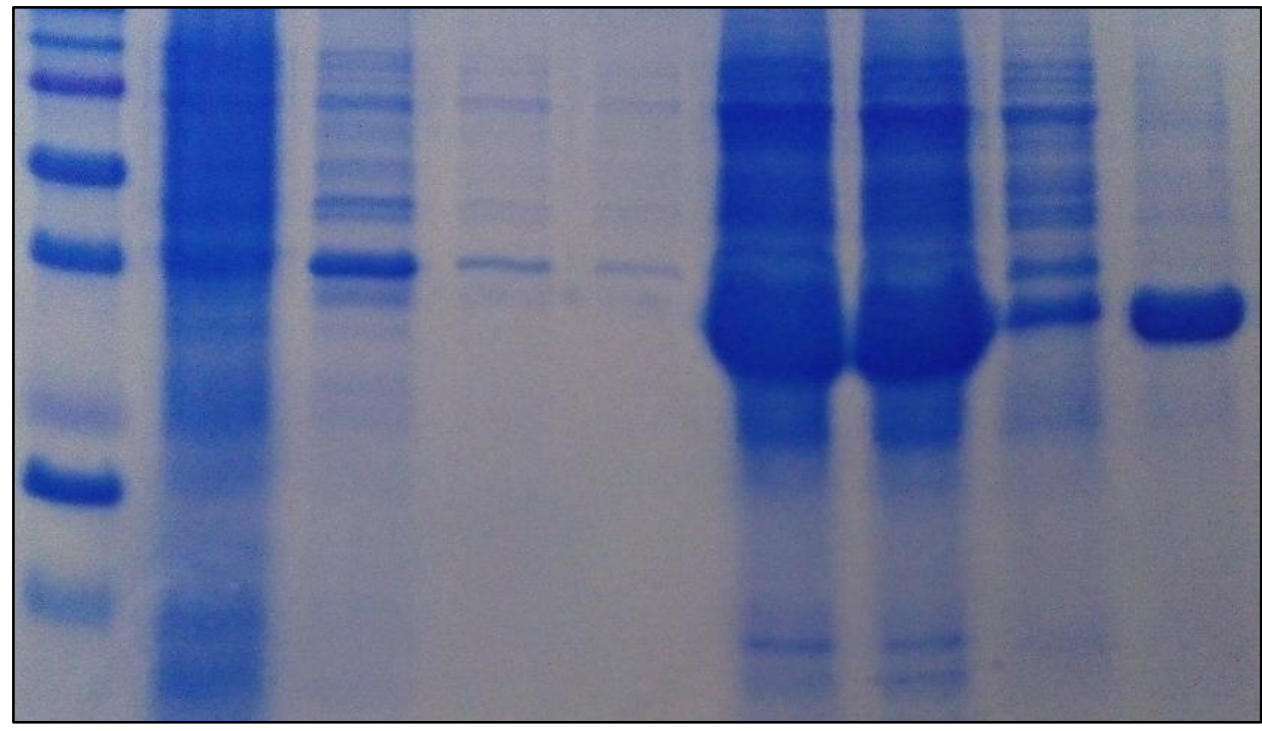

$\begin{array}{lllllllll}\text { M } & \text { 5s } & \text { L1 } & \text { L2 } & \text { L3 } & \text { 5p } & \text { SDSs } & \text { I } & \text { P }\end{array}$

Fonte: Autoria própria. 